Canadian Settlement in Action: History and Future 



\section{Canadian Settlement in Action: History and Future}

ALEXANDRU CALDARARU; JULIE CLEMENTS; RENNAIS GAYLE; CHRISTINA HAMER; MARIA MACMINN VARVOS; AND LYNN SUTANKAYO 


\section{(c) (i) (2) (2)}

Canadian Settlement in Action: History and Future by NorQuest College is licensed under a Creative

Commons Attribution-NonCommercial-ShareAlike 4.0 International License, except where otherwise noted. 


\section{Contents}

Copyright $\quad$ xiii

Acknowledgement xiv

Foreword $\quad$ xvi

Chapter r: The History of Settlement Services in Canada

Introduction

Maria MacMinn Varvos

Key Terms

Settlement Services

$\begin{array}{ll}\text { Introduction to Settlement and Immigration in Canada } & 7\end{array}$

Restoring a Declining Population: The Impetus for Immigration in Canada 8

Canada: New Exploration Leads to New Directions 11

Canada's Immigration History: Milestones and Stories 14

Milestone 1: Immigrants Build the Foundation and Infrastructure of Canada 17

$\begin{array}{ll}\text { Stories of Acceptance and Rejection } & 19\end{array}$

Milestone 2: Post-War Immigration Challenges 22

Milestone 3: Canada's Evolving Immigration Policy 27

Settlement and Integration $\quad 35$

History of Settlement Services in Canada Glossary Terms Flashcards 35

Essential Steps Upon Arrival to Canada 36

The Role of Immigrant Settlement Services 38

Evolution of Settlement Support Services 41

Additional Resources $\quad 44$

Settlement Services Delivery Models: What Works $\quad 45$

Overview of Settlement Service Providers in Canada 46

Additional Resources 52 
Immigrant and Refugee Historical Settlement Needs 53

Understanding Your Client Group: Immigrant Stories 53

$\begin{array}{ll}\text { Additional Suggested Resources } & 60\end{array}$

Perspectives on the Value of Settlement Services 61

Non-Profit Organizations that Support Settlement Sector Practitioners 64

Principles and Values of the Sector 65

$\begin{array}{ll}\text { Conclusion } & 67\end{array}$

$\begin{array}{ll}\text { Chapter References and Attributions } & 69\end{array}$

$\begin{array}{ll}\text { References } & 69\end{array}$

$\begin{array}{ll}\text { Media Attributions } & 73\end{array}$

Chapter 2: Social Justice in Settlement Work

Introduction $\quad 77$

Alexandru Caldararu

$\begin{array}{lr}\text { Multiculturalism and Myth-Making in Canada } & 80\end{array}$

I. The Great American (Meritocratic) Myth 80

II. The Great Canadian (Multicultural) Myth 81

82

III. Historical Anti-Immigrant Sentiment 82

Oppression, Anti-Oppression, and Social Justice $\quad 99$

I. Hegemony, "Common Sense," and Canadian Exceptionalism 99

II. The "Disorienting" of Canadian Exceptionalism 101

III. Anti-Oppressive Practice and Further "Disorientations" 104

IV. Allyship and Social Justice 112

$\begin{array}{ll}\text { Conclusion } & 117\end{array}$

$\begin{array}{ll}\text { Chapter References and Attributions } & 119\end{array}$

$\begin{array}{ll}\text { References } & 119\end{array}$

$\begin{array}{ll}\text { Media Attributions } & 134\end{array}$ 
Chapter 3: Migration-Related Trauma and Refugee Mental Health in the Canadian Resettlement Sector

Overview

Christina Hamer

Key Terms

Introduction

$\begin{array}{ll}\text { Migration-Related Trauma } & 147\end{array}$

What is Migration-Related Trauma? 147

Determinants of Migrant Mental Health 149

Resilience and the "Resilient Migrant" 151

$\begin{array}{ll}\text { Forced Migration } & 156\end{array}$

Drivers of (Forced) Migration 156

Cases to Consider 159

Canadian Immigration Programs for Vulnerable Migrants with High 164

Support Needs

Asylum Seekers and Refugee Claimants 164

Resettled Refugees 165

Stakeholders in Private Sponsorship 166

Challenges for Newcomers in Accessing Mental Health Supports and the 169

Canadian Health System, and Good and Promising Practices Across

Canada

Importance of the Post-Migration Period and Trauma 169

Specific Challenges in Accessing Health Care and Mental Health Services $\quad 170$

$\begin{array}{ll}\text { Conclusion } & 178\end{array}$

$\begin{array}{ll}\text { Summary } & 178\end{array}$

$\begin{array}{ll}\text { Optional Readings and Resources } & 180\end{array}$

Chapter References and Attributions 181

References 181

$\begin{array}{ll}\text { Media Attributions } & 187\end{array}$ 


\section{Chapter 4: Family Dynamics - Working with Seniors}

Introduction

Rennais Gayle

Key Terms

Settlement Experiences of Seniors Coming to Canada 196

Theories of Late-Life Migration and Communication Accommodation

Theory

Evaluating Client Need

Elder Abuse

Elder Abuse and Neglect

Summary 218

Chapter Learning Activities $\quad 220$

Reflective Task Rubric 223

Learning Activity 8: Cross-Cultural Intercultural Communication in

Settlement Situations

Learning Activity 9: Communication Accommodation Theory in Action

Problem Solving Through Case Studies

Case Study 1: Awek's Health Dilemma

Case Study 2: Adult Child and Elder Parent Conflict 230

Case Study 3: Isolation 232

Case Study 4: Grandparent Challenges 233

Case Study 5: Trauma and Resettlement 234

Key Terms and Definitions 236

Conclusion 237

Optional Readings and Resources 238

Chapter References and Attributions 240

References 240

Media Attributions 243 
Introduction

Julie Clements

Overview

Key Terms

What is Culture and Intercultural Competence?

What is Culture?

What is Intercultural Competence?

Improving Intercultural Competence 265

How We Experience Cultural Difference 265

Using Intercultural Tools to Interpret Miscommunications 268

Expanding Cultural Knowledge with Culture General Frameworks 272

A Process Model for Improving Our Intercultural Competence 281

Making an Intercultural Competence Development Action Plan 282

Supporting Clients to Develop Intercultural Competence 284

Review Activities - DMIS Stages 285

$\begin{array}{ll}\text { Summary } & 288\end{array}$

$\begin{array}{ll}\text { Optional Readings and Resources } & 289\end{array}$

$\begin{array}{ll}\text { Optional Readings } & 289\end{array}$

Further Tools for Assessing Intercultural Competence and Communication 289

$\begin{array}{ll}\text { Websites } & 290\end{array}$

Chapter References and Attributions 291

$\begin{array}{ll}\text { References } & 291\end{array}$

$\begin{array}{ll}\text { Media Attributions } & 292\end{array}$

Chapter 6: Gender, Sexuality, and Culture

$\begin{array}{ll}\text { Introduction } & 295\end{array}$

Lynn Sutankayo

$\begin{array}{ll}\text { Situating Ourselves } & 295\end{array}$

$\begin{array}{ll}\text { Key Terms } & 297\end{array}$

$\begin{array}{ll}\text { Guiding Questions } & 300\end{array}$

Gender, Equality, and Justice $\quad 304$

Gender Equality and Gender Equity 305 
Measuring Gender Equality

Gender Equality - A Global Goal 308

$\begin{array}{ll}\text { Campaigning for Gender Equality } & 310\end{array}$

Mapping Sexual-Orientation Laws 311

Canada's Gender and Immigrant Pay Gaps 314

Gender 316

$\begin{array}{ll}\text { Further Reading } & 319\end{array}$

$\begin{array}{ll}\text { Gender Roles } & 320\end{array}$

Gender Stereotypes 322

Gender-Based Analysis Plus $\quad 326$

Chapter References and Attributions 328

$\begin{array}{ll}\text { References } & 328\end{array}$

Chapter 7: How Literacy Affects the Settlement of Immigrant Women

$\begin{array}{ll}\text { Introduction } & 337\end{array}$

Maria MacMinn Varvos

Introduction to Chapter Study 338

Tips for Navigating this Chapter 339

Adult Literacy, Life Skills, and Settlement 340

Lack of Education Does Not Equal Lack of Ability 341

Literacy - What is it? How does it fit into the settlement process? 342

The Causes of Low Literacy for Immigrant Women 348

$\begin{array}{ll}\text { Health Literacy } & 349\end{array}$

Strengths of Low-Literacy Adults 351

How Immigrant Women with Low Literacy Navigate the Literate English- 351

Speaking World

LFLL Immigrant Woman's Story 1

LFLL Immigrant Woman's Story 2

$\begin{array}{ll}\text { Activity } & 355\end{array}$

$\begin{array}{ll}\text { Reflection } & 355\end{array}$ 
The Relationship Between First-Language Literacy and the Settlement and Integration Challenges Faced by Immigrant Women

Lack of Opportunity, Not Lack of Ability

358

Effects of War on Immigration $\quad 360$

How does low first-language literacy affect immigrant women when they 361 come to Canada?

The Historical Struggle of Low First-Language Literate (LFLL) Immigrant 362 Women

Theories, Strategies, and Settlement Models that Support Immigrant Women with Low First-Language Literacy (LFLL)

What is the importance of adult literacy? 365

Social Capital and Immigrant/Refugee Women

The Somali Women and Children's Support Network

Learning How to Learn

369

How is Freire's philosophy applied in community-based ESL literacy programs?

Biliteracy Program Strategies

Summary and Conclusions: The Evolution of Strategies for Low First-

Language Literacy (LFLL) Women in Canada

Beneficiaries of Resilience

Chapter References and Attributions

References

Chapter 8: "Too Hot to Handle" - Human Migration on a Rapidly

Warming Planet

Introduction

Alexandru Caldararu

Introductory Remarks

A World in Crisis 390

I. Voluntary vs. Involuntary Migration 390

II. The Global Refugee Crisis

III. The Climate Crisis of the Anthropocene

IV. A Convergence of Crises 
$\begin{array}{ll}\text { Protocols, Policies, and Regulations } & 398\end{array}$

$\begin{array}{ll}\text { I. International Protocols } & 398\end{array}$

Environmental and Climate Refugees $\quad 402$

I. Defining Environmental and Climate Refugees 402

II. The Legalities of Recognizing Environmental and Climate Refugees 403

Recognizing Canada's Ecological and Humanitarian Obligations 406

I. Canada's Immigrant and Refugee System 406

II. Recognizing Canada's Ecological and Humanitarian Obligations 407

III. Canada's Most Recent Responses to Waves of the Global Refugee Crisis 408

Concluding Remarks: The Role of Canada's Settlement Sector 413

Chapter References and Attributions 415

$\begin{array}{ll}\text { References } & 415\end{array}$ 


\section{Copyright}

(C)2021

Canadian Settlement in Action: History and Future by NorQuest College is licensed under a CC BY-NC-SA 4.0 International License, except where otherwise noted. 


\section{Acknowledgement}

This OER project was funded internally by Curriculum Development at NorQuest College.

We extend a very special thank you to the many contributors to this project, including students, writers, reviewers, editors, and administrators who directly or indirectly supported the development of this Settlement Studies open educational resource.

With the support of NorQuest College's Faculty of Skills and Foundational Learning, namely Patti Hergott (Dean) and Lisa Rochman (Associate Dean), the kernel of an idea was put forward for consideration as a Curriculum Development project. Thank you for your ongoing support and commitment to innovative projects and to the settlement sector.

Thank you to Dawn Witherspoon and Robert Lawson in the Curriculum Development department for supporting the project from inception through to publication.

We are deeply indebted to the talented writers who shared their knowledge and expertise, including Alexandru Caldararu, Julie Clements, Rennais Gayle, Christina Hamer, Maria MacMinn Varvos, and Lynn Sutankayo.

Careful review and editing of each chapter was conducted by reviewers who included Oscar Vergara, Suzanne Oswald, Alexandru Caldararu, Lynn Sutankayo, Wendy Ilott, Rosalia Dela Cruz, Rodger Murray, Mitch Fournier, Rebecca Hardie, and Wendy Chambers. Thank you for taking on this important work to ensure a quality OER.

We are also indebted to our dedicated Pressbooks consultant, Sarah Adams, and later in the project, Nicholle Carrière, who uploaded, organized, and copyedited the OER content into Pressbooks. Thank you for the countless hours of work you contributed to the project.

To bring the OER project full circle to its intended audience of learners, Settlement 
Studies students contributed designs and Rahma Farah's design was selected for the book cover. A huge thank you to all students who submitted designs.

This resource was produced by NorQuest College in partnership with the University of Alberta Library's Open Education Alberta publishing project.

\section{回 UNIVERSITY OF ALBERTA LIBRARY}




\section{Foreword}

NorQuest's two-year Settlement Studies diploma is unique among postsecondary programs within Canada. Graduates of the program are aptly able to apply the knowledge, skills, and competencies they have learned through their coursework as well as through extensive work integrated learning opportunities to their work with newcomers to Canada. The program is the first of its kind in Western Canada, and as innovators, NorQuest faculty and staff have undertaken the opportunity to develop an open educational resource (OER) textbook, Canadian Settlement in Action: History and Future. The purpose of the OER is to provide complementary content and resources for learners enrolled in NorQuest's Settlement Studies diploma program as well as to contribute to the settlement field in general.

In the Spring of 2021, a talented group of individuals with expertise and experience in the settlement sector contributed to the development of the textbook. A call for chapter writers was advertised widely and an expert team of writers was assembled. The writers, together with in-house experts at the college, came together at time when conditions for collaboration were challenging due to the global pandemic. The team demonstrated flexibility and commitment to the project despite working remotely across various media and online platforms: Their shared dedication, enthusiasm, and commitment to work in the settlement field is reflected in the chapters of the book. Each writer brings a unique set of skills and intellectual acumen acquired through academia, hands-on experience, and a deep commitment to caring for newcomer populations who choose Canada as their home.

Following the success and recognition of the original textbook, our team was inspired to write an additional three chapters in the Spring of 2022. As a follow up to the initial five chapters, our team of subject matter experts continued to write on important concepts which provide broader insights on settlement in Canada and direct applicability to the settlement worker profession.

The OER textbook is not meant to be a comprehensive exploration of this dynamic and multifaceted field, but rather, as an introduction to issues of importance in the settlement sector. Maria MacMinn Varvos situates the history of settlement services in Canada, including a look at delivery models and perspectives on the value of settlement services. She writes an additional chapter which explores the settlement experiences of low-literacy female learners in Canada. Alexandru Caldararu, the founder of and instructor within NorQuest's Settlement Studies diploma program, 
introduces and situates social justice and anti-oppressive practice in settlement worker practice. An avid proponent of battling climate change, he also writes a chapter on climate migration. Christina Hamer presents types of migration-related trauma and the mental health challenges many newcomers face before arriving in Canada. Rennais Gayle discusses the settlement experiences of older arriving immigrants, particularly focusing on family dynamics. In her chapter, Julie Clements provides an overview of how settlement workers can effectively navigate intercultural communication contexts. Lynn Sutankayo's chapter covers the intriguing topic of gender, sexuality, and culture as it relates to the settlement landscape. While the textbook chapters can be read in the order presented, each chapter presents a unique issue and can also be enjoyed in non-sequential order.

It is with great delight and excitement that we share with you the OER textbook, Canadian Settlement in Action: History and Future. The intention of the project is not only to enhance student learning within our Settlement Studies program, but also to evoke discussions and questions that serve to improve the quality of settlement services across Canada and beyond. It is dedicated to all who take interest in the history and future of settlement.

Wendy Chambers, Ph.D., Academic Program Manager

Faculty of Foundational Skills and Learning, NorQuest College

Oscar Vergara, Ed.D. (candidate), Program Chair

Settlement Studies, NorQuest College

September 30, 2021

Updated November 10, 2022

Foreword | xvii 



\section{CHAPTER I: THE HISTORY OF SETTLEMENT SERVICES IN CANADA}





\title{
Introduction
}

\author{
MARIA MACMINN VARVOS
}

The Canadian settlement sector's systems and best practices have evolved parallel to Canada's immigration history. Settlement and integration services have moved from the informal guidance of family and community to organized systems instituted by professional organizations. Just as systems have grown and evolved over the past 150 years, so have social attitudes, social values, and morality. Government immigration policies reflect the social, religious, and economic state of the country. The social conscience and the economic needs of Canada have guided and influenced how settlement services have been supported and implemented (Griffith, 2015, 2017).

This chapter will give you historical knowledge as well as opportunities to reflect on, relate to, and understand the interconnectedness of history, social responsibility, and economy. You will learn the foundational factors that have contributed to the skills and best practices that are being developed throughout the Settlement program. Articles, videos, case studies, and interactive reflective practice activities will serve as the impetus for learning in this chapter.

Specific Learning Outcomes

By the end of this introduction section, you will be able to

1. Apply prior knowledge and experience to the history of settlement discussions and activities

2. Demonstrate understanding of keywords used in this chapter

Learning Activity 1: Reflective Practice - Keep a Chapter Journal 
In the first section of this chapter, you will explore and share your prior knowledge of immigration and settlement in Canada.

Start a chapter journal to track your observations and learnings. Answer the following questions in your chapter journal:

1. Have you or someone you know had an experience that required settlement services?

2. Describe the challenge and the solution. Who was involved? What resources were used?

Discussion Forum: Share one of your answers on the Discussion Forum. Read the posts of your peers, write comments, and ask questions to start a dialogue.

\section{Key Terms}

Every sector has a body of knowledge that is accompanied by sector-specific language and acronyms. Sector-specific language can be thought of as a subsector of a familiar language. Learning these keywords and acronyms will facilitate the communication of shared knowledge in this course as well in the sector when employed. A short "Settlement Sector" language lesson follows.

The following terms will be encountered in this chapter: 


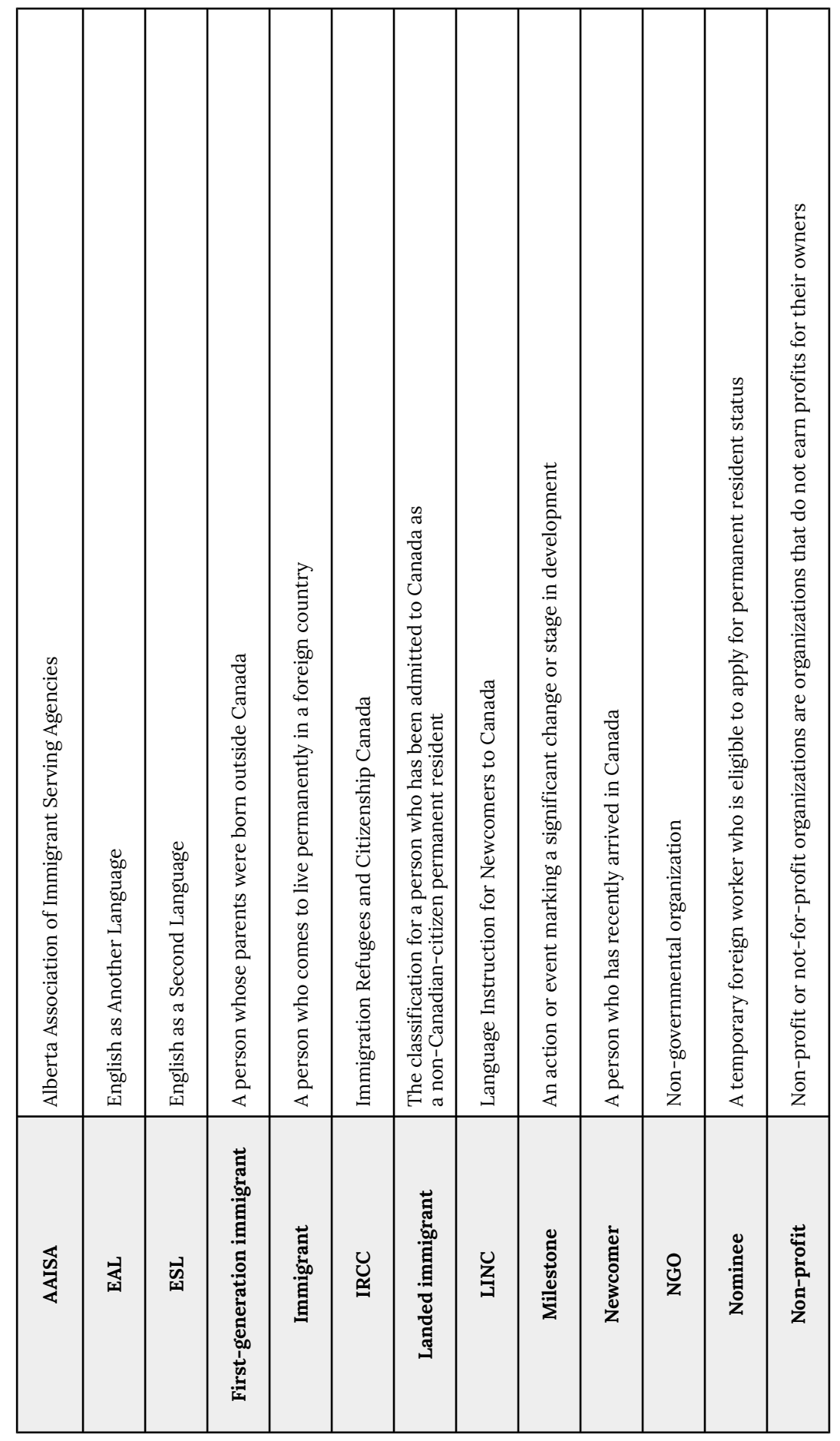




\begin{tabular}{|c|c|c|c|c|c|c|}
\hline 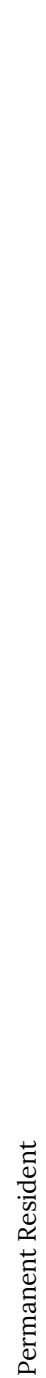 & 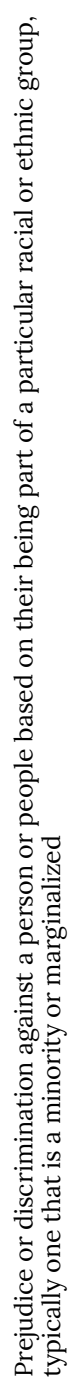 & 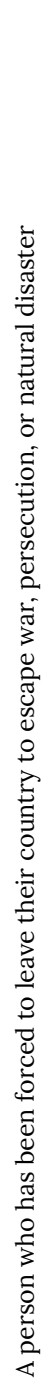 & 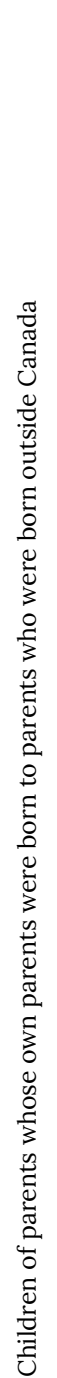 & 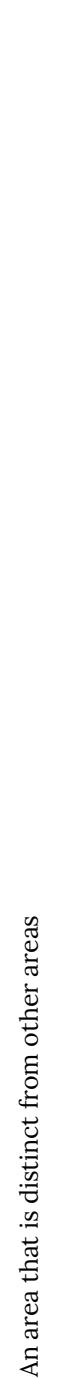 & 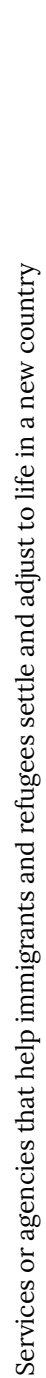 & 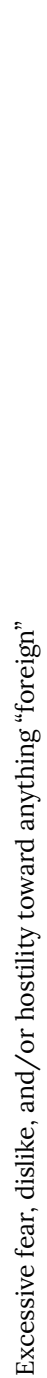 \\
\hline $\mathscr{a}$ & 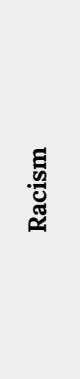 & 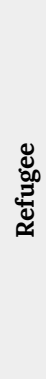 & 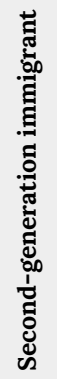 & 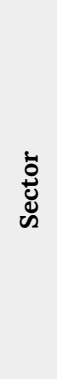 & 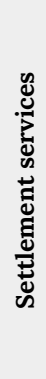 & 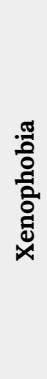 \\
\hline
\end{tabular}




\section{Settlement Services}

Specific Learning Outcomes

By the end of this section, you will be able to

1. Summarize the historical context of settlement services in Canada

2. Define milestones in the history of immigration in Canada

\section{Introduction to Settlement and Immigration in Canada}

From 2019 to 2021 the Canadian government welcomed 300,000 immigrants. This number will increase to 401,000 to 421,000 from 2021 to 2023 . More than $50 \%$ of this target has been allocated to "Federal economic, provincial/territorial nominees" as indicated in the 2021-2023 Immigration Plan chart that follows. Consequently, the value of immigration is not purely an esoteric endeavour to satisfy Canada's ideological pursuit of building a multicultural nation. The value of immigration is a practical investment in the economic future of Canada (Campbell Cohen Law Firm, 2021; ElAssal \& Thevenot, 2020).

2021-2023 Immigration Levels Plan

\begin{tabular}{|c|c|c|c|c|c|c|c|c|c|}
\hline \multirow[b]{2}{*}{ Immigrant Category } & \multicolumn{5}{|c|}{2021} & \multirow{2}{*}{$\begin{array}{l}20229 \\
\text { High } \\
\text { Range }\end{array}$} & \multirow{2}{*}{ Target } & \multicolumn{2}{|r|}{20239} \\
\hline & Target & $\begin{array}{l}\text { Low } \\
\text { Range }\end{array}$ & $\begin{array}{l}\text { High } \\
\text { Range }\end{array}$ & Target & $\begin{array}{l}\text { Low } \\
\text { Range }\end{array}$ & & & $\begin{array}{l}\text { Low } \\
\text { Range }\end{array}$ & $\begin{array}{l}\text { High } \\
\text { Range }\end{array}$ \\
\hline $\begin{array}{l}\text { Overall } \\
\text { Planned } \\
\text { Permanent } \\
\text { Resident } \\
\text { Admissions }\end{array}$ & 401,000 & 300,000 & 410,000 & 411,000 & 320,000 & 420,000 & 421,000 & 330,000 & 430,000 \\
\hline
\end{tabular}

Supplementary Information for the 2021-2023 Immigration Levels Plan, Overall Planned Permanent Resident Admissions chart row (Immigration, Refugees and Citizenship Canada [IRCC], 2021) 


\section{Restoring a Declining Population: The Impetus for Immigration in Canada}

Immigration has been vital to the development of Canada to sustain steady economic growth. Canada's population is aging, and it is not being replaced at the same rate that it is declining. The following video looks at the changes throughout Canada's history and how the aging population has affected immigration strategies. The video also points out how the need for increased immigration has affected the cultural identity of Canada.

One or more interactive elements has been excluded from this
version of the text. You can view them online here:

https://openeducationalberta.ca/settlement/?p=194\#oembed-1

TEDx. (2013, October 23). The big shift - understanding the new Canadian: Darell Bricker at TedxToronto [Video]. YouTube. https://www.youtube.com/watch?v=nquKRW7W78I 


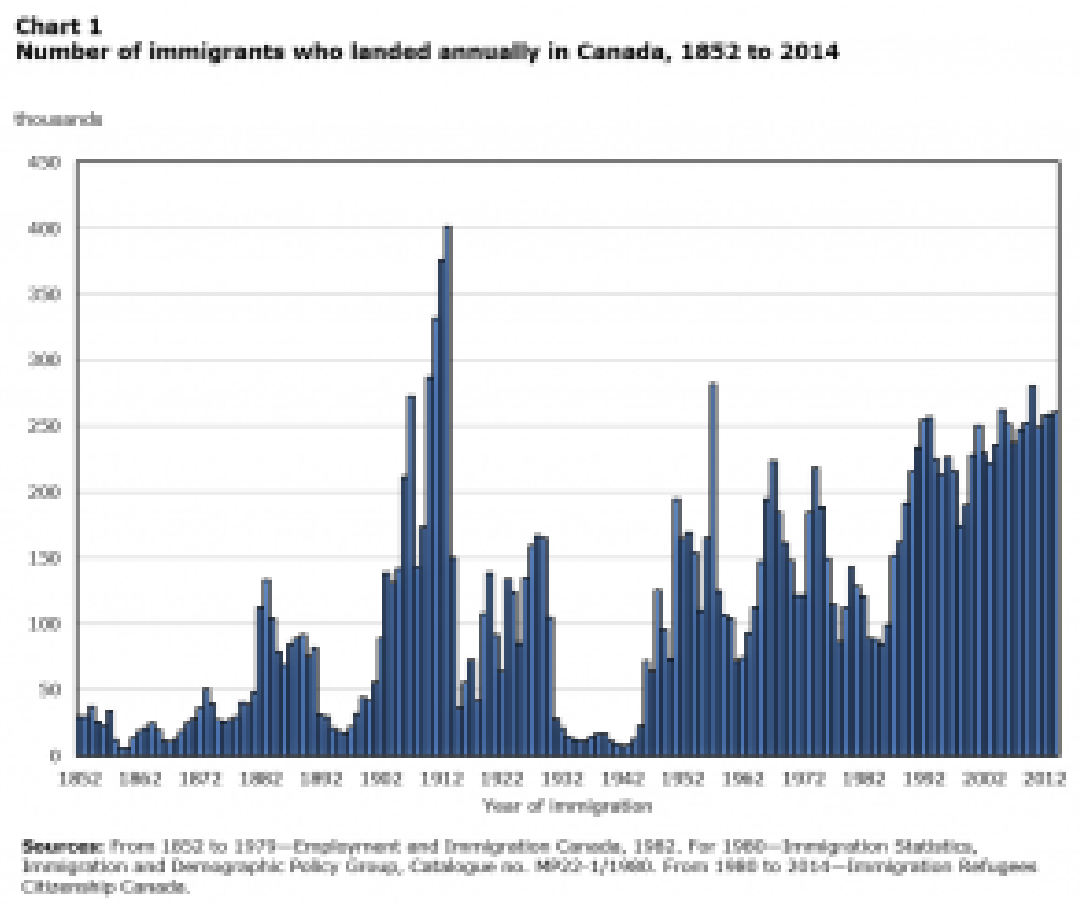

Chart 1. Number of immigrants who landed annually in Canada, 1852 to 2014 (Statistics Canada, 2016)

Chart 1 (Statistics Canada, 2016) gives an overview of immigration over 150 years of Canadian history. By 2021, the number of immigrants had reached 300,000 (Standing Committee on Citizenship and Immigration, 2019) and is targeted to reach 421,000 by 2023. Immigration from the 1850 s to the 1880 s was approximately 20,000 to 50,000 . Compared to the immigration numbers of 2020 to 2021, there has been an increase of approximately $88 \%$ over a span of 143 years. To put this increase in immigration into perspective, consider that the population of Canada in the mid-1880s was 2.5 million compared to the population of Canada in 2021 of approximately 28 million (O'Neill, 2020).

Immigration rises and falls in step with the major turning points in history. Immigration peaked in the early 1900s during the Industrial Revolution. The early 1900s was a time of new inventions and the start of the mass production of goods in Canada. It was a time that spurred a level of growth that required more people to build the country's infrastructure and industry. Canada's population growth increased 
exponentially from 2.5 million in the mid-1800s to 5.5 million in 1900 , an increase of $45 \%$ in 50 years (O'Neill, 2020).

\section{Acknowledgement of Indigenous Peoples Prior to Settlement in Canada}

It is of great importance to note that prior to settlement in Canada, the land was occupied by Indigenous Peoples in thriving communities from time immemorial. Wilson (2018) expands on the history of colonization in Canada:
Before the arrival of European explorers and traders, North America was occupied by Indigenous Peoples living and thriving with their own distinct cultures, languages, and ways of knowing. ...In its early days, the relationship between European traders and Indigenous Peoples was mutually beneficial. However, as time went by and more European settlers arrived, the relationship between the two peoples became much more challenging. ... When settlers arrived in North America, they regarded it as terra nullius, or "nobody's land." They simply ignored the fact that Indigenous Peoples had been living on these lands for thousands of years, with their own cultures and civilizations. (Colonization section, para. 1, 4, 5)

Read more about the history of colonialism that still affects Indigenous Peoples today in Chapter 2, Section G. Colonialism, Genocide, and Anti-Indigenous Racism.

This acknowledgement contains material taken from Pulling Together: Foundations Guide, Section 2: Colonization by Kory Wilson, and is used under a CC BY-SA 4.0 license. 


\section{Canada: New Exploration Leads to New Directions}

Prior to documented immigration, the Italian explorer John Cabot or Giovanni Caboto landed on the traditional territories of Indigenous Peoples of Turtle Island, known today as Canada, in 1497-1498. Giovanni Caboto was a navigator and explorer from Genoa, Italy. His destination was Asia, but Caboto decided to take a new route, heading west instead of east. He thought he was taking a shortcut to Asia, but his ship landed in a very different location (Biography Editors, 2020). His voyage led to the colonization of what was initially referred to as the "New World," and later became known as Canada.

Caboto's journey laid the foundation for the subsequent settlement in Canada of people from English- and French-speaking countries such as England, Ireland, Scotland, and France, and the predominant languages of Canada spoken by the original settler communities thus became English and French. Most of these immigrants left with limited resources other than life skills and experiences acquired in their countries of origin. 


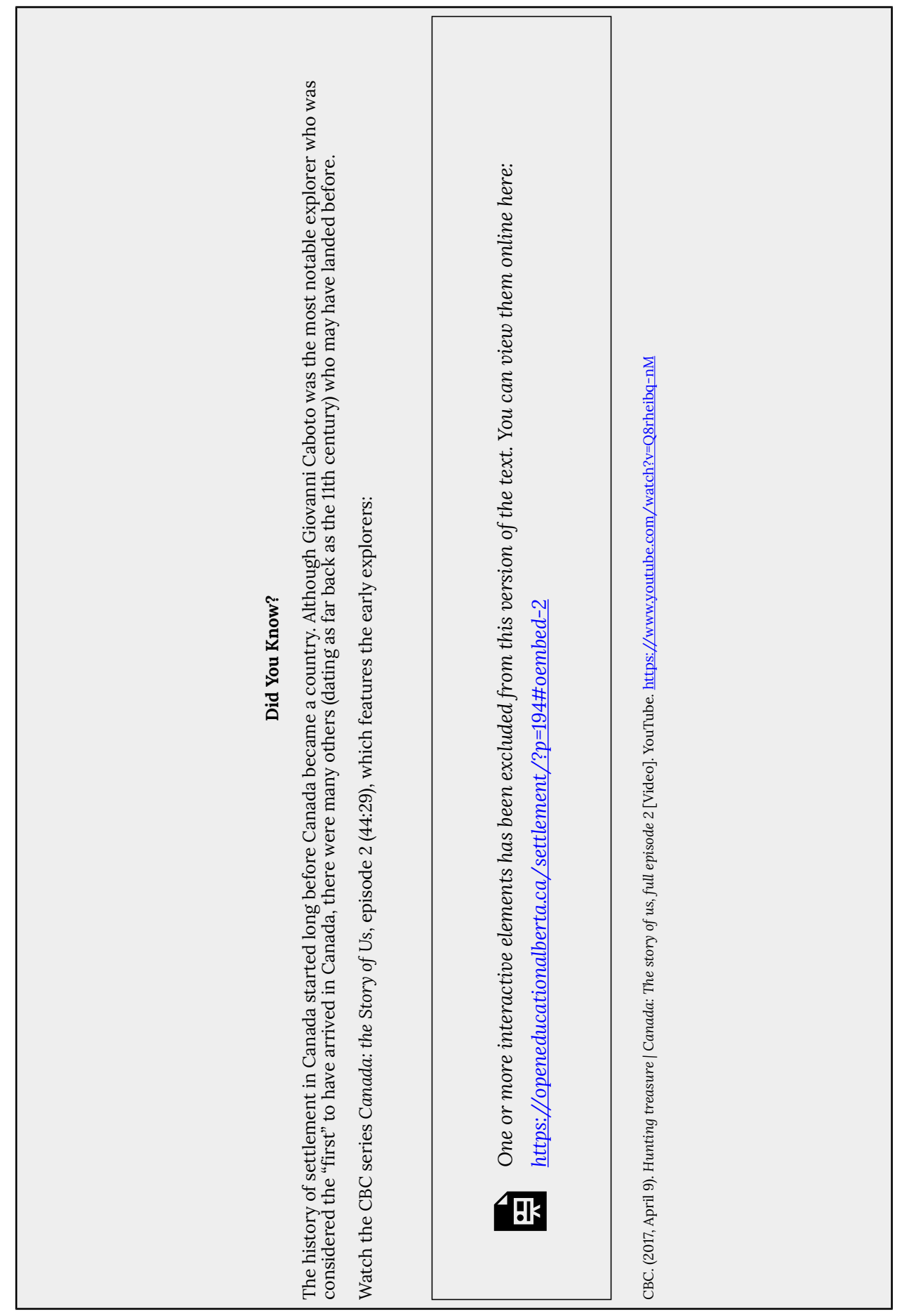


The settlement of Canada, started during the British-French conflicts from 1600 (Canadian Museum of History, n.d.) to the 1750s. This was long before the surge in immigration in the early 1900s. The need for adventure influenced explorers and traders to venture out to North America in the 1700s and 1800s. Eventually, many British and French citizens decided to set out to Canada to establish better lives for themselves. The wave of immigration to Canada in the 1900s was influenced by the collapse of social structures in European countries.

Throughout Canada's history, including the 1900s, the push to increase immigration was driven by the demands of the Canadian economy. Canada was an attractive destination because of the growing economy and the quality-of-life opportunities that were absent in Europe. Immigrants were attracted to the Yukon Gold Rush, the development of the continental railway across Canada, the offer of land for farming, and the establishment of government policies that promoted immigration. The opportunity to live in a free, fair, and just society that offered economic opportunities to people of diverse backgrounds has transcended generations of immigrants who make their way to Canada.

In the TEDx Talk Why Canadian history isn't as boring as you think it is (16:11), presenter Chris Turner gives an overview of early Canadian history. The Yukon Gold Rush is highlighted as an interesting piece of history that changes the perception that Canada's history is neither memorable nor interesting.
圆 One or more interactive elements has been excluded from this version of the text. You can view them online here: https://openeducationalberta.ca/settlement/?p=194\#oembed-3

TEDx Talks. (2013, July 16). Why Canadian history isn't as boring as you think it is: Chris Turner at TEDxYYC [Video]. YouTube. https://www.youtube.com/watch?v=CBPvQRazhw8 


\section{Canada's Immigration History: Milestones and Stories}

Specific Learning Outcomes

By the end of this section, you will be able to

1. Examine the historical evolution of government immigration policies and their influence on current settlement practices

2. Analyze the historical settlement challenges experienced by groups of immigrants in Canada since the early 1900s

This section of the chapter explores Canadian history from a different lens. It will be explored from the perspective of immigration and settlement. The significant milestones in the history of immigration from the 1880s to 2019 will be reviewed in this section. The first historical milestone covers the period from 1885 to 1923. 


\section{Milestone r: Immigrants Build the Foundation and Infrastructure of Canada}

Those who settled in Canada as far back as the mid-1600s came from Anglo European (British, Scottish, Irish) and French backgrounds. They were drawn to Canada because of the fur trade and worked for the Hudson's Bay Company. This group played a role in the development of the first social and economic structures of the newly-formed settler Canadian society.

From the mid-1800s to the early 1900s, labourers were recruited to build the railways and work in factories, and immigrants who had agricultural experience settled in the western and the central Prairies to develop farmland. Immigrants who were recruited for these purposes came from Europe.

From 1867 to 1914 was a period of high immigration. Around 1897, about 2,000 Doukhobors from Russia landed in Halifax, en route to farms in the West. Refugees from Russia, as well as Jews, Mennonites and Doukhobors, settled in Canada, primarily in regions such as the Prairies. 


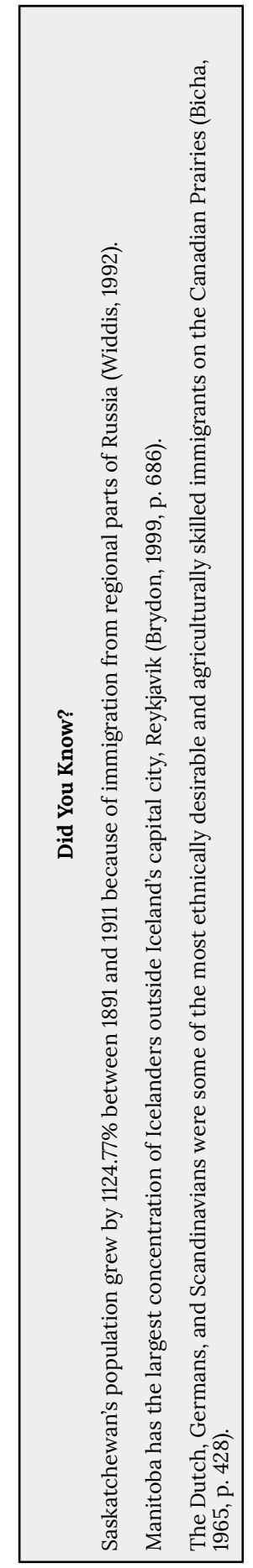




\section{Stories of Acceptance and Rejection}

The social values and ideology of the mid-1800s to early 1900s influenced the creation of policies that blocked nonEuropean immigration but opened the door to people with European backgrounds. A systematic effort to limit non-European immigration resulted in the implementation of the Chinese head tax from 1885 to 1903 . Originally $\$ 50$, the head tax eventually rose to $\$ 500$, which limited the number of Chinese people who could afford to immigrate. Unfortunately, the head tax legislation continued well into the 1920s, when Chinese immigration was virtually suspended. As noted in the chart above, that legislation by the Canadian government is known by Chinese Canadians as "Humiliation Day", July 1, 1923 (Lee, 2017), the date the Chinese

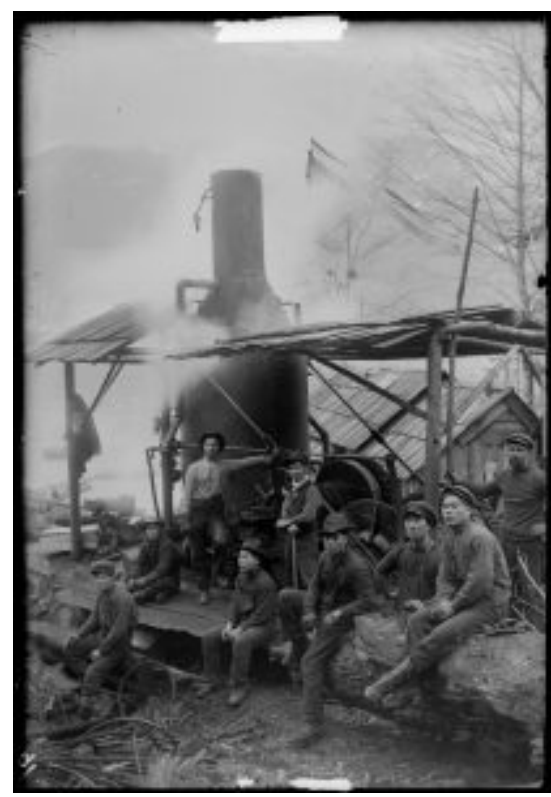

Asian loggers and steam donkey. British Columbia, c. 1900.

Exclusion Act was passed. This Act served to exclude further immigration from China to Canada.

Dr. Henry Yu retells his grandfather's story about how the Chinese head tax and the Chinese Exclusion Act affected his grandfather personally, as well as how it impacted the Chinese community in Vancouver where he had settled. Click here to read his story.

The Chinese head tax is an example of systemic racism. However, it was not considered racist to block immigration based on race at this time in Canadian history.

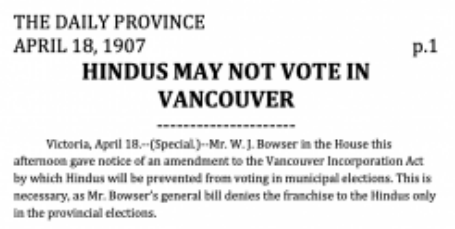

Hindus May Not Vote in Vancouver (newspaper article transcript), April 18, 1907, The Daily Province.
There were some notable exceptions of immigrants from non-European countries who broke through systemic barriers, put down roots in Canada, and left enduring legacies. On January 1, 1897, more than 5,000 South Asians, over 90\% of them Sikhs, came to British Columbia. This group was part of a military troop from Hong Kong and Malaysia who were 
on their way back from London, England, via Atlantic Canada after celebrations for Queen Victoria's Jubilee. About 45 men eventually came back to settle in the Lower Mainland of British Columbia and across the border in Bellingham, Washington. The number of South Asian men grew from 45 to 5,179 between 1904 and 1908 (University of the Fraser Valley, 2021). They settled in Canada before the immigration of Sikhs was banned in 1908. The newspaper article "Hindus May Not Vote in Vancouver" from 1907 (shown above) demonstrates the prevalence of systemic racism in the Canadian government policies of that time. Despite this effort to ban South Asians from Canada, there is a large community of Sikhs who have established roots in the Vancouver and southern regions of British Columbia.

The video below by Satpal Sidhu is an account of the challenges faced by the South Asian Sikhs and the events that led to the Bellingham riots in 1907. Although many Sikhs ended up in Bellingham, Washington, there was a group of migrants that crossed the American boarder into Canada. This part of Canadian and American history established not only the roots of South Asian Sikhs in Canada, but also the social ideology that influenced the immigration practices of that time.

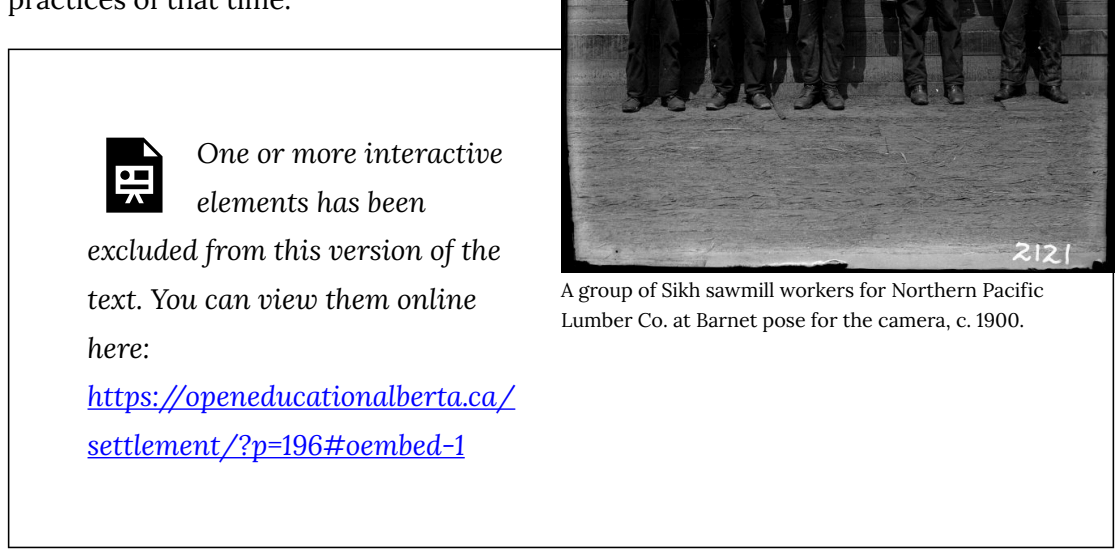

Sidhu, S. (2014, September 16). We are not strangers documentary about 1907 Bellingham Riots [Video]. YouTube. https://www.youtube.com/watch?v=mvn_LpXj694\&t=306s

This ingrained racism still lingers in today's society, though not as overtly as it was in the early 1900s. Canadians who may not be aware of this community's history may 
still consider South Asians as a recent immigrant group instead of understanding their long history and influence on the development of Canada.

Another part of Canadian Sikh history is retold in a story about the first Sikh immigrant family in Canada. The story is retold in this video called An Act of Grace: UBC's first Sikh Immigrant Family.

This story further establishes the influence of the Sikh community since the early 1900 s.
圈
One or more interactive elements has been excluded from this
version of the text. You can view them online here:
https://openeducationalberta.ca/settlement/?p=196\#oembed-2

University of British Columbia. (2016, June 15). An act of grace: UBC's first Sikh immigrant family [Video]. YouTube. https://www.youtube.com/watch?v=IUcn8olejWs

A third group of Asians, the Japanese, have an impactful story that is recounted in a novel called Mikkôsen Suian Maru (The Stowaway Ship Suian Maru), written by Nitta Jiro (1979/1998). Although the novel is fictional, it is based on historical facts about a little-known piece of Canadian Japanese history. On January 01, 1906, a group of 82 Japanese men who were stowaways on the ship Suian Maru landed at Beecher Bay on Vancouver Island. David Kenneth Allan Shulz recounts this piece of history in his thesis Japanese "Entrepreneur" on the Fraser River: Oikawa Jinsaburo and the Illegal Immigrants of the Suian Maru (Sulz, 2003).

There is little documentation about this part of Canadian Japanese immigrant history. James D. Cameron (2005) writes in his article, "Canada's Struggle with Illegal Entry on Its West Coast: The Case of Fred Yoshy and Japanese migrants before the Second World War," that the Japanese stowaways were apprehended by the British Columbia RCMP but were eventually allowed to stay because they were considered a source of cheap labour. However, they were not given the same rights and freedoms afforded to Canadians and European immigrants.

The struggles of these two groups of immigrants are important to understand because they reflect the similarity of challenges among non-European immigrants in recent Canadian history. Racism continued to affect immigrants from non-European countries even after the Canadian government eliminated racist immigration policies in 1962. Racism also affects how segments of Canadian society have perceived people from the Middle East, South America, Asia, South East Asia, Africa, and the West Indies 
who have immigrated to Canada at various stages in Canadian history. Stereotypes and fear of the unfamiliar have influenced how immigrants are treated in Canadian society and subsequently how their needs have been addressed by settlement service providers over the past 140 years. Historically, settlement practitioners have been primarily from white, Christian backgrounds. However, the profile has changed over the last 30 to 40 years. More and more settlement practitioners now have cultural and ethnic backgrounds that better represent the cultures and ethnic backgrounds of the immigrants that they serve.

\section{Milestone 2: Post-War Immigration Challenges}

The next milestone covers an era of political strife in Europe that required Canada's military support. After the Second World War, immigration increased significantly because of an influx of war brides. The large numbers of war brides that accompanied returning soldiers came through the famous Pier 21 port in Halifax. 


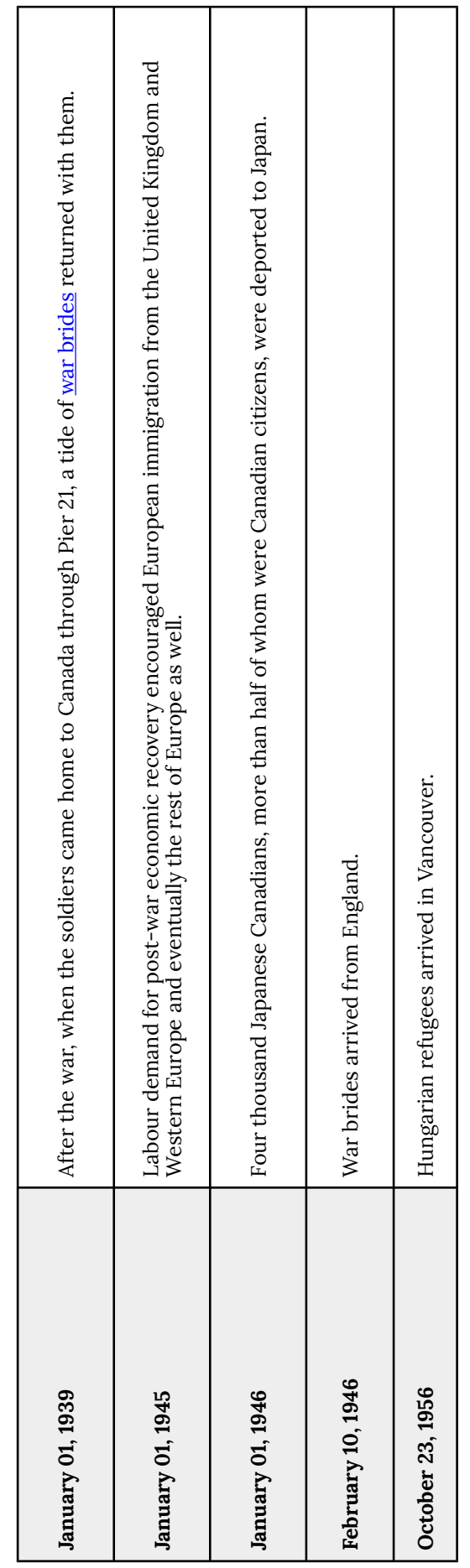


After the Second World War, the Canadian economy started to recover rapidly, and as a result, there was a great demand for labour. During this time, the government encouraged immigration from Europe, this time promoting immigration from the United Kingdom and Western Europe. At this time, the political climate in Eastern Europe created mistrust of communism by the West that became known as the Cold War, which essentially stopped open immigration from this region of Europe (Troper, 2021).

In post-World War II Canada, Japanese Canadians became the target of racism because of Canada's support for America following the 1941 Japanese attack on Pearl Harbor. The video below, Japanese deportations in Canada during WWII : Throwaway Citizens (1995) - The Fifth Estate, gives a personal insight into this difficult part of Japanese Canadian history. The documentary uses the term "ethnic cleansing" to describe this period of Canadian history.

One or more interactive elements has been excluded from this version of the text. You can view them online here:

https://openeducationalberta.ca/settlement/?p=196\#oembed-3

Fifth Estate. (2017, August 25). Japanese deportations in Canada during WWII: Throwaway citizens (1995) The Fifth Estate [Video]. YouTube. https://www.youtube.com/watch?v=ggNYkFg6AjA

\section{Internment Camps During World War I and World War II}

World War II geopolitics brought the fight against communism, fascism, and Nazism into the Canadian social consciousness and affected two established Canadian ethnic groups-German and Italian Canadians. These two ethnic groups came from countries that were political enemies of Britain and its allies. This led to a deportation order under the War Measures Act. This Act took away the civil liberties of German and Italian Canadians and subjected them to deportation or imprisonment in one of 26 internment camps. Internment camps in Canada during World War II held 24,000 people, including 12,000 Japanese Canadians (Roy, 2020). Other Canadian ethnic groups who were interned were from other countries at war with Canada's allies. Immigrants from the Austro-Hungarian and Ottoman empires, as well as from Germany and Bulgaria (Roy, 2020) were required to register themselves with the 
Canadian government as "enemy aliens." They were subsequently rounded up and sent to internment camps across Canada. The following video documents the stories of some individuals who were affected by these War Measures Act practices. This video is called The Surprising Story of Canada's Enemy Aliens.

One or more interactive elements has been excluded from this

믓 version of the text. You can view them online here:

https://openeducationalberta.ca/settlement/?p=196\#oembed-4

Storyhive. (2017, May 19). The surprising story of Canada's enemy aliens [Video]. YouTube. https://www.youtube.com/watch?v=UY4vTBQTpUA\&t=20s

The following is a poem written in 1940 and translated from Italian that recounts the experience of Emilio Garlardo, who was in one of the 26 interment camps found throughout Canada. Emilio is writing from the camp in Petawa, Ontario (Columbus Centre, n.d., para. 1). 


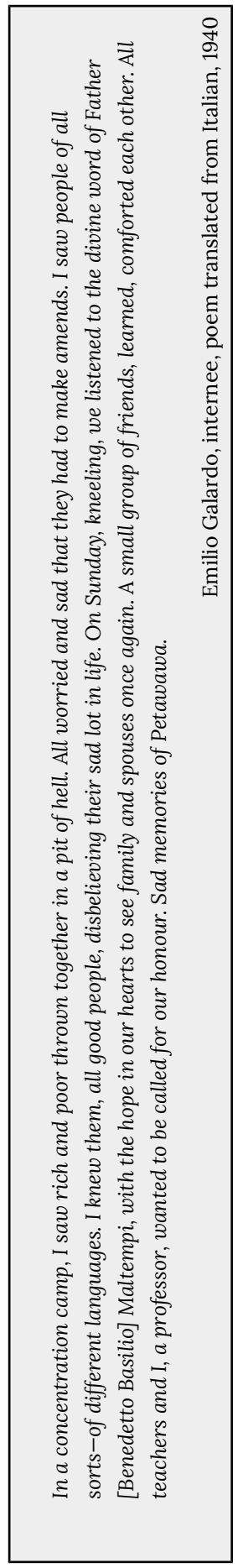




\section{Milestone 3: Canada's Evolving Immigration Policy}




\begin{tabular}{|c|c|c|c|c|c|c|c|c|c|c|c|c|c|c|c|c|}
\hline 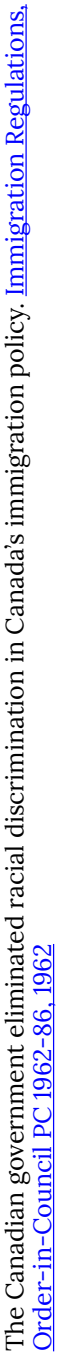 & 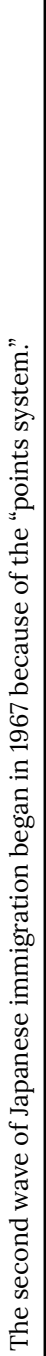 & 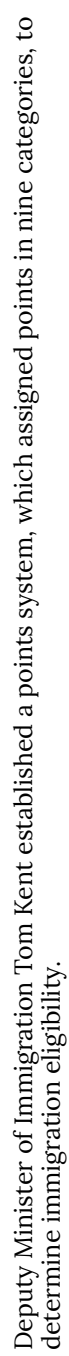 & 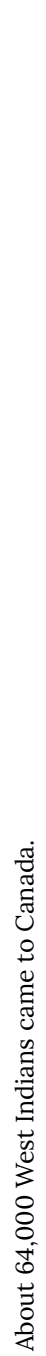 & 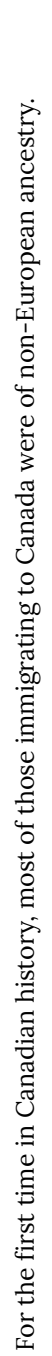 & 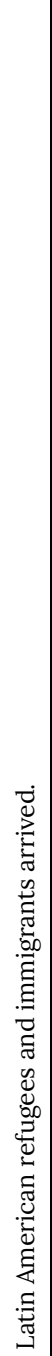 & 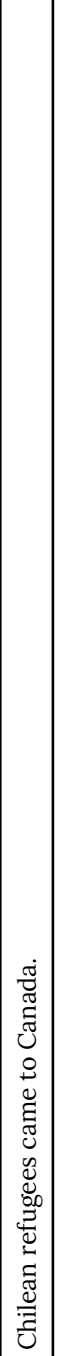 & 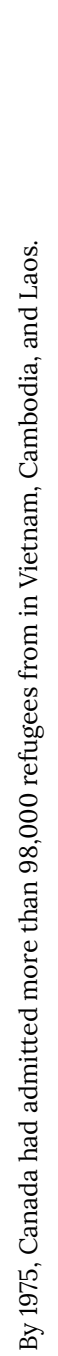 & 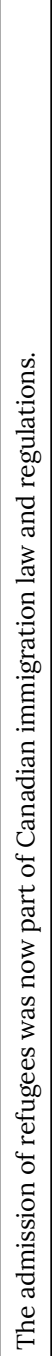 & 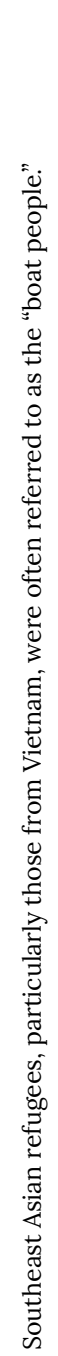 & 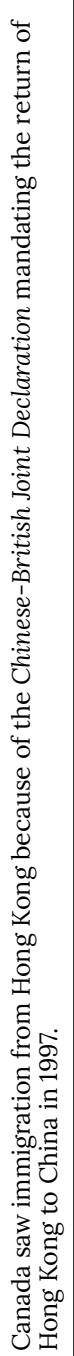 & 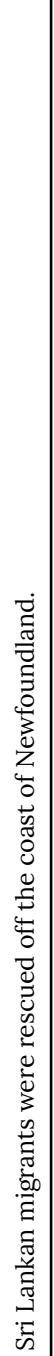 & 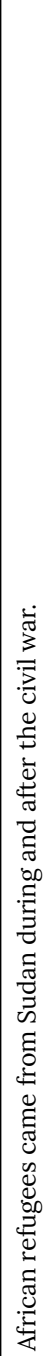 & 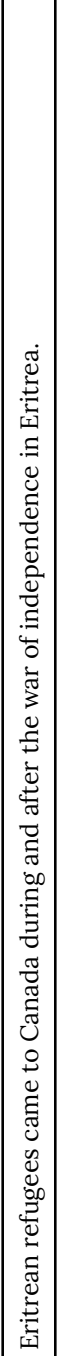 & 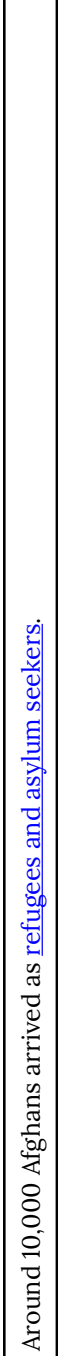 & 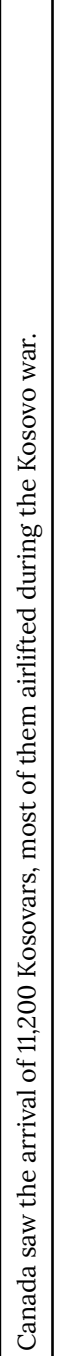 & 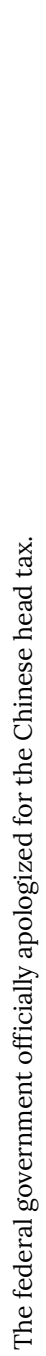 \\
\hline 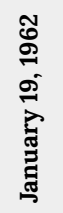 & 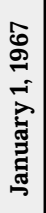 & 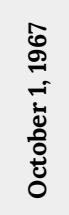 & 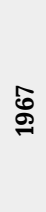 & 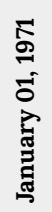 & 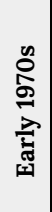 & ڤొ & 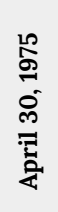 & 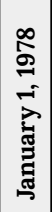 & 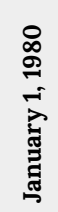 & 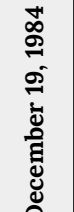 & 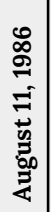 & 怘 & 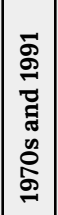 & \begin{tabular}{|l} 
L \\
$\stackrel{2}{2}$ \\
$\stackrel{2}{\circ}$ \\
$\stackrel{2}{\circ}$ \\
$\stackrel{2}{2}$
\end{tabular} & 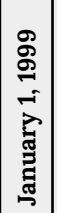 & 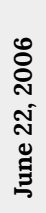 \\
\hline
\end{tabular}




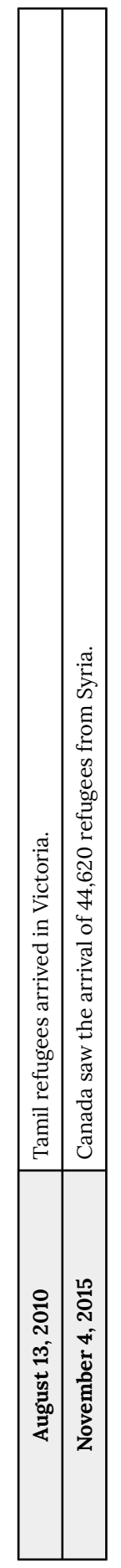


The next milestone in Canada's immigration history is a welcome pivot of ideology influenced by a new era of social consciousness of the 1960s. Shannon Conway (2018) describes this in her journal article abstract, "From Britishness to Multiculturalism: Official Canadian Identity in the 1960s":

"The 1960s was a tumultuous period that resulted in the reshaping of official Canadian identity from a predominately British-based identity to one that reflected Canada's diversity. The change in constructions of official Canadian identity was due to pressures from an ongoing dialogue in Canadian society that reflected the larger geopolitical shifts taking place during the period. This dialogue helped shape the political discussion from one focused on maintaining an outdated national identity to one that was more representative of how many Canadians understood Canada to be. This change in political opinion accordingly transformed the official identity of the nation-state of Canada" (p. 9).

This "geopolitical shift" (Conway, 2018) influenced the Canadian government to implement a policy that eliminated racial discrimination in Canada's immigration policy. This shift in political and social ideology led to the establishment of a point system. On October 1, 1967, Deputy Minister of Immigration Tom Kent established a system that determined eligibility by assigning points in nine categories. This system established a more fair and transparent set of criteria for immigration approval. The point system criteria gave points in categories related to education, profession, financial resources, family status, and English- or French-language proficiency. It eliminated bias based on race and religion. 


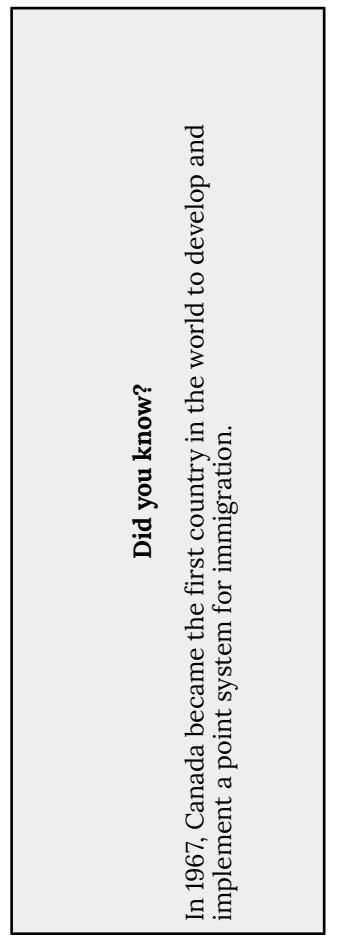


For the first time in Canadian history, most immigrants accepted for entry into Canada were of non-European descent. The scope of immigration extended beyond the European landscape to include people who fit the point system criteria. Groups of non-European immigrants came from Asia, South Asia, Latin America, Africa, and the Caribbean (Whitaker, 1991).

The concept of multiculturalism grew out of the new social consciousness of that time. However, the high criteria standards excluded the unskilled labourers who had once been a priority when the country was building infrastructure and industry. The system was designed to assign higher points to applicants who had the education, training, and skills required by industries in demand. The White Paper on Immigration created in 1966 challenged

this systemic practice of restriction on immigration and offered recommendations for immigration regulations enacted in 1967.

\section{Refugees and Asylum Policy}

At the end of World War II, Canada accepted refugees who were displaced by the war. Displaced persons such as surviving Jewish people from Germany and Poland were encouraged to find refuge in Canada after the defeat of Germany and Italy. Refugees from war-torn countries such as Hungary (1956) and Czechoslovakia (1968) were invited on an ad hoc basis according to their individual circumstances. Eventually, a government refugee policy was established in 1976 to set guidelines for inviting refugees to Canada. These guidelines for accepting refugees were developed in response to humanitarian crises created by war or environmental disasters. The various waves of refugees are identified according to the timeline in the following chart: 


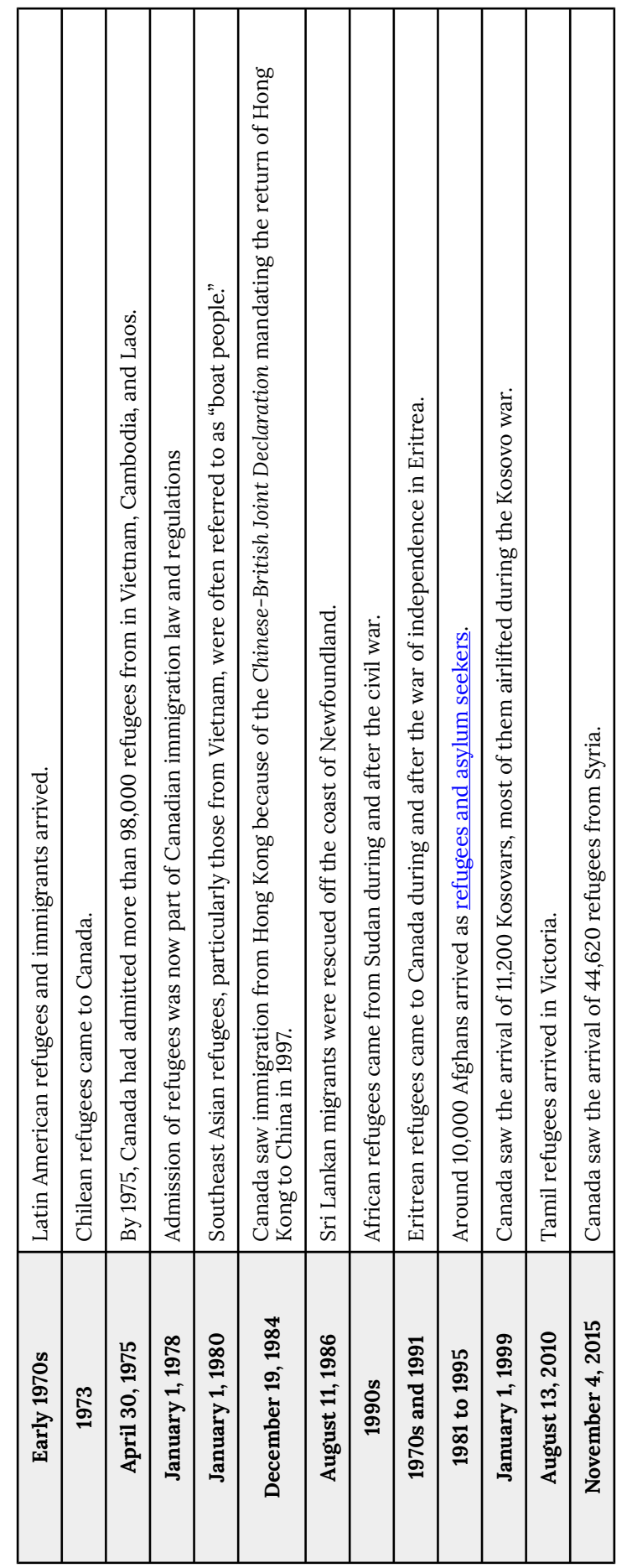




\section{Image Credits (images are listed in order of appearance)}

Timms, P. (190-). Asian loggers and steam donkey [Photograph]. Vancouver Public Library Historical Photograph Collections. VPL Accession Number: 78316. https://www.vpl.ca/historicalphotos

Hindus may not vote in Vancouver. (1907, April 18). Vancouver Daily Province. Vancouver, BC.

Timms, P. (190-). A group of Sikh sawmill workers for Northern Pacific Lumber Co. at Barnet pose for the camera [Photograph]. Vancouver Public Library Historical Photograph Collections. VPL Accession Number: 7641. https://www.vpl.ca/ historicalphotos 


\section{Settlement and Integration}

Specific Learning Outcomes

By the end of this section, you will be able to

1. Identify the factors that have influenced settlement practices in Canada

2. Interpret influences on settlement practices throughout the history of immigration related to the three (3) milestones identified in the previous sections

3. Debate the value of these varying influences through discussions and in writing activities

\section{History of Settlement Services in Canada Glossary Terms Flashcards}

Let's review the glossary terms that were introduced in this chapter's introduction. Use the flashcards to practise learning these words and acronyms.

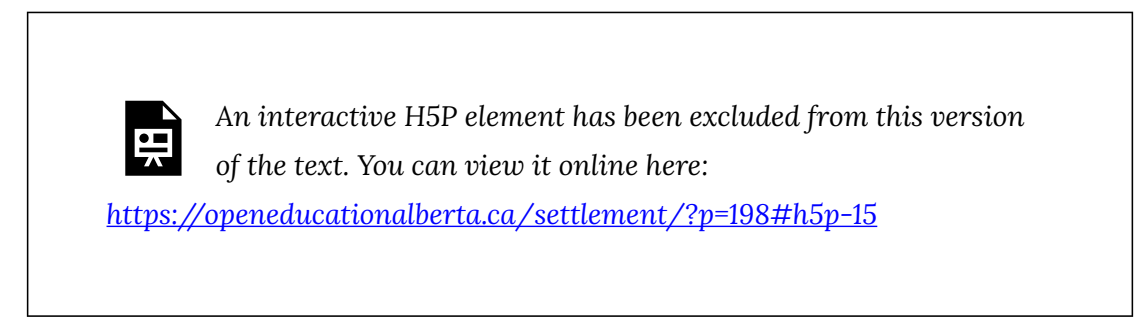




\section{Essential Steps Upon Arrival to Canada}

There are fourteen (14) essential steps that immigrants face during the first few weeks of arrival. These steps are not easy to navigate without the support of family, friends, or community settlement services.

Upon entry into Canada (Mishra, 2020), immigrants must present their passport and ID. They must also complete the following 14 steps:

1. Prepare for questions about their purpose for entry

2. Check their visa or residency status - Provincial nominee

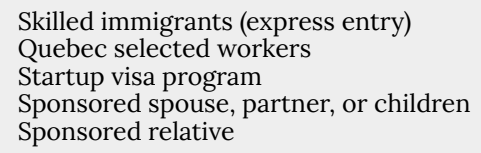

3. Get a social insurance number from Service Canada

- Get this at the Service Canada counter at the airport

4. Look for permanent accommodation or move into prearranged accommodation

5. Open a bank account

6. Apply for a library card

7. Apply for a driver's licence

8. Get a public transit card

9. Get a local mobile phone number

10. Register for a provincial healthcare card

11. Sign up for a family doctor

12. Register their children for school

13. Become familiar with the city and the community where they are living

14. Look for employment

Pre-arrival services are offered online by Immigration, Refugees and Citizenship Canada (IRCC) to immigrants and refugees. The purpose of pre-arrival services is to help immigrants with some of the initial settlement steps before they arrive in Canada. These services are available online through the Government of Canada portal here.

This free online service helps immigrants and refugees to do the following:

- Prepare for their move to Canada

- Have their education, work experience, and other credentials recognized in Canada

- Connect with employers to find a job

- Connect with free services after arriving in Canada (IRCC, 2021) 


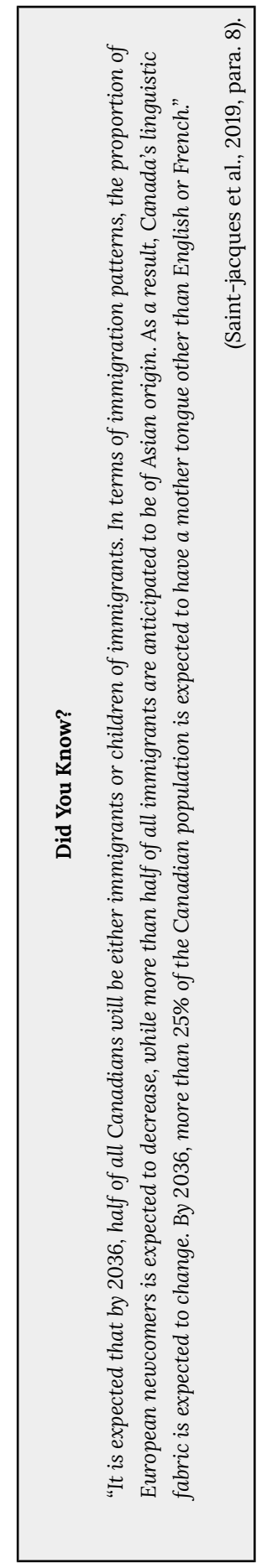




\section{Where Can Newcomers Get Help with These Steps After Arrival?}

In the early days of immigration, policies did not legislate a system of organized settlement services. Settlement support was provided by friends, family, and community members who spoke a common language and had compatible cultural or religious practices.

In today's Canadian society, there are a wide variety of immigrant service agencies to help immigrants with short term and long-term settlement integration challenges. While there is no shortage of these organizations in urban areas, services in smaller communities are less accessible. Services are concentrated in large cities where most immigrants settle. Large cities offer more options for employment, housing as well as government services that are offered in a number of languages.

Unfortunately, not all languages are represented in settlement organizations. For refugees from countries such as South Sudan and western Ethiopia, there are fewer first-language service options in languages such as Nuer and Dinka. Consequently, individuals from these language groups usually reach out to family, friends, and members from their ethnic communities. For an immigrant or refugee to go to an organization where they may not be able to communicate because they have limited or no English-language skills and where services are offered by settlement practitioners who may not understand their culture can be an intimidating experience. From the time that Canada opened immigration in the 1970s, immigrant settlement services have made strides in increasing the range of languages in which services are offered. The following are examples of settlement and integration organizations that offer settlement services in multiple first languages:

\begin{tabular}{ll}
\hline Immigrant Services Calgary & Over 70 languages \\
Calgary Immigrant Women's Association & 135 languages \\
Calgary Catholic Immigration & Over 60 languages \\
Edmonton Immigrant Services Association & 28 languages \\
\hline
\end{tabular}

\section{The Role of Immigrant Settlement Services}

Settlement and integration services can either be found in one location through a "wraparound" delivery model or spread throughout different agencies and 
organizations that are service specific. Wraparound service delivery is the ideal model for settlement and integration services.

The wraparound model approach develops one case management plan for a client that covers all their needs in one organization. Typically, a centralized database is used to track a case management plan to coordinate the different services and workers who contribute to the plan. This coordination eliminates duplication of services but supports team collaboration to ensure a positive, wholistic outcome for the client. This approach leads to outcomes that are coordinated and meet the unique needs of each individual.

Here are two examples of how this model works:
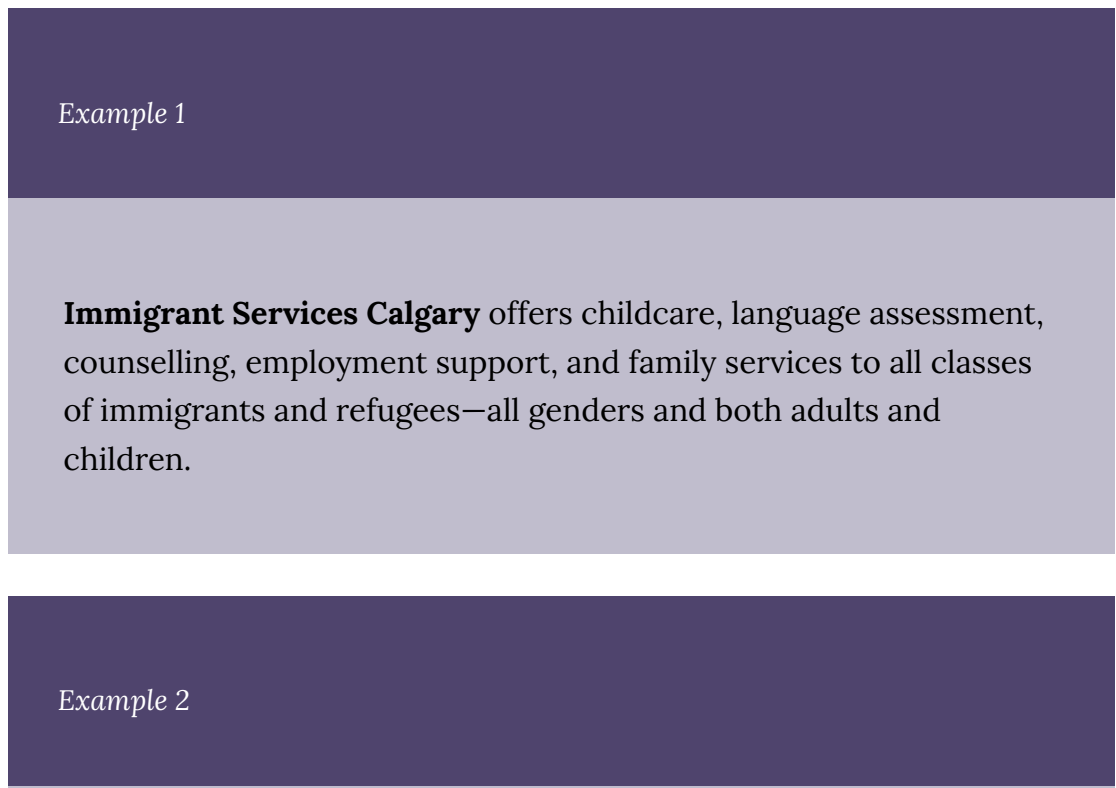

Calgary Immigrant Women's Association offers childcare, language training, counselling, legal services, employment training, and youth programs that are specific to immigrant women and their families.

Each organization has its unique mandate and may not have the capacity or financial resources to offer a broad range of services. An organization that primarily offers language or health services would refer a client to other agencies to get support for needs that can't be served within their organization. However, the trend in settlement 
service models is moving towards a wraparound service delivery model that responds to the wholistic needs of immigrants in one organization rather than multiple organizations.

The range of services offered by settlement agencies (Khan, 2020) in Canada are the following:

\section{Orientation}

2. Needs assessment

3. Job search

4. Employment services

5. Language training

6. Community connections
Gives an introduction to Canada to help manage the culture shock of arriving in a new country

Determines what kind of services an individual or family needs

Provides support to identify and connect with employment opportunities

Delivers workplace preparation programs to help with workplace communication and culture

Assesses language skills and places individuals in the appropriate level and type of language training courses (settlement language, conversation groups, job-specific language training, academic and professional bridging programs)

Provides social, professional (for example, IQUAS), and educational connections

Learning Activity 2: Research Newcomer Services

Go to the following websites and conduct a search according to your location:

- IRCC Website: Find free newcomer services near you

- IRCC Website: Welcome to Canada, What you should know publication

1. Research five (5) organizations in the province or community where you live.

2. Summarize the services that each organization offers and compare them to the "range of services" checklist above. 


\section{Evolution of Settlement Support Services}

Just as newcomers today reach out to family or friends as their first point of contact, newcomers did the same in the early 1900s. For newcomers arriving without family, reaching out to people who were from their own ethnic background provided a safe option for support and helped them to navigate the everyday life challenges for basic survival. Connecting with people from the same ethnic community afforded opportunities to communicate in a familiar language, practise their religion, and take part in cultural celebrations that helped ease the loneliness and isolation. Consequently, although this community support created familiarity, it also created isolation from the world outside their communities. Employment opportunities were primarily unskilled labour jobs in companies where people from their own ethnic communities worked.

Newcomers gravitated to housing locations where members from their ethnic communities lived. Although this created a safe and familiar environment, it insulated and isolated them from mainstream society. The term "enclave" (Hopper, 2012) is a term that best describes a community within a community where people from the same language, cultural, and religious background live and work within the broader mainstream community. English is typically learned on the job and not in a classroom. It is not unusual for people living in these communities to live in Canada for 20 to 30 years and not be able to communicate in English when venturing outside the home. In any major city in Canada, there are parts of the city that are referred to as Little Italy, Chinatown, the Jewish district, and so on. These terms reflect the legacy of early settlement patterns of immigration.

The following is an excerpt from a booklet called a History of Ethnic Enclaves in Canada (Zucchi, 2007) that gives a broader sense of the uniqueness of minority communities within communities from different periods in Canada's immigration history. 
"When we walk through Canadian cities nowadays, it is clear that ethnicity and multiculturalism are alive and well in many neighbourhoods from coast to coast. One need only amble through the gates on Fisgard Street in Victoria or in Gastown in Vancouver to encounter vibrant Chinatowns, or through small roadways just off Dundas Street in Toronto to happen upon enclaves of Portuguese from the Azores; if you wander through the Côte-des-Neiges district in Montreal, you will discover a polyethnic world-Kazakhis, Russian Jews, Vietnamese, Sri Lankans, or Haitians among many other groups-while parts of Dartmouth are home to an old African Canadian community. These neighbourhoods conjure up images of what an ethnic enclave might be, and our images have been led by personal glimpses of the neighbourhoods that all of us have known (if, indeed, we have not grown up in them). However, our notions of ethnic neighbourhoods have also been influenced (and some would say constructed) over the years by American perceptions of their own ethnic neighbourhoods and by governments, agencies, media reports, opinion leaders, and legislation regarding ethnic enclaves. In the late nineteenth century, for example, Canadian politicians and journalists worried about an immigrant tide that might gravitate to the cities and reproduce the tenements and slums of cities to the south.

Geographers have taught us that there is a strong connection between race and place and that the two help to define each other. Thus, when we discuss ethnic neighbourhoods or enclaves, it is important that we have some sense of what we mean by ethnicity. For our purposes, we will not restrict ourselves to the national connotations of the term, but to the sense of a common 'background' or history or sense of peoplehood, whether the common factor be nationality, Old World region or continent, race, religion, or any combination thereof. Sociologists have often alluded to the relationship between the persistence of ethnicity and the phenomenon of ethnic enclaves, and they have also examined the thorny questions regarding assimilation, integration, and acculturation since the pioneering work of the Chicago School of Sociology in the 1920s. One of the classic arguments has been that there is a link to residential segregation. With economic and social mobility, immigrants tend to leave enclaves and integrate with broader society, and within a couple of generations, we have full assimilation. Many other factors are of course involved, including the political context, intermarriage, networking, city size, and other local issues. In the last 30 years, there has been much debate among Canadian social scientists about the relevance of such terms as 'assimilation' in Canadian society. With the advent of multiculturalism in which there is no national identity to assimilate to, some sociologists argue that the term has limited meaning."

(Zucchi, 2007, p. 1) 
In Zucchi's 2007 booklet History of Ethnic Enclaves in Canada, there are case studies of different minority communities in major cities in Canada:

\section{Click to access the booklet}

On page 5 , paragraph 2 , there are some questions posed by the author that are presented for you to answer after reading this booklet:

- "How were these neighbourhoods formed? Why should they have emerged in the first place?"

Read the booklet and write a three- to five-paragraph response to these questions. Think in terms of how immigrants in these neighbourhoods benefited from living in these minority communities and how living in these communities benefited their settlement and integration into Canada.

Consider the difference between the terms "ghetto" and "enclave"; Zucchi (2007) favours "enclave."

1. What is the difference between the two terms?

2. Why is one term preferred over the other?

Post your response and start a dialogue with your peers. 


\section{Additional Resources}

In Canada. (2019, September 19). Challenges for new immigrants in Canada [Video]. YouTube. https://www.youtube.com/watch?v=kvPVkVyQNbo

Walker, B. (Ed.). (2008). The history of immigration and racism in Canada: Essential readings. Canadian Scholars Press.

Zucchi, J. (2007). Canada's ethnic group series: Booklet no. 31. A history of ethnic enclaves in Canada. Canadian Historical Association. https://cha-shc.ca/_uploads/ $\underline{5 c 374 f 720 f a 95 . p d f}$

44 | Settlement and Integration 


\section{Settlement Services Delivery Models: What Works}

Specific Learning Outcomes

By the end of this section, you will be able to

1. Categorize settlement service models throughout the history of immigration

2. Research and analyze the range of settlement service organizations in Alberta

3. Debate the value of these varying influences through discussions and in writing

Settlement services have gradually emerged and evolved from the informal support of familiar ethnic community and family groups to organized government-funded nonprofit services. The informal groups passed on what they learned from their immigrant experience. Organized government services provided a broader, professionally organized system of resources and support.

Learning Activity 4: Reflection

Watch the following video about the challenges of new immigrants in Canada and how they received settlement guidance and support from immigrant service organizations. 
After watching, answer the questions below. You can add these reflective responses to your chapter journal.

1. What are the challenges that Siraj outlines in this video?

2. What advice does he give as possible solutions to these challenges?

In Canada. (2019, September 19). Challenges for new immigrants in Canada [Video]. YouTube. https://www.youtube.com/watch?v=kvPVkVyQNbo

\section{Overview of Settlement Service Providers in Canada}

The following is a glossary of terms that are often used in the settlement sector: 
The information from the IRCC (Immigration, Refugee and Citizenship Canada) report, Evaluation of the Settlement Program (2017), reviews how settlement services have evolved since the early 1900s. The government has systemized the settlement sector by providing funding for the operation and delivery of settlement and integration services. Providers are closely monitored to ensure that services meet their stated outcomes and adhere to terms of the funding contract.

48 | Settlement Services Delivery Models: What Works 


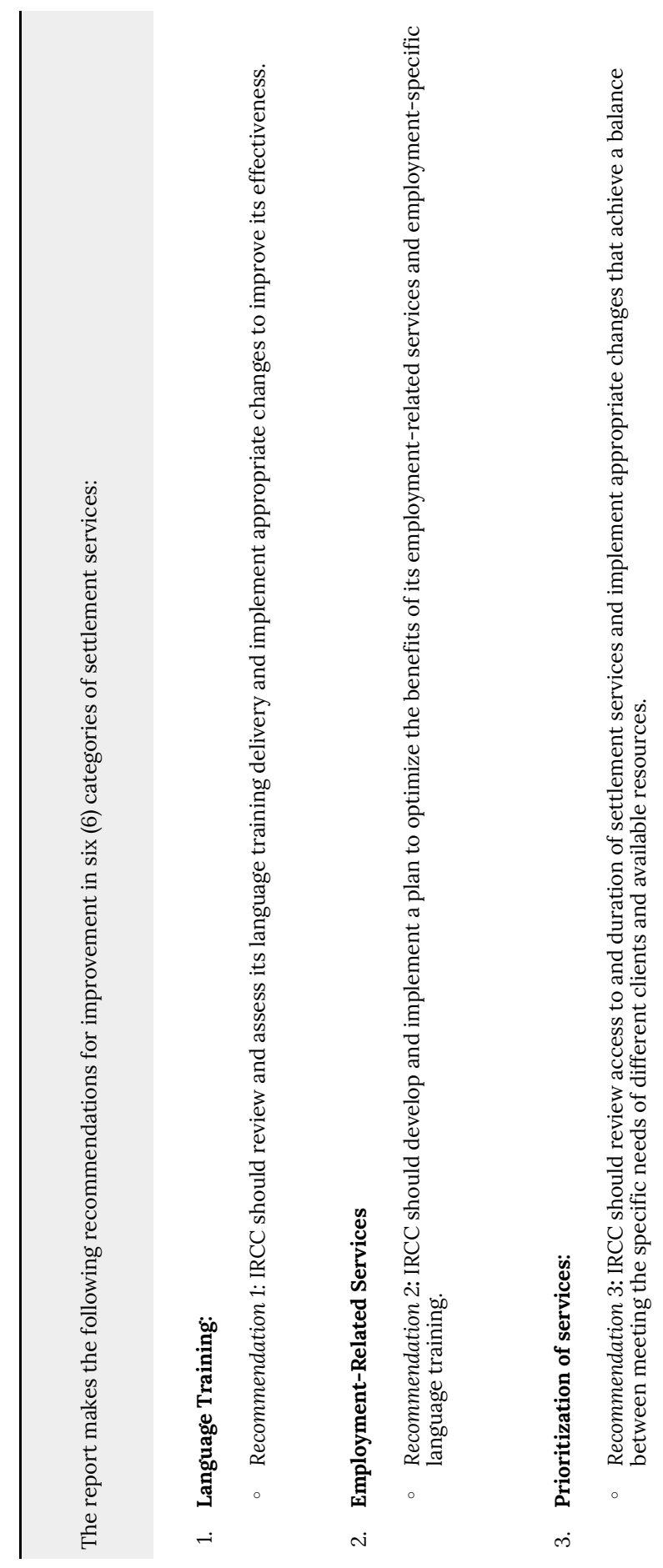




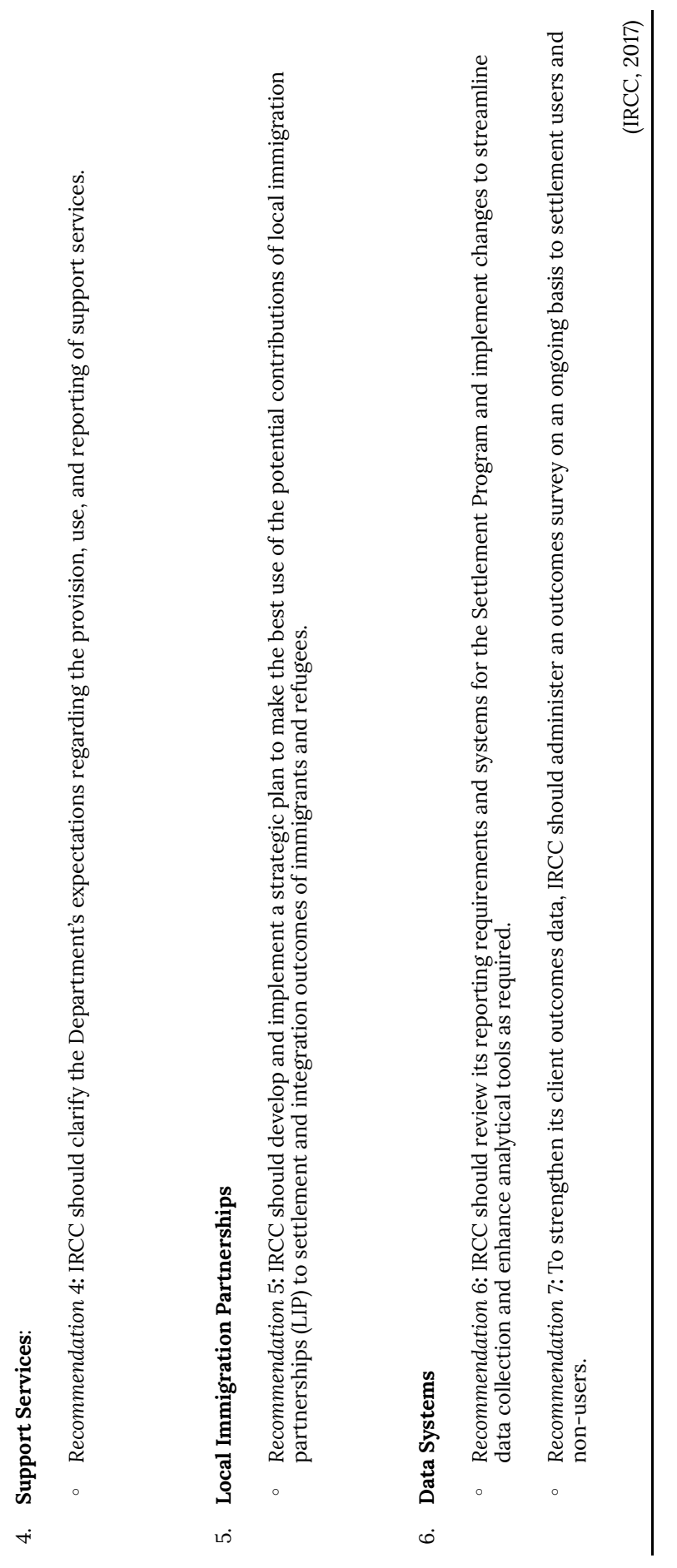


Immigrant settlement service organizations offer three types of services (Standing Committee on Citizenship and Immigration, 2010):

1. Direct Service Delivery: Through contribution agreements (CAs), IRCC funds service provider organizations (SPOs) such as immigrant-serving agencies, social service organizations, and educational institutions to provide their unique services to newcomers.

2. Support Services: In order to help address barriers that newcomers face in accessing settlement programming, IRCC funds six types of support services on a limited basis: Care for Newcomer Children, Translation, Transportation, Interpretation, Disability Support, and Crisis Counselling. It is expected that no more than $20 \%$ of the funding be used for direct services.

3. Indirect Services: Indirect services include projects that support the development of partnerships, capacity building, and the sharing of best practices among SPOs. Examples of indirect services include community partnerships and networks for local planning and settlement coordination. A local immigration partnership (LIP) is a partnership network that aims to coordinate services for newcomers at the local level by bringing together various stakeholders outside of traditional settlement service providers, including employers, school boards, health centres and networks, boards of trade, levels of government, professional associations, ethno-cultural organizations, faith-based organizations, and the community and social services sectors.

Learning Activity 5: Settlement Services Providers

The IRCC webpage "For new immigrants" provides a list of settlement service providers.

Choose five (5) different providers and identify the category of service in which they belong.

1. List the services they may be lacking.

2. Choose two (2) of the IRCC recommendations. Speculate on the reasons for these recommendations. Which two (2) recommendations do you think contribute the most to the positive integration of immigrants? 
Post your answer to the following question on the discussion forum:

- Which settlement service do you think has the biggest impact on a new immigrant's settlement process?

Respond to your classmates and generate a thought-provoking discussion. Remember to be respectful of others' opinions. You are learning from each other's diversity of ideas and perspectives.

\section{Additional Resources}

Broughton, S., \& Shield, J. (2020). Resilience and the immigrant settlement sector: A consideration of the place of accountability and performance management research report. York University. https://bmrc-irmu.info.yorku.ca/files/2020/04/ April-2020-Shields-Full-Report-FINAL.pdf?x82641https://bmrcirmu.info.yorku.ca/files/2020/04/April-2020-Shields-Full-ReportFINAL.pdf?x82641

George, U. (2002, July 1). A needs-based model for settlement service delivery for newcomers to Canada. International Social Work, 45(4), 465-480. https://doi.org/ $\underline{10.1177 / 00208728020450040501}$

Immigration, Refugees and Citizenship Canada. (2017). Evaluation of the settlement program. https://www.canada.ca/content/dam/ircc/documents/pdf/english/ evaluation/e2-2016-settlement-en.pdf

Ontario Council of Agencies Serving Immigrants. (2018). Foundations of settlement work in Ontario. https://settlementatwork.org/sites/settlementatwork.org/files/ Foundations\%20\%20of\%20Settlement\%20Work\%20in\%20Ontario.pdf

Standing Committee on Citizenship and Immigration. (2019). Improving settlement services across Canada report. 42nd Parliament, 1st session. https://www.ourcommons.ca/DocumentViewer/en/42-1/CIMM/report-26/ 


\section{Immigrant and Refugee Historical Settlement Needs}

Specific Learning Outcomes

By the end of this section, you will be able to

1. Identify the historical challenges of diverse groups of immigrants and refugees

2. Compare the differences and similarities of the immigrant and refugee groups that are served by organizations in the settlement sector

3. Recommend the types of service delivery practices that meet the unique needs of different groups of immigrants and refugees

\section{Understanding Your Client Group: Immigrant Stories}




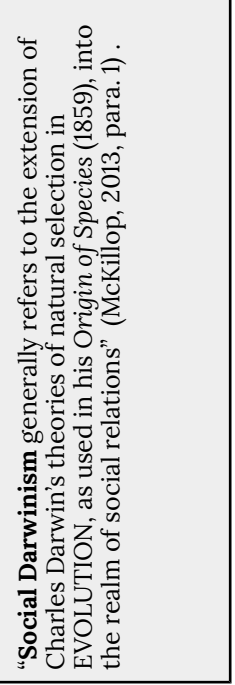


A vital part of being a settlement practitioner is to become familiar with the unique settlement needs of immigrant and refugee groups throughout the history of immigration in Canada. Many of the settlement needs are similar, such as housing, language learning, childcare, and employment, but other needs are unique to each group because of cultural and religious-specific practices, beliefs, and values that impede intercultural communication and fitting into mainstream culture. It is also vital to understand underlying social values, beliefs, and ideologies such as Social Darwinism that promote the belief that some races are superior to others, specifically the white race. Social Darwinism was originally a biological scientific theory applied to evolution. This theory turned into a social ideology that was used in politics and society to rationalize blocking non-white people from white society. This early 20thcentury social theory influenced how immigrants and refugees were perceived and consequently influenced Canada's early immigration policies (McKillop, 2013)

Attitudes and ideology are embedded into the morality and values of different periods of time throughout history, but they are not necessarily reflective of the values and morals of modern-day Canada. What was considered acceptable thought as recently as the 1990's, is now considered abhorrent and out of touch with the values and morals of today. For example, the passage of the Indian Act and the existence of Indian Residential Schools in Canada was originally justified by high-ranking officials within the Canadian government as facilitating the integration of Indigenous communities into Canadian society and forcing the adoption of European and Christian value systems (Canadian Encyclopedia, 2021). Unfortunately, this was not the case, as we now know that residential schools destroyed Indigenous ways of thinking, being and knowing, caused great harm to generations of Indigenous Peoples, and sought to "kill the Indian in the child" (Coyne, 2021).

NOTE: There have been numerous terms that have been used to refer to Indigenous Peoples in Canada over the course of Canadian history. For more information on the evolution of these terms, please visit the Pulling Together: Foundations Guide.

Learning Activity 6: Immigration Milestones

Review the timelines in "Canada's Immigration History: Milestones and Stories" earlier in this chapter. Reflect on the following questions:

1. From which countries did the first major groups of immigrants 
originate?

2. What precipitated the peak in immigration in the early 1900 s?

3. At what points in history were refugees welcomed into Canada? Which countries did they come from?

4. When did the first Sikh immigrants come to Canada? Did Canada continue to encourage immigration South Asian countries?

5. When did Canada open immigration to non-European countries?

Write a summary of your observations in your chapter journal.

\section{Immigrant Stories}

Learning Activity 7: Passages Canada Video

Passages Canada is a Canadian government publication that introduces immigrants to Canada.

Watch the video below and answer the following questions:

1. What are some of the stereotypes and misconceptions about immigrants?

2. Why is it important to hear about immigrant stories?

3. What are some of the benefits that result from sharing immigrant stories?

4. What are three (3) major challenges for immigrants that are identified in this video? 
One or more interactive elements has been excluded from this version of the text. You can view them online here:

https://openeducationalberta.ca/settlement/?p=206\#oembed-1

New Canadians. (2018, October 26). Passages Canada introduces today's immigrants to Canada [Video]. YouTube. https://www.youtube.com/watch?v=jEIw_gwDoDE

Learning Activity 8: Immigrant Story Videos

Choose three (3) of the following immigrant story videos and answer the following questions:

1. Where are the immigrants from?

2. Why did they want to immigrate to Canada?

3. How did they prepare themselves to immigrate to Canada?

4. What were their initial challenges?

5. What settlement services did they access.?

6. How did they explain what it means to be Canadian?

7. What do they believe Canada will be like in 30 years?

8. What advice do they have for newcomers to Canada?

9. After watching all three videos, describe the common elements of the immigrants' experiences.

10. What kinds of support or services would you have recommended?

11. How do you think that hearing immigrant stories will help you with your development as a settlement services practitioner? 
Video I

One or more interactive elements has been excluded from this version of the text. You can view them online here:

https://openeducationalberta.ca/settlement/?p=206\#oembed-2

Historica Canada. (2017, June 19). Heritage minutes: "Boat people" refugees [Video]. YouTube. https://www.youtube.com/watch?v=v4nKkqdnVCM

Video 2

CBC. (2017, June 4). The Canadian experiment | Canada: The story of us, full episode 10 [Video]. YouTube. https://www.youtube.com/watch?v=-ePe1EjxB7o

\section{Video 3}

One or more interactive elements has been excluded from this version of the text. You can view them online here:

https://openeducationalberta.ca/settlement/?p=206\#oembed-3

One or more interactive elements has been excluded from this version of the text. You can view them online here:

https://openeducationalberta.ca/settlement/?p=206\#oembed-4

Fifth Estate. (2017, March 20). After the crossing : Refugees in Canada - The Fifth Estate [Video]. YouTube. https://www.youtube.com/watch?v=8ba45eXFBW8 
Video 4

One or more interactive elements has been excluded from this version of the text. You can view them online here:

https://openeducationalberta.ca/settlement/?p=206\#oembed-5

Wanders of Chi. ( 2020, June 27). My Canadian immigration story: Why I decided to move to Canada permanently [Video]. YouTube. https://www.youtube.com/watch?v=V2FuzQ6e6xU

Video 5

One or more interactive elements has been excluded from this version of the text. You can view them online here:

https://openeducationalberta.ca/settlement/?p=206\#oembed-6

TEDx Talks. (2018, July 16). What did two years in Canada teach me? [Video]. YouTube. https://www.youtube.com/watch?v=G4nJwLBllDM

\section{Video 6}

One or more interactive elements has been excluded from this version of the text. You can view them online here:

https://openeducationalberta.ca/settlement/?p=206\#oembed-7

Arienne - SeeYouSoon Travel. (2018, May 10). Halifax's Pier 21 and my family's immigration story | Nova Scotia [Video]. YouTube. https://www.youtube.com/watch?v=-LjZ0-blNho 
One or more interactive elements has been excluded from this version of the text. You can view them online here:

https://openeducationalberta.ca/settlement/?p=206\#oembed-8

Historica Canada. (2015, May 20). Jason's story: Embracing the hyphen in Korean-Canadian [Video]. YouTube. https://www.youtube.com/watch?v=IBaWoeXE5Uc

\section{Additional Suggested Resources}

Canadian Heritage. (2017, April 21). Remembering the journey to Canada of Vietnamese refugees - Asian heritage month. [Video]. YouTube. https://youtu.be/rGPbCUj7s0I

Canadian Immigration Channel. (2017, May 28). Do not use settlement services. Immigration to Canada. LP Group [Video]. YouTube. https://www.youtube.com/ watch?v=dyZBslW4XIE

El-Assal, K. (2020, June 14). Where are Canada's immigrants coming from in 2020 ? CIC News. https://www.cicnews.com/2020/06/where-are-canadas-immigrantscoming-from-in-2020-0614659.html

Walker, B. (Ed.). (2008). The history of immigration and racism in Canada: Essential readings. Canadian Scholars Press.

Wilkinson, L., Bhattacharyya, P., Riziki, A., \& Abdul-Karim, A. (2019). Yazidi resettlement in Canada-final report 2018. University of Manitoba. https://umanitoba.ca/ faculties/arts/research/media/YAZIDI_FINAL_FEB14_2019.pdf

60 Immigrant and Refugee Historical Settlement Needs 


\section{Perspectives on the Value of Settlement Services}

Specific Learning Outcomes

By the end of this section, you will be able to

1. Identify the different social perspectives about immigration and settlement services throughout the milestones of immigration

2. Research how settlement services are perceived in the media today

3. Identify what immigrants and refugees say about their experiences with settlement services

Settlement services have gone from the kitchen table to the strip mall storefront or downtown office tower. In the 1970s, there was minimal funding, so services were carried out by volunteers with small local civic grants to support their grassroots operations. The early practice of kitchen table advice was a volunteer endeavour. As the settlement sector became more organized and professional, the availability funds from the private sector and from government expanded the resources available to both service providers and clients.

The additional resources brought more stability into the settlement services sector and created opportunities to develop needs-specific programs. Trained settlement workers were hired who had specializations in education, job training, counselling, interpreting services, family parenting, literacy, childcare services, legal services, and financial literacy. Immigrant settlement service providers became sources of employment for immigrants who had successfully navigated the immigrant experience and wanted to mentor and support new immigrants through their settlement journey.

Innovation in service delivery is now a critical focus of some of the large and established immigrant organizations that started out as grassroots, volunteer-driven 
organizations working out of community-based premises such as church basements. Service provider organizations (SPOs) such as Calgary Catholic Immigration Services, the Edmonton Mennonite Centre for Newcomers, the Immigrant Services Association of Nova Scotia (ISANS), and Immigrant Services Calgary developed best practices over the years that improved service delivery and led to better outcomes for their immigrant clients. Click here to view a newspaper article and video from the Calgary Herald that shows how Immigrant Services Calgary has changed its delivery model to better meet the evolving needs of immigrants.

The innovation that Immigrant Services Calgary (ISC) (Babych, 2020) has embraced is an integrated services model (Community Development Council Durham, 2010), a type of one-stop shop where a range of services is housed in one location in addition to having partnerships with services outside the organization that can't be provided inhouse. For example, although many SPOs offer childcare services, in-house they often don't have internal expertise to work with children with disabilities, so diagnostic services are accessed through formal or informal partnerships with organizations such as Pace Kids and Alberta Children's Services.

Learning Activity 9: The Value of Settlement Services

Watch the following video and reflect on the following questions:

1. What is the benefit of having settlement services housed within one organization?

2. Would it be better to have privately owned immigration services or government-supported immigrant settlement services?

3. Is it the responsibility of the immigrant to pay for a private service or should it be the responsibility of the government to provide free settlement and integration services to immigrants and refugees? Scepticism about governmentsupported free services is expressed in the video.

4. What concerns are expressed about settlement services? Summarize the concerns.

5. What is the case for immigrants to not using settlement 
services?

6. What is your rebuttal? Do you agree or disagree? Why?

Write your reflections in your chapter journal.

D. One or more interactive elements has been excluded from this version of the text. You can view them online here:

https://openeducationalberta.ca/settlement/?p=208\#oembed-1

Canadian Immigration Channel. (2017, May 28). Do not use settlement services. Immigration to Canada. LP Group [Video]. YouTube. https://www.youtube.com/watch?v=dyZBslW4XIE 


\section{Non-Profit Organizations that Support Settlement Sector Practitioners}

The Ontario Council of Agencies Serving Immigrants (OCASI) was established in 1978 and is one of several agencies in Canada that support the professional development of settlement practitioners through research about immigration issues and best practices. The Alberta Association of Immigrant Serving Agencies (AAISA) is the Alberta counterpart to OCASI. AAISA has a similar mandate-to build the capacity of immigrant-serving agency practitioners through research and training. The manual Foundations of Settlement Work in Ontario (OSCASI, 2018) is a valuable resource for settlement practitioners. Although it references settlement work in Ontario, the best practices outlined are universal and relevant for settlement practitioners in any area of Canada.

Learning Activity 10: Reading

Read the directed sections of the Foundations of Settlement Work in Ontario manual and reflect on the following:

1. Read Chapter 6, pages 123 to 140.

2. On page 123, you will find section 4 of Chapter 6 , "How Services Are Delivered." This section explains how settlement agency programs and services are funded and the accountability requirements for that funding.

Accountability is about tracking and accounting for the use of funds, as well as measuring service delivery outcomes that adhere to the "principles and values" for the settlement sector. 


\section{Principles and Values of the Sector}

People who work in the immigrant- and refugee-serving sector are expected to uphold certain principles and values. The first chapter of the Foundations of Settlement Work in Ontario training guide covers several of these in more depth. As part of the settlement renewal process, the Canadian Council for Refugees published a policy document about best settlement practices. This document identifies the following core values for the sector:

1. Access

2. Inclusion

3. Client empowerment

4. User-defined services

5. Holistic approach

6. Respect for the individual

7. Cultural sensitivity

8. Community development

9. Collaboration

10. Accountability

11. Orientation towards positive change

12. Reliability (trustworthiness)

Research two (2) immigrant-serving agencies. Review the agency websites and answer the following questions:

1. What makes the agency unique?

2. What is the agency's model for service delivery? What range 
of services does it offer?

3. Comment on what is unique or innovative about the agency's service delivery.

4. Do the agency's values and principles align with the principles and values identified in the OCASI document?

5. Is this an agency that you would like to work for? Explain why or why not.

Write your answers and reflections in your chapter journal. 


\section{Conclusion}

This chapter has given you an overview of the history of settlement in Canada that presents historical data as well as context for that data. This chapter gives you underlying reference points that will help them understand how the settlement and integration sector has evolved in response to the evolving sociopolitical factors over a period of 150 years. The sociopolitical milestones during this time have influenced the best practices in the settlement sector.

Key Takeaways

The following is a summary of the learnings from this chapter:

1. Canada was a land of Indigenous Peoples long before it was officially "discovered" in 1497 by Giovanni Caboto, an Italian explored who named the "New Land." Caboto discovered the New Land when he decided to travel west to China instead of east.

2. Canada was a furtrading destination for the Hudson's Bay Company in the 1600s. The fur trade initiated the settlement of English and French colonists from European countries.

3. Canada's growth and immigration started in the late 1800 s and early 1900s to help with the economic growth in industry, agriculture, and infrastructure.

4. There are three milestones in immigration history that were based on geopolitical trends and social theories:

- The early 1900s favoured immigrants from white European countries and discouraged non-white immigrants. The Chinese head tax was a historical example of systemic racism during that time. Non-white Europeans were seen as cheap labour and were not eligible for permanent residency. During this time, there 
were two additional groups of non-white immigrants who came to Canada illegally and who were allowed to stay as sources of labour- former British soldiers from the Punjab and Japanese men who arrived as stowaways from Japan.

- The second milestone covered a period that brought immigrants affected by overseas political strife in European countries during and after World War II. Canada's allied support resulted in the internment of Canadians from countries that were at war with Canada's allies-Britain, France, and the United States. Consequently, in support of these allies, Canada interned German, Italian, and Japanese Canadians out of fear of in-country alliances with enemy countries such as Germany, Italy, and Japan.

- The third milestone reflected a new wave of social consciousness in the 1960s and 1970s that eliminated discrimination against non-European immigrants. At this time, Canada opened its borders to refugees from all countries. Canada also was the first country in the world to create a fair and objective point system that used eligibility criteria based on the needs of the economy and eliminated biased criteria based on race.

5. The settlement sector grew in capacity parallel to the establishment of systematic government oversight of the immigration system. The sector has built a body of research and knowledge that informs the evolving best practices of settlement and integration service providers.

In summary, this chapter provides examples of how far the settlement services sector has evolved throughout the history of immigration. As a result of the learnings throughout the different milestones in social and political ideology, the sector has been professionalized and has acknowledged that there is unique knowledge, competencies, and expertise required by practitioners in the settlement sector. 


\section{Chapter References and Attributions}

\section{References}

Babych, S. (2020, September 23). Innovative system introduced in Calgary to improve newcomers' access to settlement services. Calgary Herald. https://calgaryherald.com/news/local-news/innovative-system-introduced-incalgary-to-improve-newcomers-access-to-settlement-services

Bicha, K. D. (1965, December 10). The Plains Farmer and the Prairie Province Frontier, 1897-1914. Proceedings of the American Philosophical Society, 109(6), 398-440. http://www.jstor.org/stable/986139

Biography. (2020). John Cabot. https://www.biography.com/explorer/john-cabot

Brydon, A. (1999). Icelanders. In P. R. Magocsi (Ed.), Encyclopedia of Canada's peoples (pp. 685-700). Multicultural History Society of Ontario and University of Toronto Press.

Calgary Catholic Immigration Services (CCIS). (2021). Homepage. https://www.ccisab.ca/

Cameron, J. D. (2005). Canada's struggle with illegal entry on its west coast: The case of Fred Yoshy and Japanese migrants before the Second World War. BC Studies, 146, 37-62. https://doi.org/10.14288/bcs.v0i146.1757

Campbell Cohen Law Firm. (2021, June 25). Canada immigration levels plan 2021-2023. CanadaVisa. $\quad$ https://www.canadavisa.com/canada-immigration-levelsplans.html\#gs.4hwnut

Canadian Encyclopedia. (2021). Timeline: Residential schools. https://www.thecanadianencyclopedia.ca/en/timeline/residential-schools

Canadian Encyclopedia. (2016). Asian heritage in Canada. https://www.thecanadianencyclopedia.ca/en/article/asian-heritage-in-canada-1

Canadian Museum of History. (n.d.). The struggle for Canada. https://www.historymuseum.ca/history-hall/struggle-for-canada

Columbus Centre. (n.d.). The internment camps. Italian Canadians as Enemy Aliens: Memories of World War II. http://www.italiancanadianww2.ca/theme/detail/ internment camps 
Community Development Council Durham. (2010). Towards an integrated immigrant services delivery system in Durham region: Research and considerations for moving forward. $\quad$ https://www.cdcd.org/wp-content/uploads/2015/06/CDCDAug-2010.pdf

Conway, S. (2018). From Britishness to multiculturalism: Official Canadian identity in the 1960s. Canadian Studies, 84(2), 9-30. https://doi.org/10.4000/eccs.1118

Coyne, A. (2021, June 4). The shame of residential schools must be worn by us all not just historical figures. The Globe and Mail. https://www.theglobeandmail.com/ opinion/article-the-shame-of-residential-schools-must-be-worn-by-us-all-notjust/

Edmonton Mennonite Centre for Newcomers (EMCN). (n.d.). Homepage. http://www.emcn.ab.ca/

El-Assal, K. (2020, June 14). Where are Canada's immigrants coming from in 2020 ? CIC News. https://www.cicnews.com/2020/06/where-are-canadas-immigrantscoming-from-in-2020-0614659.html

El-Assal, K., \& Thevenot, S. (2020, 30 October). Canada to target over 400,000 immigrants per year. CIC News. https://www.cicnews.com/2020/10/canada-torelease-2021-2023-immigration-levels-plan-1016133.html\#gs.4hw7u7

Geography Open Textbook Collective. (2014). Case study 1: The Indian residential school system. In British Columbia in a global context. https://opentextbc.ca/ geography/chapter/4-4-case-study/

George, U. (2002). A needs-based model for settlement service delivery for newcomers to Canada. International Social Work, 45(4), 465-480. https://doi.org/10.1177/ $\underline{00208728020450040501}$

Government of Canada. (2021a). Get help before arriving in Canada: About pre-arrival services. https://www.canada.ca/en/immigration-refugees-citizenship/services/ new-immigrants/new-life-canada/pre-arrival-services.html

Government of Canada. (2021b). Notice - Supplementary information for 2021-2023 Immigration Levels Plan. https://www.canada.ca/en/immigration-refugeescitizenship/news/notices/supplementary-immigration-levels-2021-2023.html

Griffith, A. (2017, November 1). Building a mosaic: The evolution of Canada's approach to immigrant integration. Online Journal of the Migration Policy Institute. https://www.migrationpolicy.org/article/building-mosaic-evolution-canadasapproach-immigrant-integration

Griffith, A. (2015, September 22). Multiculturalism in Canada: Evidence and anecdote. 
Policy Options. https://policyoptions.irpp.org/2015/09/22/multiculturalism-incanada-evidence-and-anecdote/

Hopper, T. (2012, February 11). Canada: As immigration booms, ethnic enclaves swell and segregate. National Post. https://nationalpost.com/news/canada/canada-asimmigration-booms-ethnic-enclaves-swell-and-segregate

Immigrant Services Association of Nova Scotia (ISANS). (2021). Homepage. https://www.isans.ca/

Immigrant Services Calgary. (2021). Homepage. https://www.immigrantservicescalgary.ca/

Immigration, Refugees and Citizenship Canada. (2017). Evaluation of the settlement program. https://www.canada.ca/content/dam/ircc/documents/pdf/english/ evaluation/e2-2016-settlement-en.pdf

Jiro, N. (1998). Phantom immigrants: Oikawa Jinsaburo, the Suian Maru, and the Miyagiken Japanese-Canadians of Lion Island and Don Island (D. Sulz, Trans.). David Sulz. (Original work published 1979). https://sites.ualberta.ca/ sulz/ Phantom Immigrants Oct09.pdf

Khan, Z. (2020, February 27). What services do settlement agencies provide in Canada? World Education Services. https://www.wes.org/advisor-blog/settlementagencies-services-canada/

Lee, K. L. (2017, June 29). 'Humiliation Day': July 1 has added meaning for some Chinese Canadians. CBC. https://www.cbc.ca/news/canada/nova-scotia/humiliation$\underline{\text { day-chinese-canadian-head-tax-exclusion-act-july-1-1.4175025 }}$

McKillop, A. B. (2013, December 16). Social Darwinism. The Canadian Encyclopedia. https://www.thecanadianencyclopedia.ca/en/article/social-darwinism

McRae, M. (2021). The Chinese head tax and the Chinese Exclusion Act. Canadian Museum for Human Rights. https://humanrights.ca/story/the-chinese-head-taxand-the-chinese-exclusion-act

Mishra, S. (2020, May 6). 10 things to do after landing in Canada as a PR. AM22Tech. https://www.am22tech.com/ca/things-to-do-after-landing-in-canada-pr/

O'Neil, A. (2020, July 20). Population of Canada 1800-2020. Statista. https://www.statista.com/statistics/1066836/population-canada-since-1800/

Ontario Council of Agencies Serving Immigrants (OCASI). (2018). Foundations of settlement work in Ontario. https://settlementatwork.org/sites/ settlementatwork.org/files/

Foundations\%20\%20of\%20Settlement\%20Work\%20in\%20Ontario.pdf 
Roy, P. E. (2020, June 11). Internment in Canada. The Canadian Encyclopedia. https://www.thecanadianencyclopedia.ca/en/article/internment

Saint-jacques, B., Chambers, J. K., \& Cooper, C. (2019, October 18). Immigrant languages in Canada. The Canadian Encyclopedia. https://www.thecanadianencyclopedia.ca/ en/article/ethnic-languages

Standing Committee on Citizenship and Immigration. (2019, June). Improving settlement services across Canada: Report of the Standing Committee on Citizenship and Immigration. House of Commons Canada. https://www.ourcommons.ca/ DocumentViewer/en/42-1/CIMM/report-26/

Standing Committee on Citizenship and Immigration. (2010, March). Best practices in settlement services: Report of the Standing Committee on Citizenship and Immigration. House of Commons Canada. https://www.ourcommons.ca/Content/ Committee/403/CIMM/Reports/RP4388396/cimmrp02/cimmrp02-e.pdf

Statistics Canada. (2016). 150 years of immigration in Canada. https://www150.statcan.gc.ca/n1/pub/11-630-x/11-630-x2016006-eng.htm

Sulz, D. K. A. (2003). Japanese "entrepreneur" on the Fraser River: Oikawa Jinsaburo and the illegal immigrants of the Suian Maru [Master's thesis, University of Victoria]. https://sites.ualberta.ca/ sulz/ SulzThesis_Japanese_Entrepreneur_on_the_Fraser_River.pdf

Troper, H. (2021). Immigration to Canada. The Canadian Encyclopedia. https://www.thecanadianencyclopedia.ca/en/article/immigration

University of the Fraser Valley. (2021). History of South Asians in Canada: Timeline. South Asian Studies Institute. https://www.southasiancanadianheritage.ca/ history-of-south-asians-in-canada/

Walker, B. (Ed.). (2008). The history of immigration and racism in Canada: Essential readings. Canadian Scholars Press.

Whitaker, R. (1991). Canadian immigration policy since Confederation. Canada's Ethnic Groups series: Booklet no. 15. Canadian Historical Association. https://chashc.ca/ uploads/5c374d81cca15.pdf

Widdis, R. W. (1992). Saskatchewan bound: Immigration to a new Canadian frontier. Great Plains Quarterly, 12(4), 254-268. http://digitalcommons.unl.edu/ greatplainsquarterly/649

Wilkinson, L., Bhattacharyya, P., Riziki, A., \& Abdul-Karim, A. (2019). Yazidi resettlement in Canada - Final report 2018. University of Manitoba. https://umanitoba.ca/ faculties/arts/research/media/YAZIDI FINAL FEB14 2019.pdf 
Wilson, K. (2018). Pulling Together: Foundations Guide. Victoria, BC: BCcampus. Retrieved from https://opentextbc.ca/indigenizationfoundations/

Zucchi, J. (2007). A history of ethnic enclaves in Canada. Canada's Ethnic Groups series: Booklet no. 31. Canadian Historical Association. https://cha-shc.ca/ uploads/ $\underline{5 \mathrm{c} 374 \mathrm{f} 720 \mathrm{fa} 95 . p d f}$

\section{Media Attributions}

Arienne - SeeYouSoon Travel. (2018, May 10). Halifax's Pier 21 and my family's immigration story | Nova Scotia [Video]. YouTube. https://www.youtube.com/ watch?v=-LjZ0-blNho

Canadian Heritage. (2017, April 21). Remembering the journey to Canada of Vietnamese refugees - Asian heritage month. [Video]. YouTube. https://youtu.be/rGPbCUj7s0I

Canadian Immigration Channel. (2017, May 28). Do not use settlement services. Immigration to Canada. LP Group [Video]. YouTube. https://www.youtube.com/ watch?v=dyZBslW4XIE

CBC. (2017, April 9). Hunting treasure / Canada: The story of us, full episode 2. [Video]. YouTube. https://www.youtube.com/watch?v=Q8rheibq-nM

CBC. (2017, June 4). The Canadian experiment | Canada: The story of us, full episode 10 [Video]. YouTube. https://www.youtube.com/watch?v=-ePe1EjxB7o

The Fifth Estate. (2017, August 25). Japanese deportations in Canada during WWII: Throwaway citizens (1995) - The Fifth Estate [Video]. YouTube. https://www.youtube.com/watch?v=ggNYkFg6AjA

The Fifth Estate. (2017, March 20). After the crossing: Refugees in Canada - The Fifth Estate [Video]. YouTube. https://www.youtube.com/watch?v=8ba45eXFBW8

Historica Canada. (2015, May 20). Jason's story: Embracing the hyphen in KoreanCanadian [Video]. YouTube. https://www.youtube.com/watch?v=IBaWoeXE5Uc

Historica Canada. (2017, June 19). Heritage minutes: "Boat people" refugees [Video]. YouTube. https://www.youtube.com/watch?v=v4nKkqdnVCM

In Canada. (2019, September 19). Challenges for new immigrants in Canada [Video]. YouTube. https://www.youtube.com/watch?v=kvPVkVyQNbo

New Canadians. (2018, October 26). Passages Canada introduces today's immigrants to Canada [Video]. YouTube. https://www.youtube.com/watch?v=jEIw gwDoDE 
Sidhu, S. (2014, September 16). We are not strangers documentary about 1907 Bellingham riots [Video]. YouTube. https://www.youtube.com/watch?v=mvn_LpXj694\&t=306s

Storyhive. (2017, May 19). The surprising story of Canada's enemy aliens. [Video]. YouTube. https://www.youtube.com/watch?v=UY4vTBQTpUA\&t=20s

TEDx Talks. (2018, July 16). What did two years in Canada teach me? [Video]. YouTube. https://www.youtube.com/watch?v=G4nJwLBllDM

TEDx Talks. (2013, October 23). The big shift - Understanding the new Canadian: Darrell Bricker at TedxToronto [Video]. YouTube. https://www.youtube.com/ watch?v=nquKRW7W78I

TEDx Talks. (2013, July 16). Why Canadian history isn't as boring as you think it is: Chris Turner at TEDxYYC [Video]. YouTube. https://www.youtube.com/ watch? $=\mathrm{CBPvQRazhw8}$

University of British Columbia. (2016, June 15). An act of grace: UBC's first Sikh immigrant family [Video]. YouTube. https://www.youtube.com/ watch?v=IUcn8olejWs

The Wanders of Chi. (2020, June 27). My Canadian immigration story: Why I decided to move to Canada permanently [Video]. YouTube. https://www.youtube.com/ watch?v=V2FuzQ6e6xU 


\section{CHAPTER 2: SOCIAL JUSTICE IN SETTLEMENT WORK}





\title{
Introduction
}

\author{
ALEXANDRU CALDARARU
}

The concept of social justice is foundational to effective settlement work practice. Although there are many different definitions of social justice, most of them imply that people have equal rights and equitable opportunities in the communities in which they live and work. More specifically, social justice refers to the fair and compassionate distribution of the fruits of economic growth. This implies that such growth be not only sustainable in the short term, but that it also facilitate the use of economic resources for future generations of humans in a manner that does not place undue stress or harm on natural environments (International Forum for Social Development, 2006, p. 7).

This definition becomes all the more important for settlement workers to consider when one examines recent statistics on migration to Canada. For the period ending December 31, 2019, Immigration Refugees and Citizenship Canada (2020) reported that over 341,000 permanent residents were welcomed into the country, over 402,000 study permits were issued, and over 404,000 temporary work permits were granted. When one considers that approximately $58 \%$ of all permanent residents were admitted as economic migrants, that more than two-thirds of prospective international students intend to permanently move to Canada upon graduation (Esses et al., 2018, p. 3), and that in 2018, $46 \%$ of new economic immigrants were former temporary foreign workers (Statistics Canada, 2020), the link between the economic rights and opportunities afforded to newcomers in their host countries and their successful integration becomes all the more apparent.

As will be discussed below, settlement workers often play an unacknowledged teaching role in the lives of the people they support, and it is of vital importance that workers approach this role with a thorough understanding of the current and historical complexities of life in a multicultural, settler colonial society. 
By the end of this chapter, you should be able to

1. Define the terms social justice, anti-oppressive practice, common sense knowledge, and the Great Canadian Myth

2. Identify the links between the Great Canadian Myth and struggles for social justice in Canada.

3. Discuss examples of anti-racism/anti-colonialism social movements and their relevance to social justice and effective settlement work practice

4. Discuss the importance of deconstructing common-sense knowledge in effective settlement work practice

5. Describe how anti-oppressive practice can help develop a social justice orientation in settlement work practice

On your own, take a few minutes to identify five or six values you associate with being "Canadian."

1. Where did you learn these values from?

2. When did you learn them?

3. How did you learn them?

4. How do you feel when you perceive the violation of these values? Why?

Keep this list handy because a similar question will be asked of you again at the end of this chapter.

\section{INSTRUCTOR NOTE}

Although this activity can work well in an in-person think-pair- 
share format, it could also work well as an online discussion forum topic. 


\section{Multiculturalism and Myth-Making in Canada}

\section{The Great American (Meritocratic) Myth}

Many people born and raised in Canada are familiar with the concept of the "American dream" and its twin concept, meritocracy. Alvarado (2010) contends that central to the American dream is the idea that the United States is a meritocracy (or country of boundless opportunity), and that people have the opportunity to succeed based on their own merit, which is loosely defined to include a person's abilities, work ethic, attitude, and integrity (p. 12).

Although the concept of meritocracy can appeal to a person's sense of responsibility for their own success, the opposite is also true. If one were to consider that they have equal opportunities for success in life, then they would recognize that they are chiefly responsible for their failures as well. The danger embedded within the idea of meritocracy lies in the obscuring of structural barriers that can prevent people from reaching their full potential and lead them to develop an internalized negative selfworth, one where they feel they "deserve" to fail (Collier, 2018, p. 5).

This danger becomes more apparent when one considers the following statistics on race and poverty in the United States. In the United States, Indigenous peoples have a poverty rate that is roughly two and a half times higher than it is for white people, followed closely by Black individuals and people who are Latin American (or Latinx) (Kaiser Family Foundation, 2021). Almost three-quarters of white people own their own homes, but less than half of Latinx and Black Americans do (Statistia, 2020), and Black Americans are approximately five times as likely to be incarcerated as white Americans are (Nellis, 2016). Finally, Black Americans on average have a life expectancy that is four years shorter than it is for white Americans (Arias \& Xu, 2020). 
Although it would be unreasonable to argue that such statistical disparities could be the result of personal choices that lead to failures alone, meritocratic narratives assume equal opportunity for all, and therefore do not leave room for discussion on how factors such as a person's race/ethnicity, gender, sexual orientation, or class can limit an individual's opportunities for success. This has the effect of ensuring that the American dream remains a myth (although a powerful one) in discussions regarding social justice in the United States.

\section{The Great Canadian (Multicultural) Myth}

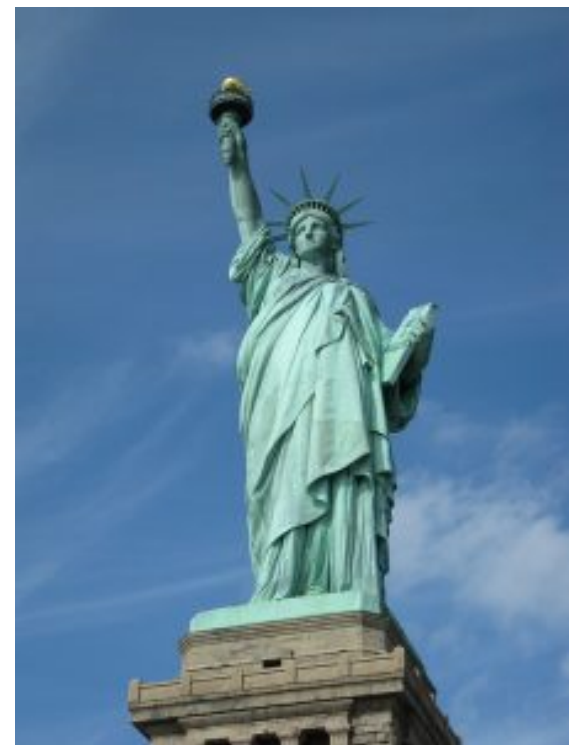

Statue of Liberty in New York City

Although it may seem strange to devote an appreciable amount of time towards a discussion of myth-making in American society, such conversations are vital for settlement workers in Canada to be cognizant of. Such myths offer important insights into the powerful assumptions that lie at the heart of Canadian society-assumptions that are instrumental in the construction of what people think it means to be Canadian.

For example, Millar (2017) contends that we have our own Great Canadian Myth, that multiculturalism in Canada denotes an absence of systemic racism. Given that Canada has been built and sustained by immigrants since its inception, and given that state multiculturalism has been official government policy in Canada since 1971 (McCreary, 2009), Canadian society cannot therefore be racist.

Thobani (2007) offers several important insights into the origin of this narrative and how it came to be so prevalent in mainstream cultural narratives in Canada. To begin, she argues that in the dominant narrative of Canadian society, to be "Canadian," one must be a law-abiding, enterprising, caring, and compassionate individual who is committed to the values of diversity and multiculturalism. This narrative further suggests that contemporary Canadian identity was forged by the nation's original settlers who overcame great adversity in founding the nation and did so in the face of serious challenges from "outsiders" who threatened to destabilize or undo the 
creation of Canadian society as "we" know it. These outsiders were of a different "stock" from the original settlers, who were of Western European origin, and continue to be overrepresented on the margins of Canadian society today (Thobani, 2007, p. 4).

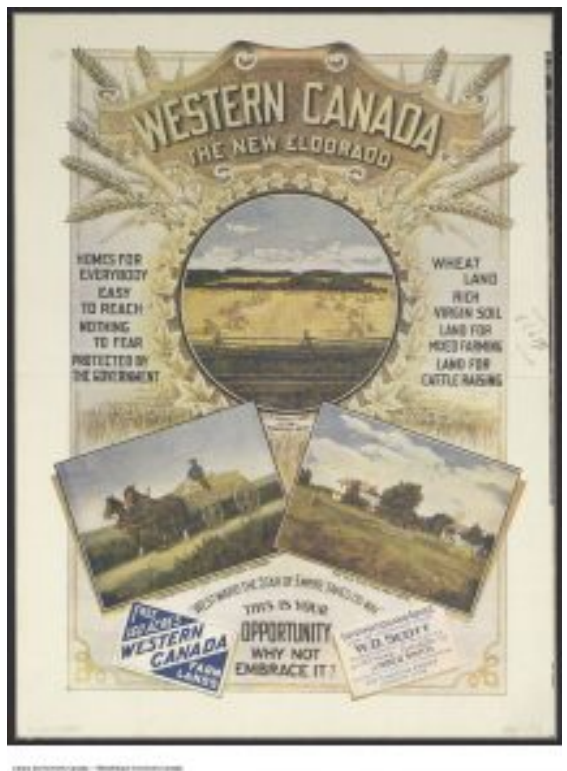

Western Canada: The New Eldorado. Poster advertising free farmland. c. 1890-1920.
European systems of governance were brought over with the original settlers, and great importance was placed on "rational" thought in the development of the national subject, or "citizen." Other ways of thinking and being, particularly those of non-Western immigrants and Indigenous peoples, were seen as either "foreign" or "threatening." These lawful, industrious, and God-fearing individuals laid the foundations for what would later become the Canadian state, and they did so in a manner that was supposedly less violent than in the United States (Thobani, 2007, p. 35).

But missing in this narrative is the construction of "which" laws were created by "whom" and for "what" purposes. The Doctrine of Discovery lies at the heart of many colonial narratives

in Canada and portrays North America as a vast wilderness "tamed" by hardy Europeans. This narrative completely erases Indigenous nations from Canadian history-history that is then taught to future generations as "fact" in state-sanctioned public education (Shanahan, 2019).

\section{Historical Anti-Immigrant Sentiment}

As a result, in their quest to become "more Canadian," immigrants and refugees have often aligned with colonial narratives for the chance to attain some benefit associated with assimilation. However, migrants who become citizens and successfully integrate into Canadian society are never able to fully shed their labels as immigrants or refugees. Regardless of how long they may have lived in Canada, a non-white person is far more likely to be asked where they are from than a white person is (Thobani, 2007, p. 155). The following examples provide a vivid illustration of the historical (and institutional) racism encountered by people of colour upon arrival in Canada. 


\section{A. Anti-Chinese Sentiment in Canada}

Unfortunately, although immigrants from China have long maintained a presence in Canadian society, Chinese immigrants have endured much discrimination in Canada. Immigrants from China played a key role in the construction of the Canadian Pacific Railway in the 1870s-a key railway that connected British Columbia with the rest of Canada. Despite only earning roughly half the wages paid to white Canadian workers-and having money deducted for food-as well as dying at a much greater rate than their nonChinese counterparts, Chinese workers were not recognized for their efforts when the railway was completed (Government of British Columbia, n.d.).

To make matters worse, in 1885 , the Canadian government passed the Chinese Immigration Act, which

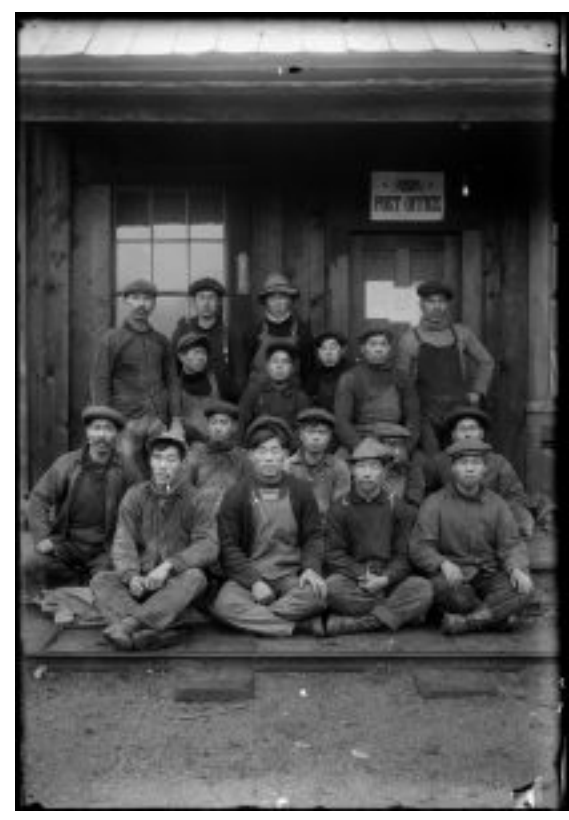

Chinese men in front of the post office. Royal City Planing Mill at the south end of Carrall St. in Vancouver, BC. c. 1900.

instituted a mandatory entry fee, or "head tax," of \$50 for every Chinese immigrant in Canada (Library and Archives Canada, 2021a). When this was not successful in stopping the flow of immigrants arriving from China, the head tax was raised to $\$ 100$ in 1900 and to $\$ 500$ (equivalent to two full years' wages) in 1903 (Chan, 2016). In 1923, restrictions on Chinese immigrants were tightened further, and immigration from China was effectively banned, though exceptions were made for small numbers of merchants, diplomats, and foreign students. This piece of legislation was not repealed until 1947 (Canada Museum of Immigration at Pier 21, 2021a).

It is important to recognize that antipathy towards Chinese immigrants in Canada did not stop with the head tax. In 1907, thousands of Canadians rallied in downtown Vancouver to protest increasing immigration from China, Japan, and other Asian countries. The rally was organized by a group calling themselves the Asiatic Exclusion League and was aimed at pressuring the government to enact policies to "keep Canada white" (Mackie, 2017). The rally quickly turned violent as participants attacked Chinese-owned businesses and homes in areas that had higher numbers of Chinese and Japanese immigrants (Laurier University, 2020). 
Finally, in 1908, the Canadian government passed the Opium Act, the first anti-drug law in the country. The Act criminalized the production, distribution, possession, and consumption of opium, and was passed in response to the federal government's perceived concerns about the negative influence of Chinese opium on young, white Canadian girls (Carstairs, 1999, p. 69).

In 2006, former prime minister Stephen Harper offered an official apology and symbolic reparations to Chinese Canadian families harmed by the head tax (Clark, 2006).

\section{B. The Komagata Maru Incident and Anti-Indian Sentiment in Canada}

In 1908, the federal government passed the Continuous Journey Regulation. An amendment to the Immigration Act of 1906, this new regulation stated that a person would not be permitted to immigrate to Canada if they did not travel to Canada directly from the country of their birth or citizenship. It was largely targeted towards people from India (and to a lesser extent, Japan) who could not physically make a journey directly to Canada by ship and were deemed to be "incompatible" with the climate and way of life in Canada (Canadian Museum of Immigration at Pier 21, 2021b).

In response to terrible economic conditions in their home communities, 376 passengers boarded the Komagata Maru in India and set sail for Canada. The ship's long voyage had them travelling from Calcutta to Hong Kong, Shanghai, and Yokohama before arriving in Vancouver (McRae, 2021c).

84 | Multiculturalism and Myth-Making in Canada 


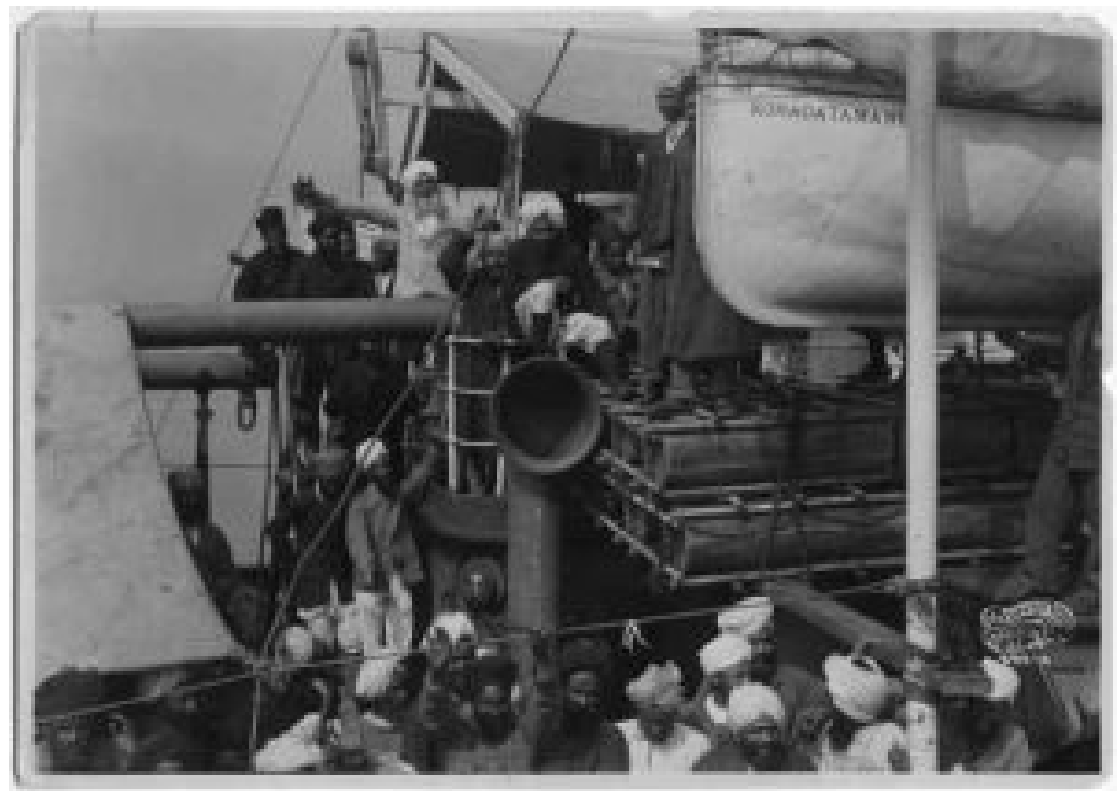

Sikh passengers aboard the ship Komagata Maru, 1914.

Unfortunately, upon arrival in Canada, the Komagata Maru was not allowed to dock, and the passengers were prohibited from leaving the ship. In essence, the ship remained a floating prison for approximately two months; no one was allowed on or off, and the people on board had restricted access to food and water (McRae, 2021c).

However, established Indo-Canadian communities organized support for the passengers, to which the federal government responded by sending in the army and police to force the ship to turn around (University of the Fraser Valley, 2021). In the end, out of the 376 passengers aboard, only 24 merchants were allowed to stay, and four months after the ship set sail, it arrived back in Calcutta. In the ensuing riot that took place in India, 16 people were shot and killed by police, and more than 200 others were arrested on suspicions of being political revolutionaries (McRae, 2021c).

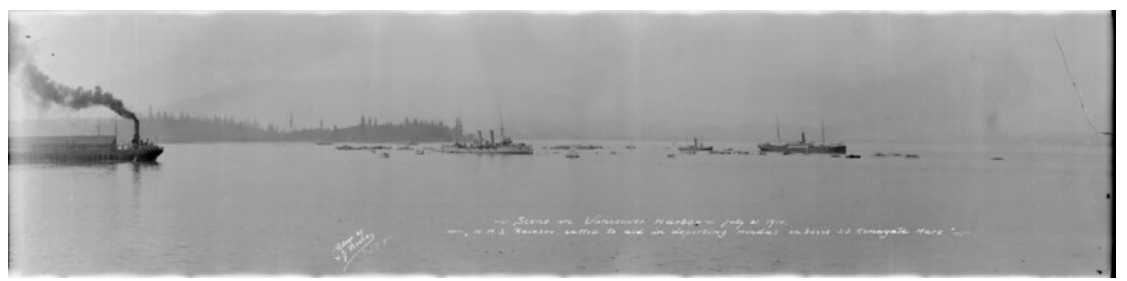

Writing on photograph reads "Scene in Vancouver Harbor - July 21, 1914 "H.M.S. Rainbow, called to aid in deporting Hindus on board S.S. Komagata Maru" 
Former prime minister Stephen Harper informally apologized for this incident in 2008, and a formal apology on behalf of the federal government was issued by Prime Minister Justin Trudeau in 2016 (CBC News, 2016).

\section{The War Measures Act and Ukrainian Internment Camps}

In 1914, the federal government passed the War Measures Act in response to Canada's entry into World War I (Smith, 2013). The Act allowed the government to suspend civil liberties in times of war or national crisis and was in effect from 1914 to 1920. Approximately 80,000 people who immigrated from the Austro-Hungarian Empire, most of whom were Ukrainian, had to register as "enemy aliens" with the federal government and were subsequently subject to routine policing, monitoring, and harassment. The government also confiscated their money and property (McIntosh, 2018).

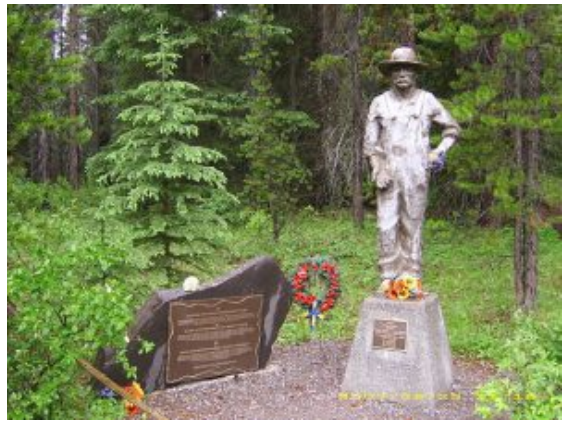

Castle Mountain Interment Camp Memorial on the Bow River Parkway, where prisoners and forced labourers were interned in World War I in what would become Banff National Park.
Between 5,000 and 10,000 Ukrainians were interned in 24 work camps scattered across Canada and were used as forced labour to create the basic infrastructure for national parks in the Canadian West. They were paid low wages, had money deducted for their lodging accommodations, and were subjected to harsh treatment from guards. One hundred and seven people died in the camps-six were shot trying to escape, and the others died from disease, injury, or by suicide (McIntosh,

2018).

In 2008, the Canadian government created a trust fund for the Ukrainians and other diaspora communities impacted by the internments to commemorate this sad chapter of Canadian history (The Canadian Press, 2008).

\section{The War Measures Act and Japanese Internment Camps}

The federal government re-enacted the War Measures Act in 1939 following Canada's entry into World War II, which remained in effect until 1949. After the bombing of Pearl Harbour in the United States by the Japanese military, Canada subsequently declared 
war on Japan, and Canadian society saw a dramatic increase in anti-Japanese hysteria, which was inflamed by the media (Marsh, 2012).

All men of Japanese origin aged 18 to 45 were arrested and dispersed to one of 10 internment camps across Canada (McRae, 2021a). All property and money they owned was confiscated and sold by the federal government to non-Japanese Canadians, 4,000 people were stripped of their Canadian citizenship and deported to Japan (Library and Archives Canada, 2021b), and 23,000 people were displaced and/or interned by the Canadian government in forced labour camps, despite the fact that $\underline{75 \%}$ of these people were either Canadian-born or naturalized residents in Canada (McRae, 2021a).

In 1988, then-prime minister Brian Mulroney publicly apologized for what happened to Japanese Canadians during World War II and announced Notice in newspaper June 19, 1942. compensation of $\$ 21,000$ for every Japanese person impacted by their forced displacement (CBC, 1988).

\section{E. Antisemitism, Jewish Refugees, and the MS St. Louis}

In 1933, the National Socialist (Nazi) Party, led by Adolf Hitler, consolidated its power and control in Germany. More than 800,000 Jews fled Nazi Germany after being stripped of all their property and threatened with violence by the paramilitary wings of the government. Canada accepted only 4,000 Jews in total between 1933 and 1939 (Kleinmann Family Foundation, n.d.), with a senior government official reportedly stating that "none is too many" when discussions of admitting Jewish refugees arose within government circles (CBC, 1982).

In addition, on May 13, 1939, 937 Jewish refugees boarded the MS St. Louis after losing their businesses and homes, hoping to settle in the Americas (Yarhi, 2015). Upon arrival in Havana, Cuba, only 29 passengers were able to leave the ship, and after two weeks, the MS St. Louis was ordered to leave. Subsequent calls for asylum to the governments of Argentina, Paraguay, Uruguay, and Panama were rebuffed, 
and pleas to the Government of the United States were not only refused, but the American government sent a warship to accompany the MS St. Louis as it sailed north (Kleinmann Family Foundation, n.d.).

Canada's response was similarly shameful. The federal government stated that this was "not a Canadian problem," with Director of Immigration Frederick Blair going so far so as to officially state that "No country, could open its doors wide enough to take in the hundreds of thousands of Jewish people who want to leave Europe: the line must be drawn somewhere" (Yarhi, 2015). Faced with no other alternative, the ship returned to Europe, and 254 of its passengers died in the Shoah (Holocaust).

In 2018, Prime Minister Justin Trudeau officially apologized for the Canadian government's decision to formally turn away Jewish refugees aboard the MS St. Louis (Abedi, 2018).

\section{F. Slavery and Anti-Black Racism}

Many people born and raised in Canada are at least somewhat familiar with the problematic history and legacy of slavery and systemic anti-Black racism in the United States, but Canada's treatment of Black Canadians is far less well known, and even less discussed.

Lands that are now part of what we call Canada participated in the transatlantic slave trade for over two centuries (McRae, 2021d). Although not as widespread as it was in the United States, slavery in the territories of British North America still referred to people as being the property of slaveowners, and it was not uncommon for enslaved people to be horribly punished for whatever the "slaveowners" felt was an infraction. This was illustrated by the flight of enslaved individuals from Canada to the State of Vermont in 1777 because Vermont had abolished slavery at a time when it was still legal in Canada (Ostroff, 2019). 

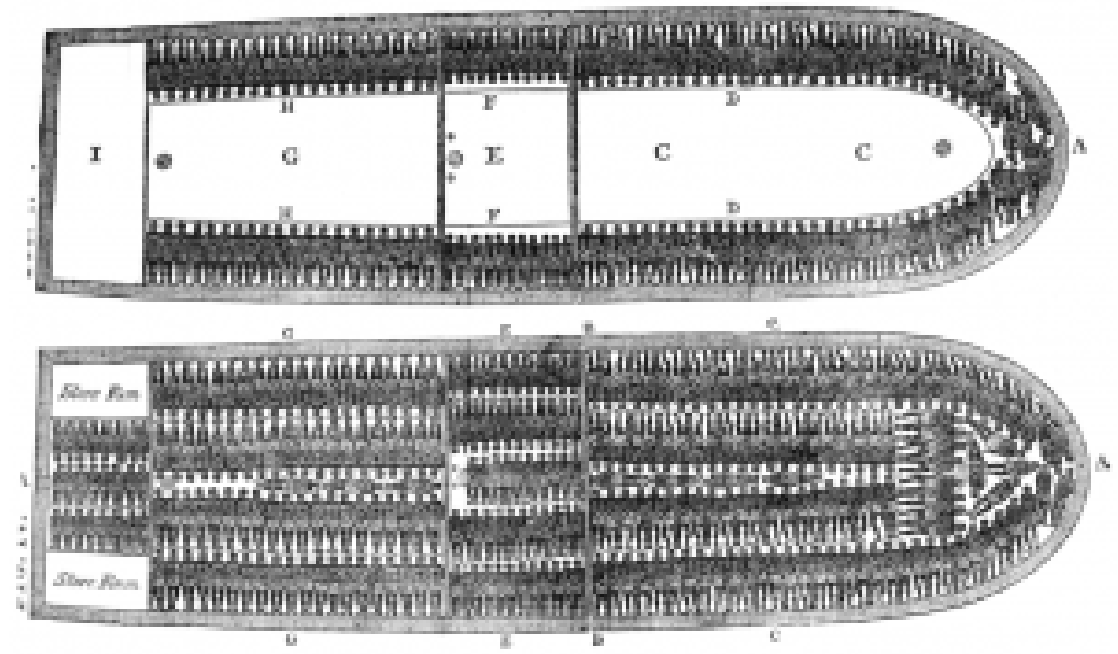

Interior layout of a slave ship from Abstract of the Evidence for the Abolition of the Slave Trade, 1791.

However, it is important to recognize that attitudes towards slavery began to change in the Canadian territories much more quickly than in the United States, and by 1834, the institution of slavery had been outlawed throughout all the territories controlled by Great Britain (Henry, 2006). This development allowed for the emergence of the Underground Railroad, which helped enslaved people fleeing captivity to escape to communities that had already abolished slavery. It is estimated that roughly 30,000 people escaped to Canada via the Underground Railroad (Klowak, 2011).

Despite the important though indirect role that Canada played in efforts to abolish slavery, it is important to note that the Government of Canada has not traditionally been receptive to welcoming large numbers of Black immigrants. More than 1,000 formerly enslaved Black people and their families moved from the State of Oklahoma to Western Canada between 1905 and 1912 (Shepard, 1983, p. 2), and their arrival coincided with the federal government passing the Immigration Act of 1910.

The Immigration Act allowed the Canadian government to deny immigration status to any individuals deemed "unsuitable to the climate or other requirements of Canada" (Canadian Museum of Immigration at Pier 21, 2021c). It was complemented by the passing of Order-in-Council P.C. 1324, which though never enacted, nevertheless prohibited the immigration of Black individuals, and the passing of a resolution by the Edmonton City Council in 1911 calling on the federal government to prevent mass migration by Black settlers (Canadian Museum of Immigration at Pier 21, 2021d). These efforts were bolstered by the sustained political agitation of several groups 
representing white Canadians hostile to Black newcomers arriving from the U.S. Midwest (Henry, 2019).

These resulting hostilities were reinforced by the federal government, which sent agents to Oklahoma to discourage prospective Black settlers from moving to Canada (Shephard, 1983, p. 8), and ads were published in American newspapers to create the impression that Black immigrants would not be industrious enough to cope with Canada's difficult soils and cold climate (Mundende, n.d.). Despite establishing a community of approximately 300 people in Amber Valley, Alberta, many Black Oklahoman settlers returned to the United States, whereas many others pursued economic opportunities in cities like Edmonton (Snowdon, 2017).

As a result, it would be fair to suggest that most Black newcomers did not find Canada to be as safe and welcoming as they had hoped. Although slavery had been abolished, Black people in Canada encountered systemic discrimination. Ontario and Nova Scotia passed legislation that created racially segregated schools for white and Black students, while Alberta, Saskatchewan, New Brunswick, and Prince Edward Island allowed schools to refuse access to Black children (Henry, 2019).

Segregated schools continued to operate in Ontario and Nova Scotia until 1965 and $\underline{1983}$, respectively, and Blacks encountered refusal of services in restaurants, theatres, and on public transportation for much of the 19th and early 20th centuries (New Youth, 2019). Attitudes towards segregation did not begin to meaningfully change throughout much of Canada until Viola Desmond challenged long-standing policies that reinforced segregation in 1946. Desmond refused to leave the designated "Whites only" section of a local theatre house and was arrested for occupying a seat she did not pay full price for (seats for Black people cost marginally less but did not offer as clear a view of performers) (Bingham, 2013).

Interestingly, Desmond's courageous activism occurred nine years before far more widely known Rosa Parks helped spark the Civil Rights Movement in the United States (Coletta, 2018). However, it was not until the early 21st century that her enormous contributions towards the fight for social justice were officially recognized. In 2010, the Government of Nova Scotia formally apologized to Viola Desmond's family (Darrow, 2010), and in 2018, the Bank of Canada featured Desmond on Canada's new \$10 bill (BBC News, 2019).

Unfortunately, though, one might not find a more explicit example of systemic antiBlack racism in Canada than the story of Africville, Nova Scotia. Located on the outskirts of Halifax, Africville was founded in the mid-1800s by the descendants of Black refugees fleeing slavery in the United States shortly after the American War of Independence and existed for almost 150 years. Although many of the Black settlers were enticed to move to Nova Scotia by the promise of land (McRae, 2021b), established white residents were hostile to the mass arrival of the Black emigrés. 
As a result, the municipal government in Halifax designated the city's North End as the most suitable location for these Black families to establish themselves (Khan, 2021). Unfortunately, the land there was the most inhospitable in the area, and to make matters worse, the residents of Africville were denied basic services such as paved roads, running water, electricity, and waste removal, despite the fact that they paid taxes like any other Halifax residents. The community's pleas for intervention from the provincial government were also ignored (Khan, 2021).

The close to 400 residents who chose to make their lives in Africville faced increasing hostilities from the municipal government; homes were expropriated to construct a railway, and an infectious disease hospital, prison, and garbage dump were placed in close proximity people's homes (McRae, 2021b). Under the guise of urban renewal and citing public sanitation concerns, the Halifax City Council voted in 1964 to begin a fiveyear process of forcibly relocating the residents of Africville and bulldozing any homes in the area. Residents were opposed to the idea and saw it as an attempt to destroy their community. The last home in Africville was razed in 1969 (McRae, 2021b).

In 1996, the federal government designated the site of Africville a National Historic Site, and in 2010, then mayor Peter Kelly formally apologized for the eviction of Black Canadian families and the razing of their homes in Africville (Barber, 2010).

国 One or more interactive elements has been excluded from this version of the text. You can view them online here: https://openeducationalberta.ca/settlement/?p=91\#oembed-1

\section{G. Colonialism, Genocide, and Anti-Indigenous Racism}

Although each of the above examples provides ample evidence to challenge the Great Canadian Myth in its own right, it is the legacy of colonialism and the genocide of Indigenous Peoples in Canada that most explicitly problematizes the denial of systemic racism in this part of the world.

\section{A: Land, Treaties, and Colonialism}

When considering the historical relationship between the Canadian government and FNMI (First Nations, Métis, and Inuit) groups, it is crucially important to recognize 
the importance of land to Indigenous Peoples and communities. Although not unique to the Indigenous nations of Turtle Island (the Indigenous name for North America), connections to the land are very closely tied to cultural identity and tradition. Land has historically provided the opportunity to grow food, obtain materials for shelter, and in many cultures, represents a connection to the spiritual world. As a result, knowledge of the land is vital to the survival of many Indigenous cultural practices. The disruption of a people's connection to their traditional territories has been highly disruptive to their cultural practices and, in turn, to their personal and communal selfidentity.

Land is central to colonialism. Stinson (2016) defines colonialism as "a policy or set of policies and practices where a political power from one territory exerts control in a different territory" (p. 1). A key factor in the process of colonization therefore involves sending people from the colonizing country to live on the newly taken-over land; these people are referred to as "settlers" (Osman, 2017). An unfortunate dark side of the history of many countries that have a rich legacy of immigration, such as Canada, Australia, and the United States, is that successive waves of immigration have been used to perpetuate colonial relationships to land, resources, and Indigenous peoples. The Indigenous populations of these territories have subsequently been replaced by waves of migrants, which has ultimately led to the creation of a society that is culturally distinct from the countries of origin of the original settlers. This subset of colonial relations is referred to as settler colonialism (Barker \& Battell Lowman, n.d.).

As a settler colonial society, it is important to recognize the importance of land in the development of what has become known as "Canada." As noted above, the Doctrine of Discovery exemplified colonial logic (Shanahan, 2019), but it is important to recognize that such "discoveries" represented little more than an acknowledgement by European colonists that a given landmass already existed (Belshaw, Nickel, \& Horton, 2016). In other words, nothing was actually discovered because people had been living in lands foreign to Europeans for millennia.

Equally important to recognize is the diversity of Indigenous Peoples in Canada and other settler colonial societies. Much like how European countries have their own distinct cultures, languages, and worldviews, so too do the Indigenous nations of Turtle Island. The Assembly of First Nations asserts that there are over 50 distinct nations and language groups across Canada, in 634 First Nation (reserve) communities (Assembly of First Nations, n.d.).

As such, central to the understanding of the legacy of colonialism in Canada is the history of treaties. In short, treaties refer to legal agreements made between governments in Canada and Indigenous Peoples (Government of Canada, 2020). Although these accords define the rights and responsibilities of all signatories, it is important to note that cultural differences in the understanding of what constituted 
a treaty relationship would lead to tragic consequences for Indigenous Peoples in Canada.

Although the first Europeans arrived in Canada in 1497, the first European settlement in Canada was not established until 1604. Archaeological evidence demonstrates that Indigenous Peoples have been living in Canada for at least 13,500 years, and as such, it became important for European colonists to establish agreements with Indigenous nations upon contact (Canadian Museum of History).

In 1613, Gusweñta, also known as the Two-Row Wampum Treaty, was signed between Haudenosaunee and Dutch leaders and represented an agreement whereby Europeans and Indigenous Peoples would share the land but live separately from one another "for as long as the grass is green, as long as the water flows downhill, and as long as the sun rises in the east and sets in the west" (Powless Jr., 1994, p. 21).

The Gusweñta greatly influenced the Royal Proclamation of 1763, a British government document outlining the guidelines for settlement in what is now known as North America. Significantly, it stated that all land in North America was to be considered Indigenous territory until it was surrendered in a treaty (University of British Columbia, 2009b). The Royal Proclamation was written without input from First Nations representatives and allowed the British "administration" of traditional Indigenous territories and the creation of the first reserves. More importantly, it forbade settlers from claiming land from Indigenous-controlled territories and the granting of land titles by colonial governments unless such land was first bought by the Crown and then sold to settlers. It further set out that only the Crown could buy land from First Nations, and thus inherently recognized Indigenous claims to their traditional territories (Slattery, 2015, p. 14).

These important recognitions led to numerous subsequent treaties (see the Upper

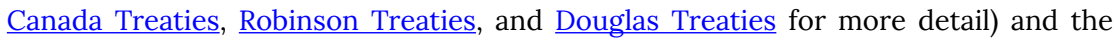
eventual signing of the numbered treaties that have come to define Indigenous-Crown relations in Western Canada. Starblanket (2008) asserts that Indigenous perspectives on treaty-making were that treaties were based on peace and friendship and allowed two parallel legal systems to co-exist on the same territory, which was to be shared. In contrast, the Crown felt that it had jurisdiction over Indigenous territories (via the Doctrine of Discovery); the Crown operated as though it had the ultimate authority over the Indigenous territories it claimed and was trying to formalize its control over these lands.

For the Crown, the treaties thus represented a surrender of title to the land and an acceptance of the legal authority of the Canadian government in exchange for certain benefits to be provided. These benefits included the creation of communities on reserve lands, the honouring of hunting and fishing rights, and the setting aside of funds for Indigenous Peoples to adopt more Western ways of living pertaining to 
agriculture and Eurocentric ways of parenting and educating children (University of British Columbia, 2009a).

The differing interpretations of what the treaties represented, particularly since the treaties were written documents that were signed between Europeans and Indigenous Peoples who had a practice of creating accords and passing on knowledge orally (Canada's First Peoples, 2007), has resulted in accusations that treaty signings constituted the theft of Indigenous territories by the Canadian government. Unfortunately, the results of treaty-making with the Canadian government have proven disastrous for Indigenous Peoples living in Canada (Facing History and Ourselves Collective, n.d.).

\section{B. Residential Schools and Other Instances of Genocide}

Between 1842and 1844, the Bagot Commission (named after Charles Bagot, the then Governor General of North America) conducted a two-year review of conditions on reserves. The Commission concluded that reserves were half-civilized states and made several recommendations for "improving" education on them (Edmond, 2014). Chief among them was the creation of federally-run Indian residential schools for the purposes of separating children from their parents and forcing Indigenous children to abandon their cultures and identities (Rheault, 2011, p. 1).

In 1847, the Assistant Superintendent General of Indian Affairs authored a report indicating that "Indians" needed to be raised to the level of whites. It was decided that the best way to accomplish this was to Christianize them and force them to adopt non-Indigenous values; the first federally-run Indian residential school subsequently opened in Ontario in 1848 (Petit, 1997, p. 15).

In 1876, the Indian Act was passed (Parrott, 2006). The Act criminalized the expression of Indigenous identity through governance or culture, barred Indigenous Peoples from practising their traditional religious ceremonies, determined who was and was not a "Status Indian" based on their paternal lineage, and led to the passage of the pass system, which prohibited travel on and off reserve by any Indigenous person unless they were authorized in advance by a government agent (Indigenous Corporate Training, 2015). The Act also authorized the federal government to take responsibility for the education of Indigenous Peoples and ensured that Indigenous children could be forced to move off the reserve and be assimilated into mainstream Canadian society.

In 1879, the Davin Report, written by journalist, lawyer, and politician Nicholas Flood Davin, called for the aggressive civilization of Indigenous Peoples, referred to "Indian culture" as being a contradiction (Facing History and Ourselves Collective, n.d.), and 
stated that the aim of education was to "kill the Indian in the child." The report became the theoretical foundation for Canada's Indian residential school system (University of British Columbia, 2009d). As a result of Davin's conclusions, in 1883, the federal government began building residential schools far away from reserve communities (Canadian Geographic, n.d.). In 1892, the government passed operational control of the schools to churches (Catholic, Anglican, Presbyterian, and Methodist), and in 1894, attendance at the schools was made mandatory for children between the ages of seven and 16; in 1908, this was changed to include children between the ages of six and 15 (Edmond, 2014). Parents who resisted were threatened with large fines, imprisonment, and/or loss of treaty benefits (Fraser, 2020).

In 1907, Dr. Peter Bryce, medical inspector for the Department of Indian Affairs, toured the residential schools of Western Canada and British Columbia and wrote a damning report on the health conditions at the schools. Labelling them "criminal," Bryce reported that Indigenous children were deliberately infected with diseases like tuberculosis and were left to die untreated as a regular practice (Hay, Blackstock, \& Kirlew, 2020).

Bryce cited an average mortality rate of $30 \%$ to $60 \%$ in the residential schools he surveyed and a practice of poor bookkeeping that made it difficult for outside investigators to accurately determine student causes of death (Annett, n.d.). Bryce was so appalled by what he witnessed that he went so far as to state that in his professional opinion, the state-sanctioned practices in residential schools were acts of genocide (Nandogikendan, n.d.). Bryce's final report was not published by the federal government (Smith, 2007).

In 1920, the Indian Act was amended to require Indigenous children over seven years of age to attend a residential school for at least 10 months every year (Parrott, 2006). Justifying this amendment, Duncan Campbell Scott, then Deputy Superintendent of Indian Affairs, was quoted as saying:

"I want to get rid of the Indian problem. I do not think as a matter of fact, that the country ought to continuously protect a class of people who are able to stand alone .... Our objective is to continue until there is not a single Indian in Canada that has not been absorbed into the body politic and there is no Indian question, and no Indian Department, that is the whole object of this Bill" (1920, p. 55, as cited in The Critical Thinking Consortium, n.d.).

In 1928, the Sexual Sterilization Act was passed in Alberta (CBC News, 2010). It allowed any inmate of a residential school to be sterilized upon the approval of the school principal. As a result, 2,834 women and girls were sterilized, with Indigenous women comprising $6 \%$ to $8 \%$ of this number (Stote, 2019). In 1931, there were 82 active residential schools in Canada (the highest number), and in 1933, residential school principals were made the legal guardians of all Indigenous students (Union of Ontario 
Indians, 2013, p. 4). Parents were forced to surrender legal custody of their children to the principal or risk imprisonment. Mandatory attendance in residential schools did not end until 1948 (Rheault, 2011, p. 2), and the last residential school closed its doors in Saskatchewan in 1996 (Miller, 2012).

More than 150,000 Indigenous children were forced to attend residential schools, and tens of thousands of survivors reported horrific experiences of physical, psychological, and sexual violence while they attended the schools; at least 3,200 student deaths have been confirmed from official records (Hopper, 2021). However, that number is widely considered to be underreported, and new evidence continues to emerge to substantiate the claim that mortality rates at residential schools were far higher than has been publicly acknowledged (Truth and Reconciliation Commission, 2015).

In response to the horrors encountered by students at residential schools, a group of survivors launched a class-action lawsuit against the Government of Canada. The suit was settled in 2006, which led to a public apology from then prime minister Stephen Harper in 2008 and the creation of the national Truth and Reconciliation Commission (TRC) (Government of Canada, 2021). The Commission operated from 2007 to 2015 and focused on formally documenting the horrors of residential schools.

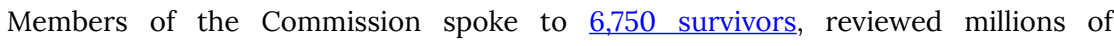
documents, and ultimately concluded that Canada engaged in a systemic campaign of cultural genocide against Indigenous Peoples (Truth and Reconciliation Commission, 2015, p. 102). In response, the TRC issued 94 Calls to Action to advance the prospect of reconciliation between Indigenous and non-Indigenous people living in Canada.

Unfortunately, these are not the only acts of genocide and colonial violence that the federal government has been forced to acknowledge and begin to address. In response to growing public pressure, in 2015, the federal government launched a national inquiry into Missing and Murdered Indigenous Women and Girls (MMIWG).

Indigenous women in Canada are three times more likely to be the victim of a violent crime than non-Indigenous women and are seven times more likely to be murdered (Amnesty International, 2014). The persistence of this phenomenon in Canadian society-and the unwillingness of successive federal governments to address it-led the commission to conclude that genocide of Indigenous women has been occurring unabated in Canada (National Inquiry into Missing and Murdered Indigenous Women and Girls, 2019, p. 26).

The federal government was also forced to recognize and apologize for the Sixties Scoop. The term "Sixties Scoop" refers to the disproportionate number of Indigenous children who were forcibly removed from their homes and communities, often over the objections of their families, in the second half of the 20th century (University of British Columbia, 2009c). These children were then placed into the homes of 
predominantly shite, middle-class Canadians, who were responsible for providing them with a "stable" upbringing. Many of the families impacted by the Sixties Scoop consisted of residential school survivors, and apprehended children encountered a loss of their cultural identity as a result of their experiences. Furthermore, the individuals responsible for the "scooping" were often social workers or other social services workers (Alston-O'Connor, 2010, p. 54). The result of this has been a strong and lingering distrust of social workers in many Indigenous communities in Canada (Thibodeau \& Peigan, 2007, p. 53).

Watch the following video to review the timeline of these events surrounding the residential school system.

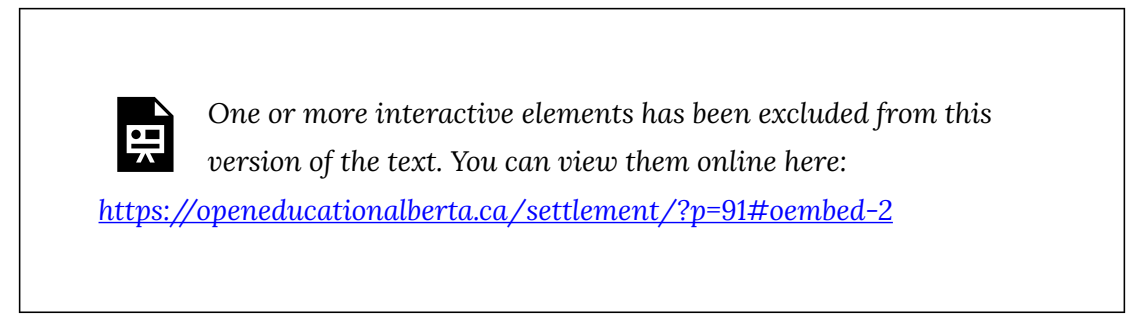

The examples outlined above are not easy to digest or discuss; however, they are very important chapters of Canadian history that problematize the Great Canadian Myth and are thus critical for settlement workers to be aware of as they enter the field. Settlement workers will support many people who are living with the legacy of systemic racism. It is important that any help offered to service users play a role in reconciliation with Indigenous Peoples and not result in the recreation of colonial narratives or practices. The remaining sections of this chapter will provide settlement workers with tools and strategies for adopting an anti-racist and anti-oppressive approach to settlement work.

\section{Learning Activity 2: Knowledge of Canadian "History" Quiz}




\section{INSTRUCTOR NOTE}

Although this activity can work well in an in-person think-pair-share format, it could also work well as an online discussion forum topic.

\section{Image Credits (images are listed in order of appearance)}

\section{Queen of Liberty by stinne24, Pixabay licence}

Library and Archives Canada. (c. 1890-1920). Western Canada - The New Eldorado [Poster]. Item ID number: 2945432. https://www.bac-lac.gc.ca/eng/ collectionsearch/Pages/record.aspx?app=fonandcol\&IdNumber=2945432

Timms, P. (190-). Chinese men in front of post office [Photograph]. Vancouver Public Library Historical Photograph Collections. VPL Accession Number: 78362. https://www.vpl.ca/historicalphotos

Canadian Photo Company. (1914). Sikhs aboard ship Komagata Maru [Photograph]. Vancouver Public Library Historical Photograph Collections. VPL Accession Number: 136. https://www.vpl.ca/historicalphotos

City of Vancouver Archives. (1914). Scene in Vancouver Harbor - July 21. 1914 "H.M.S. Rainbow, called to aid in deporting Hindus on board S.S. Komagata Maru [Photograph]. Major Matthews Collection. Reference code: AM54-S4-3: PAN N151. https://www.flickr.com/photos/vancouver-archives/5456682537/in/ photolist-9jbVBp

Plaque and statue commemorating the Castle Mountain Internment Camp in Banff National Park, Alberta by Radtke67, Public domain.

British Columbia Security Commission Japanese internment notice titled "Notice to all Japanese Persons and Persons of Japanese Racial Origin" by British Columbia Security Commission, Public domain.

Interior layout of a slave ship by House of Commons, Great Britain, CC BY-SA 4.0 International licence

This activity can be facilitated in a face-to-face setting, but would be best suited to an online modality. 


\section{Oppression, Anti-Oppression, and Social Justice}

\section{Hegemony, "Common Sense," and Canadian Exceptionalism}

The Great Canadian Myth has successfully permeated the values, attitudes, beliefs, and morals of Canadian society and has set the parameters for the common sense knowledge that forms the basis for everyday life (to such an extent that it is very difficult for many Canadians to even think of what a fundamentally different world might look like). Italian social theorist Antonio Gramsci illustrated this concept succinctly through his discussions of ideology and hegemony (Burke, 2005).

For Gramsci, "ideology" refers to the set of broadly accepted beliefs and practices that frame how people make sense of their experiences and live their lives. At its core, ideology attempts to convince people that the world is organized the way it is for the best of all reasons and that society works in the best interests of all. In other words, "common sense knowledge" is a key ingredient of ideology and serves to justify the normalization of the interests of dominant groups (Burke, 2005).

Relatedly, "hegemony" refers to a situation in which all aspects of social reality are dominated by a ruling class who are able to use existing social structures to manipulate how others think, act, and feel. Gramsci argued that the rich and powerful in a society are able to rule more successfully by consent than by force, though force will be used when needed, and this consent results in the majority of people agreeing that inequality is natural (Burke, 2005).

Hegemony is accomplished through the shaping of social values through dominant social and cultural institutions such as schools, mass media, law, churches, and popular culture. If successful, the value systems of the ruling elite thus become internalized as "common sense" and "natural" by others. Gramsci's conception can help us understand why many people in the world today seem comfortable with the existence of the abject misery of others (Mastroianni, 2002).

Gramsci's conceptions of ideology and hegemony can also help explain the enduring presence of the Great Canadian Myth and the feelings of Canadian exceptionalism that it continues to generate. In short, Canadian exceptionalism refers to the Canadian government's continued promotion of immigration, diversity, and multiculturalism in the wake of nationalist populist movements in other Western liberal democracies 
(Cooper, 2017, p. 4). Among the factors that influence the development of Canadian exceptionalism are geography (Canada has never had unplanned mass migration across its borders the way many other countries have), multiculturalism as official state policy and national identity in Canada, and a well-established settlement sector that assists newcomers with the transition to life in Canada (Cooper, 2017, p. 6).

Such sentiment is bolstered by studies indicating that large cross-sections of the population in Canada support maintaining high levels of immigration and the relatively high percentage of foreign-born residents (Bloemraad, 2012, p. 2). However, a deeper examination of Canadian attitudes towards immigration and multiculturalism and the lived experiences of racialized people living in Canada problematize just how "exceptional" Canadian society is.

For example, a study conducted by Donnelly (2017) indicated that when asked to indicate to what extent the Canadian government should accept applications to immigrate from poorer countries, the majority of participants responded with "some" or "a few," a level of support that was in line with other Western countries. Similarly, almost half of Canadians surveyed believed there was a correlation between immigration and crime, and slightly less than half of respondents indicated an opposition to ending immigration to Canada entirely (Donnelly, 2017, p. 14).

In addition, research indicates that incidents of poverty, incarceration, and negative interactions with police continue to be disproportionately experienced by racialized people living in Canada. For example, the 2016 Census indicated that $20.8 \%$ of racialized people living in Canada lived in poverty, compared to $12.2 \%$ of nonracialized Canadians (Statistics Canada, 2016). In addition, racialized workers are more likely to face unemployment or underemployment and are more likely to earn less than non-racialized people (Block, Galabuzi, \& Tranjan, 2019, p. 9). For more information, see conversations regarding the immigrant wage gap here, here, and here.

Racialized people also disproportionately experience negative interactions with police and the Canadian justice system. Police in Canada continue the racist practice of carding (or "street checking"), a process of documenting proactive encounters with individuals (Henderson, 2016). Although in theory carding has been justified as a way of protecting public safety, the reality is that Black and Indigenous Canadians are far more likely to be carded by police today than non-racialized people (Huncar, 2017). These negative interactions are further represented in statistics on incarceration. The John Howard Society estimates that Black people are overrepresented in federal prisons by more than $300 \%$ (in relation to their proportion of the general population), and that number rises to $500 \%$ for Indigenous Peoples (John Howard Society of Canada, 2017). 


\section{The "Disorienting" of Canadian Exceptionalism}

Despite the unfortunate persistence of systemic racism in Canada, feelings of Canadian exceptionalism brought about by the Great Canadian Myth continue. As a result, one of the most important contributions settlement workers can make through their work is in the understanding (and challenging) of these narratives. A process of moral and intellectual reform is therefore necessary by practitioners in the field. This is difficult intellectual labour that must be undertaken and requires a thorough understanding of colonialism and the neoliberal systems of domination that lead to human displacement and migration (Burke, 2005).

Stephen Brookfield's model for engaging in critical reflection provides a useful starting point for this process, but before proceeding, it is important to understand what is meant by the term "reflective practice." Hickson (2011) argues that reflection can mean many things in human services. It may mean a process in which a person thinks about something that happened and tries to understand why it did, or it may be a process in which someone is looking to confirm something they are already thinking about. However, reflective practice occurs on two different levels: reflection in action (the thoughts of people while they are involved in a situation) and reflection on action (thoughts that occur later on, where what is considered is not only the events that took place) (Hickson, 2011, pp. 830-831).

Brookfield (2009) expands on this concept to discuss how reflective practice can challenge a person's way of thinking, being, and knowing. Building on Mezirow's conception of the disorienting dilemma (Raiku, 2018, p. 3), Brookfield argues that instances that "disrupt" the normal functioning of a person's life, such as unexpected illness, marital breakdown, or job loss, can cause them to become more aware of (and question) previously unquestioned truths. This questioning can lead to serious consideration of perspectives that challenge "common-sense knowledge" and may ultimately result in the shifting of a person's thoughts and actions (Brookfield, 2009, p. 296).

Brookfield's conceptions are particularly useful for settlement workers because they can instigate a deeper analysis of many common-sense assumptions about effective settlement work practice. Shields, Drolet, and Valenzuela (2016) provide excellent explanations of the terms "settlement" and "settlement services." They define settlement as a "process/continuum of activities that a newcomer goes through upon arrival in a new country. It includes adjustment (getting used to the new culture, language, and environment), adaptation (learning and managing new situations with a great deal of help), and integration (actively being engaged and contributing to the new community)" (p. 5). Settlement services are defined as "programs and supports 
designed to assist immigrants to begin the settlement process and help them make the necessary adjustments for a life in their host society" (p. 5).

In Canada, settlement services are often tailored to meet the specific needs and circumstances of newcomers. These include services in areas such as language acquisition, counselling on how to access the job market, credential recognition for internationally trained professionals, housing referral, family counselling, health (including mental health) information and linkages, citizenship test supports, access to sports and recreation system navigation, and community engagement. In most cases, these services are provided by various levels of government and government-funded private and/or non-profit organizations, but over the past two decades, dramatic differences have emerged in Canada's settlement sector (Shields, Drolet, \& Valenzuela, 2016, p. 16). Much of this can be attributed to the hegemonic effect of neoliberal reforms in all corners of Canadian civil society.

In short, neoliberalism can be defined as "the agenda of economic and social transformation under the sign of the free market," and it is an ideology that is synonymous with the commodification and privatization of public sector goods, services, and institutions (Connell, 2013, p. 100). It is important to note, however, that although neoliberal attempts to dismantle the welfare state can be traced back to the 1970s in Canada, it was in the 1990s that neoliberalism emerged as the dominant paradigm in public policy circles.

At its core, this capitalist restructuring of the Canadian state aimed to transform the welfare state into a "lean" state that operated less wastefully and shifted responsibility for the social reproduction of society away from government-run social programs and towards the free market. In other words, the state facilitated the development of a new moral ethos for the responsible citizen-the self-reliant person who was responsible for leading a "lean" life and providing for themselves (Sears, 1999, p. 102).

Social services were privatized, and a new market discipline was imposed on service users and public sector workers alike. The ability to obtain desired services was thus completely dependent on a person's ability to pay and nothing more. As such, it must be acknowledged that it was the state and its policies of deregulation and privatization that created new markets for neoliberalism to colonize, and not the "invisible hand" of the free market. (Sears, 1999, p. 104).

Neoliberalism's impact on the settlement sector was profound. Although the economic compatibility between migrants and the Canadian economy has always been a driving factor of immigration policy, new categories of immigrants (such as the Business Class) were created by the government to better identify applicants who could more easily contribute to the local economy and require less support from the government upon arrival (Shields, Drolet, \& Valenzuela, 2016, p. 13).

As a result, most settlement service providers now operate under a neoliberalized 
agency-based model, where workers are expected to provide individualized and/or group-based services. Preston, George, and Silver (2013) contend that this is done at the expense of developing a broader understanding of social issues and forces settlement workers to address the symptoms instead of the causes of marginalization (pp. 645-646).

Learning Activity 3: What Are My Common-Sense Understandings of the World?

Take about 10 minutes to think about some deeply-held "commonsense" assumptions about the world today. As you think about this, ask yourself the following questions:

1. When did I develop these understandings?

2. How or from whom did I learn these?

3. How have these understandings impacted the actions and choices I have taken in life?

4. How have I responded to challenges to my "common-sense" understandings of the world?

\section{INSTRUCTOR NOTE}

This activity lends itself best to an in-person small-group breakout or think-pair-share but could also work in a synchronous online learning environment or as an individual reflection.

Learning Activity 4: Disorientation of Common-Sense Knowledge

Take about 10 minutes to recall and reflect on a disorienting 
dilemma from some point in your life and how it challenged your "common-sense understandings" of the world as it is.

1. What was disorienting about it?

2. How did you respond to it?

3. How did you and your understanding of the world move on from this dilemma?

\section{INSTRUCTOR NOTE}

This activity lends itself best to an in-person small-group breakout or think-pair-share but could also work in a synchronous online learning environment or as an individual reflection.

\section{Anti-Oppressive Practice and Further "Disorientations"}

Central to successful challenges of common-sense understanding in a neoliberalized settlement sector is a thorough understanding of oppression. Deutch (2009) defines oppression as the experience of widespread, systemic injustice (p. 7). It is embedded in the underlying assumptions of institutions and rules, and the collective consequences of following those rules. Oppression is often a consequence of unconscious assumptions and biases and the reactions of well-meaning people in ordinary interactions (Khan, 2018). It can manifest itself in the following ways: 


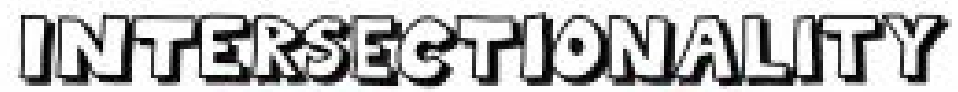

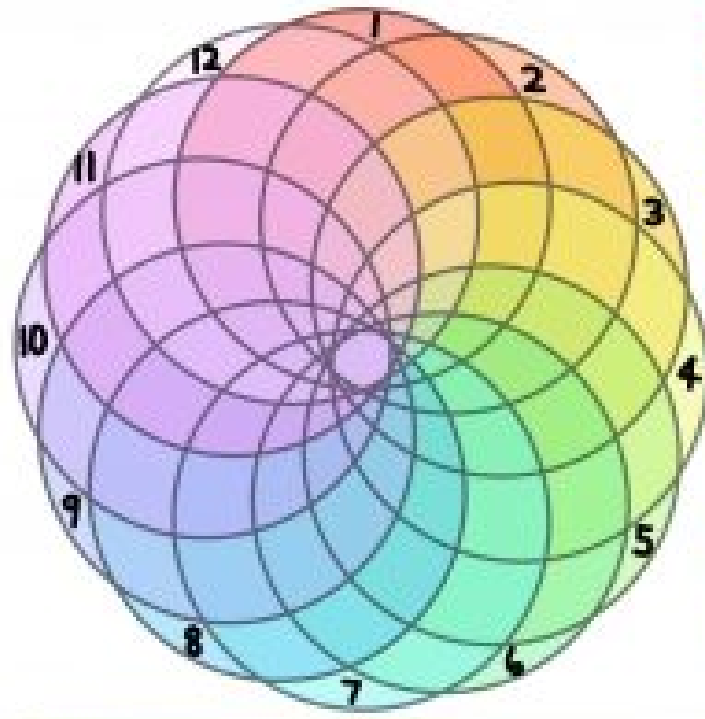

1) Race

2 Ethnicity

3 Gender identity

4 Class

5 Language

6 Religion

7 Ability

8 Sexuality

9 Mental health

10 Age

II Education

12 Body size

(... and many more..)

Intersectionality is a lens through which you can see where power comes and collides, where it locks and intersects. It is the acknowledgement that everyone has their own unique experiences of discrimination and privilege. - Kimberlé Crenshaw -

An important concept in the discussion of oppression is intersectionality. Crenshaw (1989) pioneered the term "intersectionality" to refer to instances in which individuals simultaneously experience many intersecting forms of oppression (pp. 139-140). Shannon and Rogue (2009) further elaborated on this definition to describe intersectionality as social identities in terms of race, class, gender, sexuality, nation of origin, ability, age, and so on that are not easily separated from one another. These identities intersect in complex ways as people don't exist solely as "women," "men," "white," or "working class," among others. Their identities are determined by a set of interlocked social hierarchies.

All struggles against oppression are therefore necessary components for the creation of a liberatory society (Love, 2010, p. 603). This means it is unnecessary to create a "ranking" of importance out of social struggles and suggest that some are "primary" whereas others are "secondary" or "peripheral" because of the complex ways that 
they intersect and inform one another. This method of ranking oppressions is divisive and unnecessary and undermines solidarity (the willingness of different individuals or communities to work together to achieve common goals).

Furthermore, intersectionality rejects the idea of a central or primary oppression because all oppressions overlap and simultaneously develop. In an intersectional analysis, a person's identity is layered, and the presence (or absence) of oppression is context-specific. The same person could feasibly be oppressed in one situation, and the oppressor in another (for example, a black man who is the victim of racism in the workplace but is domestically abusive). What is important is to look at the social forces that are at play and to always remember that the personal is always political (Behrent, 2014).

As a result, it would be difficult to discuss the importance of understanding oppression without understanding privilege. Garcia (2018) describes privilege as unearned social benefits or advantages that a person receives by virtue of who they are, not what they have done. Much like oppression, privilege can also be intersectional; however, because privilege is unearned, it is often invisible because those who benefit from it have been conditioned to not even be aware of its existence. Privilege is thus a very important concept because the relationship that settlement workers have with their clients is of a privileged standing. Settlement workers have the ability to deny people service and access to resources, and as a result, they have power over the lives of the service users they work with.

A thorough understanding of power, privilege, and oppression can help a settlement worker develop an anti-oppressive approach to their professional practice. In short, Clifford defines anti-oppressive practice (a concept pioneered in social work) as the following:

"Looking at the use and abuse of power not only in relation to individual or organizational behaviour, which may be overtly, covertly, or indirectly racist, classist, sexist and so on, but also in relation to broader social structures; for example, the health, educational, political and economic, media, and cultural systems, and their routine provision of services and rewards for powerful groups at local as well as national and international levels" (1995, p. 65, as cited in Burke \& Harrison, 2002, p. 132).

Being able to engage in anti-oppressive practice requires settlement workers to be able to deconstruct and challenge the Great Canadian Myth and expressions of Canadian exceptionalism, and to be able to discuss the often-complicated role played by human service professionals in the perpetuation and execution of harmful government policies towards racialized communities (Clarke, 2016, p. 119). As such, an anti-oppressive approach requires settlement workers to reflect on their work with 
service users and to interrogate the status of expert that has been given to them in their profession (Clarke, 2011).

Furthermore, conventional approaches taken by the helping professions have used deficit-based approaches to providing support to service users. As the name suggests, a deficit-based approach focuses on what a person lacks or needs, and how such needs prevent them from reaching their full potential (Hammond \& Zimmerman, 2012, p. 2). By focusing on areas of weakness, human service professionals view a person's problems as a core part of their identity. These problems mark them as different from people who do not have these problems; as a result, under a deficit-based approach, "problem solving" relies heavily on the expertise of trained professionals.

In contrast, anti-oppressive practice is a strengths-based approach in that the starting point of a conversation with a services user is what they can do, not what they cannot do or are lacking. Strengths-based approaches separate people from their problems and focus more on the circumstances that prevent a person from leading the life they want to lead (Hammond \& Zimmerman, 2012, p. 3).

An anti-oppressive approach also takes into account the process of newcomer acculturation into their host countries. Sakamoto (2007) refers to acculturation as the evolution of an immigrant's cultural belief and value systems towards an orientation that is more in line with their new communities (p. 519). Although the process of acculturation does not occur in a straight line, Sakamoto outlines four different outcomes of the acculturation process (Sakamoto, 2007, p. 519): 


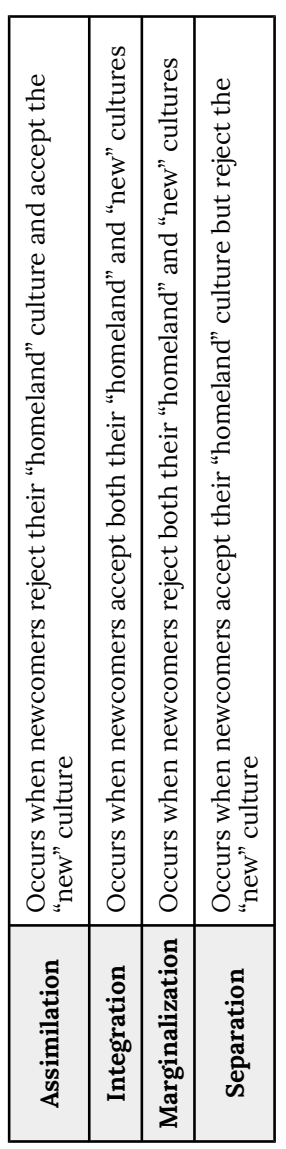


Unfortunately, the acculturation hypothesis is insufficient. When applied to a settlement work context, acculturation often takes the form assimilation, as newcomers learn how to become more "Canadianized." Such dynamics are often practised uncritically in the delivery of settlement services, and when that happens, the responsibility for successful integration completely shifts to the newcomers (Clarke, 2016, p. 215).

However, it is important to note that the successful integration of newcomers to Canada is a two-way process that requires host communities to change and adapt to the cultural differences of newcomers (Canadian Council for Refugees, 1998). In other words, integration is a dialectical relationship in which both parties benefit from an ability to adjust to changing circumstances and work together (Lusk, 2008, p. 3).

If settlement workers are to successfully employ an anti-oppressive approach, it is of vital importance that the perspectives of service users are central to any supports that are offered and that any goals that are set are achieved collaboratively with them. Such collaboration allows the worker-service user relationship to fully utilize not only the professional expertise of settlement workers, but also the expertise that service users have of the circumstances surrounding their leaves and the knowledge gained from their lived experiences (Clarke, 2016, p. 125).

As a result, a core principle of anti-oppressive practice is intersectionality, with settlement workers being required to understand the multiple identities and oppressions encountered by service users (Sakamoto, 2007, p. 528). This stands in stark contrast to efforts aimed at increasing the cultural competence of settlement workers because the journey to cultural competency is individualized and contingent on the understanding of culture through a narrower, more superficial lens (Clarke, 2016, p. 127).

A thorough understanding of how power, privilege, and oppression intersect in the lives of service users can help further destabilize "common-sense understandings" of life in Canada through the linking of personal troubles with larger public issues. When service users are viewed through the lens of partnership in the worker-service user relationship, both the user and worker can utilize their respective strengths to engage in advocacy and social actions designed to advance social justice and bring about systemic change.

Learning Activity 5: Anti-Oppressive Practice Case Studies

Develop an anti-oppressive strategy for working with each of the scenarios below. Identify what challenges your personal experiences and identities may pose and how you would overcome these challenges. 
1. Adaeze is a 22-year-old woman who was born in Canada to a mother who originally moved to Canada from Nigeria and a father who is "full status" Cree.

2. Her relationship to her parents has been strained for much of her life, and it was not uncommon for either of her parents to use physical force to "discipline" her when they saw fit to do so.

3. At age 16, she dropped out of high school and moved out of her parents' home. Although she still interacts with them from time to time, they are not central figures in her life.

4. Adaeze is fluent in English but has an incomplete understanding of the Igbo and Cree languages and cultures. She has endured discrimination from members on both sides of her family for her biracial status.

5. At age 20, she had a daughter of her own (father unknown), but she didn't feel ready to take care of the child and put it up for adoption. She has had no further contact with the baby.

6. At age 21, she lost her job as a cashier at Superstore for being late too many times, and she has been struggling to stay sober and off the streets since then.

7. She has a couple of friends to lean on for support, but when they get together, they indulge in hard partying, which she sometimes regrets.

8. She wants to get her life back on track and has come to your office for help.

Case Study B: Min-Jun

1. Min-Jun is a 43-year-old man who moved to Edmonton from South Korea three years ago.

2. He completed a master's degree in English literature from a university "back home" but decided that it would be easier for him to earn money in his field if he taught in an English-immersion environment.

3. He brought Eun-Kyung (his spouse, age 42) and children (Si-Woo, son, age 15, and Bon-Hwa, daughter, age 12) with him-they immigrated to Edmonton as a family. 
4. Min-Jun is fluent in English and is a very outgoing person. He has already made connections with Edmonton's Korean diaspora community. However, he finds the dialect of English spoken in Canada difficult to understand.

5. Despite his high level of education, Min-Jun has had a hard time finding meaningful work and has had to resort to taking several survival jobs to pay the bills.

6. Recently, he has been having conflict with other members of his family because his spouse is unhappy with their decreased social status and his children are missing their friends back home (and were never in favour of moving to Canada in the first place).

7. Min-Jun has no other family in Canada, and although he has a few new friends in Edmonton, he feels intense pressure to show outsiders that the family is "doing well."

8. He feels like his life is starting to spiral out of control and finds himself getting angrier with his family than he wants to be.

\section{INSTRUCTOR NOTE 1}

These case studies are best worked through as in-class small-group work in synchronous learning environments but can be modified to facilitate individualized learning, and groups can share their plans with their peers.

\section{INSTRUCTOR NOTE 2}

When the instructor introduces the activity, students should be prompted to identify systemic barriers encountered by service users, what "strengths" and "expertise" service users may have, and how settlement workers can work collaboratively with service users (and thus resist the urge to play the role of "expert" who is helping fill gaps in their lives).

\section{Allyship and Social Justice}

Among the most important roles that can be played by a settlement worker is that of an ally. Allyship occurs when a person with privilege attempts to work and live 
in solidarity with marginalized peoples and communities (British Columbia Teachers' Federation, 2016). Allies take responsibility for their own education on the lived realities of oppressed individuals and communities and are willing to openly acknowledge and discuss their privileges and the biases they produce (Lamont, n.d.).

Such work can often result in pointed criticisms levelled at allies from the communities they are working in solidarity with, and there is a danger that despite their good intentions, allies can replicate the same systems of marginalization that they are hoping to dismantle. This is especially true of efforts to challenge systemic racism that are lead by BIPOC (Black and Indigenous People of Colour) individuals, but as the following two activities demonstrate, struggles led by members of historically marginalized communities can result in very powerful outcomes in the pursuit of social justice.

Learning Activity 6: Anti-Oppression, Allyship, and Me

When faced with the enormity of responsibly adopting an antioppressive perspective towards newcomer supports in Canada, it can feel very overwhelming.

Write down up to three takeaways (or key ideas) that you have learned in this chapter that have pushed you towards a more antioppressive perspective.

How have these takeaways shaped your understanding of effective settlement work practice?

\section{INSTRUCTOR NOTE}

This activity would be optimal as a face-to-face "think-pair-share" activity but could be effective as a topic in an online discussion forum as well. 
Watch the following videos and take notes on key points made.

Discuss the relevance of the Idle No More (INM) movement to our understandings of social justice, anti-oppressive practice, and allyship. What are the implications for settlement workers?

One or more interactive elements has been excluded from this version of the text. You can view them online here:

https://openeducationalberta.ca/settlement/?p=98\#oembed-1

Woodward, S. (2013, January 10). Idle No More documentary - Grounded News [Video]. YouTube. https://youtu.be/IzXI7aznBtc

CBC News: The National. (2012, December 19). Idle No More [Video]. YouTube. https://youtu.be/SpBdZtwH xc

One or more interactive elements has been excluded from this version of the text. You can view them online here:

https://openeducationalberta.ca/settlement/?p=98\#oembed-2

https://youtu.be/SpBdztwh_ xe

One or more interactive elements has been excluded from this

114 | Oppression, Anti-Oppression, and Social Justice 
version of the text. You can view them online here:

https://openeducationalberta.ca/settlement/?p=98\#oembed-3

CBC News. (2017, December 10). How Idle No More sparked an uprising of Indigenous people [Video]. YouTube. https://youtu.be/TYf75dKON6k

One or more interactive elements has been excluded from this version of the text. You can view them online here:

https://openeducationalberta.ca/settlement/?p=98\#oembed-4

APTN News. (2020, January 23). The legacy of Idle No More put Infocus [Video]. YouTube. https://youtu.be/V1DFyCG86ic

NOTE: For more information on the Idle No More movement, click here and here.

\section{INSTRUCTOR NOTE}

This activity would be optimal as a face-to-face "think-pair-share" activity but could be effective as a topic in an online discussion forum as well.

\section{Learning Activity 8: Why Black Lives Matter}

Watch the following videos and take notes on key points made.

Discuss the relevance of the Black Lives Matter (BLM) movement to our understanding of social justice, anti-oppressive practice, and allyship. What are the implications for settlement workers? 
-1․ One or more interactive elements has been excluded from this version of the text. You can view them online here:

https://openeducationalberta.ca/settlement/?p=98\#oembed-5

Channel 4 News. (2020, June 15). Black Lives Matter explained: The history of a movement [Video]. YouTube. https://youtu.be/YG8GjlLbbvs

One or more interactive elements has been excluded from this version of the text. You can view them online here:

https://openeducationalberta.ca/settlement/?p=98\#oembed-6

TEDx Talks. (2018, April 25). \#BlackLivesMatter | Kennedy Cook | TEDxYouth@Dayton [Video]. YouTube. https://youtu.be/Sd-VUOgS3rE

NOTE: For more information on the Black Lives Matter movement, click here, here, and here.

\section{Image Credit}

[Intersectionality Venn diagram] by sylviaduckworth, CC BY-NC-ND 2.0 Generic licence 


\section{Conclusion}

This chapter has explored what is meant by the term social justice and its relevance to effective settlement work practice. Contrary to many "common sense" understandings of how to best support newcomers in their transition to life in Canada, it is important to recognize that successful integration is a two-way process that requires earnest efforts from both newcomers and host societies (Canadian Council for Refugees, 1998).

Central to this process is a thorough understanding of the Great Canadian Myth and its impact on discussions regarding what it means to be Canadian. The perception that Canada, as a nation of immigrants, cannot play host to systemic racism overlooks the legacy of colonialism in Canada and minimizes the systemic racism experienced by racialized immigrants throughout much of Canadian history.

The Great Canadian Myth is a powerful incubator of common-sense knowledge about life in Canada, and when challenged, the result can be quite disorienting. However, becoming more aware of the intersections of oppression, power, and privilege can help settlement workers abandon deficit-based approaches to providing support in favour of adopting anti-oppressive practices.

Anti-oppressive practices provide excellent opportunities for settlement workers to act as allies and in concert with service users (Clarke, 2011). Such partnerships result in more effective advocacy on behalf of service users and the coordination of actions that can bring about the systemic changes needed to eliminate unnecessary hardships encountered by newcomers to Canada.

Learning Activity 9: Revisiting "Canadian" Values?

On your own, take a few minutes to revisit your response to Learning Activity 1 (the Canadian values you identified).

- Have these values been challenged and/or disoriented?

- If yes, why? If not, why not?

- How might the conversations sparked by this chapter cause you to re-evaluate what it means to be Canadian? 


\section{INSTRUCTOR NOTE}

This activity would be optimal as a face-to-face "think-pair-share" activity but could be effective as a topic in an online discussion forum as well.

\section{Learning Activity ro: End of Chapter Quiz}

\section{INSTRUCTOR NOTE}

This activity would be optimal as a face-to-face "think-pair-share" activity but could be effective as a topic in an online discussion forum as well. 


\section{Chapter References and Attributions}

\section{References}

Abedi, M. (2018, November 7). Canada apologizes for turning away Jewish refugees in 1939 - why that matters. Global News. https://globalnews.ca/news/4630464/ canada-justin-trudeau-jewish-refugees-apology/

Alberta Regional Professional Development Consortia. (2016). First Nations, Métis, and Inuit professional learning guide. http://www.fnmiprofessionallearning.ca/wpcontent/uploads/2017/10/FMNI_Learning-Guide_Oct2017.pdf

Alston-O'Connor, E. (2010). The Sixties Scoop: Implications for social workers and social work education. Critical Social Work, 11(1), 53-61.

Alvarado, L. A. (2010). Dispelling the meritocracy myth: Lessons for higher education and student affairs educators. The Vermont Connection, 31, 10-20. https://scholarworks.uvm.edu/cgi/viewcontent.cgi? article $=1087 \&$ context $=$ tvc

Amnesty International. (2019). Carding and anti-Black racism in Canada. https://www.amnesty.ca/blog/carding-and-anti-black-racism-canada

Amnesty International. (2014). Violence against Indigenous women and girls of Canada: A summary of Amnesty International's concerns and calls to action. https://www.amnesty.ca/sites/amnesty/files/ iwfa submission amnesty international february 2014 - final.pdf

Annett, K. (n.d.). Evidence of genocidal mortality rates in residential schools - Index. Hidden from History: The Canadian Holocaust. http://canadiangenocide.nativeweb.org/mort_rate_index.html

Arias, E., \& Xu, J. (2020). United States life tables, 2018. National Vital Statistics Reports, 69(12), 1-45. https://www.cdc.gov/nchs/data/nvsr/nvsr69/nvsr69-12-508.pdf

Asmelash, L. (2020, July 26). How Black Lives Matter went from a hashtag to a global rallying cry. CNN Online. https://www.cnn.com/2020/07/26/us/black-livesmatter-explainer-trnd/index.html

Assembly of First Nations. (n.d.). About AFN. https://www.afn.ca/about-afn/

Barber, M. (2017, December 6). Africville apology is a start, not an end. HuffPost Canada. https://www.huffpost.com/entry/africville-apology-is-a-s_b_480361 
Barker, A., \& Battell Lowman, E. (n.d.). Settler colonialism. Global Social Theory. https://globalsocialtheory.org/concepts/settler-colonialism/

Behrent, M. (2014). The personal and the political: Literature and feminism. International Socialist Review, 92. https://isreview.org/issue/92/personal-andpolitical

Belshaw, J., Nickel, S., \& Horton, C. (2016). Histories of Indigenous peoples and Canada. Thompson University Press. https://histindigenouspeoples.pressbooks.tru.ca/ chapter/3-since-time-immemorial/

Bergland, C. (2017, August 3). Sizeism is harming too many of us: Fat shaming must stop. Psychology Today. https://www.psychologytoday.com/ca/blog/the-athletesway/201708/sizeism-is-harming-too-many-us-fat-shaming-must-stop

Bingham, R. (2021, April 16). Viola Desmond. The Canadian Encyclopedia. https://www.thecanadianencyclopedia.ca/en/article/viola-desmond

The BIPOC Project. (n.d.). Our theory of change. https://www.thebipocproject.org/ our-approach

Black Lives Matter. (n.d.). About. https://blacklivesmatter.com/about/

Block, S., Galabuzi, G.-E., \& Tranjan, R. (2019). Canada's colour-coded income inequality. Canadian Centre for Policy Alternatives. https://www.policyalternatives.ca/sites/ default/files/uploads/publications/National\%20Office/2019/12/ Canada\%27s\%20Colour\%20Coded\%20Income\%20Inequality.pdf

Bloemraad, I. (2012). Understanding "Canadian exceptionalism" in immigration and pluralism policy. Transatlantic Council on Migration. https://www.migrationpolicy.org/pubs/CanadianExceptionalism.pdf

BBC News. (2019, April 30). Canada's Viola Desmond note wins international banknote competition. https://www.bbc.com/news/world-us-canada-48071926

British Columbia Teachers' Federation (BCTF). (2016). A guide to allyship. BCTF Summer Session. $\quad$ https://bctf.ca/uploadedFiles/Public/SocialJustice/EquityInclusion/ Allyship\%20handout.pdf

Brookfield, S. (2009). The concept of critical reflection: promises and contradictions. European Journal of Social Work, 12(3), 293-304. https://doi.org/10.1080/ $\underline{13691450902945215}$

Burke, B. (2005). Antonio Gramsci, schooling and education. Encyclopedia of Pedagogy and Informal Education. https://infed.org/antonio-gramsci-schooling-andeducation/ 
Burke, B., \& Harrison, P. (2002). Anti-oppressive practice: Introduction. In R. Admans, L. Dominelle, \& M. Payne (Eds.), Anti-oppressive practice (pp. 227-236). Palgrave MacMillan.

Canada's First Peoples. (2007). Treaties \& cultural change: What are the treaties? Two different views. http://firstpeoplesofcanada.com/fp treaties/ fp_treaties_two_views.html

Canadian Breast Cancer Network ( $\mathrm{CBCN})$. (n.d.). What is advocacy? https://www.cbcn.ca/en/what-is-advocacy

Canadian Broadcasting Corporation (CBC). (2018, June 25). Government apologizes for residential schools in 2008. CBC Archives. https://www.cbc.ca/archives/ government-apologizes-for-residential-schools-in-2008-1.4666041

Canadian Broadcasting Corporation (CBC). (2016, May 18). Justin Trudeau apologizes in House for 1914 Komagata Maru incident. CBC News. https://www.cbc.ca/news/ politics/komagata-maru-live-apology-1.3587827

Canadian Broadcasting Corporation (CBC). (2010, October 23). Alberta's sex sterilizations re-examined. $\mathrm{CBC}$ News. https://www.cbc.ca/news/canada/ edmonton/alberta-s-sex-sterilizations-re-examined-1.871749

Canadian Broadcasting Corporation (CBC). (2008, August 23). Harper apologizes in B.C. for 1914 Komagata Maru incident. CBC News. https://www.cbc.ca/news/canada/ british-columbia/harper-apologizes-in-b-c-for-1914-komagata-maruincident-1.747120

Canadian Broadcasting Corporation (CBC). (1988, September 22). 1988: Government apologizes to Japanese Canadians. CBC News Digital Archives. https://www.cbc.ca/ archives/entry/1988-government-apologizes-to-japanese-canadians

Canadian Broadcasting Corporation (CBC). (1982, October 6). Jews not welcome in wartime Canada. CBC News Digital Archives. https://www.cbc.ca/archives/entry/ auschwitz-jews-not-welcome-in-wartime-canada

Canadian Council for Refugees. (1998). 3. Settlement and integration. Best Settlement Practices: Settlement Services for Refugees and Immigrants in Canada. https://ccrweb.ca/sites/ccrweb.ca/files/static-files/ bpfina1.htm\#3.\%20SETTLEMENT\%20AND\%20INTEGRATION

The Canadian Encyclopedia. (2020). Upper Canada land surrenders. https://www.thecanadianencyclopedia.ca/en/article/upper-canada-landsurrenders

Canadian Geographic. (n.d.). History of residential schools. Indigenous Peoples Atlas 
of Canada. https://indigenouspeoplesatlasofcanada.ca/article/history-ofresidential-schools/

Canadian Museum of History. (n.d.). Archaeological evidence. https://www.historymuseum.ca/history-hall/archaeological-evidence/

Canadian Museum of Immigration at Pier 21. (2021a). Chinese Immigration Act, 1923. https://pier21.ca/research/immigration-history/chinese-immigration-act-1923

Canadian Museum of Immigration at Pier 21. (2021b). Continuous journey regulation, 1908. https://pier21.ca/research/immigration-history/continuous-journey$\underline{\text { regulation }-1908}$

Canadian Museum of Immigration at Pier 21. (2021c). Immigration Act, 1906. https://pier21.ca/research/immigration-history/immigration-act-1906

Canadian Museum of Immigration at Pier 21. (2021d). Immigration Act, 1910. https://pier21.ca/research/immigration-history/immigration-act-1910

The Canadian Press. (2008, May 10). Ukrainian-Canadians hail resolution of internment issue. CTV News. https://www.ctvnews.ca/ukrainian-cdns-hailresolution-of-internment-issue-1.294930

Carstairs, C. (1999). Deporting "Ah Sin" to save the white race: Moral panic, racialization, and the extension of Canadian drug laws in the 1920s. Canadian Bulletin of Medical History, 16(1), 65-88. https://utpjournals.press/doi/10.3138/ cbmh.16.1.65

Caven, F. (2013). Being Idle No More: The women behind the movement. Cultural Survival Quarterly Magazine. https://www.culturalsurvival.org/publications/ cultural-survival-quarterly/being-idle-no-more-women-behind-movement

Chan, A. (2016, September 8). Chinese Head Tax in Canada. The Canadian Encyclopedia. https://www.thecanadianencyclopedia.ca/en/article/chinesehead-tax-in-canada

City News. (2020, July 1). Anti-Black racist history in Canada: 1911 order sought to stop Blacks from immigrating. https://toronto.citynews.ca/2020/07/01/anti-blackracism-canada-immigration/

Clark, C. (2006, June 23). PM offers apology, 'symbolic payments' for Chinese head tax. The Globe and Mail. https://www.theglobeandmail.com/news/national/pmoffers-apology-symbolic-payments-for-chinese-head-tax/article711245/

Clarke, J. (2016). Doing anti-oppressive settlement work in Canada: A critical framework for practice. In S. Pashang (Ed.), Unsettled settlers: Barriers to integration (3rd ed., pp. 115-137). de Sitter Publications.

122 | Chapter References and Attributions 
Clarke, J., \& Wan, E. (2011). Transforming settlement work: From a traditional to a critical anti-oppression approach with newcomer youth in secondary schools. Critical Social Work, 12(1).

Class Action. (2021). What is classism. https://classism.org/about-class/what-isclassism/

Coletta, A. (2018, November 21). Viola Desmond, black woman who spurred end of segregation in Nova Scotia, now appears on Canada's \$10 bill. The Washington Post. https://www.washingtonpost.com/world/2018/11/21/viola-desmond-blackwoman-who-spurred-end-segregation-nova-scotia-now-appears-canadas-bill/

Collier, J. (2018). Exploring internalized classism using the regressive model of selfstigma [Unpublished dissertation]. Department of Psychology, University of Missouri-St. Louis.

Colour of Poverty. (2019). Fact Sheet \#2: An introduction to racialized poverty. https://colourofpoverty.ca/wp-content/uploads/2019/03/cop-coc-factsheet-2-an-introduction-to-racialized-poverty-3.pdf

Compton, I. (2018, October 2). The coerced sterilization of Indigenous women in Canada. The Link. https://thelinknewspaper.ca/article/the-coerced-sterilization-ofindigenous-women-in-canada

The Conference Board of Canada. (2021). Immigrant wage gap. https://www.conferenceboard.ca/hcp/provincial/society/immigrant-gap.aspx

Connell, R. (2013). The neoliberal cascade and education: an essay on the market agenda and its consequences. Critical Studies in Education, 54(2), 99-112. https://doi.org/10.1080/17508487.2013.776990

Cooper, C. (2017, February 9). Canadian exceptionalism: Are we good or are we lucky? [Final report]. 2017 Annual Conference of the McGill Institute for the Study of Canada, Montréal, Québec. https://www.mcgill.ca/misc/files/misc/ misc canadian exceptionalism 2017 final report -04-18-2017.pdf

Council of Europe. (2020). Sexism: See it. Name it. Stop it. Human Rights Channel. https://www.coe.int/en/web/human-rights-channel/stop-sexism

Critical Thinking Consortium. (n.d.). \#10 The Indian problem. https://tc2.ca/ sourcedocs/uploads/images/ HD\%20Sources\%20(text\%20thumbs)/Aboriginal\%20History/ Residential\%20Schools/Residential-Schools\%2010.pdf

Department of Sociology. (2010). Power and authority. University of Minnesota 
Libraries Publishing. https://open.lib.umn.edu/sociology/chapter/14-1-powerand-authority/

Deutsch, M. (2011). A framework for thinking about oppression and its change. Social Justice Research, 19(1), 193-226.

Donnelly, M. J. (2017, February 9). A survey of Canadian attitudes in comparative perspective [Conference presentation]. 2017 Annual Conference of the McGill Institute for the Study of Canada, Montréal, Québec. https://www.mcgill.ca/misc/ files/misc/misc surveyreport $0 . p d f$

Darrow, P. (2010, April 15). In rare posthumous pardon, Nova Scotia apologizes for black woman's 1946 arrest. The Globe and Mail. https://www.theglobeandmail.com/ news/national/in-rare-posthumous-pardon-nova-scotia-apologizes-for-blackwomans-1946-arrest/article4315080/

Edmond, J. (2014, July 7). Indian residential schools: A chronology. LawNow. https://www.lawnow.org/indian-residential-schoolschronology/\#: :text=1844\%20\%E2\%80\%93\%20Bagot\%20Commission\%20finds\%2 Oreserve,Proclamation\%20of\%201763\%20policy\%20that

Eisenmenger, A. (2019, December 12). Ableism 101: What it is, what it looks like, and what we can do to fix it. Access Living. https://www.accessliving.org/newsroom/blog/ $\underline{\text { ableism-101/ }}$

Eneas, B. (2021, June 24). Sask. First Nation announces discovery of 751 unmarked graves near former residential school. CBC News. https://www.cbc.ca/news/ canada/saskatchewan/cowessess-marieval-indian-residential-schoolnews-1.6078375

Esses, V., Sutter, A., Ortiz, A., Luo, N., Cui, J., \& Deacon, L. (2018). Retaining international students in Canada post-graduation: Understanding the motivations and drivers of the decision to stay. Canadian Bureau for International Education. https://cbie.ca/ wp-content/uploads/2018/06/Intl-students-post-graduation-RiB-8-EN-1.pdf

Facing History and Ourselves Collective. (n.d.). Stolen lives: The Indigenous peoples of Canada and the Indian residential schools. Facing History and Ourselves Publications.

Fem North Net. (n.d.). Fact Sheet \#3: Colonialism and its impacts. Canadian Research Institute for the Advancement of Women and Social Sciences and Humanities Research Council of Canada. https://www.criaw-icref.ca/wp-content/uploads/ 2021/04/Local-Women-Matter-3-Colonialism-and-its-impacts.pdf

Fraser, C. G. (2020, May 6). Resistance and residential schools. The Canadian 
Encyclopedia. https://www.thecanadianencyclopedia.ca/en/article/resistanceand-residential-schools

Garcia, J. D. (2018). Privilege (Social inequality). Salem Press Encyclopedia. https://guides.rider.edu/privilege

Geer, D. (2018, November 11). Racialized is the new Black, and Brown and ... . Open Shelf. https://open-shelf.ca/181105-racialized-is-the-new-black-and-brown/

George, P., Siver, S., \& Preston, S. (2013). Reimagining field education in social work: The promise unveiled. Advances in Social Work, 14(2), 642-657.

Government of British Columbia. (n.d.). Building the railway. https://www2.gov.bc.ca/ gov/content/governments/multiculturalism-anti-racism/chinese-legacy-bc/ history/building-the-railway

Government of Canada. (2021). Indian Residential Schools Settlement Agreement. https://www.rcaanc-cirnac.gc.ca/eng/1100100015576/1571581687074

Government of Canada. (2020). Treaties and agreements. https://www.rcaanccirnac.gc.ca/eng/1100100028574/1529354437231

Government of Canada. (2019). Settlement program: Terms and conditions. https://www.canada.ca/en/immigration-refugees-citizenship/corporate/ transparency/program-terms-conditions/settlement.html

Government of Canada. (2015). Discover Canada - Canada's history. https://www.canada.ca/en/immigration-refugees-citizenship/corporate/ publications-manuals/discover-canada/read-online/canadas-history.html

Government of Canada, Justice Laws Website. (2014). Canadian Multiculturalism Act (R.S.C., 1985, c. 24 (4th Supp.)). https://laws-lois.justice.gc.ca/eng/acts/c-18.7/ page-1.html

The Hamilton Spectator. (2017, February 16). Time to end the myth of Canadian exceptionalism. https://www.thespec.com/opinion/contributors/2017/02/16/ time-to-end-the-myth-of-canadian-exceptionalism.html

Hammond, W., \& Zimmerman, R. (2012). A strengths-based perspective. Resiliency Initiatives.

https://shed-the-light.webs.com/documents/ RSL STRENGTH BASED PERSPECTIVE.pdf

Harris, C. (2021). Crown. The Canadian Encyclopedia. https://www.thecanadianencyclopedia.ca/en/article/crown

Haudenosaunee Confederacy. (2021). Welcome to the HCCC. https://www.haudenosauneeconfederacy.com/ 
Hay, T., Blackstock, C., \& Kirlew, M. (2020). Dr. Peter Bryce (1853-1932): Whistleblower on residential schools. Canadian Medical Association Journal, 192(9), E223-224.

Henry, N. L. (2019). Racial segregation of Black people in Canada. The Canadian Encyclopedia. $\quad$ https://www.thecanadianencyclopedia.ca/en/article/racialsegregation-of-black-people-in-canada

Henry, N. L. (2020). Underground Railroad. The Canadian Encyclopedia. https://www.thecanadianencyclopedia.ca/en/article/undergroundrailroad\#: :text=The\%20Underground\%20Railroad\%20was\%20a,Northern\%20stat es\%20or\%20to\%20Canada.\&text=It\%20brought\%20between\%2030\%2C000\%20an d,North\%20America\%20(now\%20Canada)

Hickson, H. (2011). Critical reflection: Reflecting on learning to be reflective. Reflective Practice, 12(6), 829-839. https://doi.org/10.1080/14623943.2011.616687

HistoryOnTheNet. (2019). American War of Independence: Facts and summary. https://www.historyonthenet.com/american-war-of-independence-facts

Hopper, T. (2021, May 29). Why so many children died at Indian Residential Schools. National Post. https://nationalpost.com/news/canada/newly-discovered-b-cgraves-a-grim-reminder-of-the-heartbreaking-death-toll-of-residential-schools

Huncar, A. (2017, June 27). Indigenous women nearly 10 times more likely to be street checked by Edmonton police, new data shows. CBC News. https://www.cbc.ca/ news/canada/edmonton/street-checks-edmonton-police-aboriginal-blackcarding-1.4178843

Idle No More. (2020). An Indigenous-led social movement. https://idlenomore.ca/ about-the-movement/

Illing, S. (2020, March 7). What we get wrong about misogyny. Vox. https://www.vox.com/identities/2017/12/5/16705284/elizabeth-warrenloss-2020-sexism-misogyny-kate-manne

Immigration, Refugees and Citizenship Canada. (2020). 2020 annual report to Parliament on immigration. https://www.canada.ca/content/dam/ircc/ migration/ircc/english/pdf/pub/annual-report-2020-en.pdf

Imoh, C. (2020, September 30). How the failure of multiculturalism led to the rise of Black Lives Matter. The Conversation. https://theconversation.com/how-thefailure-of-multiculturalism-led-to-the-rise-of-black-lives-matter-144463

Indigenous Corporate Training. (2018). What reconciliation is and what it is not. https://www.ictinc.ca/blog/what-reconciliation-is-and-what-it-is-not 
Indigenous Corporate Training. (2015). Indian Act and the pass system. https://www.ictinc.ca/blog/indian-act-and-the-pass-system

International Forum for Social Development, United Nations. (2006). Social justice in an open world: The role of the United Nations. https://www.un.org/esa/socdev/ documents/ifsd/SocialJustice.pdf

John Howard Society of Canada. (2017, October 19). Race, crime and justice in Canada. https://johnhoward.ca/blog/race-crime-justice-canada/

Kaiser Family Foundation. (2021). 2019 poverty rate by race/ethnicity. https://www.kff.org/other/state-indicator/poverty-rate-byraceethnicity/?currentTimeframe=0\&sortModel=\%7B\%22colId\%22:\%22Location\%2 2,\%22sort\%22:\%22asc\%22\%7D

Khan, A. (2021, February 17). Africville: A story of environmental racism. Network in Canadian History \& Environment (NICHE). https://niche-canada.org/2021/02/17/ africville-a-story-of-environmental-racism/

Khan, C. (2018). Social location, positionality \& unconscious bias [PowerPoint presentation]. University of Alberta Graduate Teaching and Learning Program. https://www.ualberta.ca/graduate-studies/media-library/professionaldevelopment/gtl-program/gtl-week-august-2018/2018-08-28-social-locationand-unconscious-bias-in-the-classroom.pdf

Kleinmann Family Foundation. (n.d.). "None is Too Many": 1939 Canada - European Community - Holocaust. Eleventh Annual Cégep Holocaust Symposium. https://www.vaniercollege.qc.ca/events/holocaust04/st louis.html

Klowak, S. (2011, April 19). History spotlight: The Underground Railroad. Canada's History. https://www.canadashistory.ca/explore/politics-law/history-spotlightthe-underground-railroad

Krenshaw, K. (1989). Demarginalizing the intersection of race and sex: A Black feminist critique of antidiscrimination doctrine, feminist theory and antiracist politics. University of Chicago Legal Forum, 1, 139-167. https://chicagounbound.uchicago.edu/cgi/ viewcontent.cgi?article $=1052 \&$ context $=$ uclf

Lamont, A. (n.d.). Guide to allyship. amélie.studio. https://guidetoallyship.com/

Laurier University. (2020, November 24). Vancouver anti-Asian riots of 1907 and the parallels to Canada's modern-day racial divide. Laurier News Hub. https://www.wlu.ca/news/spotlights/2020/nov/vancouver-anti-asian-riotsof-1907-and-the-parallels-to-canadas-modern-day-racial-divide.html 
Library and Archives Canada. (2021a). Chinese - Research at Library and Archives Canada. https://www.bac-lac.gc.ca/eng/discover/immigration/history-ethniccultural/Pages/chinese.aspx

Library and Archives Canada. (2021b). Japanese Canadians: From immigration to deportation. $\quad$ https://www.bac-lac.gc.ca/eng/discover/immigration/historyethnic-cultural/Pages/japanese-immigration.aspx

Love, B. J. (2010). Developing a liberatory consciousness. In M. Adams, W. Blumenfeld, H. W. Hackman, M. L. Peters, \& X. Zuniga (Eds.), Readings for diversity and social justice (2nd ed., pp. 601-605). Routledge.

Lusk, H. M. (2008). A study of dialectical theory and its relation to interpersonal relationships [Unpublished thesis]. Chancellor's Honors Program Projects, University of Tennessee.

Mackie, J. (2017, August 21). This Week in History: 1907 The Asiatic Exclusion League is formed. Vancouver Sun. https://vancouversun.com/news/local-news/this-weekin-history-1907-the-asiatic-exclusion-league-is-formed

Marsh, J. H. (2020). Japanese Canadian internment: Prisoners in their own country. The Canadian Encyclopedia. https://www.thecanadianencyclopedia.ca/en/article/ japanese-internment-banished-and-beyond-tears-feature

Mas, S. (2015, December 14). Truth and Reconciliation final report: By the numbers. CBC News. https://www.cbc.ca/news/politics/truth-and-reconciliation-finalreport-by-the-numbers-1.3362156

Mastroianni, D. (2002). Hegemony in Gramsci. Emory University. https://scholarblogs.emory.edu/postcolonialstudies/2014/06/20/hegemony-ingramsci/

McCreary, T. (2009, September 1). The myth of the multicultural patchwork. Briarpatch Magazine. https://briarpatchmagazine.com/articles/view/the-myth-of-themulticultural-patchwork

McIntosh, A. (2018). Ukrainian internment in Canada. The Canadian Encyclopedia. https://www.thecanadianencyclopedia.ca/en/article/ukrainian-internment-incanada

McRae, M. (2021a). Japanese Canadian internment and the struggle for redress. Canadian Museum for Human Rights. https://humanrights.ca/story/japanesecanadian-internment-and-the-struggle-for-redress

McRae, M. (2021b). The story of Africville. Canadian Museum for Human Rights. https://humanrights.ca/story/the-story-of-africville 
McRae, M. (2021c). The story of slavery in Canadian history. Canadian Museum for Human Rights. https://humanrights.ca/story/the-story-of-slavery-in-canadianhistory

McRae, M. (2021d). The story of the Komagata Maru. Canadian Museum for Human Rights. https://humanrights.ca/story/the-story-of-the-komagata-maru

Millar, N. (2017, June 30). Canada's myth of multiculturalism. The Coast. https://www.thecoast.ca/halifax/canadas-myth-of-multiculturalism/ Content?oid $=8132343$

Miller, J. R. (2021). Residential schools in Canada. The Canadian Encyclopedia. https://www.thecanadianencyclopedia.ca/en/article/residential-schools

Mundende, D. C. (n.d.). African American exodus to Canada. Oklahoma Historical Society. https://www.okhistory.org/publications/enc/entry.php?entry=AF001

Nadeau, S. (2013). The immigrant wage gap in Canada: Differences between the public and private sector [Unpublished working paper]. Department of Economics, University of Ottawa. https://socialsciences.uottawa.ca/economics/sites/ socialsciences.uottawa.ca.economics/files/1303e.pdf

Nandogikendan. (n.d.). Genocide. https://nandogikendan.com/genocide-2/

National Inquiry into Missing and Murdered Indigenous Women and Girls. (2019). A legal analysis of genocide. https://www.mmiwg-ffada.ca/wp-content/uploads/ 2019/06/Supplementary-Report_Genocide.pdf

Nellis, A. (2016, June 14). The color of justice: Racial and ethnic disparity in state prisons. The Sentencing Project. https://www.sentencingproject.org/publications/ color-of-justice-racial-and-ethnic-disparity-in-state-prisons/

Newcomb, S. (2018, September 12). 'Canada' and the 'United States' are in Turtle Island. Indian Country Today. https://indiancountrytoday.com/archive/canada-and-theunited-states-are-in-turtle-island

New Youth. (2019). What's the history of anti-Black racism in Canada. https://newyouth.ca/en/resources/immigration/more-resources/whatshistory-anti-black-racism-canada

Noe-Bustamente, L., Mora, L., \& Lopez, M. H. (2020). About one-in-four U.S. Hispanics have heard of Latinx, but just 3\% use it. Pew Research Centre. https://www.pewresearch.org/hispanic/wp-content/uploads/sites/5/2020/08/ PHGMD_2020.08.11_Latinx_FINAL.pdf

Norwood, A. (2017). Rosa Parks. National Women's History Museum. https://www.womenshistory.org/education-resources/biographies/rosa-parks 
Ontario Association of Children's Aid Societies (OACAS). (n.d.). Poverty and child welfare. https://oacas.libguides.com/c.php?g=702168\&p=4993507

Ontario Human Rights Commission. (n.d.a). Ageism and age discrimination (fact sheet). http://www.ohrc.on.ca/en/ageism-and-age-discrimination-fact-sheet

Ontario Human Rights Commission. (n.d.b). Racial discrimination, race and racism (fact sheet). http://www.ohrc.on.ca/en/racial-discrimination-race-and-racism-factsheet

Osman, J. (2017, November 22). Colonialism, explained. Teen Vogue. https://www.teenvogue.com/story/colonialism-explained

Ostroff, J. (2019, December 2). Colonial Canada had slavery for more than 200 years. And yes, it still matters today. HuffPost Canada. https://www.huffingtonpost.ca/ 2017/06/17/slavery-canada-history_n_16806804.html

Oxford University Press. (2019). Commonsense knowledge. Encyclopedia.com. https://www.encyclopedia.com/social-sciences/dictionaries-thesaurusespictures-and-press-releases/commonsense-

knowledge\#: :text=commonsense\%20knowledge\%20This\%20refers\%2C\%20unsur prisingly,our\%20everyday\%20world\%20and\%20activities.\&text=For\%20\%C3\%89m ile\%20Durkheim\%2C\%20sociology\%20must,knowledge\%20of\%20the\%20social\%2 0world.

Parrott, Z. (2020). Indian Act. The Canadian Encyclopedia. https://www.thecanadianencyclopedia.ca/en/article/indian-act

Pettit, J. L. (1997). "To Christianize and civilize": Native industrial schools in Canada [Unpublished dissertation]. Department of History, University of Calgary.

Planned Parenthood. (2021a). What is homophobia? https://www.plannedparenthood.org/learn/sexual-orientation/sexualorientation/what-homophobia

Planned Parenthood. (2021b). What is transphobia? https://www.plannedparenthood.org/learn/gender-identity/transgender/whatstransphobia

Powless Jr., I. (2012). Treaty making. Honor the Two Row. http://honorthetworow.org/ wp-content/uploads/2012/01/IrvPowlessTreaty-makingWEB.pdf

Raiku, N. (2018). Orientations on disorienting dilemma: Towards an integral conceptualization between theory and practice [Conference presentation]. 3rd Conference of ESREA's Network Interrogating Transformative Processes in Learning 
and Education: 'Contemporary Dilemmas' and Learning for Transformation, Milan, Italy.

Rhenault, D. (2011). Solving the "Indian problem:" Assimilation laws, practices \& Indian residential schools. Ontario Métis Family Records Centre. https://www.omfrc.org/ wp-content/uploads/2016/06/specialedition8.pdf

Rosario, M., de Guzman, T., Durden, T. R., Taylor, S. A., Guzman, J. M., \& Potthoff, K. L. (2016). Cultural competence: An important skill set for the 21st century. University of Nebraska-Lincoln Extension Publications. https://extensionpublications.unl.edu/ assets/html/g1375/build/g1375.htm

Roy, P. E. (2020). Internment in Canada. The Canadian Encyclopedia. https://www.thecanadianencyclopedia.ca/en/article/internment

Sakamoto, I. (2007). A critical examination of immigrant acculturation: Toward an antioppressive social work model with immigrant adults in a pluralistic society. British Journal of Social Work, 37(3), 515-535. https://doi.org/10.1093/bjsw/bcm024

Sakamoto, I., Wei, Y., \& Truong, L. (2008). How do organizations and social policies "acculturate" to immigrants? Accommodating skilled immigrants in Canada. American Journal of Community Psychology, 42(3-4), 343-354. https://doi.org/ $\underline{10.1007 / \mathrm{s} 10464-008-9197-5}$

San Diego Foundation. (2016, March 24). What is social justice? https://www.sdfoundation.org/news-events/sdf-news/what-is-social-justice/

Schwinghamer, S. (2021). The colour bar at the Canadian border: Black American farmers. Canadian Museum of Immigration at Pier 21. https://pier21.ca/research/ immigration-history/the-colour-bar-at-the-canadian-border-black-americanfarmers

Sears, A. (1999). The "lean" state and capitalist restructuring: Towards a theoretical account. Studies in Political Economy, 59(1), 91-114. https://doi.org/10.1080/ $\underline{19187033.1999 .11675268}$

Shanahan, D. (2019, November 27). Finders keepers - The Doctrine of Discovery. Anishinabek News. https://anishinabeknews.ca/2019/11/27/finders-keepers-thedoctrine-of-discovery/

Shannon, D., \& Rogue, J. (2009). Refusing to wait: Anarchism \& intersectionality. Zabalaza Books. $\quad$ https://libcom.org/library/refusing-wait-anarchismintersectionality

Shepard, R. B. (1983). Diplomatic racism, Canadian government and Black migration from Oklahoma, 1905-1912. Great Plans Quarterly, 1738, 5-16. 
https://digitalcommons.unl.edu/cgi/

viewcontent. . gi ?article $=2737 \&$ context $=$ greatplainsquarterly

Shields, J., Drolet, J., \& Valenzuela, K. (2016). Immigrant settlement and integration services and the role of nonprofit service providers: A cross-national perspective on trends, issues, and evidence [Unpublished working paper]. Ryerson University.

Slattery, B. (2015). The Royal Proclamation of 1763 and the Aboriginal Constitution. In T. Fenge \& J. Aldridge (Eds.), Keeping promises: The Royal Proclamation of 1763, Aboriginal rights, and treaties in Canada (pp. 14-32). McGill-Queen's University Press.

Slave Voyages Project. (n.d.). Trans-Atlantic slave trade - Introductory maps. https://www.slavevoyages.org/voyage/maps\#introductory-

Smith, D. (2020). War Measures Act. The Canadian Encyclopedia. https://www.thecanadianencyclopedia.ca/en/article/war-measures-act

Smit, M. (2019). Peter Henderson Bryce. The Canadian Encyclopedia. https://www.thecanadianencyclopedia.ca/en/article/peter-henderson-bryce

Snowdon, W. (2017, February 6). 'Secret Alberta': New documentary brings Amber Valley back to life. CBC News. https://www.cbc.ca/news/canada/edmonton/ secret-alberta-new-documentary-brings-amber-valley-back-to-life-1.3968766

Starblanket, T. (2008). Treaties: Negotiations and rights. University of Saskatchewan Digital Archives. http://digital.scaa.sk.ca/ourlegacy/exhibit_treaties

The Starfish. (2020, June 29). Environmental racism in Canada: What you might not now. https://thestarfish.ca/journal/2020/06/environmental-racism-in-canadawhat-you-might-not-know-2/

Statistia. (2020). Home ownership in the U.S. in 1st quarter of 2020, by ethnicity. https://www.statista.com/statistics/500069/homeownership-rates-usa-byethnicity/

Statistics Canada. (2021). Data products, 2016 census. https://www12.statcan.gc.ca/ census-recensement/2016/dp-pd/index-eng.cfm

Statistics Canada. (2020). Study: Increasing selection of immigrants from among temporary foreign workers in Canada. https://www150.statcan.gc.ca/n1/en/dailyquotidien/200722/dq200722b-eng.pdf?st=tP5Wq440

Statistics Canada. (2008). Earnings differences between immigrants and the Canadianborn: The role of literacy skills - ARCHIVED. https://www150.statcan.gc.ca/n1/en/ pub/81-004-x/2008005/article/10798-eng.pdf?st=wyKfbdQH 
Stones, S. (2021, June 4). Brandon investigation underway on unmarked residential school graves. CTV News. https://winnipeg.ctvnews.ca/brandon-investigationunderway-on-unmarked-residential-school-graves-1.5457227

Stote, K. (2019). Sterilization of Indigenous Women in Canada. The Canadian Encyclopedia. https://www.thecanadianencyclopedia.ca/en/article/sterilizationof-indigenous-women-in-canada

Te'Mexw Treaty Association. (n.d.). The lead up to the Douglas Treaties. https://temexw.org/moderntreaties/douglas-treaties/

Thibodeau, S., \& Peigan, F. N. (2007). Loss of trust among First Nation people: Implications when implementing child protection and treatment initiatives. First Peoples Child \& Family Review, 3(4), 50-58.

Thobani, S. (2007). Exalted subjects: Studies in the making of race and nation in Canada. University of Toronto Press.

Truth and Reconciliation Commission of Canada. (2015a). Calls to action. http://trc.ca/ assets/pdf/Calls to Action English2.pdf

Truth and Reconciliation Commission of Canada. (2015b). What we have learned: Principles of truth and reconciliation. http://www.trc.ca/assets/pdf/ Principles English Web.pdf

Union of Ontario Indians. (2013). An overview of the Indian residential school system. https://www.anishinabek.ca/wp-content/uploads/2016/07/An-Overview-of-theIRS-System-Booklet.pdf

United Nations. (n.d.). International Human Solidarity Day 20 December. https://www.un.org/en/observances/human-solidarity-day

University of British Columbia. (2009a). Reserves. Indigenous Foundations. https://indigenousfoundations.arts.ubc.ca/reserves/

University of British Columbia. (2009b). Royal Proclamation, 1763. Indigenous Foundations.

https://indigenousfoundations.arts.ubc.ca/

royal_proclamation_1763/

University of British Columbia. (2009c). Sixties Scoop. Indigenous Foundations. https://indigenousfoundations.arts.ubc.ca/sixties_scoop/

University of British Columbia (2009d). The residential school system. Indigenous Foundations.

https://indigenousfoundations.arts.ubc.ca/

the residential school system/

University of the Fraser Valley. (2021). Komagata Maru centennial commemoration: 
History. South Asian Studies https://www.southasiancanadianheritage.ca/koma-gata-maru/history/

Wittmeier, B. (2020, February 5). History of black immigration sheds light on forgotten connection between Alberta and Oklahoma. University of Alberta Folio. https://www.ualberta.ca/folio/2020/02/history-of-black-immigration-shedslight-on-forgotten-connection-between-alberta-and-oklahoma.html

The Working Centre. (n.d.). Survival job/Professional work. https://www.theworkingcentre.org/survival-jobprofessional-work/364

Yarhi, E. (2019). MS St. Louis. The Canadian Encyclopedia. https://www.thecanadianencyclopedia.ca/en/article/ms-stlouis?gclid=CjwKCAjwy42FBhB2EiwAJY0yQpySxAqvR9rV0EKc0AodrsyYWYSrkDJvMy6xt9K F3F1erg8QkYghoC8PsQAvD BwE

Yun, T., Agecoutay, C., \& Jones, A. M. (2021, May 30). Tiny shoes and lowered flags: Memorials spread for 2015 First Nations children found buried in mass grave in B.C. CTV News. https://www.ctvnews.ca/canada/tiny-shoes-and-lowered-flagsmemorials-spread-for-215-first-nations-children-found-buried-in-mass-grave-in$\underline{\mathrm{b}-\mathrm{c}-1.5448699}$

\section{Media Attributions}

APTN News. (2020, January 23). The legacy of Idle No More put InFocus | APTN InFocus [Video]. YouTube. https://www.youtube.com/watch?v=V1DFyCG86ic

CBC News: The National. (2017, December 10). How Idle No More sparked an uprising of Indigenous people [Video]. YouTube. https://www.youtube.com/ watch?v=TYf75dKON6k

CBC News: The National. (2012, December 19). Idle No More [Video]. YouTube. https://www.youtube.com/watch?v=SpBdZtwH_xc

Channel 4 News. (2020, June 15). Black Lives Matter explained: The history of a movement [Video]. YouTube. https://www.youtube.com/watch?v=YG8GjlLbbvs

Henderson, A. (Executive Producer). (2021). Firsthand: The skin we're in [TV series]. 90th Parallel Productions; Canadian Broadcasting Corporation. https://www.cbc.ca/firsthand/m_features/heres-what-you-need-to-knowabout-carding 
TEDx Talks. (2018, April 25). \#BlackLivesMatter | Kennedy Cook | TEDxYouth@Dayton [Video]. YouTube. https://www.youtube.com/watch?v=Sd-VUOgS3rE

Woodward, S. (2013, January 10). Idle No More short documentary - GROUNDED NEWS [Video]. YouTube. https://www.youtube.com/watch?v=IzXI7aznBtc 



\section{CHAPTER 3: MIGRATION-RELATED TRAUMA AND REFUGEE MENTAL HEALTH IN THE CANADIAN RESETTLEMENT SECTOR}





\title{
Overview
}

\author{
CHRISTINA HAMER
}

In this chapter, you will learn about concepts and types of migration-related trauma associated with forced migration. As you work through the chapter, you will be able to explore the challenges for researchers, policymakers, and frontline support workers in obtaining, understanding, and categorizing information about people's experiences during forced migration. Understanding these challenges is critical to understanding why it may be difficult to recognize and support a person who has experienced migration-related trauma. You will also learn about Canadian immigration streams designed for the resettlement of refugees with greater support needs as a result of migration-related trauma. Finally, you will learn about the challenges newcomers face in accessing mental health services in the Canadian healthcare system, the recommendations researchers have made to address those challenges, and some good practices already occurring across Canada.

When you finish the chapter, you will understand that migration-related trauma is a concept that, while heavily debated and historically dependent, helps us understand some of the challenges people face when forced to migrate and helps us find ways to better support those peoples' resettlement in new communities.

Specific Learning Outcomes

Upon successful completion of this chapter, you will be able to

1. Define types of migration-related trauma

2. Recognize types of migration-related trauma

3. Identify social determinants of health and factors that create resilience in people forced to migrate

4. Identify drivers of forced migration

5. Differentiate arguments for the classification of drivers of forced migration

6. Identify Canadian immigration programs that can support newcomers with higher health support needs 
7. Analyze the intersections and roles of multiple stakeholders in private refugee sponsorship situations

8. Identify potential stakeholders in community services related to newcomer mental health supports

9. Identify good practices occurring across Canada around refugee and newcomer mental health

10. Identify access to mental health challenges for newcomers in Canadian health care 
Key Terms 


\begin{tabular}{|c|c|}
\hline Asylum seeker & $\begin{array}{l}\text { An individual who is seeking international protection. In countries } \\
\text { whose claim has not yet been finally decided on by the country in } \\
\text { ultimately be recognized as a refugee, but every refugee is initially }\end{array}$ \\
\hline Forced migration & $\begin{array}{l}\text { A general term that refers to the movements of refugees and inter } \\
\text { as people displaced by natural or environmental disasters, chemic } \\
\text { Forced migration is distinguished from voluntary (sometimes calle } \\
\text { motivation to leave the place of residence. }\end{array}$ \\
\hline Migrant & $\begin{array}{l}\text { A person who is outside their country of origin. Sometimes this te } \\
\text { birth, including people who have been Canadian citizens for deca } \\
\text { people with temporary status or no status at all in the country wh }\end{array}$ \\
\hline Newcomer & $\begin{array}{l}\text { A person who has official permanent resident status in Canada. Th } \\
\text { resident status regardless of the immigration stream through whi } \\
\text { legal one, so the term is used broadly but does not have a legal so }\end{array}$ \\
\hline Protective factors & $\begin{array}{l}\text { The Canadian government lists some life circumstances as factors } \\
\text { - Living in a safe community that is accepting, supportive, and } \\
\text { - Having healthy and supportive relationships, which help you } \\
\text { - Geting in housing that is clean and well maintained } \\
\text { - Having a steacady job } \\
\text { Other factors that can protect mental health have been catalogue } \\
\text { - Socio-demographic factors: gender, age education level, time } \\
\text { - Psychosocial factors: acculturation in host country, faith in a } \\
\text { support from community and peers, access to health care an }\end{array}$ \\
\hline Refugee & $\begin{array}{l}\text { A person who meets the eligibility criteria under the applicable re } \\
\text { refugee instruments, under UNHCR's mandate, and/or in nationa } \\
\text { A person who, owing to well-founded fear of being persecuted for } \\
\text { particular social group or political opinion, is outside the country } \\
\text { unwilling to avail himself of the protection of that country; or why } \\
\text { former habitual residence as a result of such events, is unable or, }\end{array}$ \\
\hline Resilience & A dynamic process of positive adaptation to significant adversity. \\
\hline
\end{tabular}



in society, such as income, education, or employment. Experience important social determinants of health for certain groups such a 


\section{Introduction}

Do you know how many Canadians were born outside Canada?

Do you know what kind of challenges there are in starting your life over again in a new country, whether you are nine years old or ninety?

Canada's population has become increasingly foreign-born. According to the 2016 census, $21.6 \%$ of Canada's 35.2 million people were born outside the country. That meant 7.6 million Canadians came to Canada as immigrants. So, the success and wellbeing of those people who immigrated to Canada accounts for the success and wellbeing of one-fifth of all Canadians and all the other people who are impacted by that success.

The challenges associated with moving your life permanently to another country can include managing in a completely new language, having to reinvent yourself to gain employment, needing to create completely new social networks, and trying to understand how to do everyday tasks in an entirely different

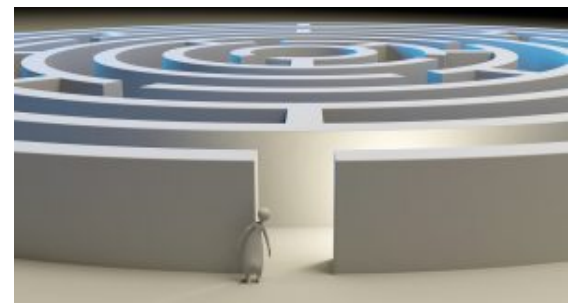
cultural context. At the very least, tackling these challenges requires a lot of effort and energy. In cases where people are forced to leave their home countries because of violent conflict and persecution, the challenge to start over is even greater due to the added stress of loss and migration-related traumatic experiences.

Canada is one of many countries that commit to resettling people who are forced to leave their homes because of conflict and persecution. People who are resettled are legally recognized as refugees under the UN Convention Relating to the Status of Refugees and Canada's Immigration Refugee and Protection Act (IRPA). Resettled refugees are included in the 7.6 million Canadians born outside Canada. Sheath et al. (2020) explain that

" $[t]$ he mental health of refugees is not only important for refugees themselves, but also important for the mental health of host societies, overall social health 
in the host countries, and the human and financial resources of those host countries" (p. 8).

By the end of this chapter, you should be able to recognize common migration experiences often associated with migration-related trauma and the resources that create resilience for migrants. You should be able to identify and compare the social determinants of health and the challenges newcomers face in accessing mental health services in Canada. You will also learn about some good practices in refugee and newcomer mental health services that are occurring in Canada.

Learning Activity 1: Self-Reflection - Expectations of Yourself and this Chapter

Before you begin working through this chapter, it may be useful to write down a few details about your current knowledge and expectations about what you will learn. There will be another selfreflection activity at the end of the chapter that you can compare with what you write in this activity. Feel free to answer directly or use the following questions as a guide for reflection:

1. When you read the word "trauma," what do you understand it to mean?

2. Do you think that a person can recover from a traumatic experience?

3. What resources do you think a person needs to help them cope with a traumatic experience?

4. When you read the term "resilient," what do you understand it to mean?

5. When you read the term "mental health"' what do you understand it to mean?

6. What do you hope to do with the knowledge from this chapter?

7. Whose "job" is it to help new immigrants to Canada? 
Image Credit

Maze by qimono, Pixabay licence

146 | Introduction 


\section{Migration-Related Trauma}

\section{What is Migration-Related Trauma?}

According to the Centre for Addiction and Mental Health (CAMH) in Toronto, "Trauma is the lasting emotional response that often results from living through a distressing event" (CAMH, n.d.). The CAMH definition goes on to explain that

"[e]xperiencing a traumatic event can harm a person's sense of safety, sense of self, and ability to regulate emotions and navigate relationships. Long after the traumatic event occurs, people with trauma can often feel shame, helplessness, powerlessness, and intense fear" (CAMH, n.d.).

Migration-related trauma, at first glance, is what is sounds like-the trauma that a person may experience in relation to migration. There are common experiences found in forced migration stories. Yaylaci (2018, pp. 2-3) lists a number of events and factors linked to trauma common in forced migration experiences:

- Exposure to war-related events

- Unknown fate of missing family members

- Exposure to multiple traumatic events

- Perception of the degree of personal threat

- Level of personal involvement in the event

- Pre-existing individual vulnerability

- Poor mental health of family members

- Incarceration or political persecution of family members

- Fleeing alone without accompanying family members

- Low social support in the country of asylum or postmigration country

- Financial difficulties

- Unemployment

- Social isolation

- Language problems 
- Difficult asylum procedures

People who experience migration-related trauma can suffer from anger, depression, anxiety, the inability to set and pursue goals, and PTSD. Nickerson et al. (2014) argue that many of the symptoms associated with psychological disorders are mediated by emotional dysregulation, or emotional expression that is different from or outside of the socially accepted range of expression. Post-migration stressors in the country of asylum and/or resettlement are also understood to further influence a person's response to trauma. Steel et al. (2017) state that "[c]hronic stress after arriving in the host country associated with resettlement leads to poorer quality of life and health (p. $524)$.

Trauma and migration-related trauma are specific terms that can determine what official immigration paths migrants are eligible for and what support services they may receive both during and post-migration. Schouler-Ocak (2015) explains that studies on trauma and migration

"report on the multiple and highly complex stressors with which refugees are often faced ... [which] might be experiences of traumatization before, during, and after the actual journey of migration. If they succeed in leaving the crisis area, this journey is often a long and tortuous one during which they may be exposed to other traumatic events" (p. 4).

To more fully understand how and when experiences might be classified as traumatic, it is important to understand the term "trauma" and how it is used in relation to migration, as well as protective factors that may influence how a trauma is experienced. Pedersen (2015) examines the history of the term "trauma" and how it was originally a term that referred to purely physical phenomena. Then, over time, the term became used in relation to psychological and emotional experiences related to physical trauma and violence. Now the term is also used to refer to purely psychological experiences.

Throughout the historical transformation in the use of the term "trauma," how trauma is recognized and classified also evolved. Pedersen (2015) notes that trauma can now be understood as a cultural and individual experience. That is,

"It is now generally accepted that victims react to the experience of trauma according to the meaning that this represents for them, and therefore not all reactions should be regarded as necessarily pathological, or abnormal. In 
fact, it can be argued that many of the reactions to trauma are 'normal' and represent a rather healthy response from which defence mechanisms evolve and healing processes are constructed" (p. 12).

This perspective that the experience of trauma is cultural extends from the individual experience to a societal level. Pedersen goes on to explain how societal perspectives and responses can mediate how a person experiences a traumatic event:

"[S]ociety and culture assign significance and attach meanings to the traumatic event, which can give to and make sense of the traumatic experience, so that in turn it could somehow mitigate, reduce, or even amplify its impact" (p. 12).

Trauma is a concept mediated by a number of factors, including physical and psychological phenomena, violence, migration experiences, culture, and society. Protective factors can be individual, cultural, and social. They can help a person adapt to stressors and trauma. We need to understand trauma to understand how it can affect measures of mental health in migrants who have experienced it.

\section{Determinants of Migrant Mental Health}

Mental health is another concept that has become common to everyday language. The World Health Organization (WHO) in the Social Determinants of Mental Health (2014) defines mental health as

"a state of well-being in which every individual realizes his or her own potential, can cope with the normal stresses of life, can work productively and fruitfully, and is able to make a contribution to her or his community" (p. 12).

You will notice that this definition includes the capabilities that a person would have with good mental health and includes stated action. Although there are many definitions and frameworks for mental health, for the purposes of this chapter, we will be using this one.

Because trauma may be culturally framed, the definition of mental health may be as well. As you continue through this chapter, consider the strengths and complications that might come from a particular definition. Although we need definitions and classifications to direct our actions and help us collaborate to promote and support health and well-being, mental health is not an end state, but rather exists on a spectrum, from greater to poorer mental health. People fluctuate along this continuum throughout their lives. Migration is one of many important factors influencing a person's mental health. 
The IOM model of the social determinants of mental health uses the Social Determinants of Health (SDOH) framework crosscut by situations in forced migration. The SDOH framework builds on the idea that the determinants of mental health are social in nature.

The International Organization for Migration (IOM) captured the Social Determinants of Health in a graphic that includes details on the situational effects of the forced migration journey. To view this graphic, please go to the Social Determinants of Migrant Health.

Social determinants of mental health include "gender, age, ethnicity, income, education, or geographic area of residence" (WHO, 2014, p. 16). McKenzie et al. (2014) outlines how those social determinants may exist as pre- and post-migration factors and their impact on an individual's mental health:

"Among the pre-displacement characteristics, region of origin, higher levels of education, higher age, higher socioeconomic status, being from a rural area, and, to a lesser extent, female gender were associated with lower levels of mental health. The factors showing lower levels of mental health after flight and displacement were low levels of economic opportunity (work permit, access to employment, retaining socioeconomic status), living in institutional or temporary private accommodations, being internally displaced, being repatriated, and coming from a region with an ongoing conflict" (p. 36).

Here, pre-displacement refers to pre-migration. You will note that Aichberger also expands on the idea of "geographic area of residence" to include type of accommodation and ongoing conflict as characteristics of that residence.

While trying to understand what migration experiences or factors affect migrant mental health, researchers have examined whether the timing or the type of trauma has the strongest impact on mental health. Many studies look at the effects of trauma that occur before people are forced to move from their homes or while they are migrating. Other studies look at the effects of the post-migration context, or what life is like for migrants who have the chance to resettle in a new country.

Although migrants who experienced traumatic events pre-migration "were more likely to suffer mental health problems in their resettlement country" (Chen et al., 2017, p. 6), "resettlement-related post-migration stressors were the most important correlates of humanitarian migrants' mental health" (Chen et al. 2017, p. 9).

Chen et al. (2017) looked at humanitarian migrants who resettled in Australia. The study found that the two factors that moderated migrants' post-migration mental health were "loneliness" and "social integration or isolation" (p. 10). Migrants who experienced pre-migration trauma, and then also experienced loneliness and social isolation in their resettlement country, reported lower levels of mental health. This 
begs the question, what about migrants who experience pre-migration trauma and then experience social integration and support in their resettlement country?

Learning Activity 2 : Matching Migration-Related Trauma and Factors with SDOH Categories

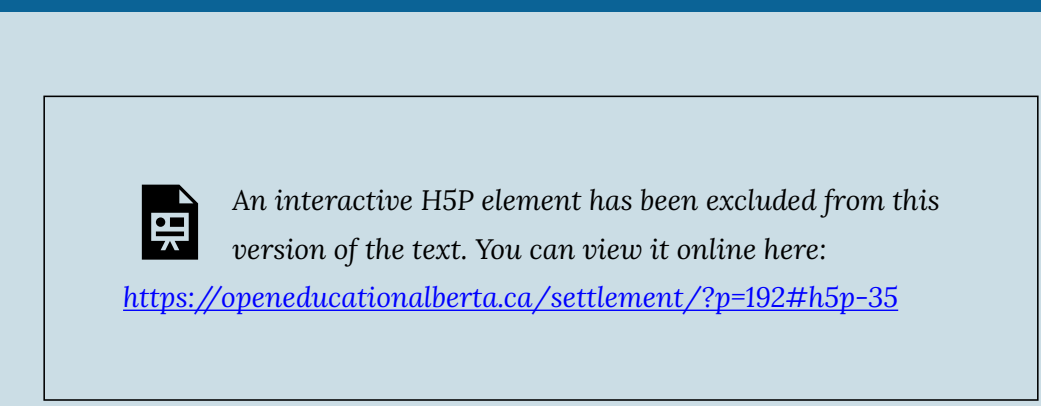

\section{Resilience and the "Resilient Migrant"}

In the field of psychology, resilience may describe a person's ability or set of resources that allow them to adapt and cope with a highly stressful situation. Resilience can come from individual characteristics as well as socio-demographic factors such as social network, the stability that comes from enduring relationships. However, the "resilient migrant" has become a characterization of a migrant whom receiving countries might deem an asset to the economy. Although both uses of "resilience" appear positive, as with other terms, it is critical to examine how the definition can be used to evaluate a migrant's story when they make a refugee claim and the potential consequences of that evaluation.

In Gatt et al. (2019), "[r]esilience is a dynamic process of positive adaptation to significant adversity." McKenzie et al. (2014) describe some refugees as people who "use their own resources and coping strategies to deal with the difficulties encountered in their country of origin, during migration, in their new host country, and in the asylum process. They are resilient people" (p. 183). In a study of unaccompanied refugee minors (URMs) in the United States, Carlson et al. (2012) looked at "sources of resilience among URMs that have allowed them to adapt and even thrive in a vastly different cultural environment despite exposure to multiple 
risks" (p. 1). Carlson also warns that we may not be able to see a person's resilience if their trauma story is pathologized.

An American Psychology Association report (2009) published as an update for mental health professionals discusses the dangers of the Western medical model and pathologizing trauma:

"[T]he Western medical model frames adversity and suffering in terms of psychopathology rather than as a legitimate response to stress and upheaval. A clinician may experience pressure to emphasize vulnerability and victimization over resilience in the clinical formulation of a refugee client's condition in order to request other services or support an application for asylum. This kind of emphasis then suggests that the individual's reaction to war and organized violence is abnormal rather than an expected response to severe trauma" (p. $10)$.

Over the past decade, more studies have considered what types of responses to trauma are natural psychological coping mechanisms. One long-term study by Beiser (2014) on Southeast Asian and Sri Lankan Tamil refugees in Canada found that "[s]uppression of traumatic memory may be an effective coping strategy in the short and medium term aftermath of trauma" (p. 79). The study went on to describe how time and social resources were potential sources of resilience for refugees who had experienced migration-related trauma. Challenge and the risk of mental disorder came when individuals began to remember traumatic experiences. In some cases, this remembering did not begin to occur until after a decade in Canada (pp. 79-80). Social networks that included "like-ethnic community," spouses, and non-kin relationships such as community organization staff or work colleagues provided potential sources of resilience through relationships. Prolonged relationships appeared as a highly effective protective factor (p. 81).

These examples of resilience take into account that individuals may have different experiences of trauma, different migration stories, and different potential sources of resilience. In contrast, a new characterization of the "resilient migrant" has emerged based on a stereotypical image. Although the characterization may certainly have some basis in examples of individuals, Faist (2020) notes that "[i]t is the resilient migrant who has emerged in policy discourse as the ideal-typical figure ... who adapts"(p. 249). Faist continues that characterizing a resilient migrant as the ideal can mean that countries create policies that expect migrants to show resilience rather than creating structures or programs that recognize the trauma that is so often part of the forced migration experience (p. 250). Additionally, the problem with the resilient migrant ideal-type is that it may be based on the short- and mid-term responses that migrants can have to trauma when they might be using strategies such as suppressing memories. This ideal-type may not be informed by the longer-term mental health responses people have had to trauma. 


\section{Fatima: Potential Trauma During Migration}

Fatima is a single mother with two children, a seven-year-old son, Ahmed, and a 10-year-old daughter, Aysha. The family does not know where Mohamed, Fatima's husband is; he went missing in their home country during a night of violence in their area. Fatima and the children fled when the fighting and violence overtook their city and their neighbourhood.

Fatima and the children fled with very little planning or preparation. They took a local bus to the land border of a nearby country. They each took one small suitcase, then walked across the border, registering with authorities at the crossing. They walked to a UNHCR refugee camp that was 12 kilometres inside the country of asylum border. Fatima and the children stayed in the refugee camp for two months. When Fatima received her official permit to work and education permission for her children, the three of them moved to a nearby town. They moved into an apartment with another single mother with three children who were also from Fatima's home country and had fled the violence.

Fatima started working informally as a seamstress. She has no official position despite having formal permission to work. She goes to a small textile workshop, and each morning they tell her whether they have work for her or not. Aysha and Ahmed go to the local public school but do not yet speak the national language. There are some very recently appointed language support teachers in the school to help children like Aysha and Ahmed; however, all classes are delivered in the national language. 
Local people in the apartment building and neighbourhood have little to no experience with foreigners and often cluster and whisper to one another as Fatima or the children walk in or out of the building. Fatima is polite and smiles and nods slightly when she sees people in the building lobby, but she is not able to greet them. Like her children, Fatima does not speak the language of the country of asylum.

There is a local medical clinic that has a doctor and nurses who specialize in refugee health issues; however, they only speak the local language. A few people in the community can provide translation support, but Fatima and her children have not accessed the health clinic or translation supports because they do not know anything about the translators and are concerned about sharing very personal information with strangers.

\section{Case Study Questions}

Use the questions below to consider how traumatic events may be viewed differently by a person depending on their individual character, social circumstances, and sources of resilience. Discuss your responses with others working through this chapter.

1. Do you think Fatima and her children may have experienced trauma?

2. What parts of their migration story may have included traumatic experiences?

3. What elements of Fatima's current situation might act as prolonged stressors?

4. Knowing that trauma can be determined by the perspective of the person experiencing it, what thoughts or perspectives might Fatima have that would make her migration experiences seem less traumatic to her?

5. In what ways do you think Fatima and her children may have shown resilience along their journey and in their current 
situation in the country of asylum?

6. Do Fatima and the children have any potential social resources that may increase their resilience? 


\section{Forced Migration}

Definitions of trauma and mental health help us understand the experiences of people who are forced to migrate, but we also need to understand the international laws, policies, and perspectives that countries use to determine how they will respond to those migrants. Forced migration is considered the opposite of voluntary migration. But who decides what constitutes volition or choice?

Forced migration encompasses the idea that people have no choice but to flee their home region or country to seek safety elsewhere. In the case where a country cannot or will not keep its own citizens safe, as may occur in civil war, then those people who flee to seek safety may request formal asylum in the nearest country that is a signatory to the 1951 Convention Relating to the Status of Refugees and the 1967 Protocol, often referred to together as the UN Convention on Refugees. Not all countries are signatories to the Convention, and even those who are signatories decide how they will incorporate the international law into their national laws and immigration policies.

\section{Drivers of (Forced) Migration}

The drivers of human migration have been long discussed and categorized by policymakers, lawyers, researchers, and more. For migrants and policymakers, the challenge is in navigating the practical applications of those discussions and categories. Migrants must figure out how they fit into laws and policies in order to migrate. Policymakers must interpret and apply immigration laws and policies as part of governing a country. The additional challenge for anyone trying to discern the drivers of forced migration is the question of what constitutes "forced" versus "voluntary." Currently, conflict and persecution are legally coded as drivers of forced migration. Natural resource scarcity, such as access to arable land or clean water, and social resource scarcity, such as access to employment or education, are still considered drivers of voluntary migration. People who move to find food, water, work, or other opportunities are considered voluntary (or economic) migrants trying to better their lives.

So, what happens when drivers overlap, and something such as water scarcity prompts human conflict? Which driver of migration do we consider? And are the people who move being forced or are they moving voluntarily? What if the water scarcity is caused by people in one region damming a large river that cuts off water supply to the people living downstream? What if the river has dried up because of climate change? When do we consider migration forced or voluntary? 


\section{Conflict and Persecution}

The UN Convention is often critiqued as a historical artefact. That is, the Convention was written and ratified in 1951 as an international response to the large numbers of refugees coming out of post-World War II Europe. The Convention gave countries a legal standard with which to provide immigration options for people fleeing the persecution stemming from the war. At that time, the forced migration that the international community formally recognized stemmed from persecution, particularly personal persecution as a result of international conflict:

“The term 'refugee' shall apply to any person who:

As a result of events occurring before 1 January 1951 and owing to well-founded fear of being persecuted for reasons of race, religion, nationality, membership of a particular social group, or political opinion, is outside the country of his nationality and is unable or, owing to such fear, is unwilling to avail himself of the protection of that country; or who, not having a nationality and being outside the country of his former habitual residence as a result of such events, is unable or, owing to such fear, is unwilling to return to it" (United Nations General Assembly, 1951, Chapter 1: General Provisions, Article 1 A (2)).

It was the 1967 Protocol that expanded the definition of refugee beyond events before 1951 and outside Europe. However, the definition of refugee remains tied to personal persecution. Under the Convention, then, forced migration is due to international political conflict that creates personal persecution.

Some countries do recognize refugees and offer asylum or resettlement under broader categories. Canada offers resettlement through the Country of Asylum Class for people who are outside their home country and remain "seriously and personally affected by civil war, armed conflict, or massive violations of human rights" (Government of Canada, 2014a). Some countries also offer resettlement based on humanitarian grounds (for Canada, see Humanitarian and Compassionate Consideration; for Australia, see Special Humanitarian Program).

Although there are immigration programs in many countries for migrants escaping conflict, acceptance through those programs tends to represent only a small percentage of any country's immigration. In 2018, a year when the UNHCR had identified 70.8 million people forcibly displaced (UNHCR, 2019), Canada admitted 45,758 people as Refugees and Protected Persons from out of a total of 321,035 admissions (see Annex 2: Table 4: Permanent Residents Admitted in 2018, in Canada Immigration Report 2019). That means people admitted based on the need to flee conflict and violence accounted for 14\% of Canada's immigration in 2018, whereas economic migrants represented $58 \%$. 
Historically, in 2019 and 2020, immigration numbers were uncharacteristically low across all countries and immigration streams owing to international border closures during the COVID-19 pandemic; however, the number of forcibly displaced people rose to 86.5 million by the end of 2019 (UNHCR, 2020).

The challenge for migrants fleeing conflict is in fitting the definitions that bound immigration categories. Demographic research by Conte and Migali (2019) shows that

"[t]he higher the number of deaths caused by any form of organized violence, the higher the number of first asylum applications. These results suggest that people not only flee terror and war but also violence and insecurity emerging from non-conflict-affected areas and perpetrated by different criminal actors" (p. 411).

Conte and Migali's research looked at situations where people flee conflict caused by types of organized violence that were not necessarily interstate conflict or war. If such migrants applied to be resettled in Canada based on fleeing conflict, they would be considered under the Country of Asylum Class. If you recall, one of the factors linked to trauma in the forced migration experience is a difficult asylum procedure. Narrow and limited immigration categories in receiving countries can represent a difficult asylum procedure.

Can you think of factors or situations other than international conflict that might force people to flee their homes?

\section{Climate Change}

Tim Gaynor wrote that "Climate change is the defining crisis of our time" in a UNHCR publication discussing factors affecting forced migration (Gaynor, 2020). Climate change is considered a risk multiplier in cases of forced displacement. When climate change causes natural disasters, people are often displaced for a period of time. Think of how people might have to move from their homes because of wildfires, floods, earthquakes, droughts, or rising sea levels and how such moves might be traumatic. People forced to move might experience loss of family members, loss of resources, loss of employment, loss of safe housing, and more.

People forced to move owing to climate change factors are not considered refugees according to the UN Convention and would not qualify for asylum and refugee resettlement immigration programs. In cases where a person's home country is able to provide protection, supports, and alternatives for those who flee a disaster situation, displaced individuals may be able to return to their home area after a time or resettle elsewhere within their own country. In cases where the government faces other 
challenges and is not able to provide safety and stability to those affected by a disaster, displaced individuals may be forced to seek safety by fleeing their country.

There is currently no international legal framework that recognizes climate change as a driver of forced migration. To change or amend legal frameworks, one of the challenges is in establishing a causal path between climate change and forced migration. Without a strong causal path, migrants are considered to be migrating voluntarily, which makes them economic migrants, not refugees. In special circumstances, countries can modify immigration policy to accept migrants who might not otherwise be admissible. For example, in 2010, Canada introduced special immigration measures to prioritize applications from Haitians after a devastating earthquake.

\title{
Cases to Consider
}

\section{Case Example: Canada's Special Immigration Measures - Haiti's zoro Earthquake}

\begin{abstract}
In January 2010, a 7.0-magnitude earthquake devastated Haiti. The epicentre of the quake was approximately 25 kilometres southwest of the capital, Port-au-Prince. Reports estimated that 220,000 people died in the earthquake and another 300,000 were injured, while another million were displaced by the destruction. The Haitian government was immobilized because many government officials died in the quake. The UN mission in Haiti was also destroyed.
\end{abstract}

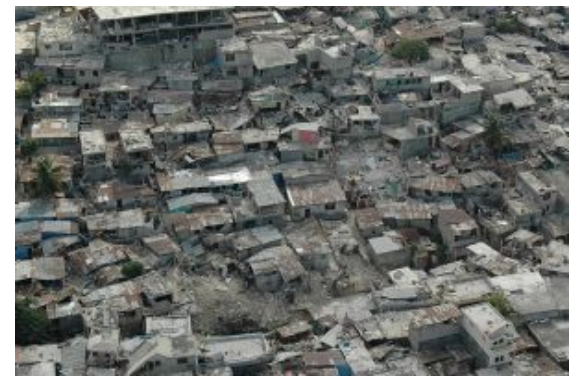

Haiti: Earthquake 2010, EU civil protection and humanitarian aid.

The Canadian government gave priority "to new and existing sponsorship applications from Canadian citizens, permanent residents, and protected persons who [had] close family members in Haiti ... [with the requirement that they] identify themselves as being directly and significantly affected by the current situation and notify Citizenship and Immigration Canada (CIC)" (Government of Canada, 2010).

Although the earthquake was not considered to be a result of climate change and the Haitians who were admitted to Canada were not called climate refugees, the special 
immigration measures Canada extended in 2010 are an example of immigration policy being modified in response to natural disaster-driven migration.

To read in detail about the 2010 Haiti earthquake and Canada's immigration responses to the event:

- Government of Canada introduces special immigration measures in response to the earthquake in Haiti (Government of Canada, 2010)

- Canada to give immigration priority to Haiti earthquake survivors (Mehler Paperny, 2010)

- Overview of the 2010 Haiti Earthquake (DesRoches et al., 2011)

Please note that the photos in the NPR article below may be very disturbing.

- Haiti in Ruins: A Look Back and the 2010 Earthquake (NPR, 2020)

Looking beyond special measures to the need for a more consistent and sustainable international framework for responding to climate crises, recent research is establishing a link between climate change and violent conflict that then may force people to migrate. Bayar and Aral (2019) report that their "findings indicate that climate change indirectly affects large-scale forced migration by igniting violent conflicts, although not all conflicts are climate-related" (p. 11). Abel et al. (2019) reinforce that "Climate change ... will not generate asylum seeking everywhere but likely in a country undergoing political transformation where conflict represents a form of population discontent towards inefficient response of the government to climate impacts" (p. 246). Their study goes further to discuss the generation of other conflict:

"The existing literature on the impacts of climate change on conflict and migration commonly assesses how environmental pressures instigate outmigration and consequently how climate change-induced migration promotes conflict in migrant receiving areas" (p. 239).

To understand how climate change may or may not produce forced international migration, consider the differences between people displaced by wildfires in Fort McMurray, Alberta, and traditional cattle herders affected by drought in northeastern Nigeria. 


\section{Case Example: Wildfires in Fort McMurray, Alberta, Canada}

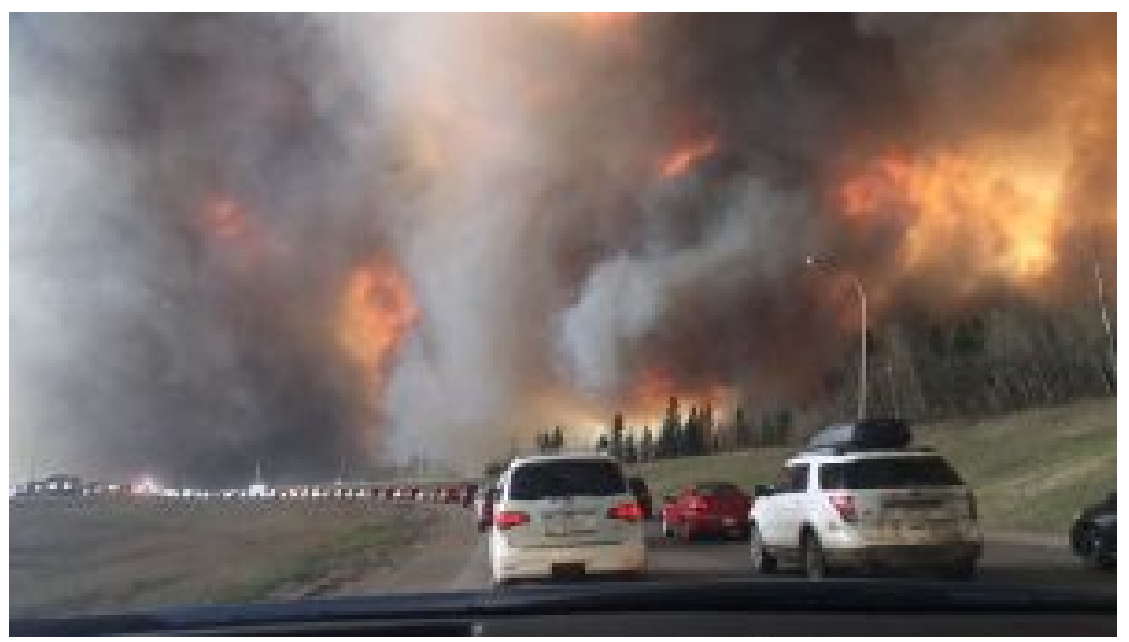

Landscape view of wildfire near Highway 63 in south Fort McMurray.

In May 2016, 88,000 people were forced to evacuate the city of Fort McMurray, Alberta. The Province of Alberta declared a state of emergency. The province requested and received assistance from the Canadian military and the Canadian Red Cross. People fled to other cities within Alberta, and some companies opened up work camps to serve as temporary shelters. Hospitals were evacuated to neighbouring locations. No one died in the fire, and residents began to return after one month. After a full year, the city was being rebuilt.

So, were the people who fled Fort McMurray climate refugees?

They were certainly internally displaced people, and they certainly reported their experiences as traumatic. The ability of the provincial and federal governments, nongovernmental organizations (NGOs), and companies to respond quickly and with significant financial resources provided Fort McMurray residents safety, shelter, and provisions. The BBC reported the Fort McMurray fire of 2016 as "the costliest insured natural disaster in Canada's history, with insurance costs totalling an estimated C\$3.6bn (US\$2.6bn/£2bn). Adding the costs to the government brings that price tag to C\$5bn" (Murphy, 2017).

However, to be considered a refugee, a person must have the need to seek safety or refuge from another country when their own country is no longer able to provide these things. Because the provincial and federal governments were able to respond as 
they did, it is unlikely that anyone would characterize the residents evacuated from Fort McMurray as refugees.

The following articles give details about the Fort McMurray fire of 2016 and the emergency and recovery responses to it:

- One Year Donor Update: 2016 Alberta Fires (Canadian Red Cross, 2017)

- BBC News - Fort McMurray one year after (Murphy, 2017)

- Wildfires Review (Government of Alberta, 2021)

- Psychosocial response and recovery evaluation (Government of Alberta, 2017)

\section{Case Example: Fulani Herders and Conflict Over Land Use in Nigeria}

Fulani nomadic cattle herders move cattle across West Africa. They have done this for centuries. The increasing population in Nigeria and climate change temperature increase and drought have shrunk available cattle grazing lands. In response to shrinking land availability, some Fulani herders have moved farther south in Nigeria, which has created conflict with farmers in the Middle Belt region. The conflicts are compounded by religious and ethnic differences between the Muslim Fulani and the predominantly Christian farmers.

There are people fleeing Nigeria, and in 2019, Canada admitted 12,602 of them (Government of Canada, 2021a). However, they were not internationally recognized as climate refugees. Nigerians are fleeing the Boko Haram insurgency that has created a regional conflict in Nigeria, Chad, Cameroon, and Niger (UNHCR, 2021b).

Imagine a person caught between the Boko Haram insurgency and the farmer-herder conflict. If they could not immigrate voluntarily for a job or education, they might be eligible to immigrate to Canada as a Country of Asylum Class Refugee. Although an argument might be made that the person was forced to migrate at least in part because of climate change, using the current legal frameworks, Canada would admit that person based on being personally affected by conflict, not climate.

To read in detail about the the Fulani herdsmen of West Africa and the conditions prompting increased conflict:

- The Climate Factor in Nigeria' Farmer-Herder Violence (interactive map) (Eberle \& Franz, n.d.)

- Stopping Nigeria's Spiralling Farmer-Herder Violence (International Crisis Group, 2020) 


\section{Conclusion}

The continuing debate around climate change and forced migration revolves around how to respond formally and legally to people whose forced migration can be linked to environmental degradation. While researchers seek to show the links between climate and other already recognized drivers of forced migration such as conflict, academics and policy analysts examine the ways that countries will need to modify their immigration programs.

The following articles give more information on how Canada might respond to climate refugees or environmental migrants:

- Canada has a moral obligation to accept climate migrants (Kaduuli, 2020)

- Environmental Migrants and Canada's Refugee Policy (Murray, 2010)

\section{Learning Activity 4: Drivers of (Forced) Migration Flashcards}

Image Credits (images are listed in order of appearance)

Haiti: Earthquake 2010 by EU Civil Protection and Humanitarian Aid, CC BY-SA 2.0 Generic licence

Landscape view of wildfire near Highway 63 in south Fort McMurray by DarrenRD, CC BY-SA 4.0 International licence 


\section{Canadian Immigration Programs for Vulnerable Migrants with High Support Needs}

The Canadian government has international commitments through the United Nations to resettle a certain number of refugees each year. Under Canada's immigration law, the Immigration Refugee Protection Act (IRPA), people forced to migrate and who qualify for international protection may have a path for resettlement in Canada either as asylum seekers or as refugees. In both cases, a person must fit the definition of a refugee, thereby being considered part of a vulnerable population. In addition, Canada has resettlement programs designed to provide increased social support to people who are identified as having higher support needs and who are referred by the UNHCR. Furthermore, although a medical exam is an admissibility requirement for any resettlement program, a person eligible as a refugee will not be refused resettlement to Canada based on any medical condition (IRPA, Part 1, Div. 4, Section 38 (1)(2)) (Government of Canada, 2019).

\section{Asylum Seekers and Refugee Claimants}

Those who arrive to Canada requesting asylum arrive to a land border and claim asylum. Once they have made their claim, they become Refugee Claimants. They may apply for a work permit and/or an education permit. Their family members may also apply for work or education permits as long as they are in Canada and have also made asylum claims. Refugee Claimants have access to health care in Canada through the Interim Federal Health Program (IFHP). The IFHP provides limited, temporary health care benefits to Refugee Claimants while they are not eligible for provincial or territorial health insurance.

Refugee claimants' legal status in Canada is connected to their official asylum claim or refugee protection claim. That official claim is considered through the Immigration Refugee Board (IRB) of Canada, which was created in 1989. Through a formal hearing, the person's asylum claim is reviewed. If their claim is recognized by the IRB, the person gains official refugee status and can immediately apply for permanent residence in Canada. As a permanent resident, that person can access settlement support services through settlement agencies, obtain health care through provincial or territorial healthcare systems using provincial or territorial health insurance, and be legally employed without any other permits.

164 | Canadian Immigration Programs for

Vulnerable Migrants with High Support 
For many refugee claimants, life remains somewhat precarious until they receive official recognition of their claim and can proceed with life in Canada as permanent residents. This means some refugee claimants do not reach a post-migration stage until they obtain permanent residence in Canada. In terms of healing from migration trauma, the asylum claim and IRB hearing process in Canada may still be seen as part of migration. The post-migration period can be seen to begin once a person receives their permanent resident status and legal access to health care, education, and employment.

\section{Resettled Refugees}

As part of Canada's international commitment to resettle refugees from abroad, Canada provides resettlement opportunities through the Refugee and Humanitarian Resettlement Program. People who are experiencing forced migration whose refugee claims have been recognized abroad by either the UNHCR or the government of a country of first asylum may be resettled in Canada through one of the following programs:

- Government Assisted Refugees (GAR) Program

- Blended Visa Office Referred (BVOR) Program

- Joint Assistance (JAS) Program

- Privately Sponsored Refugees (PSR) Program

- Collective Sponsorship (in Quebec)

All recognized refugees are considered vulnerable migrants. However, the refugees resettled through the BVOR and JAS programs come from higher-risk situations and are identified as requiring greater support needs than those who are resettled through the GAR and PSR programs.

Refugees who are resettled in Canada through the PSR program or the Collective Sponsorship Program (Quebec) are nominated or identified by the Canadians who would like to sponsor them.

Refugees resettled through the GAR, BVOR, and JAS programs are referred to Canada by the UNHCR. All refugees referred by the UNHCR "fall under UNHCR's Resettlement Submission Categories: Legal and/or Physical Protection Needs, Survivors of Torture and/or Violence, Medical Needs, Women and Girls at Risk, Family Reunification, Children and Adolescents at Risk, and Lack of Foreseeable Alternative Durable Solutions." (UNHCR, 2021). 


\section{Stakeholders in Private Sponsorship}

In private sponsorship programs, a group of Canadians or an organization choose to sponsor a refugee or refugee family. Although GARs come to Canada through the support of the Canadian government, BVOR and JAS cases have the added benefit of the social and network connections of sponsors. The presence of sponsors grows the number of stakeholders invested in a newcomer's well-being. It can also increase social dynamics among stakeholders.

Stakeholders supporting a newcomer may include the following:

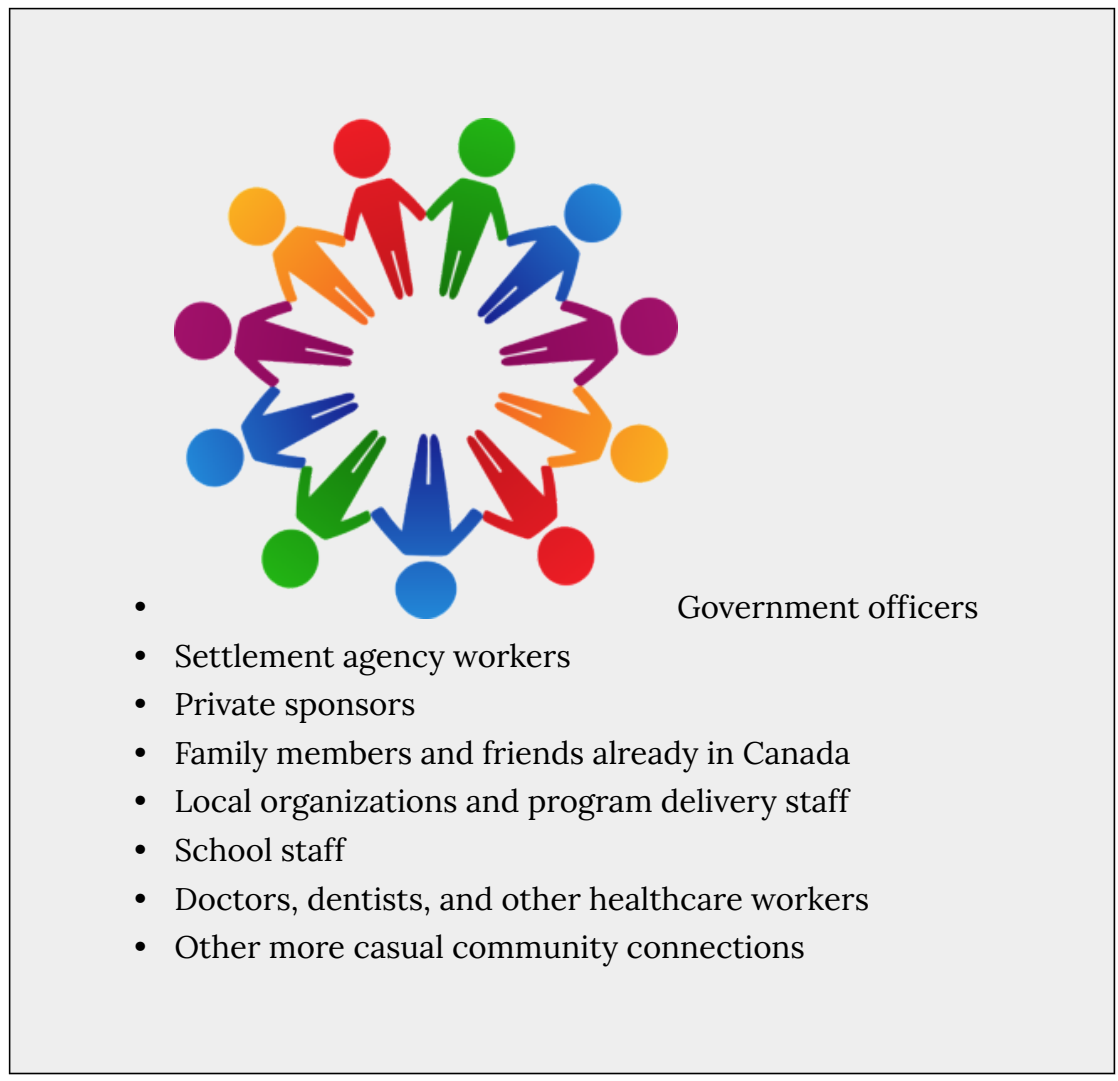

For GARs, financial support is distributed by the government directly to the newcomers and housing is organized through a settlement agency. Newcomers receive community support through settlement agency services. For privately sponsored newcomers, financial support, housing, connection with a settlement agency, and other supports are provided by the private sponsors.

166 | Canadian Immigration Programs for Vulnerable Migrants with High Support Needs 
We have seen that migrant resilience is strongly correlated with social connections and the protective factors that those connections can bring. For the stakeholders themselves, collaborating to provide those social resources to newcomers can be a challenge.

\section{Learning Activity 5: Case Study - Marjana}

\section{Marjana}

Marjana, 36, a refugee identified by the UNHCR as a woman at risk and a victim of gender-based violence and torture was resettled in Canada through the BVOR program and the support of a Sponsorship Agreement Holder $(\underline{\mathrm{SAH}})$ organization.

Marjana was greeted at the airport by the SAH coordinator, Miriam; the SAH communications person, Guy; and three volunteers (sisters) who were going to be directly involved in helping Marjana with social and tangible support needs such as budgeting, shopping, opening a bank account, and so on.

Within the first two weeks, the sisters helped Marjana connect with settlement agency staff in an organization within walking distance of where she was staying. After the intake process, a settlement worker named Gail helped Marjana enroll in the orientation program and schedule her language assessment. Gail seemed to put Marjana at ease because Marjana nervously confided in Gail about wanting to talk to a medical doctor about an issue. Marjana had not confided anything to the sisters who were supporting her through the SAH.

The SAH coordinator and the three sisters knew very little about Marjana's personal or medical situation, having received only a brief written profile with a short overview of her support needs.

It was the formal responsibility of the $\mathrm{SAH}$ and $\mathrm{SAH}$ volunteers to help Marjana find a family doctor. Gail was bound by confidentiality 
and could not share Marjana's personal information with any of the SAH contacts. Marjana was afraid of telling the sisters or SAH staff about her medical needs. She was afraid of what they would think of her. It would likely need to be the sisters who would help Marjana travel to meet a doctor for the first time.

\section{Case Study Questions}

Use the questions below to consider how collaborating stakeholders can be part of a newcomer's resources for resilience or additional stressors. Discuss your responses with others working through this chapter.

1. What stressors do you think Marjana was experiencing in her early post-migration period?

2. What resources did Marjana have that might be sources of resilience?

3. What dynamics between Gail and the sisters might increase the stressors on Marjana?

4. Is there anything Gail could do to strengthen the collaboration among the people supporting Marjana while still respecting and maintaining Marjana's right to privacy?

5. How would you feel if you were in Gail's situation?

6. How would you feel if you were in Marjana's situation?

Image Credit

[People holding hands in a circle] by OpenClipart-Vectors, Pixabay licence

168 | Canadian Immigration Programs for Vulnerable Migrants with High Support Needs 
In Canada, once a person immigrates and acquires permanent resident status, the immigration stream they came through is no longer attached to their profile or identification. This means that research and statistics on health access in Canada is not collected based on the ways in which people immigrate. So, for example, there is seldom specific information about how refugees who resettled to Canada are accessing mental health services. Academic researchers and advocacy organizations have done specific and time-limited research on newcomers accessing health services; however, those studies represent a very specific moment in time and can become outdated when there are significant changes to who is immigrating to Canada and how health care is offered and managed.

In the past 10 years, there has been more of a focus on newcomers accessing mental health supports as part of good practices for settlement, especially during the first 12 months in Canada. Although this section discusses the challenges for newcomers in accessing mental health services in Canada, internationally, Canada is known for having an excellent healthcare system. The push for improved access for newcomers is a push for equitable access to services in Canada-a striving to ensure that everyone can have quality health care.

\section{Importance of the Post-Migration Period and Trauma}

Newcomer mental health service needs are best understood through a lens of "postmigration." In research on migration-related trauma, the post-migration period can be a time of recovery, but it can also be a time of compounding trauma. Looking again at the social determinants of health, if a newcomer has a stable socio-economic situation, social and community connections, safe housing, employment, and confidence in the health and well-being of family, then they have what the research calls "protective factors" to support their resettlement process. 
By contrast, if a newcomer's resettlement experience lacks these protective factors, post-migration stressors may compound the mental health riskw related to migration trauma. In a study of humanitarian migrants in Australia, Chen et al. (2017) found that

"resettlement-related post-migration stressors were the most important correlates of humanitarian migrants' mental health. Specifically, economic stressors, loneliness, discrimination, family conflicts in [the resettlement country], concerns about family in [the resettlement country], and worrying about family or friends overseas were positively related to PTSD and severe mental illness" (p. 9).

Therefore, a newcomer's post-migration access to health care and social determinants of health not only affect their resettlement experience, but also may affect how they recover from trauma experienced before and during migration.

\section{Specific Challenges in Accessing Health Care and Mental Health Services}

Although there is still no consistent data available about how newcomers with migration-related trauma experiences access mental health services in Canada, periodic studies and surveys offer useful insights. Ozcurumez et al. (2012) show that the most common barriers to newcomers' accessing health care have included the following:

- Newcomer lack of knowledge about the healthcare system

- Location of services too far from newcomer neighbourhood

- Inappropriate fit of planned services with newcomer needs

- Health services, information, and signage not in newcomer languages

- Healthcare workers' limited experience with migrationrelated trauma

These challenges are echoed by McKenzie et al. (2014) who report that "[i]n Canada, the most often cited impediments to equitable care are language, awareness of Canadian Health System, and Good and Promising Practices Across Canada 
services, socioeconomic status, discrimination, and stigma" (p. 185). Regarding mental health in particular, "[i]n Canada it was ... noted that many immigrants were apprehensive about using mental health services because of the stigma attached to it" (pp. 111-112).

\section{Continuity and Gaps in the Mental Health Care System}

The push for more equitable access to health care and mental health services for newcomers frames internal evaluations of health services. Wylie et al. (2020) find that

"challenges to continuity of mental health care for immigrant and refugee populations are exacerbated by the complexity of and gaps within the mental health care system. Poor coordination is a significant hindrance to the healing journey, which is a problem for all patients, particularly those dealing with trauma" (p. 75).

Then, revisiting the concept of resilience in migrants, Wylie et al. (2020) note that gaps in the health services system in Canada are being filled necessarily by the newcomers themselves:

"Personal resilience amongst patients with mental illnesses is seen as essential for their ability to cope with hardship. ... system-level issues are preventing the access to timely and appropriate mental health services that could support resilience amongst those suffering mental health challenges, such as trauma" (p. 75).

It is worth remembering that some newcomers' personal resilience comes from the support of social network resources and long-term stable relationships among family members, friends, and others (see "Resilience and the 'Resilient Migrant"' in the section "Migration-Related Trauma").

\section{Cultural Competence of Healthcare Workers}

One repeated policy suggestion is that Canada's healthcare system workers need to be trained in the cultural competence (of care) in order to better assess and support the needs of resettling refugees who have experienced trauma. Sheath et al. (2020) explain that

"As a patient group, migrants are particularly susceptible to suffering as a result of a lack of cultural competence from caregivers, due to their diverse 
cultural backgrounds. ... An area of health care where cultural competence is of huge importance is in mental health, where being able to empathize with and understand your patient is key to good diagnosis and management" (p. 2).

Cultural competence training can include learning how different mental health conditions present in different cultural ways. In addition to cultural competence training, it has also been noted that although they are trained professionals with expertise, Canada's healthcare workers are not necessarily knowledgeable in how to support newcomers with migration-related trauma and resettlement needs. Wylie et al. (2018) found that "[m]any of the challenges of addressing the healthcare needs for this growing population of immigrants and refugees are therefore new and unfamiliar to care providers and health care organizations" (p. 3).

\section{Role of Settlement Sector Workers in Newcomer Resilience and Mental Health}

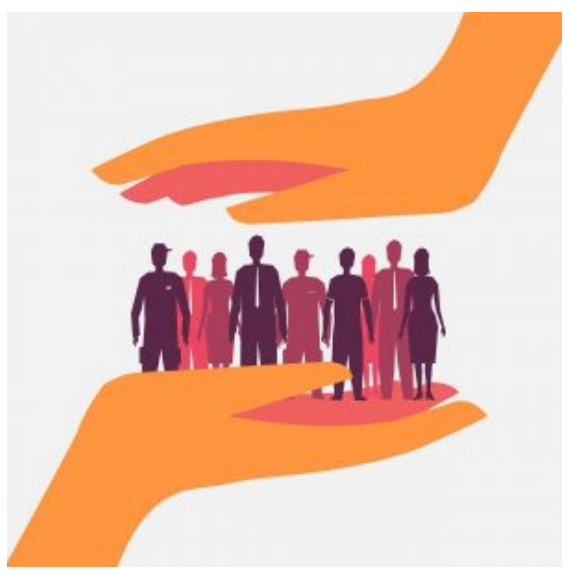

Settlement sector workers have a pivotal role in supporting the mental health of newcomers during the post-migration period. Frontline workers who are positioned as and in hubs of information exchange may help newcomers become more familiar with Canada's healthcare system, connect newcomers with language education programs, provide connections to employment programs, and act as part of a newcomer's professional social network. Settlement sector workers are positioned to support newcomers in almost every social determinant of health. Chadwick and Collins (2015) studied social support availability, urban centre size, and self-perceived mental health (SPMH) among recent immigrants to Canada. The study found that

"social support availability is significantly associated with SPMH [selfperceived mental health] among immigrants and found that immigrants living in small urban centres in Canada had significantly greater access to three types of social support [tangible social supports, opportunities for social interaction, emotional or informational support]. SSOs [settlement services organizations] provided immigrants with opportunities to access social support in various 
forms; however, provision of tangible supports appeared to be greater in the small urban centre organizations" (p. 229).

In Chadwick and Collins' (2015) study, the small urban centre organizations were noted to be in Kingston, Ontario; Victoria, BC; and Lethbridge, Alberta. So, although referred to as small, the study's threshold for a "small centre" referred to places with populations of approximately 100,000 to 300,000 . The higher level of tangible supports mentioned in the study included training in making phone calls to arrange for transportation and direct assistance (sometimes driving) to doctor's appointments. Although most organizations reported that tangible social supports (meal provision, doctor's appointment accompaniment, home care during illness) were not part of their organization's offered services, in the larger centres (Vancouver, Ottawa, Edmonton), SSOs would refer newcomers to other agencies for those services, whereas SSO staff in the smaller centres might fill gaps in services directly themselves. While this might not be a sustainable or good practice according to organizational mandates and service provision planning, the SSO staff in the smaller centres became a greater resource in newcomers' sources of resilience.

Knowing that a newcomer's social network supports the resilience that plays a key part in their mental health and well-being, can you think of three different people who might be a part of a newcomer's social or community network beyond settlement workers and doctors?

\section{Good and Promising Practices Around Newcomer Mental Health in Canada}

In 2016, the Mental Health Commission of Canada (MHCC) produced a report as part of the project on "The Case for Diversity: Building the Case to Improve Mental Health Services for Immigrant, Refugee, Ethno-cultural and Racialized Populations" (McKenzie et al., 2016). As part of the project, the MHCC called for examples of promising practices designed to meet the mental health needs of immigrant, refugee, ethnocultural, and racialized (IRER) individuals or designed to address the adverse affects of social determinants of health; thirty-two examples were catalogued across Canada. The MHCC calls the examples "Canadian Practices of Interest" (McKenzie et al., 2016, p. 16) because they have not yet been evaluated to earn the title of good or best practices. Still, the project on the "Case for Diversity" offers access to information on services in BC, Alberta, Manitoba, Ontario, Quebec, and Nova Scotia.

The service programs include refugee and immigrant youth programming, family support programs, referral to multicultural therapy, language services, refugee health clinics, healthcare provider cultural awareness training, child and youth trauma 
services, and more. You can find the MHCC project information and links to all the "practices of interest" through The Case for Diversity - Promising Practices (MHCC, 2021).

Access to health and mental health resources produced by Immigration, Refugees and Citizenship Canada (IRCC):

- Understanding how health care works in Canada

- Newcomers to Canada: Support for Mental Health and Well-Being

- Your Mental Health and Well-Being (Video)

- Information on the Interim Federal Health Program

Learning Activity 6: Case Study - Michael

\section{Michael}

Michael is a 43-year-old mechanical engineer. He arrived in Canada seven months ago as a government-assisted refugee (GAR). Michael and his family fled their home country because of civil war. The fighting was occurring in their town. Schools had shut down, and the government department Michael worked for stopped functioning because of the violence and devastation. The group fighting that was against the government had made threats against Michael and his family, thinking he was pro-government because was working for the government. Michael, his wife, Selen, and their two children were recognized as refugees by the UNHCR.

Michael travelled to Canada a few months ahead of his family. He is fluent in English and French. Although his professional credentials have not yet been assessed, Michael has been able to find employment providing administrative support in a small engineering 
firm, and he reports being happy to be learning more about engineering projects in Canada.

His wife and two children just arrived last month. He has brought his wife, Selen, to the settlement agency so she can be enrolled in the Orientation program.

During Michael's first months in Canada, whenever he came into the agency, he was smiling and positive and seemed to have a lot of energy. He was really looking forward to having his family with him in Canada. He often talked about them.

However, when Michael comes into the agency with Selen, he looks very tired and does not seem positive at all.

\section{Case Study Questions}

Use the questions below to consider how post-migration resilience and stressors can change over time. Discuss your responses with others working through this chapter.

1. What stressors do you think Michael experienced when he arrived in Canada?

2. What sources of resilience might he have had on arrival?

3. What stressors and sources of resilience do you think Michael may have now that his family has arrived?

4. Why might Michael seem tired and less positive now than when he first arrived?

5. Do you think Michael might need formal mental health services?

6. What barriers might Michael experience in trying to access healthcare services? What characteristics about Michael might make it easier for him to access services compared to other newcomers? 
Before you began working through this chapter, you wrote down a few details about your knowledge and expectations. Now you have a chance to revisit what you wrote to see if your ideas have changed, grown, or been reinforced. As in the beginning of the chapter, feel free to answer the following questions directly or use them as a guide for reflection.

1. When you read the word "trauma," what do you understand it to mean?

2. What factors impact a person's chances of recovering from a traumatic experience?

3. What resources do you think a person needs to help them cope with a traumatic experience?

4. When you read the term "resilient," what do you understand it to mean?

5. When you read the term "mental health," what do you understand it to mean?

6. What do you hope to do with the knowledge from this chapter?

7. Whose "job" is it to help new immigrants to Canada?

Learn more about your local context. Search the internet or call local settlement service provider organizations for more information about the following:

1. Does your community have a refugee health clinic or doctors who specialize in newcomer mental and physical health?

2. Who are the local stakeholder organizations or groups that provide services to newcomers beyond the government- 
funded settlement services organizations?

- National organizations? NGOs?

- Community organizations, partnerships, or roundtables?

- Municipal programs for newcomers?

- Refugee health advocacy groups?

- Community-based interpretation services?

3. Are there any programs or organizations that advocate for newcomers in ways that may help increase newcomers' social sources of resilience? Can you find any of the following in your local community?

- LGBTQ2S+ newcomer groups

- High-skilled employment mentorship programs

- Supports for asylum seekers yet to be recognized as refugees

- Social groups for newcomers

- Organized casual language skills practice groups or programs

Image Credit

[Safety, protection] by Hurca, Pixabay licence 


\section{Conclusion}

\section{Summary}

Migration includes many stressors during all stages (pre-, during, and post-migration). Many of those stressors can be traumatic and are referred to as "migration-related trauma." People experience trauma from a very individualized perspective owing to a combination of factors, including personality, family and personal values, and cultural norms.

Forced migration is highly correlated with migration-related trauma, but forced migration is a debated concept. International and national laws currently recognize migrants forced to move because of political conflict. Those migrants are called refugees. People forced to move because of other factors, such as climate change, are not yet recognized in any international laws. Many scholars, policymakers, and forcedmigration advocates think that environmental factors should be recognized as drivers of forced migration.

Canada has refugee resettlement programs specifically structured to support the most vulnerable refugees, often those who have experienced significant migration-related trauma. There are many stakeholders involved in Canada's refugee resettlement programs. Collaboration among them can require extra coordination to prevent stakeholders themselves from creating further stressors for the newcomers they are supporting. Newcomers with migration-related trauma experiences may have significant challenges accessing mental health supports in Canada because of language barriers, location of services, or mental health professionals' level of experience with war or torture-related trauma. "Resilient" is a term used to describe migrants who appear to cope and recover from traumatic experiences. Resilience can come from personality, social networks, stable relationships, and stable living conditions. Post-migration stressors have the strongest correlation with newcomer mental health.

Summary Activity 
The following questions are designed to give you a chance to review and check how well you recall the information from this chapter.

The questions are multiple choice and true/false. Some ask you to identify the best possible answer, whereas others ask you to choose multiple possible best answers. True/false questions ask you to identify whether a statement is true or false.

When you have completed the questions, you will be able to see all your results compared to the correct responses. You can go back and redo the activity as many times as you like.

Choose all the best possible answers:

Choose whether the following statements are True or False.

圆 An interactive $\mathrm{H} 5 \mathrm{P}$ element has been excluded from this version of the text. You can view it online here:

https://openeducationalberta.ca/settlement/?p=224\#h5p-28

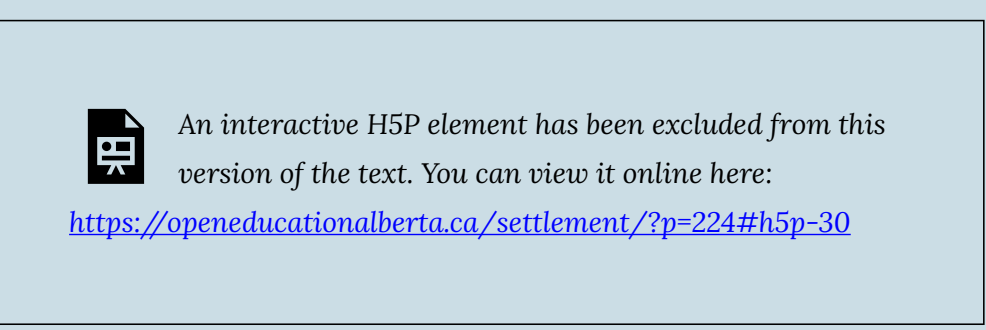




\section{Optional Readings and Resources}

Centre for Addiction and Mental Health (CAMH). (n.d.). Immigrant and refugee mental health project: A toolkit of resources. https://irmhp-psmir.camhx.ca/toolkit

International Organization for Migration (IOM). (n.d.). Migration health research portal: Home. https://migrationhealthresearch.iom.int/

Robert, A., \& Gilkinson, T. (2012). Mental health and well-being of recent immigrants in Canada: Evidence from the Longitudinal Survey of Immigrants to Canada (LSIC). Government of Canada. https://www.canada.ca/en/immigration-refugeescitizenship/corporate/reports-statistics/research/mental-health-well-beingrecent-immigrants-canada-evidence-longitudinal-survey-immigrants-canada-lsic. $\underline{\mathrm{html}}$

Schouler-Ocak, M. (Ed.) (2015). Trauma and migration: Cultural factors in the diagnosis and treatment of traumatised migrants. Springer.

Simich, L., \& Andermann, L. (Eds.) (2014). Refuge and resilience: Promoting resilience and mental health among resettled refugees and forced migrants. Springer.

Statistics Canada. (2021). Longitudinal Survey of Immigrants to Canada: A portrait of early settlement experiences. https://www150.statcan.gc.ca/n1/en/catalogue/ $\underline{89-611-X}$

Theisen-Womersley G. (2021) Trauma and migration. In Trauma and resilience among displaced populations. Springer, Cham. https://doi.org/10.1007/ 978-3-030-67712-1_2 


\section{Chapter References and Attributions}

\section{References}

Abel, G. J., Brottrager, M., Crespo Cuaresma, J., \& Muttarak, R. (2019). Climate, conflict and forced migration. Global Environmental Change, 54, 239-249. https://doi.org/ $\underline{10.1016 / \text { j.gloenvcha.2018.12.003 }}$

Australian Government, Department of Home Affairs. (2018). The Special Humanitarian

Program (SHP). https://immi.homeaffairs.gov.au/what-we-do/refugee-andhumanitarian-program/the-special-humanitarian-program

Bayar, M., \& Aral, M. M. (2019). An analysis of large-scale forced migration in Africa. International Journal of Environmental Research and Public Health, 16(21), 4210. https://doi.org/10.3390/ijerph16214210

Beiser, M. (2014). Personal and social forms of resilience: Research with Southeast Asian and Sri Lankan Tamil refugees in Canada. In L. L. A. Simich (Ed.), Refuge and resilience: Promoting resilience and mental health among resettled refugees and forced migrants (pp. 73-90).

Canadian Council for Refugees. (2010). Refugees and immigrants: A glossary. https://ccrweb.ca/en/glossary

Canadian Red Cross. (2017). One year donor update: 2016 Alberta fires. https://www.redcross.ca/crc/documents/Where-We-Work/Canada/Alberta/ AlbertaFiresInfo/AB-Fires One-Year Report en.pdf

Carlson, B. E., Cacciatore, J., \& Klimek, B. (2012). A risk and resilience perspective on unaccompanied refugee minors. Social Work, 57(3), 259-269. https://doi.org/ $\underline{10.1093 / \mathrm{sw} / \mathrm{sws} 003}$

Chadwick, K. A., \& Collins, P. A. (2015). Examining the relationship between social support availability, urban center size, and self-perceived mental health of recent immigrants to Canada: A mixed-methods analysis. Social Science \& Medicine, 128, 220-230. https://doi.org/10.1016/j.socscimed.2015.01.036

Chen, W., Hall, B. J., Ling, L., \& Renzaho, A. M. N. (2017). Pre-migration and postmigration factors associated with mental health in humanitarian migrants in Australia and the moderation effect of post-migration stressors: findings from the first wave data of the BNLA cohort study. The Lancet Psychiatry, 4(3), 218-229. https://doi.org/10.1016/s2215-0366(17)30032-9 
Conte, A., \& Migali, S. (2019). The role of conflict and organized violence in international forced migration. Demographic Research, 41, 393-424. https://doi.org/ 10.4054/DemRes.2019.41.14

DesRoches, R., Comerio, M., Eberhard, M., Mooney, W., \& Rix, G. (2011). Overview of the 2010 Haiti earthquake. https://escweb.wr.usgs.gov/share/mooney/142.pdf

Eberle, U., \& Franz, P. (n.d.). The climate factor in Nigeria's farmer-herder violence. International Crisis Group. https://nigeriaclimate.crisisgroup.org/

Faist, T. (2020). Commentary: Getting out of the climate migration ghetto: Understanding climate degradation and migration as processes of social inequalities. International Migration, 58(6), 247-253. https://doi.org/10.1111/ imig.12793

Gatt, J. M., Alexander, R., Emond, A., Foster, K., Hadfield, K., Mason-Jones, A., Reid, S., Theron, L., Ungar, M., Wouldes, T. A., \& Wu, Q. (2019). Trauma, resilience, and mental health in migrant and non-migrant youth: An international cross-sectional study across six countries. Frontiers in Psychiatry, 10, 997. https://doi.org/10.3389/ fpsyt.2019.00997

Gaynor, T. (2020, November 30). Climate change is the defining crisis of our time and it particularly impacts the displaced. UN High Commissioner for Refugees (UNHCR). https://www.unhcr.org/news/latest/2020/11/5fbf73384/climatechange-defining-crisis-time-particularly-impacts-displaced.html

Gouvernement du Québec. (2006). Program for Refugees Abroad - Collective sponsorship. https://www.immigration-quebec.gouv.qc.ca/en/immigrate-settle/ humanitarian-immigration/collective-sponsorship/index.html

Government of Alberta. (2021). 2016 wildfire reviews. https://www.alberta.ca/ 2016-wildfire-review.aspx

Government of Alberta. (2017). Psychosocial response and recovery evaluation of the RMWB wildfire 2016: final report. https://open.alberta.ca/publications/ psychosocial-response-and-recovery-evaluation-of-the-rmwb-wildfire-2016

Government of Canada. (2021a). 2020 annual report to Parliament on immigration. https://www.canada.ca/en/immigration-refugees-citizenship/corporate/ publications-manuals/annual-report-parliament-immigration-2020.html\#annex2

Government of Canada. (2021b). Interim federal health program: What is covered. https://www.canada.ca/en/immigration-refugees-citizenship/services/ refugees/help-within-canada/health-care/interim-federal-health-program/ coverage-summary.html 
Government of Canada. (2021c). Newcomers to Canada: Support for mental health and well-being. https://www.canada.ca/en/immigration-refugees-citizenship/ services/new-immigrants/new-life-canada/health-care-card/mental-health.html

Government of Canada. (2021d). Sponsorship Agreement Holders: About the program. https://www.canada.ca/en/immigration-refugees-citizenship/services/ refugees/help-outside-canada/private-sponsorship-program/blended-visaoffice-program.html

Government of Canada. (2021e). Understand how health care works in Canada. https://www.canada.ca/en/immigration-refugees-citizenship/services/newimmigrants/new-life-canada/health-care-card.html

Government of Canada. (2020a). 2019 annual report to Parliament on immigration. https://www.canada.ca/en/immigration-refugees-citizenship/corporate/ publications-manuals/annual-report-parliament-immigration-2019.html

Government of Canada. (2020b). Blended Visa Office-Referred Program: About the process. https://www.canada.ca/en/immigration-refugees-citizenship/services/ refugees/help-outside-canada/private-sponsorship-program/blended-visaoffice-program.html

Government of Canada. (2020c). Joint Assistance Program: About the process. https://www.canada.ca/en/immigration-refugees-citizenship/services/ refugees/help-outside-canada/private-sponsorship-program/joint-assistanceprogram.html

Government of Canada. (2020d). Social determinants of health and health inequalities. https://www.canada.ca/en/public-health/services/health-promotion/ population-health/what-determines-health.html

Government of Canada. (2019). Government-Assisted Refugees Program. https://www.canada.ca/en/immigration-refugees-citizenship/services/ refugees/help-outside-canada/government-assisted-refugee-program.html

Government of Canada. (2010). Government of Canada introduces special immigration measures in response to the earthquake in Haiti. https://www.canada.ca/en/news/ archive/2010/01/government-canada-introduces-special-immigration-measuresresponse-earthquake-haiti.html

Government of Canada, Immigration, Refugees and Citizenship Canada. (2014a). Country of asylum class - Conditions. https://www.canada.ca/en/immigrationrefugees-citizenship/corporate/publications-manuals/operational-bulletinsmanuals/refugee-protection/resettlement/admissibility/asylum.html

Government of Canada, Immigration, Refugees and Citizenship Canada. (2014b). 
Humanitarian and compassionate consideration. https://www.canada.ca/en/ immigration-refugees-citizenship/corporate/publications-manuals/operationalbulletins-manuals/permanent-residence/humanitarian-compassionateconsideration.html

Government of Canada, Justice Laws Website. (2019). Immigration and Refugee Protection Act (S.C. 2001, c. 27). https://laws-lois.justice.gc.ca/eng/acts/c-18.7/ page-1.html

International Association for the Study of Forced Migration (IASFM). (n.d.). Mission of the IASFM. http://www.efms.uni-bamberg.de/iasfm/mission.htm

International Climate Group. (2020, July 26). Stopping Nigeria's spiralling farmer-herder violence. Report no. 262/Africa. https://www.crisisgroup.org/ africa/west-africa/nigeria/262-stopping-nigerias-spiralling-farmer-herderviolence

Kaduuli, S. (2020, February 5). Canada has a moral obligation to accept climate migrants. Policy Options. https://policyoptions.irpp.org/magazines/ february-2020/canada-has-a-moral-obligation-to-accept-climate-migrants/

McKenzie, K. J., Agic, B, Tuck, A., \& Antwi, M. (2016). The case for diversity: Building the case to improve mental health services for immigrant, refugee, ethno-cultural and racialized populations. Report to the Mental Health Commission of Canada. https://www.mentalhealthcommission.ca/sites/default/files/2016-10/ case for diversity oct 2016 eng.pdf

McKenzie, K. J., Tuck, A., \& Agic, B. (2014). Mental healthcare policy for refugees in Canada. In L. L. A. Simich (Ed.), Refuge and resilience: Promoting resilience and mental health among resettled refugees and forced migrants (pp. 181-194). Springer.

Mehler Paperny, A. (2010, January 16). Canada to give immigration priority to Haiti earthquake survivors. https://www.theglobeandmail.com/news/politics/canadato-give-immigration-priority-to-haiti-earthquake-survivors/article4187524/

Mental Health Commission of Canada (MHCC). (2021). The case for diversity promising practices. https://www.mentalhealthcommission.ca/English/casediversity-promising-practices

Murphy, J. (2017, May 2). Fort McMurray, one year after the massive fire known as 'The Beast.' BBC News. https://www.bbc.com/news/world-us-canada-39726483

Murray, S. (2010). Environmental migrants and Canada's refugee policy. Refuge, 27(1). https://doi.org/10.25071/1920-7336.34351

Nickerson, A., Bryant, R. A., Schnyder, U., Schick, M., Meuller, J., \& Morina, N. (2014). 
Emotion dysregulation mediates the relationship between trauma exposure, postmigration living difficulties and psychological outcomes in traumatized refugees. Journal of Affective Disorders, 173, 185-192. http://dx.doi.org/10.1016/ j.jad.2014.10.043

NPR. (2020, January 12). Haiti in ruins: A look back at the 2010 earthquake. The Picture Show. https://www.npr.org/sections/pictureshow/2020/01/12/794939899/haitiin-ruins-a-look-back-at-the-2010-earthquake

Ozcurumez, S., Wylie, L., Bigot, G., \& Dauth, R. (2012). Barriers in access to care. In Migrants and health (pp. 105-138). Routledge.

Pedersen, D. (2015). Rethinking trauma as a global challenge. In M. Schouler-Ocak (Ed.), Trauma and migration: Cultural factors in the diagnosis and treatment of traumatised immigrants. Springer.

Refugee Sponsorship Training Program. (2021). The Private Sponsorship of Refugees (PSR) Program. https://www.rstp.ca/en/refugee-sponsorship/the-privatesponsorship-of-refugees-program/

Schouler-Ocak, M. (Ed.). (2015). Trauma and migration: Cultural factors in the diagnosis and treatment of traumatised immigrants. Springer.

Sheath, D., Flahault, A., Seybold, J., \& Saso, L. (2020). Diverse and complex challenges to migrant and refugee mental health: Reflections of the M8 Alliance Expert Group on Migrant Health. International Journal of Environmental Research and Public Health, 17(10), 3530. https://doi.org/10.3390/ijerph17103530

Statistics Canada. (2010). Canada's ethnocultural mosaic, 2006 Census: Definitions. https://www12.statcan.gc.ca/census-recensement/2006/as-sa/97-562/noteeng.cfm\#: :text=Recent\%20immigrants\%20(also\%20known\%20as,to\%20a\%20give n\%20census\%20year

Steel, J. L., Dunlavy, A. C., Harding, C. E., \& Theorell, T. (2017). The psychological consequences of pre-emigration trauma and post-migration stress in refugees and immigrants from Africa. Journal of Immigrant Minority Health, 19, 523-532. https://doi.org/10.1007/s10903-016-0478-z

Tozer, M, Khawaja, N. G., \& Schweitzer, R. (2018). Protective factors contributing to wellbeing among refugee youth in Australia. Journal of Psychologists and Counsellors in Schools, 28(1), 66-83. https://www.cambridge.org/core/journals/journal-ofpsychologists-and-counsellors-in-schools/article/protective-factorscontributing-to-wellbeing-among-refugee-youth-in-australia/ BAC767FC12EE6E30F0BD87E35E894C40\# 
UN High Commissioner for Refugees (UNHCR). (2021a). Asylum seekers. https://www.unhcr.org/asylum-seekers.html

UN High Commissioner for Refugees (UNHCR). (2021b). Information on UNHCR resettlement. https://www.unhcr.org/information-on-unhcr-resettlement.html

UN High Commissioner for Refugees (UNHCR). (2021c). Nigeria emergency. https://www.unhcr.org/nigeria-emergency.html

UN High Commissioner for Refugees (UNHCR). (2020). Global report 2019. https://reporting.unhcr.org/sites/default/files/gr2019/pdf/ GR2019_English_Full_lowres.pdf\#_ga=2.154391672.1711354680.1630771316-1866916 $\underline{503.1630771316}$

UN High Commissioner for Refugees (UNHCR). (2019). Global trends: Forced displacement in 2018. https://www.unhcr.org/5d08d7ee7.pdf

UN High Commissioner for Refugees (UNHCR). (2006). UNHCR master glossary of terms, Rev. 1. https://www.refworld.org/docid/42ce7d444.html

United Nations General Assembly. (1951). Convention relating to the status of refugees. United Nations Treaty Series. Vol. 189. https://www.refworld.org/docid/ $\underline{\text { 3be01b964.html }}$

World Health Organization (WHO). (2014). Social determinants of mental health. https://www.who.int/publications/i/item/9789241506809

Wylie, L., Corrado, A. M., Edwards, N., Benlamri, M., \& Murcia Monroy, D. E. (2020). Reframing resilience: Strengthening continuity of patient care to improve the mental health of immigrants and refugees. International Journal of Mental Health Nursing, 29(1), 69-79. https://doi.org/10.1111/inm.12650

Wylie, L., Van Meyel, R., Harder, H., Sukhera, J., Luc, C., Ganjavi, H., Elfakhani, M., \& Wardrop, N. (2018). Assessing trauma in a transcultural context: challenges in mental health care with immigrants and refugees. Public Health Reviews, 39, 22. https://doi.org/10.1186/s40985-018-0102-y

Yaylaci, F. T. (2018). Trauma and resilient functioning among Syrian refugee children. Developmental Psychopathology, $\quad 30(5), \quad$ 1923-1936. https://pubmed.ncbi.nlm.nih.gov/30295224/ 


\section{Media Attributions}

Citizenship and Immigration Canada. (220, October 28). Your mental health and wellbeing [Video]. YouTube. https://www.youtube.com/watch?v=uFF112B7Y\&ab channel=CitizenshipandImmigrationCanada\%2FCitoyennet\%C3\%A9etIm $\underline{\text { migrationCanada }}$ 



\section{CHAPTER 4: FAMILY DYNAMICS - WORKING WITH SENIORS}





\title{
Introduction
}

\author{
RENNAIS GAYLE
}

Settlement experiences among older immigrants who migrate late in life vary based on immigration class, traditions in the country of origin, pre-existing supports, and socioeconomic outlook. Sheets \& Gallagher (2013) report that "Migration accounts for about two thirds of the total population growth in Canada. Ethnic diversity is increasing, and by 2031 , approximately $28 \%$ of the population will be foreign born" (p. 2). Before delving into this chapter, it is important to explore the definition of a senior and decolonizing our understanding of age and social status (Kennedy, McGowan, \& El-Hussein, 2020). Becoming a senior in Canada is generally seen as a life stage that is based on a retirement system; that is, when one reaches 65 years of age, they access a pension plan (Sheets \& Gallagher, 2012, pp. 3-4).

In the Indigenous Canadian context, an Elder is someone who is able to offer a high degree of understanding of First Nations, Métis, or Inuit history, traditional teachings, ceremonies, and healing practices. Elders are the keepers of traditional knowledge, and their social position is not necessarily based on being a specific age. Kennedy, McGowan, and El-Hussein (2020) share that Indigenous knowledge is an opportunity to decolonize western perspectives of who is considered an Elder (p. 2). Nyamweru and Chidongo (2018) use the terms Elders and Councils of Elders to describe categories of Kenyan Elders who have positive roles in media and among younger people, as well as influence in society (p. 242). Elders from Nyamweru and Chidongo's (2018) research are immediate family members who provide moral and extended parental guidance, whereas a Community of Elders (CoE) plays an important community role or is made up of Knowledge Keepers for important rites of passage, particularly in specific ethnic clans (p. 243).

In this chapter, an Elder is defined as someone who is the keeper of cultural traditions and may have gone through a life cycle to retirement. Elders are regarded as a point of cultural or traditional reference among immediate family and/or their own ethnocultural community. This definition will be used to contextualize the settlement experiences of older immigrants living in Canada. The images in Figure 1 provide a visual representation of the core discussion areas about immigrant seniors in Canada.

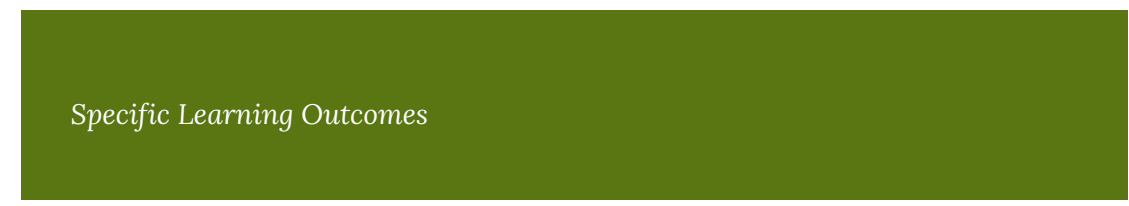


By the end of this chapter, you should be able to

1. Examine various settlement and resettlement experiences of immigrant seniors to build an understanding of client needs

2. Apply theories in communicating with immigrant seniors

3. Reflect on biases, microaggressions, and stereotyping, and their impacts on immigrant seniors

4. Plan for action to solve problems using settlement case studies 

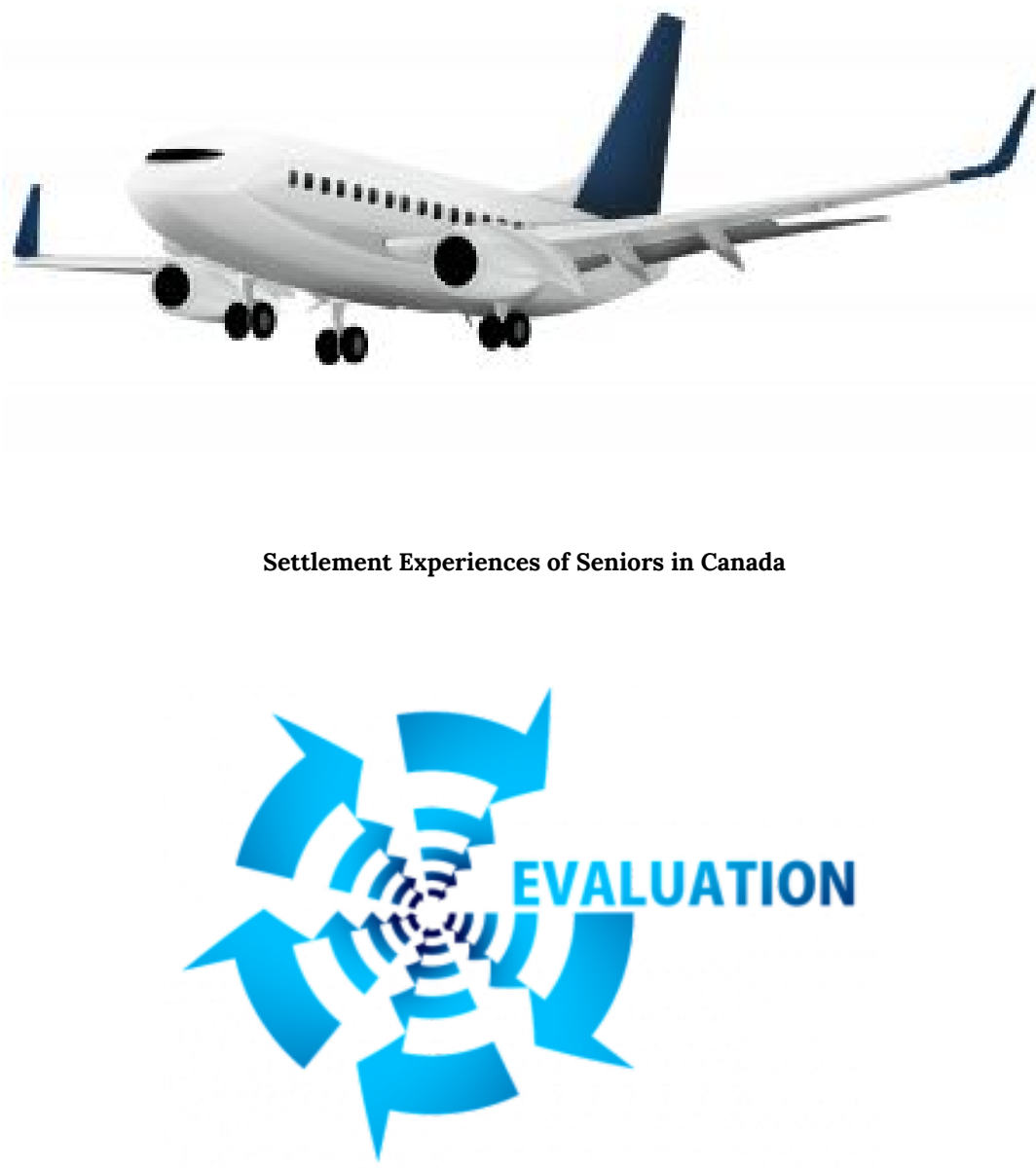

Evaluating Client Needs

Figure 1: Chapter topics - These figures represent the topics discussed in this chapter. 


\section{Key Terms}

Image Credits (images listed in order of appearance)

AirPlane by xfaststyle, CC BY 3.0 Unported licence

CommunicationProcessModel by Amazonnews, $\mathrm{CC} 01.0$ Public Domain licence

Evaluation by geralt, Pixabay licence

Problem solving by geralt, Pixabay licence

194 | Introduction 


\begin{tabular}{|c|c|}
\hline Acculturation & To blend into or assimilate into a dominant and diffe \\
\hline Aging in place & The process of aging in a familiar home or country \\
\hline Aging out of place & $\begin{array}{l}\text { The process of aging that takes place outside one's } \\
\text { physical, and financial stress that otherwise would I }\end{array}$ \\
\hline Communication Accommodation Theory & Behavioural changes that people make in relation to \\
\hline Continuity Theory & $\begin{array}{l}\text { The natural occurrences of aging when older adults } \\
\text { the earlier parts of their lives }\end{array}$ \\
\hline Exchange Theory & Aging occurrences that take place when one ages or \\
\hline Healthy aging & The normal cycle of aging based on social and physi \\
\hline Life Course Theory & A theory on the four stages of life, which include ch \\
\hline Local immigrant partnership & $\begin{array}{l}\text { A partnership designed to plan settlement for newc } \\
\text { and participate }\end{array}$ \\
\hline Microaggression & $\begin{array}{l}\text { A verbal statement or action that is hostile, derogat } \\
\text { and are against marginalized groups of people }\end{array}$ \\
\hline$\underline{\text { Multiculturalism }}$ & $\begin{array}{l}\text { The co-existence and celebration of many diverse } c \\
\text { language }\end{array}$ \\
\hline Stereotype & An oversimplified assumption or understanding abo \\
\hline Welcoming community & $\begin{array}{l}\text { A community in which citizens and members of the } \\
\text { feel a sense of belonging }\end{array}$ \\
\hline
\end{tabular}




\section{Settlement Experiences of Seniors Coming to Canada}

More than $90 \%$ of recent immigrants to Canada reside in metropolitan areas (Dam \& Wayland, 2016, p. 362). The top four provinces for immigration are Ontario, British Columbia, Quebec, and Alberta (Guo \& Guo, 2016, p. 46). The positive impact of Canada's immigration program continues to build Canada's economy and cultural diversity. Urban versus rural resettlement has its own benefits and challenges. For example, the benefits of living in an urban centre include access to traditional foods in local ethnic grocers, religious places of worship, and ethnocultural community activities and celebrations. In contrast, some immigrant seniors may prefer a rural setting, particularly if they were used to living in a remote farming community. However, moving from an urban centre to a rural community may lead to feelings of isolation from one's culture, community, language, and other identity-forming factors.

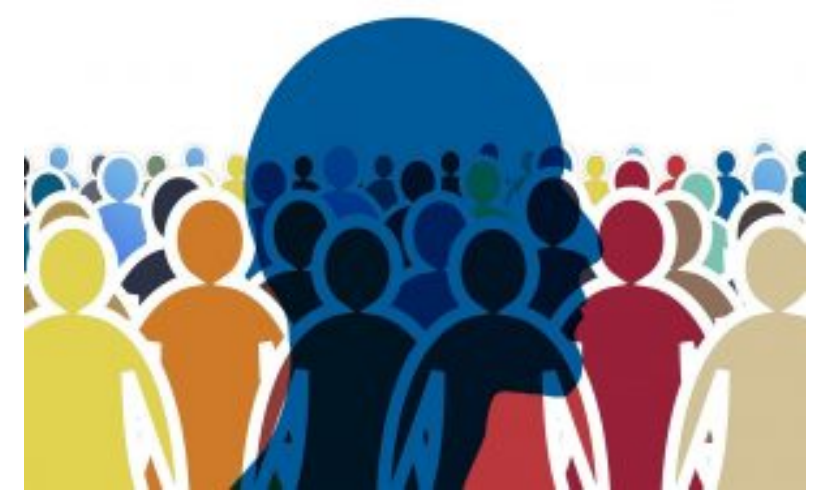

In 2016, immigrant seniors represented 31\% of all seniors in Canada (Kei, Seidel, Ma, \& Houshmand, 2016, p. 1). Most were sponsored under the Parent or Grandparent Program. According to Mandell, Hemphill, Borras, and Phonepraseuth (2019), immigration from Africa was the highest in 2016, with $13.4 \%$ of working-class immigrants hailing from Nigeria, Morocco, Cameroon, and Algeria (p. 3). Refugee immigration was second highest from Zimbabwe and Sudan (Stewart et al., 2017, p. 234). Furthermore, in Guo and Guo's 2016 study, Calgary was the city with the fourth highest number of recent economic-class immigrants, most coming from the Philippines, India, China, Vietnam, Pakistan, and South Korea (p. 53). In summary, 
immigrant seniors migrate from various countries of origin and reside across various parts of Canada.

As immigrant seniors arrive in Canadian cities, the role of local immigration partnerships (LIPs) have become increasingly important (Government of Canada, 2013). An LIP is a federally funded mechanism that partners with local stakeholders to support newcomer integration into employment, schools, health centres, and social services. Stakeholders include employers, school boards, health centres, professional associations, ethnocultural organizations, faith-based organizations, and not-forprofit organizations. LIPs strengthen Canada's Multiculturalism Act (Government of Canada, 1988), encouraging the freedom of expression of one's diverse culture, which supports the economic, social, and cultural fabric Canada (Guo \& Guo, 2016, p. 48). Furthermore, members of LIPs, such as settlement organizations, provide counselling, career supports, employment training, citizenship classes, and other services (Guo \& Guo, 2016, p. 50). Multicultural or ethnocultural organizations provide community development that supports cultural awareness, advocacy, and the celebration of diversity (Guo \& Guo, 2016, pp. 50-51).

Many of the case studies or situations described in this chapter take into account migration stories and the family and cultural dynamics of immigrant seniors. Note that case studies and situations are based on real-life scenarios that have been adapted to create fictitious scenarios and events. Now we will contextualize immigration and the impacts of settlement on seniors in Canada.

Many elderly immigrants who migrate to Canada do not have the skills to navigate cultural dynamics, so personal, psychological, and social supports are necessary to reduce stress among elderly immigrants related to migration. These supports include relational, structural, functional, and constitutional supports for appropriate integration into Canadian systems and cities (Noh, Kim, \& Noh, 2018, p. 214). "Relational supports" refers to personal connections such as extracurricular activities and interests and building friendships. "Structural supports" refers to an understanding of and ability to access services that may be relevant to the lived experiences of immigrant seniors. This may include access to affordable transportation, health and wellness information, and access to services. In contrast, "functional support" includes having the practical life skills to live in Canada, and "constitutional supports" may include an understanding of basic Canadian human rights and local laws that protect these rights in an everyday setting.

Late-life migration among elderly immigrant working-class refugees and retired newcomers presents complex resettlement challenges. In one study, elderly Korean Canadians were found to have adjustment challenges specific to language barriers, personal and social networks, access to health and social services, and coping with family relationships (Kwak \& Lai, 2018, pp. 220-224). Children were the primary resource for help and the type of help was based on gender (Kwak \& Lai, 2018, pp. 
220-221). For example, working males were expected to be the breadwinners and bear familial financial responsibilities, including that of financial elder support, whereas female working children were expected to provide emotional support to elders (Kwak \& Lai, 2018, p. 221). Transportation and curricular activities provided opportunities to combat isolation (Kwak \& Lai, 2018, p. 227).

In contrast, refugee families faced more challenges obtaining social supports, particularly because many were unable to migrate with traditional elders and became elders themselves at earlier ages to act as role models for young, orphaned youth in the extended family. Stewart et al. (2017) shares in one study of Zimbabwean and Sudanese refugee migration that "an expectant mother lives with her mother until she gives birth. The mother and sisters provide support needed, including practical support. However, this traditional support was unavailable to new mothers in Canada" (p. 241). Also, affordable childcare was the most challenging among refugees in this study because the extended family of elders was unavailable, leading to higher rates of postpartum depression (p. 246). As such, for many refugees, an elder may be a significant individual in the ethnocultural community and may take on the role of a mentor or older elderly figure. Also, peer support groups, information support, culturally sensitive language support, and cultural recreational support provided intervention mechanisms among refugees, leading to better chances of integration and resettlement. We will now discuss concepts of what it means to age in a resettlement context.

"Healthy aging" refers to the normal cycle of aging based on physical changes and the autonomy one becomes accustomed to (Sadarangani \& Jun, 2015, p. 110). "Aging in place" refers to having a familiar home, supporting environment, and community (p. 110). For many elders, late-life migration results in aging out of place, which leads to increased social, psychological, physical, and financial stress that otherwise would not occur if the person had remained in their country of origin. For example, elderly family members may be required to help with full-time grandparenting while learning to integrate into Canadian society, learn a new language, and build social connections. This may cause resentment, fear, or anger towards adult children because elders become more dependent on the younger generation for emotional and financial support. It is also important to note that Straiton, Ledesma, and Donnelly (2018) found that half of the immigrants around the world were women and as such faced greater social disadvantages, poorer socio-economic conditions, abuse, and social isolation (p. 2). Simich, Hamilton, and Baya (2006) found that health challenges experienced by Sudanese elders were caused by "work-related frustrations and stresses, and family separation" (p. 429). Este and Tachble (2009) shared an anecdote from one Sudanese father, who reported, "In Canada as an immigrant I do not have time for the family because all the time I just work, work, sleep, and there is no time that you can enjoy, even with your family" (p. 462).

The settlement experiences described in this section vary depending on immigration 
class and familial supports. However, there are recurring themes along the lines of challenges with social supports, isolation, dependency, loss of autonomy, and health and wellness challenges among immigrant seniors who have settled in Canada.

Learning Activity 1: Situation 1 - Healthy Aging, Aging in Place, and Aging Out of Place

\section{Zamir}

Zamir immigrated with his son and daughter-in-law to escape civil war. He is a medically trained doctor and was about to retire before bombings began in his home country. Zamir is well respected in his community in Calgary and finds solace in attending his local mosque and volunteering in his ethnocultural community. Zamir wants to impart cultural and traditional norms to his adult children. His son and daughter-in-law are expecting their first child this year.

\section{Reflection Questions}

1. What is your initial reaction?

2. How do you think Zamir is doing? Why?

3. What aging out of place challenges do you think Zamir may be facing? Why or why not?

4. What are some healthy aging and aging in place activities that Zamir could have had in his home country had it not been for civil war? 


\section{INSTRUCTOR NOTE}

This activity can be done in pairs or small group. This activity allows learners to digest and consider the information provided about settlement, resettlement, aging-in-place, out-of-place, and healthy aging.

\section{Image Credit}

[Social anxiety] by geralt, Pixabay licence 


\section{Theories of Late-Life Migration and Communication Accommodation Theory}

When working with immigrant seniors, it is important for practitioners to have not only an understanding of settlement challenges, but also to know how to approach communication with elders, particularly from cross-cultural and intercultural frameworks. Refer to "Chapter 5: Intercultural Competence and Communication" for more information. The Gerontological Society of America (GSA) (2012) notes several recommendations for communicating with adults to improve interactions (p. 1). We will examine a few case studies based on the GSA's evidence-based approach to communicating with older adults. It is important to note that language and intelligence does not decline as elders age; knowledge remains stable (Gerontological Society of America, 2012, p. 4). However, hearing loss is the third most common condition among people who are 65 to 75 years of age, followed by vision loss, which can limit the ability to drive at night, and a reduction in the speed and process of language (pp. 4-5).

The global aging population is expected to increase by $21.1 \%$ by 2050 (Likupe, Baxter, \& Jogi, 2018, p. 180). This can be attributed to better health care that may extend the life cycle. Sadarangani and Jun (2015) examine the impacts of late-life migration on newly arrived elderly immigrants using three theories, Life Course Theory (Clausen, 1986), Continuity Theory (Atchley, 1989), and Exchange Theory (Pyke, 1999). These theories have been summarized in Table 1. Models of Late-Life Migration and can also be applied to working and communicating with immigrant seniors (Sadarangani \& Jun, 2015, pp. 115-117). Life Course Theory surmises that immigrant seniors emigrate late in life because of historical, social, and political factors of that time. This could include economic crises or war. On the other hand, Continuity Theory is embedded in the idea that an immigrant senior who stayed behind in their country of origin would be worse off psychologically because their family bond with the younger generation would be lost, so migration is a better option. Finally, Exchange Theory evaluates the cost versus benefits of a senior migrating or remaining in their country of origin. For example, an immigrant senior may be concerned about who would take care of them as they age. Table 1. Models of Late-Life Migration summarizes the assumptions and impacts of late-life migration on the life of immigrant seniors.

Table 1. Models of late-life migration 
Life Course Theory

(Clausen, 1986)

Life is shaped by history.

Decisions are based on individual choice.

Social relationships are integral to one's life.

Transition is based on physical and social time of life (p. 115).

Continuity Theory

(Atchley, 1989)
Builds on Life Course Theory.

Life is not predictable in terms of one's environment as one se The focus is on preserving familiar structures such as culture
Exchange Theory

(Pyke, 1999)
Members of the household with the most resources control re dynamics.

Note: This table summarizes the various theories that impact the late-life migration to Canada of immigrant seniors.

\section{Communication Accommodation Theory}

On one hand, elder immigrant newcomers may see themselves as the knowledge keepers and preservers of cultural norms and heritage, but at times, they may feel frustrated, angry, or resentful that their traditional norms of power and independence may become weakened once they migrate to Canada. Communication is the best tool for supporting elderly newcomers because language barriers in communication can result in poor health care (Likupe, Baxter, \& Jogi, 2018, p. 181). This is where stereotyping occurs among settlement practitioners and health, public or social service workers when dealing with elderly newcomers, and microaggressions begin to expose the assumptions of service providers. Note, for the purposes of this chapter, a microaggression is defined as a verbal statement or action that is hostile, derogatory, or negative towards someone. Microaggressions can be subtle, indirect, or unintentional, and occur against marginalized groups of people.

One framework to consider in providing ethical, effective, and respectful 
communication is Communication Accommodation Theory, otherwise known as CAT (Momand \& Dubrowski, 2020, p. 3.). In this theory, service providers reflect on the social differences in communicative behaviour using two assumptions. First, behaviour changes based on the communicator and the recipient of the communication, and second, perception is directly correlated to how well the communicator and recipient are attuned to the conversation (p. 3). The following convergence method is used to provide effective communication between practitioner and elderly clients:

1. Speak clearly.

2. Give the client time to ask questions.

3. Ask one question at a time and speak slowly when doing So.

The divergence approach happens when practitioners speak too quickly, provide too much information at one time, and do not give the receiver (the client) time to respond. Look for non-verbal cues from the receiver such as disapproval, confusion, or head shaking "no"-all signs that the receiver is confused, uncomfortable, or not understanding the message. When considering convergence, use CAT, which includes the following:

1. Nod

2. Be empathetic

3. To build trust, look for things that they like in the room or space if in the individual's home

4. Use culturally appropriate eye contact for men and women (based on social norms)

5. Use an interpreter, if applicable

The convergent approach is more appropriate to use over the divergent approach because it builds rapport between the settlement practitioner and the client. In contrast, the divergent approach may be seen by the client as dismissive and 
confusing, whereas the convergent approach demonstrates respect and active listening.

Learning Activity 2: Situation 2 - Improving Verbal Communication

\section{Elisabeth}

Elisabeth is a case worker who is meeting with Eyerusalem for a follow-up appointment. Elisabeth tends to play soft music just before she meets her clients and keeps a whiteboard and markers out in case she needs to communicate using visual imagery. Eyerusalem has been living in Lethbridge for the past three years. Lately, she has begun to feel isolated. There are not many individuals living in the city from her home country, and her children are always travelling out of town for work. She loves her three grandchildren, ages 12,9 , and 6 , but she longs to spend time with her peers. Eyerusalem does not drive and speaks a moderate level of English. Her hearing has started to deteriorate, and she was given a hearing aid. She does not like to wear the aid. Eyerusalem is excited to be able to get out of the house today to meet with Elisabeth, but she is cautious about what she shares because she does not want to be judged for her feelings of loneliness. To prepare for the meeting, Elisabeth reviews her notes from Eyerusalem's last visit. She remembers that Eyerusalem was given a hearing aid and seemed saddened when she had to end the appointment. She also recognizes that Eyerusalem is taking some English classes to improve her communication. 


\section{Reflection Questions}

1. What is your initial reaction?

2. What assumptions could you make about Eyerusalem's latelife migration? How can each of the three theories inform the settlement practitioner about Eyerusalem's late-life migration experience?

3. How can Elisabeth prepare for today's visit?

An interactive H5P element has been excluded from this version of the text. You can view it online here:

https://openeducationalberta.ca/settlement/?p=230\#h5p-31

\section{INSTRUCTOR NOTE}

Although this activity can work well in an in-person think-pairshare format, it could also work well as an online discussion forum topic. 


\section{Evaluating Client Need}

One employment function of a settlement practitioner is evaluating client need. Likupe, Baxter, and Jogi (2018) report in their study on perceptions of elder immigrant clients and care workers that older immigrants are often stereotyped as having physical deficits, particularly clients from other cultures (p. 186). There is a lack of understanding of elderly newcomers from different cultural and ethnic backgrounds (p. 184). For example, elderly immigrant seniors want to be respected and want to maintain their dignity, for example, by maintaining personal space, particularly when service providers such as healthcare professionals approach them without giving a warning or explanation as to why. Furthermore, elderly immigrants from some cultures have indicated that they preferred that workers address them by their titles and not by their first names (p. 184). Also, multi-tasking while speaking with an elderly person shows a lack of care or interest and may be perceived as being disrespectful. Stopping to give time and space to the speaker improves trust. Additionally, King-Shier, Lau, Fung, LeBlanc, and Johal (2018) report in their clinical study that Asian and Chinese patients in Calgary identified a need for more language-specific clarity in access of information, as well as a need for more cultural sensitivity by healthcare providers, specifically including family members in healthcare discussions (pp. 1519-1527). Effective communication must be "jargon-free and language-specific" (p. 1527). Service providers should consider the attributes of individual clients rather than focusing on differences. These attributes include the client's immigration experience, number of years in Canada, language ability, education level, and community supports.

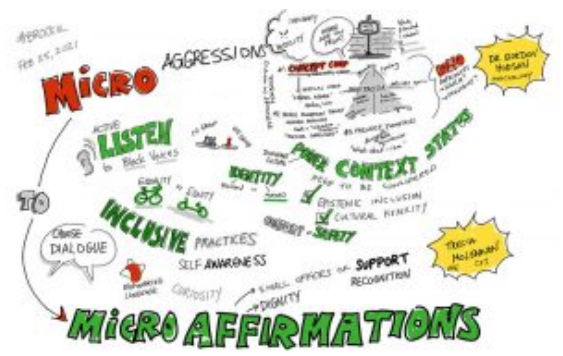

Evaluating client need also requires reflection from the settlement practitioner. The settlement practitioner should spend time reflecting on their own perceptions and attitudes when it comes to ethnicity, gender, and age. There are everyday microaggressions that may be unconsciously committed in conversations between a client and a settlement practitioner. Microaggressions are everyday actions, statements, or behaviours that have become normalized that are offensive, discriminatory, or racist and are perpetuated against a minority group through language, actions, or behaviours by a dominant group. Because there are multiple intersections when discussing diversity, such as immigration class, age, gender, race, language, and socioeconomic status, it is important to evaluate self-assumptions about a person or group of people to enact ethical communicative practices and to demonstrate strong 
professional codes of conduct. Microaggressions related to age may include questions or comments made to an older person such as the following:

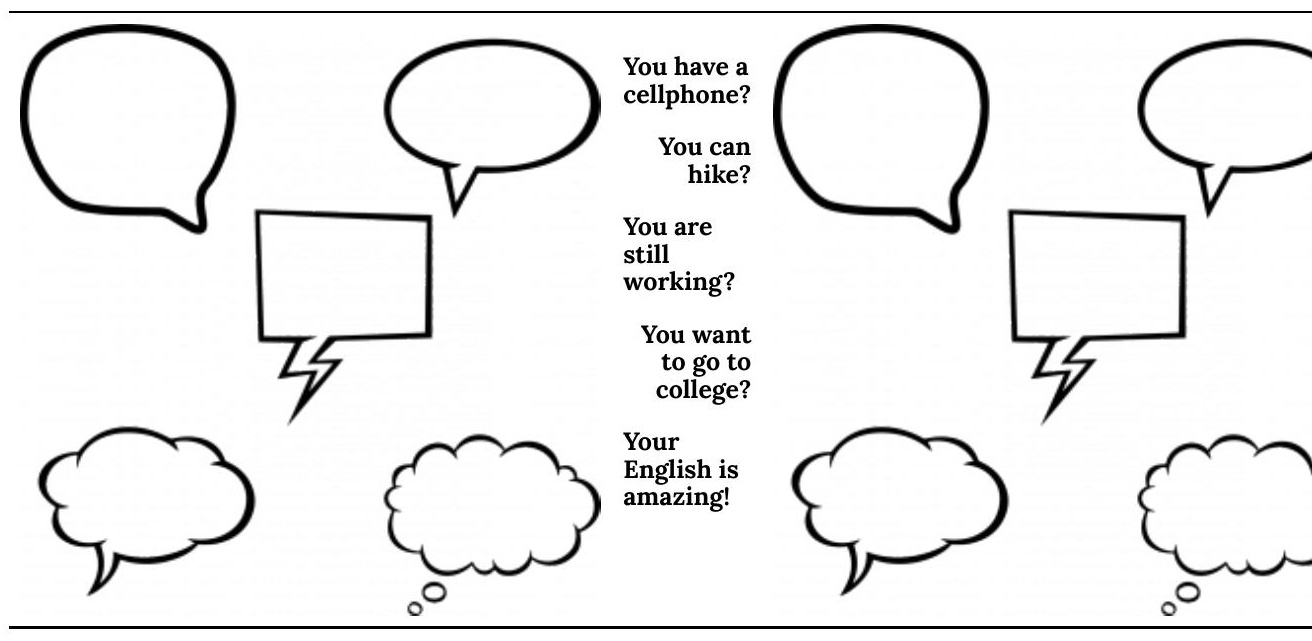

To avoid microaggressions, the settlement practitioner should reflect on their own attitudes, assumptions, and expectations. Secondly, the settlement practitioner should look for client reactions that show discomfort, uneasiness, or surprise, and consider whether a comment or action could have been interpreted as a microaggression. Thirdly, the settlement practitioner should not expect immigrant seniors to be experts in settlement topics nor expect them to resolve microaggressive behaviour perpetuated by a practitioner. Fourthly, in the event that an immigrant senior speaks about an interaction or comment that was uncomfortable during a client-settlement practitioner meeting, take the time to listen intently. Do not provide an explanation about why the action or statement was committed because it invalidates the individual's experience. Finally, thank the individual for pointing out the action or statement and explain how the issue will be addressed in future interactions in the settlement office. As part of decolonization and reconciling difficult histories around ethnicity and gender, it is especially important for settlement practitioners to be aware of their own assumptions and biases.

Learning Activity 3: Situation 3 - Personal Introspection on Stereotypes 


\section{Wayne}

Wayne is a settlement practitioner who is meeting Wei for the first time. They have a one-hour session planned to identify services that Wei may require. Wei in arrived in Calgary approximately three weeks ago. She lives in an extended family household that includes her oldest son, his wife, and two daughters. Wei is a widow and has begun making friends at a local fitness park. Wei was a dentist in China prior to her arrival in Canada and lived an active lifestyle. She studied at all-English schools from primary to post-secondary. Prior to arriving in Canada, Wei injured her leg in a boating accident; the leg never healed well and has left her needing to walk with the aid of a cane. Next month, Wei will celebrate her 70th birthday and is looking forward to going to an outdoor park with her family and newfound friends. Wei is interested in mentoring young people in dentistry and is curious about volunteer opportunities in this area. When Wayne meets Wei for the first time, he notices that Wei has a slight limp. Wayne begins to wonder if he should have had a translator included in the meeting. Wayne begins to make a call to see if any translators are available.

\section{Reflection Questions}

1. What are your preliminary assumptions about the situation?

2. What non-verbal and verbal communication is being presented to the client?

3. What should Wayne do? 
An interactive H5P element has been excluded from this version of the text. You can view it online here:

https://openeducationalberta.ca/settlement/?p=232\#h5p-32

\section{INSTRUCTOR NOTE}

This activity can be done in pairs or small group. If utilized in the OER, learners may choose to reflect only, then check responses under What You Should Do as Practice.

\section{Wayne}

Wayne has already made a few errors in his initial interaction with Wei and has corrected himself by asking a few simple interactive questions. However, in Wayne's questioning, he uses a "sing-song" or "baby" type of tone with the client and refers to her as "Dear," asking "Can I get you anything, dear?" There is a 35-year age difference between Wei and Wayne. 


\section{Reflection Questions}

1. How do you think Wei is feeling?

2. What should Wayne do?

\footnotetext{
An interactive H5P element has been excluded from this version of the text. You can view it online here:
}

https://openeducationalberta.ca/settlement/?p=232\#h5p-33

\section{INSTRUCTOR NOTE}

This activity can be done in pairs or small group. If utilized in the OER, learners may choose to reflect only, then check responses under What You Should Do as Practice.

Image Credits (images listed in order of appearance)

Microaggression by Giulia Forsythe, CC BY 4.0 International licence

Speech bubbles by 7089643 , Pixabay licence 


\section{Elder Abuse}

\section{Elder Abuse and Neglect}

Elder abuse and neglect takes place within the households of seniors of Canada (Statistics Canada, 2003, p. 28). This occurs between the older adult and the person they rely on for financial, emotional, or physical support (p. 28). Podnieks (1993) found that financial abuse was the most commonly reported form of elder abuse, followed by verbal and physical abuse, then neglect. Elder abuse affects the quality of life of non-migrant and immigrant elders in Canada, resulting in low self-esteem, injury, loss of autonomy, depression, and social isolation (Podnieks, 1993; Choi \& Mayer, 2000; McDonald \& Collins, 2000; Spencer, 2000; Lachs et al., 2002; Dong, 2005). Perpetrators of elder abuse may have challenges with depression, substance abuse, and finances (McDonald \& Collins, 2000; Podnieks, 2008; McDonald, 2011). Older adults are most often abused by an intimate partner, adult child or child-inlaw or other family member (Lithwick et al., 1999; Brozowski and Hall, 2004; Guruge et al., 2010; McDonald, 2011). As a settlement practitioner, cultural sensitivity can be complex. Furthermore, research in this area is limited. The next section will explore some opportunities for settlement practitioners to build understanding and provides strategies for addressing elder abuse among older immigrants. It focuses on sample case studies among Chinese elders and their experiences with elder abuse.

Yan (2015) reports in her study that "elderly persons subjected to abuse had a greater mortality risk than their intact counterparts" (p. 2684). Yan (2015) also explains that in Chinese culture, there is an emphasis on filial piety in that adult children are responsible for the care and financial support of and obedience to their parents (p. 2684). However, elder abuse has been noted by Yan as an increasing issue in Chinese ethnocultural communities, specifically perpetrated by family caregivers (p. 2684). Zhang's (2019) research in elder abuse and neglect (EAN) argues that migration and ageing processes, both of which engender cultural and contextual changes, shape and reshape views of EAN (Zhang, 2019, p. 341). Lai (2011) supports this argument in earlier research across seven Canadian cities, indicating that EAN suffered by Chinese immigrants is based on perceptions of elders being yelled at, ridiculed, or treated impolitely (Zhang, 2019, p. 343). In one case, Zhang (2019) reported that a daughter-in-law pushed her 70-year-old mother-in-law, who subsequently sustained a fracture and had to be hospitalized (p. 347). The mother-in-law reported that the daughter-in-law was rude and gave her the cold shoulder (p. 347). In other instances, respondents in the study reported feeling emotionally ridiculed because they had limited English skills and felt a loss of autonomy because their responsibilities were 
limited to child care and chores (p. 348). Many of the respondents indicated that they were professionals in their home countries and felt that their adult children looked down on them for having limited English skills (p. 348), which is a form of emotional abuse.

Additional challenges around perceived financial abuse were also examined. It was reported in Zhang's (2019) study that many Chinese immigrants would leave the management and decisions about finances to their children, citing that they felt they "lacked language skills and familiarity with Canadian financial systems" (p. 349). Many reported an expectation that they would be treated well by their adult children. After all, they had sold their properties in China and provided their life savings to their adult children (p. 349). Problems reported included children refusing to give money to parents when requested. When older immigrants considered remarriage in cases of divorce or widowing, older children would intervene, which was a violation of the rights of an older person in Canada (p. 350). Finally, older immigrants in the study reported neglect, giving examples of being left to live alone with limited understanding of Canadian systems or to live independently without substantial income and little to no contact with older children or grandchildren (p. 351).

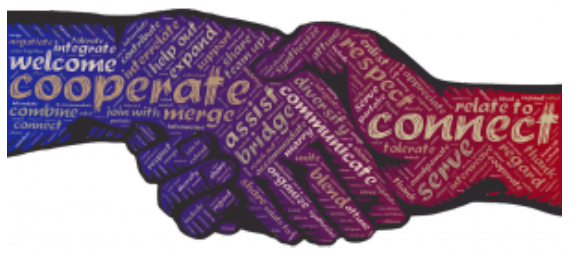

What are some ways to provide supports to older immigrants from a culturally sensitive perspective? It is important to note that any form of professional counselling must be conducted by a certified practitioner or clinician, particularly in the area of mental health counselling. These suggestions are a summary of findings from researchers in the field of elder abuse and should be used as guidelines for case management and forwarded where applicable to a licensed counsellor or psychotherapist. Thus, when working with elderly immigrants, listen empathetically. This means making eye contact, not interrupting the conversation, pausing where necessary, and repeating what you heard to clarify statements. Second, ask about available social supports. Take notes at this point. Third, ask questions starting with What would happen if? When [the care provider or support system] is [blank] what happens? Once you have jotted down notes, repeat what was said and ask if there is anything else that needs to be added. Thank the client for their willingness to share their experiences because it is typically uncommon for elderly immigrants to speak ill of a family or loved one in their community. Provide a list of resources to build social supports where possible. This could include free English-language classes, weekly walking clubs, or other community activities that may be of interest to the client. Last, ask the client if it would be okay if you met again and kept talking. Ask if it would be okay to provide more supports, which could include a counsellor and may be 
a difficult subject to approach because of the stigma associated with mental health in many cultures.

The following suggestions may support settlement practitioners in approaching the idea of counselling with an immigrant senior:

1. Involve community partnerships between settlement practitioners and immigrant groups. "Culturally sensitive community mental health education programs empower minority newcomer communities and groups about their health, especially mental health" (Thomson, Chaze, George, \& Guruge, 2015, p. 1900).

2. Provide early intervention, particularly with the support of specialized psychiatric supports (p. 1900).

3. Offer resources for language training with Englishlanguage classes that provide information and discussion on health services, processes, and access for newcomers (p. 1900).

4. Provide credential recognition or evaluation services to foreign-trained counselling practitioners to become recertified or licensed in Canada and who can offer a holistic approach to counselling from an intercultural perspective (p. 1900).

Building rapport, safety, and trust is important to the settlement practitioner-immigrant senior relationship. 
Chia is a client of Sally's. Sally works for a local immigrant settlement agency. She is an intake worker in the counselling department. Sally and Chia have met several times during Chia's settlement process, from landing to registering for Englishlanguage classes and discussing community activities of interest. Today's conversation between Sally and Chia is a bit different because Chia has opened up to Sally about a potential abuse situation at home.

Chia: Good morning, Sally. How are you today?

Sally: I am well, thank you! It's nice to see you. How are you doing?

Chia: I am okay. My grandchildren keep me busy. They are so smart, but they have so much energy all the time.

Sally (nods and maintains eye contact): Oh, I see. Before we get started with today's conversation, do you want some tea or water?

Chia: Tea would be good. Do you have green tea?

Sally: Yes, I do! Do you want any milk or sugar in your tea?

Chia: No milk, no sugar.

Sally: So, just a reminder that I will be taking notes so that I can keep track of what you have shared, but I will be listening to make sure that I capture your thoughts. The notes I take will be seen by you and me. If I want to share the notes, I will always ask your permission first. Is that okay?

Chia: Yes.

Sally: Can you please complete this consent form while I get your tea.

Chia: Yes, for sure.

(Pause)

Sally: Here you are. I hope you are comfortable. Let me know if there is anything else you need.

Chia: No, thank you. I am good. Thank you so much. 
Sally: You were saying that your grandchildren keep you busy. Can you tell me a bit about a typical day?

Chia: Oh, I wake up at 6:00 a.m. to prepare their breakfast and get their clothes ready. Then I get them to brush their teeth and eat breakfast. Next, I walk them to school. Sometimes it is very cold when I come back home. Then I clean up the dishes and the bathroom and prepare lunch when they come home to eat. Next, I prepare dinner for my children and grandchildren and maybe do some laundry if there is time.

Sally (nods): And do you feel at the end of a day like this?

Chia: Tired. I am not as fast as I was before, but I help my daughter and my son-in-law because they work a lot and are busy, and I do not want my son-in-law to be angry with me.

Sally: Hmmm. Why do you think your son-in-law would be angry? Chia: He said that he brought me here, so I need to help as much as possible. He does everything for me. I do not have to worry about food or clothes or anything. Sometimes he yells if I forget something, but I do not want the children to see him angry, so I do my best to do things right.

Sally: Hmmm. What happens if you do not do things right?

Chia: It causes problems with my son-in-law and me or my son-inlaw and his wife. I feel bad, but I cannot say anything.

Sally: Hmmm. Thank you for sharing. I am going to restate what I heard. You make breakfast and lunch for your grandchildren and walk them to and from school. You also make dinner and do some laundry for the family. You sometimes feel sad when your son-inlaw is angry, and sometimes you feel tired.

Chia: Yes.

Sally: This sounds like a lot of work, and you are doing some things to help your children and grandchildren.

Chia: Yes, but I want to help because they are my family. I do not have lots of family back home. 
Sally: Let us talk a little bit about what you like to do. Are you still attending English classes in the evening?

Chia: Sometimes, but my daughter says she cannot take me if she has to work late.

Sally: Would you like to have a free bus pass so you can go to class on your own?

Chia: Yes! That would help me.

Sally: There is also a potluck in four weeks with other newcomers. Do you want to go?

Chia: What time?

Sally: It is in the evening at 6:00 p.m.

Chia: I could go. Can you write down the date and time for me, please?

Sally: Yes, I will do that.

Chia: Thank you!

Sally: I am going to share your file with our counsellor, Jenny. She may want to talk with you in a few days. Is that okay?

Chia: Yes, that is okay. I like coming to talk to people.

Sally: Great! I will make an appointment and write it down for you. (Pause)

Sally: Does this date and time work?

Chia: Yes, that is fine. The grandchildren are at school.

Sally: Awesome! I will see you soon. Take care.

Chia: Okay. Bye!

This role-play scenario shows the rapport and relationship-building between the settlement practitioner and the client. Notice that the settlement practitioner does not jump to conclusions and ask 
questions about violence because the client has not indicated that there is violence. Caution should be taken to be sensitive to the client's cultural and family traditions.

\section{Reflection}

1. What was your initial reaction to the situation?

2. What did you notice about the communication between the settlement practitioner and the client?

The conversation between Chia and Sally is one example of cultural grandparenting expectations. The conversation begins a discussion around the norms and attitudes of the marginalized older immigrant person and immediate family members about the older immigrant parent's role in the household in Canada. Elder abuse among Chinese immigrants and racial minority groups should be framed based on individual family characteristics such as roles, relationships, living arrangements, social networks, and informal and formal supports. Elder abuse should be examined from multiple contextual experiences and influences with a focus on the individual's life transitions, such as family and social roles, interactions, and intergenerational relationships among adult children, grandchildren, and the elder immigrant person.

\section{INSTRUCTOR NOTE}

This activity can be done in pairs. If utilized in the OER, learners may choose to read through or listen to the role play. 


\section{Summary}

\section{Discussion with Focused Questions}

1. What are some of the reasons immigrant seniors choose to immigrate later in life to Canada? What are some of the challenges with aging out of place?

Immigrant seniors migrate to Canada because of conflict or family ties. Immigrant seniors who are sponsored by family members may arrive under an economic or parent or grandparent program, and resettlement may be impacted by adult children's ability to provide financially. Cultural perspectives on elder responsibilities in the adult child or caregiver home differ, but generally speaking, older immigrants were once regarded as knowledge keepers of tradition. Migrating to Canada later in life may lead to challenges with aging out of place because some older immigrants feel a loss of autonomy, social connections, and respect. Other older immigrants find ways to connect in their new communities.

2. What does effective communication look like between a settlement practitioner and an immigrant senior client?

Elderly immigrants want to maintain their dignity in all interactions, particularly those in unfamiliar spaces. Maintain an appropriate personal space with clients, and call new clients by their last name as a sign of respect until the client indicates that using their first name is appropriate. Avoid multi-tasking when speaking with the elderly person, and avoid jargon. Provide short amounts of information at a time to avoid confusion. Evaluate your personal assumptions about ability, gender, ethnicity, and age, and identify times when a statement about a group of people is made. Finally, avoid "elder speak" (communication that infantilizes the adult). 
3. What should the settlement practitioner consider when evaluating a client's needs?

Listen empathetically. Maintain appropriate eye contact, nod, and do not interrupt the client. Take notes and offer opportunities for supports based on the client's interests and statements. Ask "what if" statements and repeat what was said for clarity. Thank the client for their willingness to share their experiences. Provide a list of resources to build social supports where possible. Also provide opportunities for future follow-up to have difficult conversations with a licensed practitioner in the specialized and applicable field.

\section{Image Credit}

[Cooperate and connect] by johnhain, Pixabay licence 


\section{Chapter Learning Activities}

Learning Activity 6: Communicating with Older Adults

Directions: Watch the video Communicating with Older Adults, then answer the questions.

Gerontological Society of America. (2018, October 19). Communicating with older adults [Video]. YouTube. https://youtu.be/g_ ObKBXOvGU

\section{Adapted Script}

Which one of these adults is 65 years old? Older adults are living longer, and many are leading and living healthy lifestyles. Too often, healthcare professionals see only the age of the patient and not the patient's unique situation. If we make assumptions based on stereotypes and talk down to older patients instead of listening carefully and engaging compassionately, we miss important signs. This breakdown in communication can lead to misdiagnosis, improper treatment, medication mistakes, distrust, and patient dissatisfaction. As healthcare providers, it is important to build relationships with patients through mutual trust and understanding to produce positive, effective interactions and assessments. Avoid 
speech that older adults might interpret as patronizing . Ask openended questions and genuinely listen. If a computer is used during visits with older patients, consider switching to a model that facilitates collaborative use. Engage in shared decision making. The normal aging process can hinder communication between older adults and healthcare professionals. Focusing on clear communication techniques significantly increases the likelihood of a successful patient visit. It is important to build relationships with patients, and you get what you give. Monitor and control your nonverbal behaviour. Include older adults in the conversation even if their companion is in the room. Express understanding and compassion to help older patients manage fear and uncertainty related to the aging process and chronic diseases. Use visual aids such as pictures and diagrams to help clarify and reinforce the comprehension of key points. Healthcare providers are increasingly likely to experience communication challenges. Recognizing situations and focusing on how to convey vital information will be the keys to positively communication. Minimize background noise, verify listener comprehension, break away from stereotypes, and understand that chronological age is not biological age.

\section{Comprehension Questions}

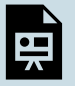

An interactive H5P element has been excluded from this version of the text. You can view it online here:

https://openeducationalberta.ca/settlement/?p=635\#h5p-26 
Directions: Watch the video Validation, communication through empathy, then complete the reflective task assignment that follows.

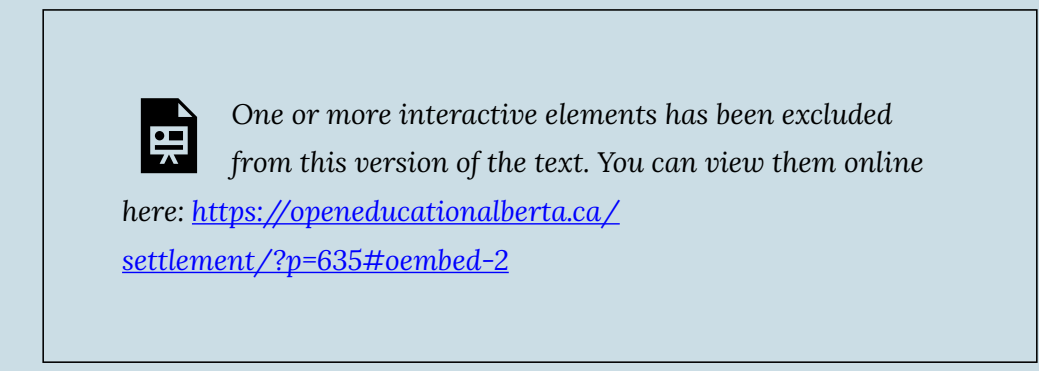

Tedx Talks. (2015, June 3). Validation, communication through empathy | Naomi Fell | TEDxAmsterdamWomen [Video]. YouTube. https://youtu.be/ESqfW_kyZq8

Write a 600- to 800-word reflection. Use double-spaced, Times New Roman 12-point font, and APA (7th edition) formatting. Answer the following questions:

1. What was the main idea of the talk?

2. What are the key points and why?

3. What themes about client needs were discussed?

4. How can you incorporate these ideas into your settlement practice? 


\section{Reflective Task Rubric}

\begin{tabular}{|c|c|c|c|c|}
\hline Criteria & $5-4$ & $3-4$ & $1-2$ & 0 \\
\hline $\begin{array}{l}\text { Main idea/Key } \\
\text { points/ } \\
\text { Themes/ } \\
\text { Application in } \\
\text { practice }\end{array}$ & $\begin{array}{l}\text { Learner } \\
\text { demonstrates a } \\
\text { thorough } \\
\text { understanding } \\
\text { of the content. } \\
\text { The answer is } \\
\text { supported by } \\
\text { experience } \\
\text { and/or draws } \\
\text { upon } \\
\text { information or } \\
\text { concepts } \\
\text { covered in the } \\
\text { unit. } \\
\text { Insightful } \\
\text { connections are } \\
\text { made relating } \\
\text { to the topic and } \\
\text { applied into } \\
\text { practice. }\end{array}$ & $\begin{array}{l}\text { Learner } \\
\text { demonstrates } \\
\text { some } \\
\text { understanding of } \\
\text { the content } \\
\text { relating to the } \\
\text { questions. } \\
\text { Personal or } \\
\text { professional } \\
\text { experience is } \\
\text { shared and } \\
\text { relates to the } \\
\text { topics/questions. } \\
\text { Ideas are } \\
\text { complete. }\end{array}$ & $\begin{array}{l}\text { Learner does not } \\
\text { demonstrate an } \\
\text { understanding of } \\
\text { the course } \\
\text { content as it } \\
\text { relates to the } \\
\text { questions. } \\
\text { Some connections } \\
\text { to the resource } \\
\text { and personal or } \\
\text { professional } \\
\text { experiences may } \\
\text { be shared, but } \\
\text { may not fully } \\
\text { relate to the } \\
\text { topics covered. }\end{array}$ & $\begin{array}{l}\text { Learner does not } \\
\text { respond to most } \\
\text { questions or the } \\
\text { response does } \\
\text { not relate to the } \\
\text { content in the } \\
\text { resource. } \\
\text { The learner does } \\
\text { not demonstrate } \\
\text { an } \\
\text { understanding of } \\
\text { the content } \\
\text { related to the } \\
\text { questions. }\end{array}$ \\
\hline
\end{tabular}




\begin{tabular}{|c|c|c|c|c|}
\hline $\begin{array}{l}\text { Message } \\
\text { (APA } \\
\text { formatting, } \\
\text { pagination, } \\
\text { spelling, and } \\
\text { grammar) }\end{array}$ & $\begin{array}{l}\text { Message is } \\
\text { clearly } \\
\text { communicated. } \\
\text { All sentences } \\
\text { are well written } \\
\text { with correct } \\
\text { spelling and } \\
\text { grammar. } \\
\text { APA formatting } \\
\text { is used } \\
\text { efficiently and } \\
\text { effectively. }\end{array}$ & $\begin{array}{l}\text { Message is fairly } \\
\text { clearly } \\
\text { communicated. } \\
\text { Most sentences } \\
\text { are well written } \\
\text { with few spelling } \\
\text { or grammar } \\
\text { errors. } \\
\text { APA formatting is } \\
\text { mostly correct. }\end{array}$ & $\begin{array}{l}\text { Message is not } \\
\text { clearly } \\
\text { communicated. } \\
\text { Writing is } \\
\text { challenging to } \\
\text { understand, and } \\
\text { as a result, the } \\
\text { message is lost. }\end{array}$ & $\begin{array}{l}\text { There are } \\
\text { significant } \\
\text { writing } \\
\text { challenges that } \\
\text { make } \\
\text { understanding } \\
\text { the message } \\
\text { challenging. }\end{array}$ \\
\hline
\end{tabular}

\section{Learning Activity 8: Cross-Cultural Intercultural Communication in Settlement Situations}

Learning Activity 8: Cross-Cultural Intercultural Communication in Settlement Situations

Directions: Read the situations and answer the questions that follow. Use what you have learned about communicating with seniors. Consider the video in Activity 2. Hand in your responses to the instructor.

\section{INSTRUCTOR NOTE}

This activity can also be done in pair groups or as a large group discussion. 


\section{Exercise I: Waiting for an Appointment}

Rakhi: You are an older immigrant waiting for assistance at a settlement office. You are not very steady on your feet because of an injury, and you need to use a walking stick. The office is quite busy with a lot of foot traffic, and you have been waiting for an appointment that should have started 10 minutes ago.

Donald: You are the settlement practitioner. It is a busy time of day, and there are a lot of people in the waiting area. You are running 10 minutes behind schedule. You can see that several people are waiting, including an older person.

\section{Questions:}

1. How do you think Rakhi is feeling in the waiting area?

2. How do you handle this situation?

3. How would you evaluate client need?

4. What should you say or not say to build trust?

5. How could you start a conversation based on empathy with this client?

Answers may vary. 


\section{Exercise 2: The Hospital}

Elza: You are an older immigrant at the hospital. You are waiting to see a doctor. You have a lot of pain in your joints. Your daughter dropped you off and had to go to work. You have to take the bus to get home.

Doctor: You are a doctor at Westhills Hospital. A few people are waiting. You are short-staffed because one of the nurses on your unit is sick.

Interpreter: You are asked to provide information about Elza to the doctor. This includes the reason for the visit and personal information. You are tired. It is well past lunchtime, and you have not had your lunch break yet. The older person is distracted by the noise and cannot hear the questions well.

\section{Questions:}

1. How do you think Elza is feeling in the waiting area?

2. How do you handle this situation?

3. How would you evaluate client need?

4. What should you say or not say in order to build trust?

5. How could you start a conversation based on empathy with this client?

Answers may vary.

\section{Learning Activity 9: Communication Accommodation}




\section{Theory in Action}

Learning Activity 9: Communication Accommodation Theory in Action

Directions: Watch the video Communication Accommodation Theory and complete the matching task that follows.

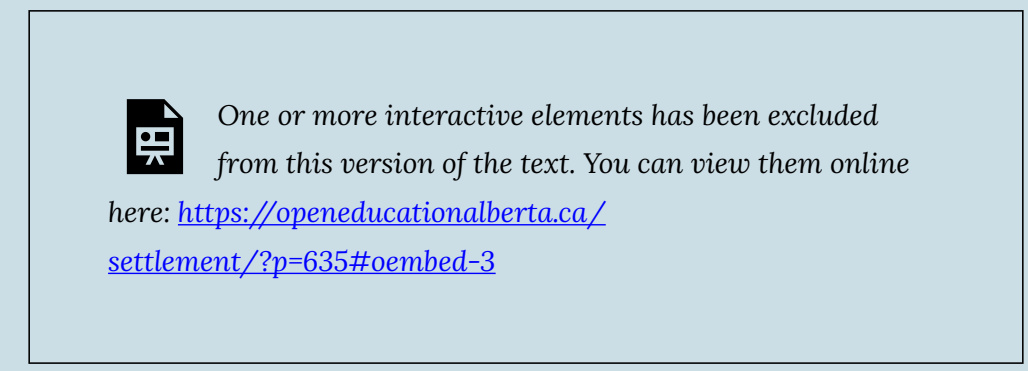

MAFERBENITES. (2018, February 18). Communication accommodation theory [Video]. YouTube. https://youtu.be/FY-jqjWjEC8

Learning Activity Io: Matching - Convergence or Divergence in Communication Accommodation Theory

Learning Activity 10: Convergence or Divergence in Communication Accommodation Theory 
https://openeducationalberta.ca/settlement/?p=635\#h5p-27

228 | Chapter Learning Activities 


\section{Problem Solving Through Case Studies}

Directions: Read each case study and answer the questions.

Note: These case studies are all fictitious but are based on scenarios you may encounter in the settlement field.

\section{Case Study i: Awek's Health Dilemma}

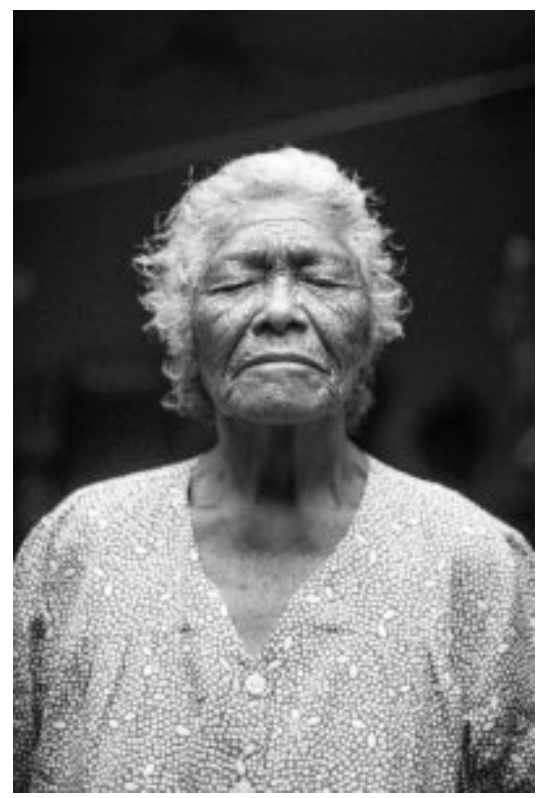

Problem Solving Through Case 
Awek is a newcomer to Red Deer and has moved in with her oldest daughter and her family. She arrived from South Sudan in August. She has experienced some arthritis in her knee since arriving in Canada. Her family's current healthcare situation does not cover physiotherapy, and Awek is afraid that she will become more ill without getting to see a specialist. Because she is elderly, she cannot work a standard job to pay for her own benefits. Awek has been using traditional naturopathic herbal remedies and refuses to go to the refugee health centre for a referral because she cannot afford the treatment.

An interactive H5P element has been excluded from this version of the text. You can vie https://openeducationalberta.ca/settlement/?p=234\#h5p-17

\section{Case Study 2: Adult Child and Elder Parent Conflict}




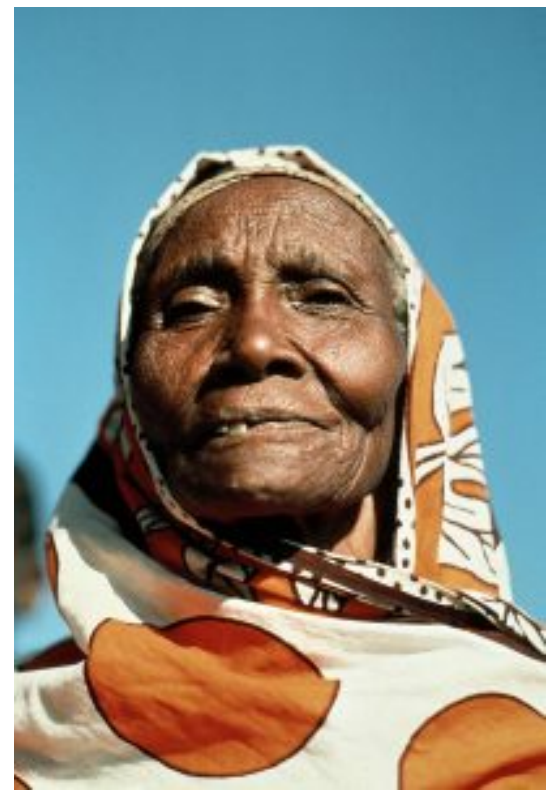

Three years ago, a young couple with three small children sponsored their elderly mother from Kenya to come live with them. They live in a suburban community in Calgary. The relationship is mutually beneficial because the mother is able to live with the couple and all of her medical, living, and food expenses are paid for by her adult children. The daughter-in-law was recently laid off from work. Since she arrived, the grandmother has been taking care of the children before and after school. Conflict has arisen because the grandmother wants to raise her grandchildren in a traditional manner. The daughter-in-law, however, wants to raise the children based on Canadian culture and expectations and wants the grandmother to leave the parenting to the parents. The daughter-in-law has said in anger that since she is now without a job, the grandmother should return to the home country because they no longer need her to look after the children. The grandmother is feeling anxious.

.

An interactive H5P element has been excluded from this version of the text. You can viev https://openeducationalberta.ca/settlement/?p=234\#h5p-18 


\section{Case Study 3: Isolation}

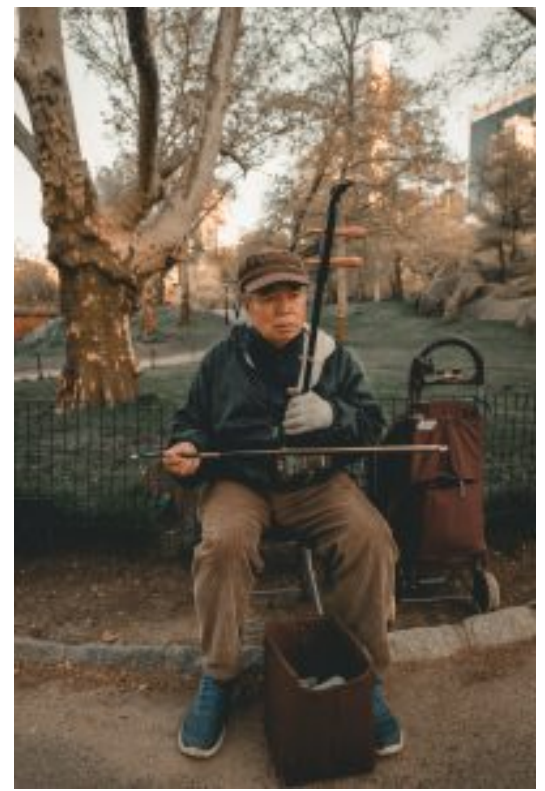

An elderly father arrived from China three weeks ago and is now living in Fort McMurray with his only son. The immigrant senior is a widower and is concerned that his son is not yet married. The son often works long hours and is away most of the work week. The son sometimes stays on the job site over the weekend during the winter months because travel is not always easy at that time. The father has been feeling isolated. The senior was an avid musician in his country of origin and speaks three languages. The father is looking for opportunities to mentor young people in his ethnocultural community. 
An interactive H5P element has been excluded from this version of the text. You can view it online here:

https://openeducationalberta.ca/settlement/?p=234\#h5p-19

\section{Case Study 4: Grandparent Challenges}

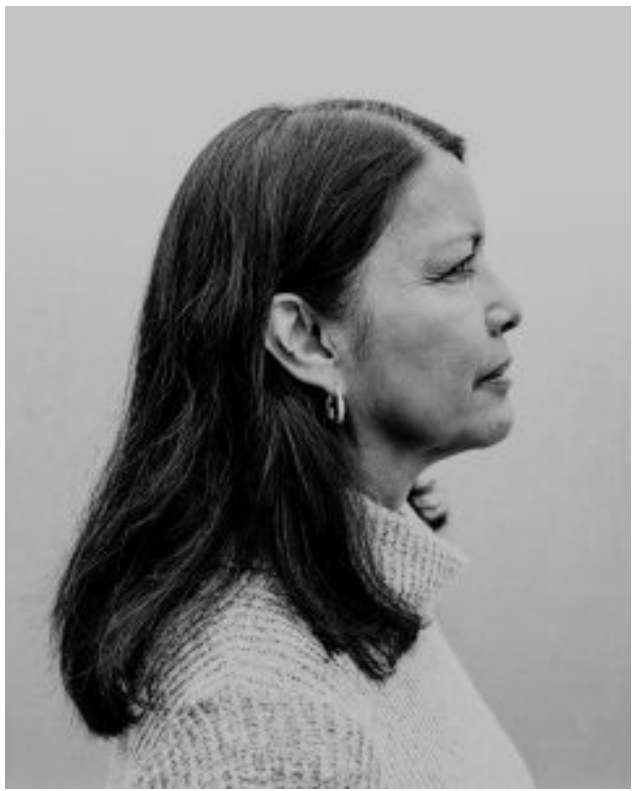

You are meeting with an elderly Filipino woman and her granddaughter. The older woman has asked her granddaughter to leave the house because the granddaughter was caught drinking. The grandmother got upset and said that alcohol is a drug because it is addictive. The grandmother is deeply religious. She has expressed anxiety because the granddaughter brings strange people to the house, and sometimes they stay the night. The grandmother feels that this behaviour is shameful and does not want to go out to cultural events in the Filipino community. 
An interactive H5P element has been excluded from this version of the text. You can view it online here:

https://openeducationalberta.ca/settlement/?p=234\#h5p-20

\section{Case Study 5: Trauma and Resettlement}

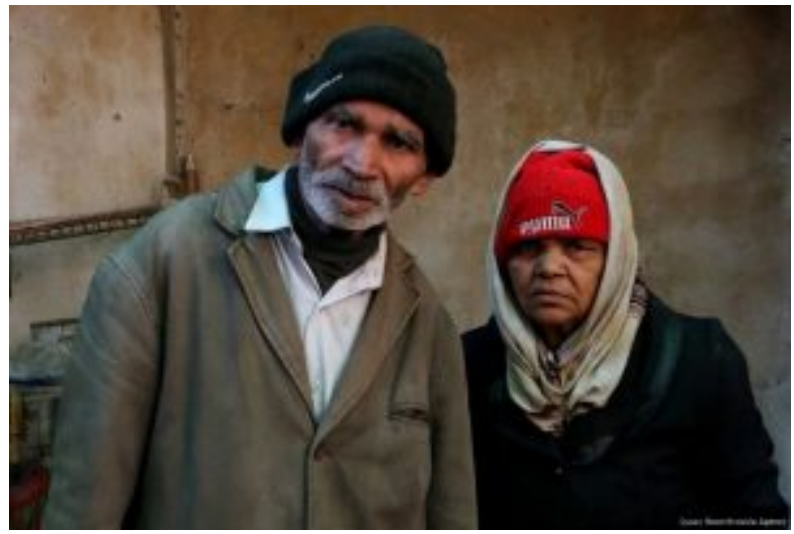

An elderly couple has emigrated from Syria to Edmonton. They are experiencing post-traumatic stress, and the husband recently suffered a mild stroke. They are also experiencing culture shock and anxiety. They are not accustomed to the healthcare system and miss their community of friends. They are having difficulty getting used to the weather, food, and public transportation.

\section{㘢}

An interactive H5P element has been excluded from this version 
of the text. You can view it online here:

https://openeducationalberta.ca/settlement/?p=234\#h5p-21

\section{Image Credits (images listed in order of appearance)}

Old woman closing her eyes by Danie Franco, Unsplash licence

Focus on the Elderly: The World Assembly on Aging - An elderly woman of Kisumu, Kenya by United Nations Photo, CC BY-NC-ND 2.0 Generic licence

Playing a memory by Clay Banks, Unsplash licence

Older woman by Noah Blaine Clark, Unsplash licence

[A Pakistani man and his wife in Syria under blockade] by Middle East Monitor, CC BYNC-SA 4.0 International licence 


\section{Key Terms and Definitions}

므 An interactive H5P element has been excluded from this version of the text. You can view it online here:

https://openeducationalberta.ca/settlement/?p=852\#h5p-34 


\section{Conclusion}

Immigrant seniors play an integral role in Canadian cultural experiences. They provide insights into the traditional customs and histories of their ancestors and pass on meaningful traditions to second- and third-generation immigrant children, which adds to Canada's diverse cultural landscape. Immigrant seniors

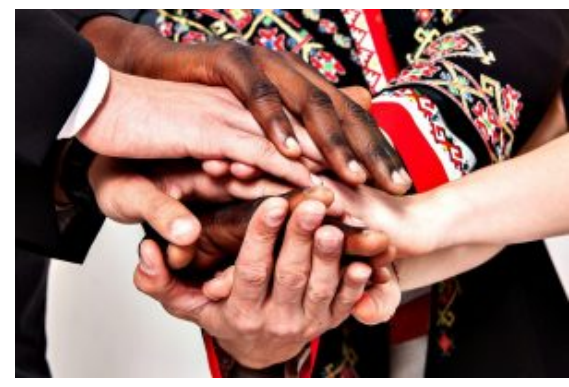
also play a vital role in the ethnocultural communities in which they live and serve, acting as volunteers, mentors, and role models. The role of settlement practitioners in local immigrant partnership agencies is integral to the successful integration of immigrant seniors to Canada's welcoming communities. Immigrant seniors who access support services are better equipped to navigate Canadian transportation, educational, legal, and healthcare systems. This, in turn, helps to build independence among immigrant seniors.

Settlement practitioners must be able to evaluate client need from multiple lenses to reconcile the impacts of racism and how it affects the health and well-being of elderly immigrants, recognizing that stereotypes and microaggressions are demeaning and harmful to the emotional well-being of immigrant seniors. The role of the practitioner is to provide service ethically by using communicative devices in their work with diverse immigrant seniors. Finally, the practitioner must recognize that not all migration stories are the same, and as such, case management is unique to each situation and should be evaluated and carefully considered before making assumptions, connections, or suggestions.

\section{Image Credit}

Multiracial people joining hands by Leejoann, Pixabay licence 


\section{Optional Readings and Resources}

\section{Additional Resources}

Bell, N., Davis, L., Douglas, V., Gaywish, R., Hoffman, R., Lambe, J., Manitowabi, E., Mccaskill, D., Pompana, Y., Williams, D., \& Williams, S. (2005). Creating indigenous spaces in the academy: Fulfilling our responsibility to future generations. AlterNative: An International Journal of Indigenous Peoples, 1(1), 64-84. https://doi.org/10.1177/117718010500100105

De Haene, L., Robert, P., Adriaenssens, P., \& Verschueren, K. (2012). Voices of dialogue and directivity in family therapy with refugees: Evolving ideas about dialogical refugee care. Family Process, 51(3), 391-404. https://doi.org/10.1111/ j.1545-5300.2012.01404.x

Dong, X. (2012). Culture diversity and elder abuse: Implications for research, education, and policy. Journal of the American Society on Aging,36(3), 40-42. https://www.jstor.org/stable/26555931

Dong, X., Chang, E., Wong, E., Wong, B., \& Simon, M. A. (2011). How do U.S. Chinese older adults view elder mistreatment? Findings from a community-based participatory research study. Journal of Aging \& Health, 23(2), 289-312. DOI: 10.1177/ $\underline{0898264310385931}$

Dong, X., Simon, M., Beck, T., \& Evans, D. (2010). A cross-sectional population-based study of elder self-neglect and psychological, health, and social factors in a biracial community. Aging \& Mental Health, 14(1), 74-84. DOI: $\underline{10.1080 / 13607860903421037}$

Dong, X., Simon, M., \& Evans, D. (2013). Elder self-neglect is associated with increased risk for elder abuse in a community-dwelling population: Findings from the Chicago Health and Aging Project. Journal of Aging \& Health, 25(1), 80-96. DOI: 10.1177/ $\underline{0898264312467373}$

Dong, X., Simon, M. A., Fulmer, T., Mendes de Leon, C. F., Hebert, L. E., Beck, T., Scherr, P. A., \& Evans, D. A. (2011). A prospective population-based study of differences in elder self-neglect and mortality between black and white older adults. Journals of Gerontology Series A: Biological Sciences \& Medical Sciences, 66(6), 695-704. DOI: $10.1093 /$ gerona/glr053

Lachs, M. S., Williams, C., O’Brien, S., Hurst, L., \& Horwitz, R. (1997). Risk factors for reported elder abuse and neglect: a nine-year observational cohort study. Gerontologist, 37(4), 469-474. DOI: 10.1093/geront/37.4.469 
Lachs, M. S., Williams, C. S., O’Brien, S., Pillemer, K. A., \& Charlson, M. E. (1998). The mortality of elder mistreatment. Journal of the American Medical Association, 280(5), 428-432. https://jamanetwork.com/journals/jama/fullarticle/187817

Lai, D., Daoust, G., \& Li, L. (2014). Understanding elder abuse and neglect in aging Chinese immigrants in Canada. Journal of Adult Protection, 16(5), 322-334. https://doi.org/10.1108/JAP-03-2014-0006

Mometrix Academy. (2017, October 11). Counseling: Multicultural clients [Video]. YouTube. https://www.youtube.com/watch?app=desktop\&v=3n54C6rNito

O’Reilly, D., \& Barke, J. (2016, November 1). Counselling Skills - Diversity [Video]. YouTube. https://www.youtube.com/watch?app=desktop\&v=sErapRr-Na0

Refugee Council. (2015, April 5). Refugee health professionals: Communication and cross-cultural issues [Video]. YouTube. https://www.youtube.com/watch?v=WR3y99SWmM

Walker, J., \& Zuberi, D. (2020). School-aged Syrian refugees resettling in Canada: Mitigating the effect of pre-migration trauma and post-migration discrimination on academic achievement and psychological well-being. Journal of International Migration and Integration, 21(2), 397-411. https://doi.org/10.1007/ $\underline{\text { s12134-019-00665-0 }}$ 


\section{Chapter References and Attributions}

\section{References}

Canadian Museum of Immigration Pier 21. (2010). Oral history 10.04.08EK with Eunsun Kim [Audio file]. https://pier21.ca/content/oral-history-100408ek-with-eunsun$\underline{\operatorname{kim}}$

Dam, H., \& Wayland, S. V. (2019). Syrian refugee resettlement: A case study of local response in Hamilton, Ontario. The Canadian Geographer,63(3), 360-373. https://doi.org/10.1111/cag.12560

Dong, X. (2005). Medical implications of elder abuse and neglect. Clinical Geriatric Medicine, 21(2), 293-313.

Este, D. C., \& Tachble, A. (2009). Fatherhood in the Canadian context: Perceptions and experiences of Sudanese refugee men. Sex Roles, 60(7), 456-466. https://doi.org/ $\underline{10.1007 / \text { s11199-008-9532-1 }}$

Government of Canada. (2013). Local immigration partnerships handbook: Citizenship and immigration Canada. https://p2pcanada.ca/wp-content/uploads/2013/02/ CIC-Local-Immigration-Partnerships-Handbook.pdf

Government of Canada, Justice Laws Website. (2014). Canadian Multiculturalism Act (R.S.C., 1985, c. 24 (4th Supp.)). https://laws-lois.justice.gc.ca/eng/acts/c-18.7/ page-1.html

Guo, S., \& Guo, Y. (2016). Immigration, integration and welcoming communities: Neighbourhood-based initiative to facilitate the integration of newcomers in Calgary. Canadian Ethnic Studies,48(3), 45-67. https://doi.org/10.1353/ ces. 2016.0025

Guruge, S., Kanthasamy, P., Kokarasa, J., Wan, T. Y. W., Chinichian, M., Shirpak, K. R., Paterson, P., \& Sathananthan, S. (2010). Older women speak about abuse \& neglect in the post-migration context. Women's Health and Urban Life, 9(2), 15-41. https://tspace.library.utoronto.ca/bitstream/1807/25498/1/9.2 guruge etal.pdf

Kei, W., Seidel, M., Ma, D., \& Houshmand, M. (2019, December 3). Results from the 2016 census: Examining the effect of public pension benefits on the low income of senior immigrants. Statistics Canada. https://www150.statcan.gc.ca/n1/pub/75-006-x/ $\underline{2019001 / \text { article/ }}$ 
00017-eng.htm\#: :text=Among\%20senior\%20immigrants\%20who\%20landed,after \%20accounting\%20for\%20other\%20factors

Kennedy, A., McGowan, K., \& El-Hussein, M. (2020). Indigenous Elders' wisdom and dominionization in higher education: barriers and facilitators to decolonisation and reconciliation. International Journal of Inclusive Education. https://doi.org/ $\underline{10.1080 / 13603116.2020 .1829108}$

Kim, E. (2010). Oral history 10.04.08EK with eunsun kim. Canadian Museum of Immigration Pier 21. https://5104.sydneyplus.com/final/portal.aspx?lang=en-US

King-Shier, K., Lau, A., Fung, S., LeBlanc, P., \& Johal, S. (2018). Ethnocultural influences in how people prefer to obtain and receive health information. Journal of Clinical Nursing, 27(7-8), 1519-1528. https://doi.org/10.1111/jocn.14281

Kwak, G., \& Lai, D. (2018). Social support and elderly Korean Canadians: A case study in Calgary. In S. Noh, A. Kim, \& M. Noh (Eds.), Korean immigrants in Canada: Perspectives on migration, integration, and the family (pp. 213-233). University of Toronto Press. https://doi.org/10.3138/9781442690387-015

Lachs, M. S., Williams, C. S., O’Brien, S., \& Pillemer, K. A. (2002). Adult protective service use and nursing home placement. Gerontologist, 42(6), 734-739. DOI: 10.1093/ geront/42.6.734

Lai, D. (2011). Abuse and neglect experienced by aging Chinese in Canada. Journal of Elder Abuse \& Neglect, 23(4), 326-347. https://doi.org/10.1080/ $\underline{08946566.2011 .584047}$

Likupe, G., Baxter, C., \& Jogi, M. (2018). Exploring health care workers' perceptions and experiences of communication with ethnic minority elders. Quality in Ageing, 19(3), 180-190. https://doi.org/10.1108/QAOA-08-2017-0034

Lithwick, M., Beaulieu, M., Gravel, S., \& Straka, S. M. (1999). The mistreatment of older adults: perpetrator-victim relationships and interventions. Journal of Elder Abuse and Neglect, 11(4), 95-112. https://doi.org/10.1300/J084v11n04 07

Mandell, N., Hemphill, J., Borras, J., \& Phonepraseuth, J. (2019, September 1). Settlement experiences of recently arrived senior immigrants. CERIS. https://ocasi.org/sites/ default/files/iwys-primary-research-seniors-final-report $0 . p d f$

McDonald, L. (2011). Elder abuse and neglect in Canada: the glass is still half full. Canadian Journal of Aging, 30(3), 437-465. DOI: 10.1017/S0714980811000286

McDonald, L., \& Collins, A. (2000). Abuse and neglect of older adults: A discussion paper. Government of Canada. https://publications.gc.ca/site/eng/9.647143/ publication.html 
Mendicino, M. E. L. (2020). 2020 annual report to Parliament on immigration. Immigration, Refugees and Citizenship Canada. https://www.canada.ca/content/ dam/ircc/migration/ircc/english/pdf/pub/annual-report-2020-en.pdf

Momand, B., \& Dubrowski, A. (2020). Addressing social context in health provider and senior communication training: What can we learn from communication accommodation theory? Curēus, 12(12), e12247-e12247. https://doi.org/10.7759/ $\underline{\text { cureus. } 12247}$

Noh, S., Kim, A., \& Noh, M. (2018). Korean Immigrants in Canada: Perspectives on migration, integration, and the family. University of Toronto Press. https://doi.org/ $\underline{10.3138 / 9781442690387}$

Nyamweru, C., \& Chidongo, T. (2018). Elders in modern Kenya: Dying institutions or reinventing themselves? African Studies, 77(2), 240-256. https://doi.org/10.1080/ $\underline{00020184.2018 .1452857}$

Podnieks, E. (2008). Elder abuse: the Canadian experience. Journal of Elder Abuse and Neglect, 20(2), 126-150.

Podnieks, E. (1993). National survey on abuse of the elderly in Canada. Journal of Elder Abuse \& Neglect, 4(1/2), 5-58.

Sadarangani, T. R., \& Jun, J. (2015). Newly arrived elderly immigrants: A concept analysis of "aging out of place." Journal of Transcultural Nursing, 26(2), 110-117. https://doi.org/10.1177/1043659614549074

Sheets, D. J., \& Gallagher, E. M. (2013). Aging in Canada: state of the art and science. Gerontologist, 53(1), 1-8. https://doi.org/10.1093/geront/gns150

Simich, L., Hamilton, H., \& Baya, B. K. (2006). Mental distress, economic hardship and expectations of life in Canada among Sudanese newcomers. Transcultural Psychiatry, 43(3), 418-444. https://doi.org/10.1177/1363461506066985

Spencer, C. (2000). Exploring the social and economic costs of abuse later in life. https://econwpa.ub.uni-muenchen.de/econ-wp/le/papers/0004/0004006.pdf

Statistics Canada. (2003). Family violence in Canada: A statistical profile. Catalogue no. 85-224-XIE. https://www150.statcan.gc.ca/n1/en/pub/85-224-x/ 85-224-x2003000-eng.pdf?st=rxDMP7rG

Stewart, M., Kushner, K. E., Dennis, C., Kariwo, M., Letourneau, N., Makumbe, K., Makwarimba, E., \& Shizha, E. (2017). Social support needs of Sudanese and Zimbabwean refugee new parents in Canada. International Journal of Migration, Health and Social Care,13(2), 234-252. https://doi.org/10.1108/ IJMHSC-07-2014-0028 
Straiton, M. L., Ledesma, H. M. L., \& Donnelly, T. T. (2018). "It has not occurred to me to see a doctor for that kind of feeling: a qualitative study of Filipina immigrants' perceptions of help seeking for mental health problems. BMC Women's Health, 18, 73. https://bmcwomenshealth.biomedcentral.com/articles/10.1186/ $\underline{\text { s12905-018-0561-9 }}$

Thomson, M. S., Chaze, F., George, U., \& Guruge, S. (2015). Improving immigrant populations' access to mental health services in Canada: A review of barriers and recommendations. Journal of Immigrant and Minority Health, 17(6), 1895-1905. https://doi.org/10.1007/s10903-015-0175-3

Yan, E. (2015). Elder abuse and help-seeking behavior in elderly Chinese. Journal of Interpersonal Violence,30(15), 2683-2708. https://doi.org/10.1177/ $\underline{0886260514553628}$

Zhang, W. (2019). Perceptions of elder abuse and neglect by older Chinese immigrants in Canada. Journal of Elder Abuse \& Neglect, 31(4-5), 340-362. https://doi.org/ $\underline{10.1080 / 08946566.2019 .1652718}$

\section{Media Attributions}

Gerontological Society of America. (2018, October 19). Communicating with older adults [Video]. YouTube. https://youtu.be/g_ObKBXOvGU

MAFERBENITES. (2018, February 18). Communication accommodation theory [Video]. YouTube. https://youtu.be/FY-jqjWjEC8

Tedx Talks. (2015, June 3). Validation, communication through empathy | Naomi Fell | TEDxAmsterdamWomen [Video]. YouTube. https://youtu.be/ESqfW kyZq8 



\section{CHAPTER 5: INTERCULTURAL COMPETENCE AND COMMUNICATION}





\title{
Introduction
}

\author{
JULIE CLEMENTS
}

\section{Overview}

Settlement professionals empower, support, and advocate for immigrants as they transition, settle, and successfully integrate into their new communities. Navigating this intercultural context presents challenges for both the settlement worker and the service user.

As a settlement professional, increasing intercultural competence allows you to show greater sensitivity and empathy towards service users who may find themselves in situations and surroundings that are uncomfortable and unfamiliar. Enhanced intercultural competence on the part of the settlement professional allows for specialized support of the service user throughout the settlement process.

In addition, developing intercultural competence allows you to recognize where their discomforts exist when working in an intercultural context. A deeper understanding of ourselves can help us understand the behaviours and actions of others. Situations can be viewed from another perspective that more appropriately informs our behaviours and actions.

With these goals in mind, this chapter will discuss what culture and intercultural competence are. Both topics will be explored, and a model for the development of intercultural competence will be discussed to support increasing self-awareness. An intercultural tool known as the D.I.E. Model will be discussed and applied to interpret a miscommunication. Culture general frameworks will be introduced as a tool for expanding cultural knowledge. Finally, an intercultural competence development plan will be introduced and explored to support future personal growth.

Specific Learning Outcomes

Upon successful completion of this chapter, you will be able to 
1. Define culture and intercultural competence

2. Recognize how a person's values and behaviours are culturally determined

3. Differentiate stages of intercultural competence development connecting to personal experience

4. Interpret a miscommunication using an intercultural tool (D.I.E Model) to construct an alternate perspective

5. Apply culture general frameworks to predict and understand possible miscommunications

6. Implement an action plan to develop your intercultural competence further

\section{Key Terms}




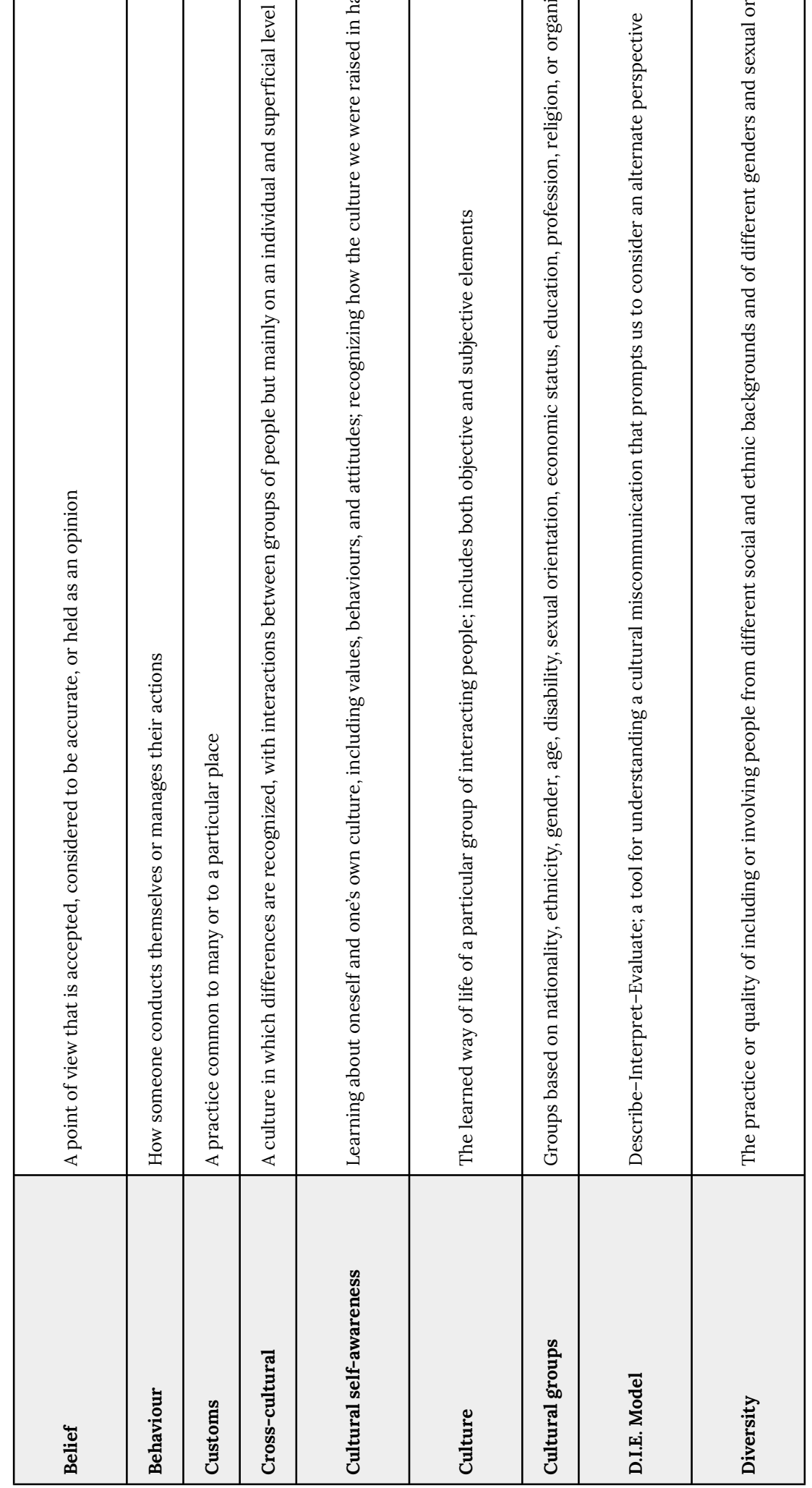




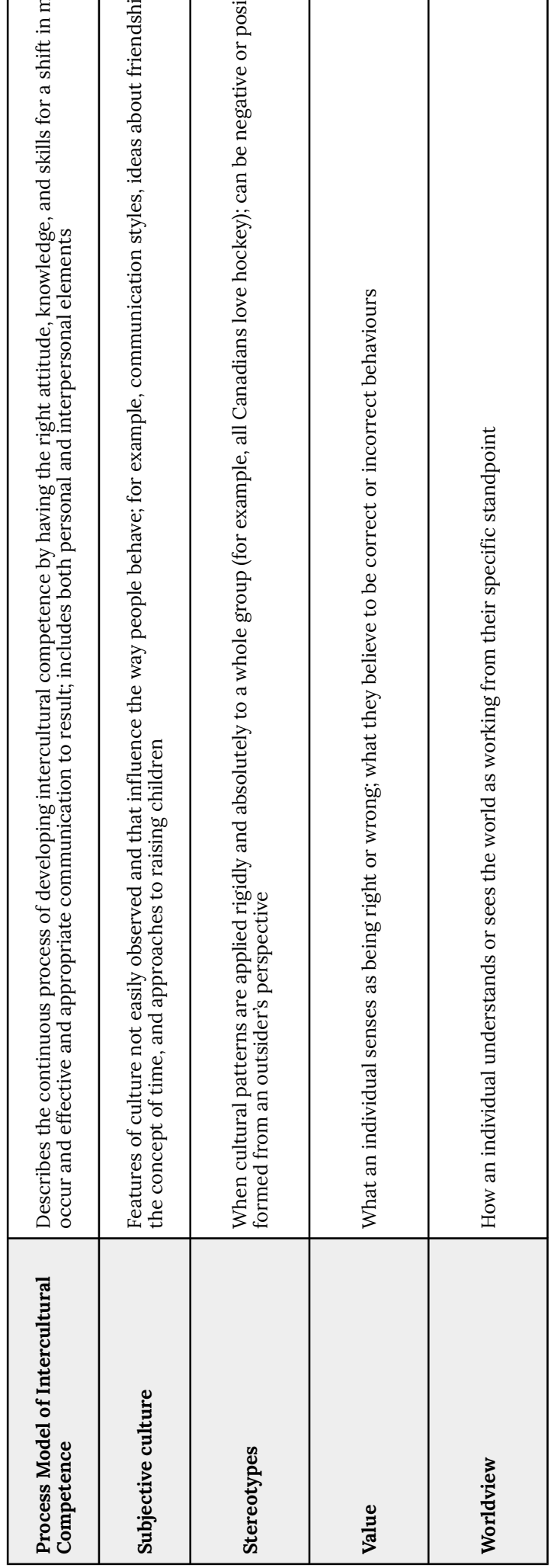




\title{
What is Culture and Intercultural Competence?
}

\author{
What is Culture?
}

This chapter explores the development of intercultural competence and communication. As a starting place, let us consider the following:

What is culture? How would you define culture? 


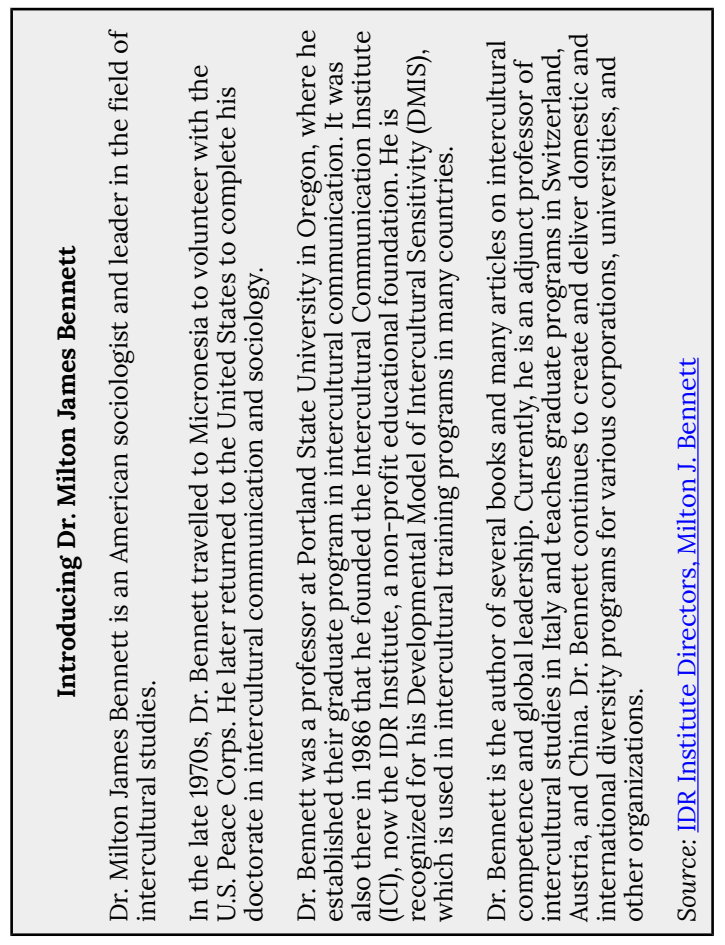


When you hear the word "culture," what do you think about? Culture is an umbrella term that is used in a lot of different contexts. Almost every day, we hear about trends and fads in popular culture and the media. In the business world, companies pride themselves on having a unique corporate culture. We might describe a sophisticated friend who has an appreciation for beauty and the finer things in life as being very "cultured."

For our exploration, culture can be thought of as "the learned and shared values, beliefs, and behaviours of a community of interacting people" (Bennett, 2001, p. 1). Culture includes language, food, dress, music, arts, literature, and the group's customs, beliefs, attitudes, and values.

Cultural groups can include ethnic, religious, or social communities, to name a few. Bennett (2004) further defined possible cultural groups explaining that

"the traditional definition of culture allows us to consider many of the wellknown groups defined in diversity work as cultures, including those based on nationality, ethnicity, gender, age, disability, sexual orientation, economic status, education, profession, religion, organization, and any other differences learned and shared by a group of interacting people" (p. 2).

This broad definition of cultural groups suggests just how complex our cultural identities are.

\section{Culture and Identity}

Any discussion or exploration of culture must recognize that culture significantly influences personal identity. Like culture, the term "identity" is commonly used in various contexts but means different things to different people. Because the word is used so often, many people assume that others know what they mean when they use the word. A proper definition that captures the actual complexities of the concept has never really been agreed upon (Fearon, 1999, p. 35).

In the late 1950s, Erik Erikson started the conversation on identity, and his definition of identity is still the most relevant and accepted today (Fearon, 1999, p. 35). Erikson is a German American psychologist known for his theory on human psychological development and for coining the term "identity crisis" (Schaetti, 2000, p. 5). Erikson broadly defined identity as an essential self-organizing principle that evolves throughout our lives. Further, he argued that identity gives us a sense of stability within ourselves and when interacting with others. It allows people to differentiate themselves from others and to act uniquely and independently.

Bonny Norton (1997), a leader in the field of identity and language learning, defines 
identity as "how people understand their relationship to the world, how that relationship is constructed across time and space, and how people understand their possibilities for the future" (p. 410).

While Erikson's definition of identity focuses on the internal dynamic, Norton's definition draws attention to the external ways in which our identity is shaped. Both definitions, however, emphasize the relational nature of identity; identity is about how we view ourselves in relation to others and the world around us.

Learning Activity 1: Reflection - Analogies for Culture

How do you understand these images as analogies for culture? How could each of the images represent how we think about or view culture? 

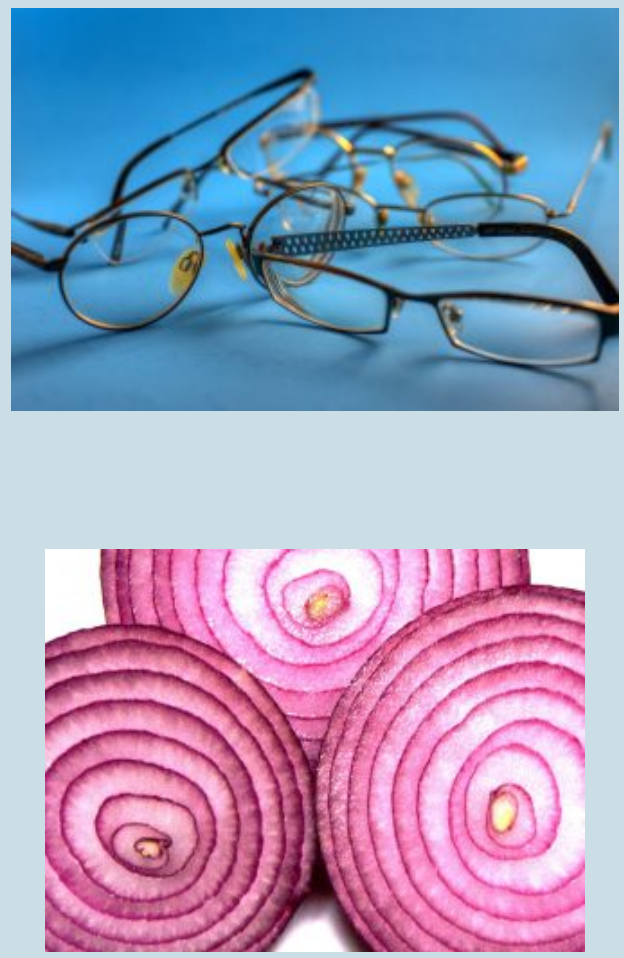

The images above represent ways culture can be thought about or viewed. Like the water to the fish in the fishbowl, the influence of our own culture is often not apparent to us. Eyeglasses represent the fact that we all wear our own cultural lenses when interpreting an event or situation. In the same way an onion has layers to be peeled back, layers of culture shape people. Understanding an individual requires peeling back the layers.

To sum up, these analogies give us insight into our own worldview and how the cultural lens through which we see the world is often invisible to us. Importantly, every individual has unique life experiences and a cultural identity shaped from and layered by their membership in numerous communities. It is an understanding of and 
appreciation for the complexity of an individual's culture that is a beginning place for the development of intercultural competence.

\section{Objective and Subjective Culture}

Edward T. Hall's (1976) Iceberg Model of culture is valuable for understanding the nuanced components of culture. If you have ever seen an iceberg, you will know that only a tiny portion of the iceberg is visible from the surface. Much of the iceberg exists under the surface.

Hall's Iceberg Model aptly makes the comparison to how culture works, and indeed, culture can be thought of like an iceberg. It is relatively easy to observe and learn many superficial aspects of culture such as language, traditional dress, foods, and music. It is much more challenging to observe and understand cultural elements that are not visible from the surface. These hidden facets of cultures, which influence core values and behaviours, are only revealed upon deeper examination over time.

\section{Hall's Cultural Iceberg Video}

Watch the video (1:30 min) below to learn more about Hall's Iceberg Model.

One or more interactive elements has been excluded from this
version of the text. You can view them online here: https://openeducationalberta.ca/settlement/?p=82\#oembed-1

GCPE BCGov. (2016, April 20). Cultural iceberg [Video]. YouTube. https://youtu.be/woP0v-2nJCU

Adding to the iceberg analogy, Bennett (1998) refers to the two aspects of culture as big " $\mathrm{C}$ " and small "c" culture (p. 2). Big " $\mathrm{C}$ " Culture encompasses the institutions of society, including features such as art, literature, drama, music, and dance. It also consists of what would be commonly studied or included in a history course, features such as social, economic, political, and linguistic systems. Big "C" Culture is the more objective culture, or the top of Hall's Iceberg Model. To Bennett, small "c" culture, on the other hand, is the less obvious. It is the day-to-day thinking and behaviour of a group of people-the learned and shared patterns resulting from groups of interacting 
people. It is how our values are determined and manifest themselves. Small "c" culture is the more subjective culture comparable to the bottom of Hall's Iceberg Model.

Although understanding a lot about big "c" Culture, or objective culture, creates knowledge, it does not necessarily mean we can communicate well with a person of that culture. In other words, this type of knowledge alone does not equate to intercultural competence. When we consider developing and maintaining relations, understanding small "c" culture (the invisible part of the iceberg) is critical. We need to understand the beliefs, behaviours, and values of a group. As Bennett (2001) reminds us, "It is this type of subjective culture that allows us insight into the worldview of another rather than a more superficial understanding" (p. 2).

\section{Learning Activity 2: Reflection - Working Across Cultures}

What insights do the culture analogies give us about working across cultures effectively?

\section{What is Intercultural Competence?}

Below, Figure 1 illustrates the meaning of three key terms: multicultural, crosscultural, and intercultural. Based on these images, how would you differentiate the three concepts? 
(a)

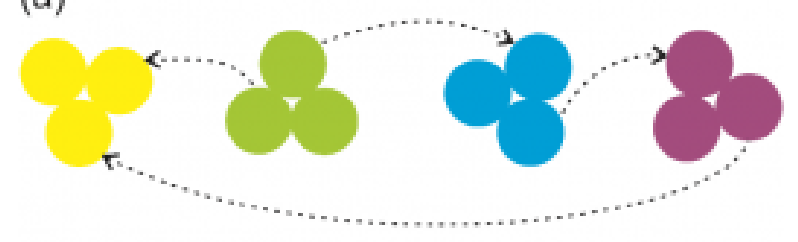

(b)

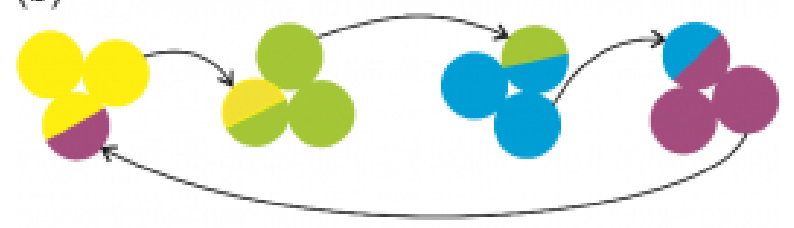

(c)

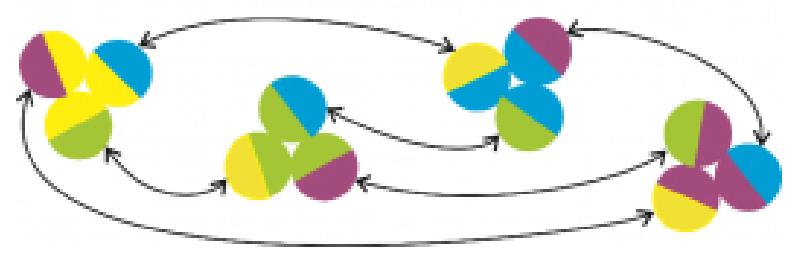

Figure 1. Image illustrating (a) multicultural, (b) cross-cultural and (c) intercultural (Schneider \& Heinecke, 2019, p. 14)

Canada is well known and recognized for being a multicultural country. Yet, what does that mean, and is being multicultural enough? Schriefer (2016) defined a multicultural society as consisting of people from various cultures or ethnic groups. Being multicultural does not, however, mean that there is meaningful interaction between these different communities.

Differences may be appreciated and recognized in a cross-cultural society, but any change in interactions is on an individual level instead of societal change. Other groups are compared to the dominant culture, which is the standard, or "norm."

Intercultural societies show deep comprehension and respect for differences. Members of an intercultural society learn and grow from one another. Interactions within the society lead to the mutual exchange of ideas and norms to build deeper relationships. In an intercultural society, no one is left unchanged. 
- How might a multicultural mindset affect settlement work?

- How might a cross-cultural mindset affect settlement work?

- How might an intercultural mindset affect settlement work?

Now that we have defined our understanding of culture and intercultural societies, what does it mean to be interculturally competent? Intercultural competence is generally accepted as the ability to interact effectively and appropriately across different cultures (Bennett, 2014, p. 4). The term "intercultural" suggests an ability to go between or among cultures, while "competence" suggests the ability to be effective and appropriate.

\section{- An interactive H5P element has been excluded from this version of the text. You can view it online here:}

https://openeducationalberta.ca/settlement/?p=82\#h5p-22

According to Bennett (2014), there are three components of intercultural competence-cognitive, affective, and behavioural (p. 5). From an intellectual standpoint, the most essential cognitive competency is our cultural self-awareness. It is difficult to appreciate the worldview of others without first becoming aware of our own cultural worldview. The most crucial affective competence is curiosity about other cultures. Part of intercultural competence is indeed learning about other cultures-both the superficial as well as the more profound ideas of the culture. Finally, according to Bennett, the most critical behavioural competency is empathy. Importantly, empathy in the context of intercultural competence is not the ability to see ourselves in another's shoes, but the ability to see the world from another's worldview.

"Cultural self-awareness refers to our recognition of the cultural patterns that have influenced our identities and that are reflected in the various culture 
groups to which we belong, always acknowledging the dynamic nature of both culture and identity."

(Bennett, 2014, p. 5)

From Bennett's competencies, we can see that intercultural competence is much more than a technical skill set to learn, but a mindset to embody. Furthermore, it begins which cultural self-awareness, which leads us to our first activity.

Learning Activity 4: Cultural Self-Awareness - The Identity Wheel

Intercultural competence is an intentional process. Before attempting to understand our interactions in intercultural settings, it is crucial as settlement professionals that we first have a clearer view of how our own culture has shaped our identity and the lens we use to see the world.

As we start thinking about our own personal cultural identity, creating an identity wheel is a valuable reflective exercise. As previously discussed, identity is how we see ourselves in relation to the world. It is the characteristics and roles that make us recognizable as members of cultural groups. Because we all belong to numerous cultural groups, we possess numerous identities. These groups or cultures in which we exist and which shape our identities make up the identity wheel. The goal of this activity is to identify the various cultures or subcultures that mould our identity.

\section{Instructions}

Access a PDF version of the Identity Wheel that you can edit to complete this activity here. 


\section{IDENTITY WHEEL}

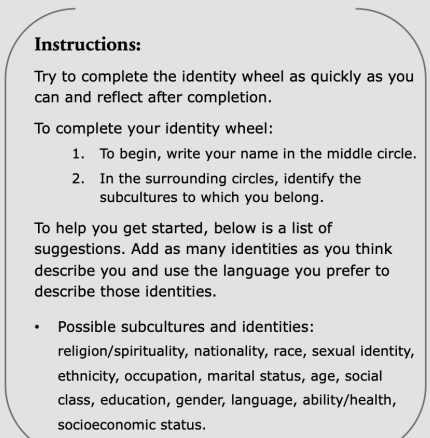

Try to complete the identity wheel as quickly as you can and reflect after completion.

To complete your identity wheel:

1. To begin, write your name in the middle circle.

2. In the surrounding circles, identify the subcultures to which you belong.

To help you get started, below is a list of suggestions. Add as many identities as you think describe you and use the language you prefer to describe those identities.

- Possible subcultures and identities:

religion/spirituality, nationality, race, sexual identity, ethnicity, occupation, marital status, age, social class, education, gender, language, ability/health, socioeconomic status.

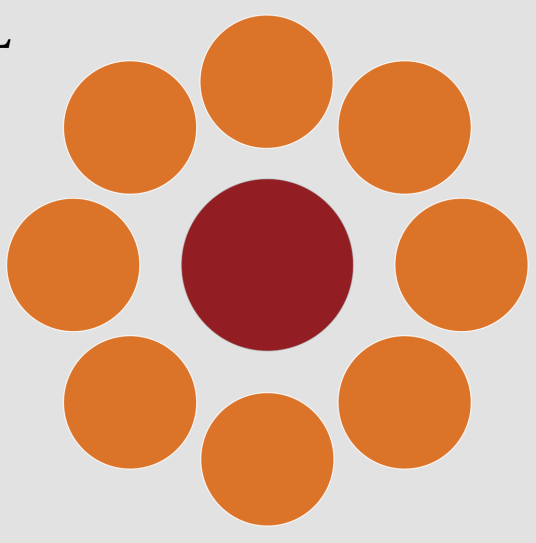

Post-Activity Reflection

1. Which identity did you write first?

2. Are there any identities that you had not thought of before today? Why do you think that is?

3. Which aspects of your identity feel especially meaningful to you and why? Which aspects feel less meaningful to you and why?

4. What identities have the most substantial effect on how you perceive yourself? On how others perceive you?

5. Are there identities you would like to learn more about? 
6. How did it feel to define yourself this way?

Image Credits (images are listed in order of appearance)

A30Y5W by KoiQuestion, CC BY-SA 2.0

Eyeglasses by Kent Landerholm, CC BY-SA 2.0

Mixed onions by Colin, CC BY-SA 3.0

Schneider, S., \& Heinecke, L. (2019). The need to transform science communication from being multicultural via cross-cultural to intercultural. Advances in Geosciences, 46, 11-19. DOI: 10.5194/adgeo-46-11-2019

Self-awareness by Guian Bolisay, CC BY 2.0 Generic licence

[Outline of head] by geralt, $\underline{\text { Pixabay licence }}$

[Diversity] by MetsikGarden, Pixabay licence 


\section{Improving Intercultural Competence}

\section{How We Experience Cultural Difference}

\section{Developmental Model of Intercultural Sensitivity (DMIS)}

The Developmental Model of Intercultural Sensitivity (DMIS) was created by Milton J. Bennett $(1998,2001,2004,2014,2017)$ to better understand and support people as they worked towards greater intercultural competency (Bennett, 2004, p. 1). The model and corresponding stages of the continuum were developed based on his observations of people in academic and business settings who were working on becoming more competent intercultural communicators.

Overall, the DMIS describes how we experience cultural differences. On this continuum, Bennett coined the terms "ethnocentric" and "ethnorelative" to describe the two opposing ends. The model describes how a person moves from avoiding difference (ethnocentrism) to seeking differences (ethnorelativism). Those at an ethnocentric stage see their beliefs and values as natural, correct, and unquestioningly the best way to live. They view their cultural experience as the reality. On the other hand, those who have a more ethnorelative view can see the world through a lens that acknowledges how their cultural beliefs, values, and ways of living represent only one of many possible and acceptable ways of living.

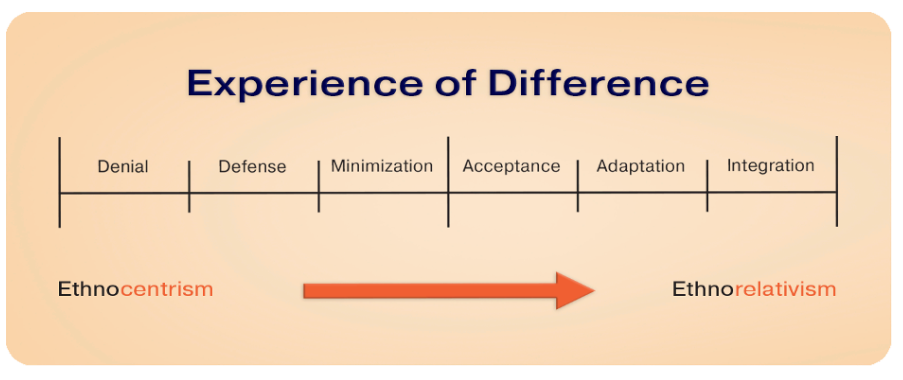

Figure 2: The Developmental Model of Intercultural Sensitivity

The stages of denial, defence, minimization, acceptance, adaptation, and integration make up the continuum and predict a person's journey towards intercultural competency. Along the continuum, the perceptions and experiences of difference 
become more and more complex until we can experience another's culture with the same amount of complexity as our own.

As its name suggests, the Developmental Model of Intercultural Sensitivity develops an individual's ability to have a more complex experience of otherness and constitutes what Bennett termed "intercultural sensitivity." Intercultural competence is this ability to make meaning in other cultural contexts as comfortably as we do in our own culture.

\section{Introduction to Bennett's Developmental Model of Intercultural Sensitivity (Video)}

Dally, J. (2013, September 28). Bennett's Developmental Model of Intercultural Sensitivity (DMIS) [Video]. YouTube. https://youtu.be/6vKRFH2Wm6Y

\section{Stages of Developmental Model of Intercultural Sensitivity (DMIS )}

\section{Ethnocentric Stages of Development}

(Summarized from Bennett, 2004, pp. 62-72; Bennett, 2017, pp. 3-5) 


\section{Ethnorelative Stages of Development}

An interactive H5P element has been excluded from this version
of the text. You can view it online here:
https://openeducationalberta.ca/settlement/?p=134\#h5p-10

(Summarized from Bennett, 2004, pp. 62-72; Bennett, 2017, pp. 3-5)

\section{A Few Important Final Notes on the DMIS}

It would be incorrect to assume that those who are more interculturally sensitive are better people (Bennett, 2004, p. 9). The model describes not what it means to be a good person, but what it means to be good at navigating differences and good at intercultural relations.

It is also important to note that the DMIS is not a model of required knowledge, attitudes, or skills. Any changes in knowledge, attitudes, or skills are considered reflections of changes in a person's expanding worldview.

The DMIS is about having a mindset that allows you to use the cultural knowledge and skills you have gained (or are gaining). Having cultural knowledge and skills without an ethnorelative worldview that enables you to use them appropriately is of little use. The DMIS describes how a person's mindset shifts, allowing them to have greater intercultural sensitivity, and as a result, greater intercultural competence.

"All we can say about more ethnorelative people is that they are better at experiencing cultural differences than are more ethnocentric people, and therefore, they are probably better at adapting to those differences in interaction. Perhaps you believe, as I do, that the world would be a better place if more people were ethnorelative" (Bennett, 2004, p. 9).

\section{Learning Activity 5: DMIS Self-Assessment}


1. Recall the descriptions of the DMIS stages. Read through the statements below that could be representative of an individual at each stage. Keep in mind that each stage reflects our experience of difference. Being at a higher stage does not mean you are a better person, just as being at a lower stage does not mean you are a lesser person.

2. Do you see yourself in any of the statements? Check off statements that apply or sound like you. What is it about these statements that makes you see yourself?

3. Look to see where most of your checked statements are. Where would you place yourself on the continuum?

An interactive H5P element has been excluded from this version of the text. You can view it online here:

https://openeducationalberta.ca/settlement/?p=134\#h5p-4

Adapted from Bennett, M. J. (1993). A developmental model of intercultural sensitivity. https://www.idrinstitute.org/wp-content/ uploads/2018/02/

FILE_Documento_Bennett_DMIS_12pp_quotes_rev_2011.pdf

\section{Using Intercultural Tools to Interpret Miscommunications}

When a conversation or communication does not go as we anticipated, we naturally try to understand why by looking at that situation through our own lens. We apply 
our past personal experiences and knowledge to make sense of what happened. The problem lies in just that-the assumptions we make based on our own cultural experiences and knowledge.

The D.I.E. Model is helpful for identifying why we are responding in this way and guides us toward a more thorough understanding of a miscommunication from another person's perspective.

There are three steps:

1. Describe what happened. We are encouraged to focus on the observable facts of the incident.

2. Interpret what happened. This is our interpretation and what we think about the event. It is vital to notice what emotions are present and how we might be personalizing the incident.

3. Evaluate what happened. We are encouraged to consider how we feel (whether positive or negative) about the incident.

Describe - Interpret - Evaluate

Description: What I see (only observed facts)

Interpretation: What I think about what I see

Evaluation: How I feel about what I see (positive or negative)

\section{Applying the D.I.E. Model}

Here is an example of how you might apply the D.I.E. Model to a typical settlement work scenario. 


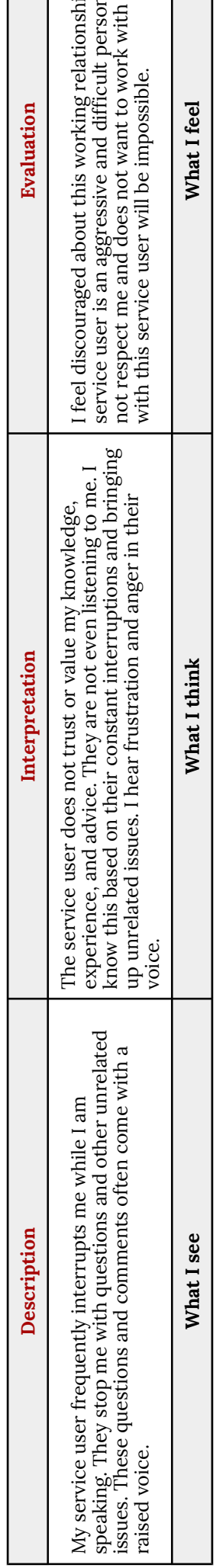


After working through the three steps, we consider some alternative explanations for the other person's behaviour. The alternatives need only be possible; they do not need to be correct. This model prompts one to reserve judgement and seek an alternative understanding of the behaviour of others.

Some alternative explanations for this scenario include the following:

- The service user may come from a culture with different conversational patterns or rules for interrupting.

- The service user may come from a culture that does not have a linear thinking and communication style.

- The service user may come from a culture with a communication style that values expressiveness and conveys emotion.

- A raised voice may indicate excitement and passion rather than anger.

Learning Activity 6: Reflection

What other explanations of this scenario could be included? 


\title{
Expanding Cultural Knowledge with Culture General Frameworks
}

\author{
What is the Difference Between a Stereotype and a \\ Generalization?
}

A generalization is a cultural pattern that helps us to understand a culture (Ross, 2011). When we apply a pattern to a whole group as a rule and assume it must be true of everyone, it becomes a stereotype. Use generalizations not to assume, but to ask the right questions.

\section{Cultural Generalizations}

It is arguably impossible and quite unrealistic to become an expert in many different cultures. This is where culture generalizations and culture general frameworks can come in.

Developed by anthropologists and other experts in communication, these frameworks can give us an understanding of the big picture and identify some possible areas of difference between two cultures (Bennett, 2001, p.4). For shorter interactions, this sometimes can be enough to help avoid obvious misunderstandings. They can call attention to the most important differences that must first be considered when encountering someone of a different culture.

However, keep in mind that these frameworks are meant to be used as a starting point. Notably, the frameworks consist of generalizations that will not apply equally to every group member, even though they may help predict possible differences and when potential misunderstandings can arise. Consider the frameworks a hypothesis to be continually tested and verified on an ongoing basis. 


\section{Cultural Generalizations in Communication}

\section{Reflect on the following questions:}

- How do you typically greet a friend? A co-worker? A service user?

- How do you know when it is your turn to speak in a conversation?

- How do you show interest in a conversation?

- How do you indicate understanding?

\section{Language Use}

The first notable cultural difference in communication is language. This has little to do with the language(s) we speak, but it is more about how language is used. Although differences may be subtle, they can be substantial. Language communicates greetings and identifies how turns are taken, how we interrupt, how we argue, how we criticize, and how we compliment one another (Bennett, 1998, p. 10).

For example, Meyer (2014) notes how silence can be a curious component of language use. Silence can indicate different things to different people; it could be indicative of irritation or misunderstanding. Americans are typically comfortable with two to three seconds of silence; in general, Americans have a "ping-pong" style of conversation and are not comfortable with either overlap or silence. On the other hand, Chinese people are comfortable with seven to eight seconds of silence. Therefore, from an American person's perspective, the prolonged silence of a Chinese person might be assumed to mean they have nothing to add to the conversation. Conversely, the Chinese speaker may have difficulty adding to a conversation because they typically wait for a more extended period of silence before contributing and feel they cannot "jump" into the conversation. 


\section{Non-Verbal Behaviour}

Differences in non-verbal behaviour refer to the use of voice (tone, pitch, etc.) and body language (facial expressions, gestures, distance or touch in communication). Like language use, these differences are generally unconscious and can be challenging to notice and explain.

As an example of non-verbal behaviour, we can talk about eye contact. As with language use, eye contact indicates turn-taking (Bennett, 2001, p. 6). For example, Americans tend to make medium-length eye contact before looking away. A longer, direct gaze indicates a desire for a change of speaker. In contrast, in some northern European countries such as the Netherlands or Germany, speakers use more prolonged and more direct eye contact and look away to indicate a change of speaker.

Americans tend to interpret prolonged eye contact as aggressive, whereas Germans tend to interpret weak eye contact as lack of interest. This might lead a German to intensify eye contact and an American to reduce eye contact to lessen the perceived threat. Both parties are thus left feeling that the other was trying to dominate the conversation.

In addition, the meaning of eye contact differs from culture to culture. In North America, sustained eye contact typically indicates attentiveness and that the listener is engaged in the speech. Lack of eye contact could indicate disinterest, boredom, or, at worst, dishonesty in speech. In many Asian cultures, however, direct eye contact is considered disrespectful.

\section{Communication Styles}

\section{Video - Low Context vs. High Context Societies - Erin Meyer (4:05)}

The Lavin Agency Speakers Bureau. (2014, May 9). Leadership speaker Erin Meyer: Low context vs. high context societies [Video]. YouTube. https://youtu.be/9oYfhTC91IQ 
Edward T. Hall (1976) is credited with observing and then coining the terms "high context" and "low context" communication styles.

High context cultures take significant meaning from the context or situation at hand rather than what is actually said (Bennett, 2001; Meyer, 2014). There is much "reading between the lines" that occurs, despite what is said or not said. Speakers in high context cultures tend to assume a large body of shared references. Communication is implicit, layered, nuanced, and sophisticated. In other words, it is not what is said but what is meant. In high context cultures, the listener does much of the work to decipher the message.

On the other hand, low context cultures pay little attention to the context but focus instead on what is directly communicated to make meaning. Communication in low context cultures tends to be explicit, simple, and straightforward. North American-style presentations are a fitting example of low context communication (Meyer, 2014). Students are taught a structured format for presentations from a young age that includes an introduction, body, and conclusion. The speaker starts by telling you what they will tell you. Then they tell you. And then they conclude by telling you what they told you. This exemplifies how in low context cultures the responsibility is on the speaker to ensure that the meaning of their message is communicated clearly.

Although speakers from high context and low context cultures can be talkative or quieter, the real difference is in how meaning is made. Many Western countries, like Canada, are more low context. On the other end of the spectrum, many African and Asian countries are high context.

As might be expected, differences in this particular communication style can result in considerable misunderstandings and miscommunications. As Meyer (2014) explained, low context people may perceive high context people as being secretive and lacking transparency. In contrast, high context people might believe that their intelligence is being insulted and may feel condescension.

When working with low context people, try to be as explicit as possible by putting things into writing and repeating key points. When working with a high context person, try to avoid repetition but instead ask questions to clarify as needed. Work on your ability to "read between the lines."

As a settlement worker, you may find someone from a high context culture less likely to make a direct request for what they need. An individual from a high context culture could also become somewhat frustrated by another's inability to "read the air" and perceived thoughtlessness. 


\section{Cultural Values}

\section{Hofstede's 6 Dimensions Model of National Culture}

Culture value frameworks are among the more abstract of the culture general concepts. Although numerous frameworks have been developed over time, Hofstede's Model of National Culture $(1980,2010)$ remains one of the best-known intercultural frameworks to date and has inspired many other frameworks since its inception in 1980.

Between 1967 and 1973, Professor Geert Hofstede surveyed IBM employees in more than 70 countries about their values and preferences in life (Bennett, 1998, p. 43). From this research, Hofstede created a model that initially included four dimensions of national culture-power distance, individualism, masculinity, and uncertainty avoidance. Hofstede's model ranks and scores countries on each of the dimensions. With subsequent research, the value dimensions of long-term orientation and indulgence were later added. Hofstede listed cultural dimensions for 76 countries based on replicating and extending his original IBM study, which has subsequently been completed on various international populations and by other scholars.

Many contemporary studies of cultural values now, at least in part, use Hofstede's categories. As with other culture general frameworks, Hofstede's model contains cultural generalizations that cannot be assumed to apply to all individuals. In fact, differences between two individuals within a country's culture could be just as significant as those between two individuals from two different countries. Furthermore, Hofstede's dimensions are meant to be used as a point of comparison because scores are relative and only hold meaning when compared to another country's scores.

What follows is a brief description of each of Hofstede's six cultural dimensions. An interactive H5P element has been excluded from this version
of the text. You can view it online here:

https://openeducationalberta.ca/settlement/?p=134\#h5p-8

Adapted from Hofstede, G. (n.d.). The 6-D Model of national culture. https://geerthofstede.com/culture-geert-hofstede-gert-jan-hofstede/6d-model-ofnational-culture/ 
Culture general frameworks are always cultural generalizations. Every individual is unique. Plot yourself on a continuum for each of the six dimensions. How might your preferences affect your working relationships?

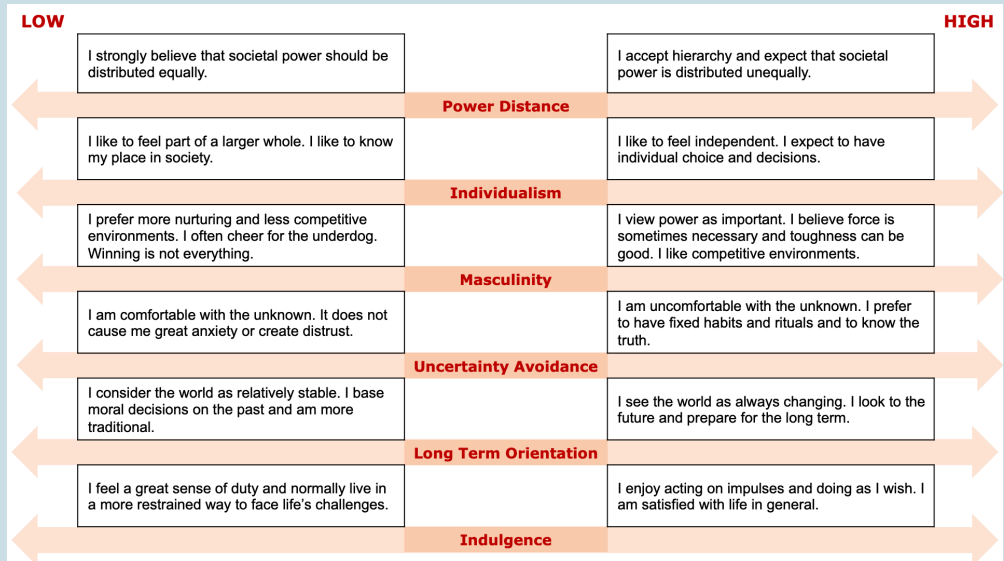

Learning Activity 8: Try It Out - Hofstede's Dimensions of National Culture

Choose a country of origin for a selected group of settlement service users you expect to work with in the future.

Go to Hofstede Insights: Country Comparison website

Compare that country to Canada on the six dimensions of national culture. 
- Based on your self-reflection, are there cultural dimensions where your preference differs from the Canadian cultural profile?

- In what dimensions did the country you chose differ most from Canada?

- How do you expect these differences to affect a working relationship you would have with this service user?

- How can this help you be a more effective settlement professional?

Learning Activity 9: Apply your Knowledge - Using the D.I.E. Model and General Cultural Knowledge

Think about a possible cultural miscommunication from your personal experience. Can you apply the D.I.E. Model to understand what happened from a different perspective? Consider what we have discussed about culture general frameworks (e.g., language use, non-verbal behaviour, communication styles).

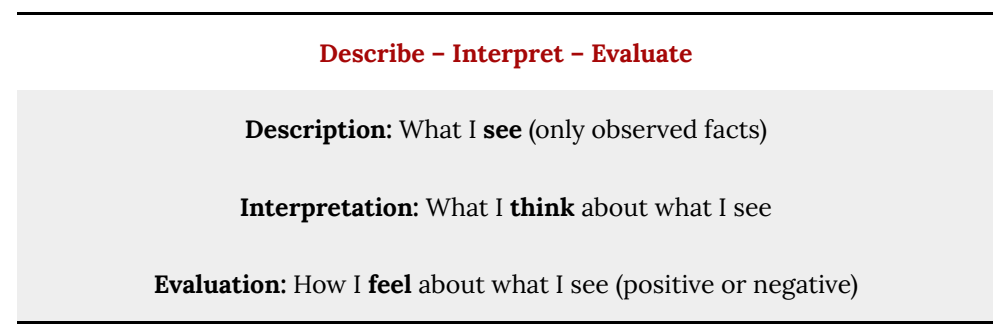

Copy the chart below into your textbook journal and complete the chart for the miscommunication from your personal experience. 
- What are the facts of what happened?

- How did you interpret this incident?

- How did this incident make you feel? 


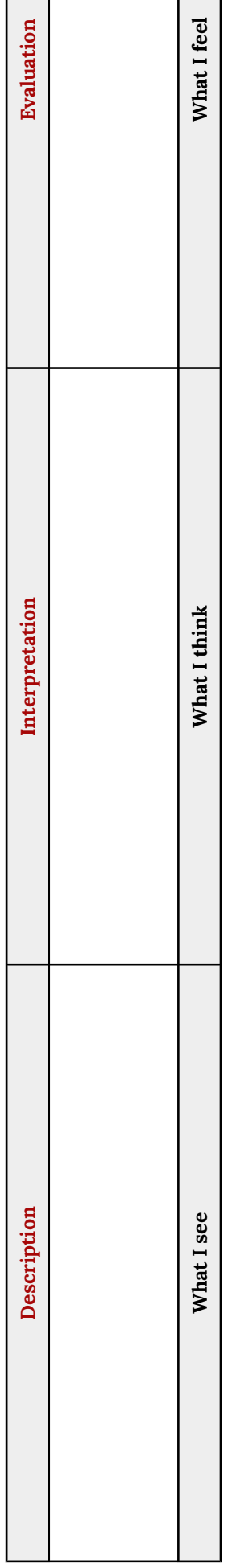




\section{A Process Model for Improving Our Intercultural Competence}

In this chapter, we began by defining our idea of culture. We continued to explore our own cultures and how our life experiences have shaped our assumptions and beliefs. Our journey of self-awareness continued by examining how we personally see and understand difference through the DMIS. We added to our cultural knowledge through an introduction to some culture general frameworks. We added a tool to our intercultural toolbox with the D.I.E. Model. The work we have done up until now (and will continue to do in the future) can be framed within Deardorff's Process Model of Intercultural Competence.

Deardorff's model illustrates how intercultural competence begins at an individual level with an attitude of respect, openness, curiosity, and discovery (Deardorff, 2015, pp. 140-142). These prerequisite attitudes involve valuing other cultures, withholding judgement, and having the ability to tolerate ambiguity. With these attitudes, an individual can deepen their cultural self-awareness and broaden their objective and subjective cultural knowledge. Skills like listening, observing, evaluating, analyzing, interpreting, and relating to others with diverse worldviews use these acquired attitudes and knowledge. Intercultural competence results when these attitudes, knowledge, and skills are applied, and the outcomes may be internal or external. An internal outcome is what happens within an individual. It is marked by a shift in their frame of reference and means that an individual can adapt an ethnorelative view and demonstrate adaptability, flexibility, and empathy. An external outcome is observed in the individual's intercultural interactions and is marked by an ability to interact effectively and appropriately in differing contexts or demonstrate successful intercultural competence.

\section{Deardorff's Process of Intercultural Competence}

Review Deardorff's Process Model of Intercultural Competence on page 143 of the article "21st Century Imperative: Integrating Intercultural Competence." As we have learned, intercultural competence is a lifelong and continuing process. As we work, travel, and live in multicultural communities, we will constantly meet and interact with unique members of diverse cultural communities. Because intercultural competence does not develop without intention, let us look to the future and make a plan for continuing development of these competencies. 


\section{Making an Intercultural Competence Development Action Plan}

As has been discussed, the process of developing intercultural competence is personal, reflective, and requires considerable effort and time. An intercultural competence development action plan can help focus our activities to meet this goal. As with most goals, having a timeline will help keep you on track. Consider how much time you can reasonably commit to this work on a weekly or monthly basis. An effective action plan will include activities that best suit how you like to learn, your interests, and your future goals.

When choosing intercultural exploratory activities, think back to your identity wheel. Are there parts of your cultural identity you want to explore further? Think about the different cultural groups that make up your community. Remember that cultural groups can be based on race, gender, sexuality, religion, or other traits. Are there any noticeable points of intercultural stress for you between your own culture and a different culture? Can you identify any gaps in your cultural knowledge?

Here is a short list of intercultural exploratory activities to inspire your intercultural development plan:

- Keep learning. Sign up for an educational course, workshop, lecture, or webinar that focuses on intercultural communication or related cultural topics of interest.

- Consider the arts. Watch a film or documentary. Attend an art exhibit or performance. Listen to music from different cultures. Be present at post-event discussions to explore the concepts presented and deepen your learning experience.

- Create a reading list. Select books, blogs, or articles related to social justice, race, class, gender, or ethnicity. Select works by authors with backgrounds different from your own. Select books that relate to past, current, or future intercultural settings that you have or will have. Books can be fiction or nonfiction. Many works of fiction 
can provide insights into the history and cultural norms of culturally diverse groups.

- Travel with intention either abroad or to communities different from your own. Visit places of cultural importance to different communities, such as historical sites and museums. When travelling, make an effort to experience how people from that cultural community live, interact, and relate with others.

- Participate in diversity and inclusion efforts in your workplace. Join employee resource groups and volunteer for work-related responsibilities that involve cultural bridging.

- Create an intercultural journal to reflect on your experiences and daily interactions with others. Focus on cultural similarities and differences that you notice in these interactions. Challenge yourself to focus on situations you have observed or participated in where you and others needed to understand cultural differences to respond appropriately.

Keep in mind that simply participating in activities alone is not enough to expand your intercultural competence. It is the thoughtful and intentional reflection on these cultural experiences that truly promotes development and growth. Use the learning opportunities to increase your cultural self-awareness as well as to acquire knowledge about different cultural perspectives.

Be curious. Put yourself in situations where you will meet others of different cultures. Listen to people's stories. Ask questions about their cultural practices, customs, and worldviews. 


\section{Supporting Clients to Develop Intercultural Competence}

Developing intercultural competence allows a person to communicate with others more effectively and appropriately in differing cultural settings. That said, although we cannot necessarily improve the intercultural competence of another person, we can use these concepts to better support service users and better understand someone else's experience.

According to Bennett (2001), the general rule is "Whoever knows the most about the other culture does the most adapting" rather than "Whoever has the power to impose their culture, does" (p. 8). Therefore, it is on the settlement professional to adapt and navigate gaps as best they can.

A few suggestions for bridging intercultural gaps while working with a service user:

- Share openly and honestly about your experiences and journey of intercultural competence.

- Have conversations about cultural differences. Encourage the service user to reflect on their own identity and culture.

- Learn from individual service users about their culture and cultural preferences.

- Do your homework. Keep adding to your culture-specific knowledge while testing cultural generalizations.

- Help the service user learn about cultural differences relevant for successful integration by providing insights.

- Whenever possible, explain the "why" behind what you are doing or saying. It may help the service user to view a behaviour from another cultural lens and mitigate miscommunications and misunderstandings. It could look like this: "In Canada, we often do or say $x$ because of $y$."

- When appropriate, gently and without judgement 
draw attention to behaviours that might cause issues in Canada because of cultural differences. Explain how that behaviour might be interpreted in Canada. It could look like this: "In Canada, when someone says or does $x$, it might be interpreted as $y$."

- Remember to be patient, flexible, and adaptable.

As a settlement worker, what specific strategies might you use to bridge intercultural gaps with service users?

\section{Review Activities - DMIS Stages}

\section{Key Characteristics Activity}

Drag and drop to label stages based on a key descriptor. 


\section{Challenge Tasks Activity}

Drag and drop to label stages based on a challenge task.

An interactive H5P element has been excluded from this version

뭇 of the text. You can view it online here:

https://openeducationalberta.ca/settlement/?p=134\#h5p-13

Reflection

Consider the DMIS stages and the challenge for each of the following:

- What kind of challenges might a service user in denial have when settling in Canada? What strategies could you use to support them?

- What kind of challenges might a service user in defence have when settling in Canada? What strategies could you use to support them?

- What kind of challenges might a service user in minimization have when settling in Canada? What strategies could you use to support them?

Image Credits (images are listed in order of appearance)

Bennett, M. J. (2014). A developmental approach to training for intercultural sensitivity. https://www.idrinstitute.org/dmis/

286 | Improving Intercultural Competence 
Self-Awareness Activity chart has been adapted from information on the following webpage: The 6-D model of national culture, by G. Hofstede, n.d. https://geerthofstede.com/culture-geert-hofstede-gert-jan-hofstede/6d-model-ofnational-culture/ 


\section{Summary}

In this chapter, we began by discussing what culture and intercultural competence are. We looked at the Developmental Model of Intercultural Sensitivity (DMIS) as a way of developing intercultural competence and supporting increasing self-awareness. We expanded our cultural knowledge with an introduction to some common culture general frameworks. We applied the D.I.E. Model to help us see a miscommunication from another perspective. We learned that intercultural competence is an intentional and continuous process, so we created an action plan to support future development.

Key Takeaways

- Being interculturally competent is the personal ability to interact with others effectively and appropriately in varying cultural contexts.

- Intercultural competence must begin with an awareness of our own cultural identities and lenses.

- Intercultural competence is not a just skill to be attained but requires a shift of mindset or worldview.

- Developing and maintaining intercultural competence is an intentional and lifelong learning process.

- Although we cannot improve the intercultural competence of others, being aware of the stages can help better understand, support, and show empathy for others. 


\section{Optional Readings and Resources}

\section{Optional Readings}

Bennett, J. M. (Ed.). (2015). The SAGE encyclopedia of intercultural competence. SAGE Publications.

Deardorff, D. K. (Ed.), (2009). The SAGE handbook of intercultural competence. SAGE Publications.

Hall, E. T. (1976). Beyond culture. Anchor Books Doubleday.

Hall, E. T. (1966). The hidden dimension. Anchor Books Doubleday.

Hall, E. T. (1959). The silent language. Anchor Books Doubleday.

Hofstede, G., Hofstede, G. J., \& Minkov, M. (2010). Cultures and organizations: Software of the mind. McGraw Hill.

Landis, D., Bennett, J. M., \& Bennett, M. J. (Ed.) (2004). Handbook of intercultural training (3rd ed.). SAGE Publications.

Meyer, E. (2014). The culture map: Breaking through the invisible boundaries of global business. Public Affairs.

Ting-Toomey, S., \& Tenzin, D. (2018). Communicating across cultures. Guilford Press.

*If you are interested in understanding one particular culture, the Intercultural Press website has resources.

\section{Further Tools for Assessing Intercultural Competence and Communication}

\section{Intercultural Development Inventory (I.D.I.)}

The Roadmap to Intercultural Competence Using the I.D.I.: https://idiinventory.com/ Intercultural Development Inventory (IDI) Handout (NorQuest College)

- Click to download a copy 
- Shared with permission from the NorQuest Centre for Intercultural Education

\section{Websites}

Norquest College Colbourne Institute for Inclusive Leadership

Intercultural Development Research Institute

\section{Geert Hofstede's Model of National Culture}

- The site includes 10-minute video explanations of each dimension and maps that compare countries on each dimension.

T.E.D. Playlist - Bridging Cultural Differences (9 talks)

- Nine talks that explore perspective-looking past the stereotypes to build new cultural understandings and learning who people are, what they do, and why they do it. 


\section{Chapter References and Attributions}

\section{References}

Bennett, J. M. (2014). Intercultural competence: Vital perspectives for diversity and inclusion. In Diversity at work: The practice of inclusion (pp. 155-176). Wiley/JosseyBass.

Bennett, J. M. (2009). Cultivating intercultural competence: A process perspective. In D. K. Deardorff (Ed.), The SAGE handbook of intercultural competence (pp. 121-140). Sage.

Bennett, M. J. (2017). Development model of intercultural sensitivity. In Y. Kim (Ed.), International encyclopedia of intercultural communication. Wiley.

Bennett, M. J. (2004). Becoming interculturally competent. In J. S. Wurzel (Ed.), Toward multiculturalism: A reader in multicultural education (pp. 147-165). Intercultural Resource Corporation.

Bennett, M. J. (2001). Intercultural competence for global leadership. The Intercultural Development Research Institute. https://www.idrinstitute.org/wp-content/ uploads/2018/02/Global_ICC_IDRI.pdf

Bennett, M. J. (1998). Intercultural communication: A current perspective. In Milton J. Bennett (Ed.), Basic concepts of intercultural communication: Selected readings (pp. 1-20). Intercultural Press.

Cole, S. (Ed.). (2017). Developing your Intercultural Development Plan (IDP). Diversity, Equity and Inclusion. https://www.berea.edu/diversity-and-inclusion/developingintercultural-development-plan-idp/

Deardorff, D. K. (2015). A 21st century imperative: Integrating intercultural competence in tuning. Tuning Journal for Higher Education,3(1), 137-147. https://tuningjournal.org/article/view/765/1081

Fearon, J. D. (1999). What is identity (as we now use the word). Unpublished manuscript, Stanford University.

Hall, E. T. (1976). Beyond Culture. Doubleday.

Hofstede, G. (2001). Culture's consequences: Comparing values, behaviors, institutions and organizations across nations. Sage. 
Hofstede, G. (n.d.). The 6-D model of national culture. https://geerthofstede.com/ culture-geert-hofstede-gert-jan-hofstede/6d-model-of-national-culture/

Hofstede, G., Hofstede, G. J., \& Minkov, M. (2005). Cultures and organizations: Software of the mind (Vol. 2). McGraw-Hill.

Hofstede Insights. (2021). Country comparison. https://www.hofstede-insights.com/ country-comparison/

Meyer, E. (2014). The culture map. Public Affairs.

Norton, B. (1997). Language, identity, and the ownership of English. TESOL Quarterly, 31(3), 409-429.

Schaetti, B. F. (2000). Global nomad identity: Hypothesizing a developmental model. The Union Institute.

Schneider, S., \& Heinecke, L. (2019). The need to transform science communication from being multicultural via cross-cultural to intercultural. Advances in Geosciences, 46, 11-19. DOI: $\underline{10.5194 / \text { adgeo-46-11-2019 }}$

Schriefer, P. (2016, April 18). What's the difference between multicultural, intercultural, and cross-cultural communication? Spring Institute. https://springinstitute.org/ whats-difference-multicultural-intercultural-cross-cultural-communication/

\section{Media Attributions}

CookRossinc. (2011, January 26). Overcoming cultural stereotypes [Video]. YouTube. https://www.youtube.com/watch?app=desktop\&v=MDw68BQxKEk

Dally, J. (2013, September 28). Bennett's Developmental Model of Intercultural Sensitivity (DMIS) [Video]. YouTube. $\quad$ https://www.youtube.com/ watch?app $=$ desktop\&v=6vKRFH2Wm6Y\&feature $=$ youtu.be

GCPE BCGov. (2016, April 20). Cultural iceberg [Video]. YouTube. https://www.youtube.com/watch?v=woP0v-2nJCU\&ab_channel=GCPEBCGov

The Lavin Agency Speakers Bureau. (2014, May 9). Leadership speaker Erin Meyer: Low context vs. high context societies [Video]. YouTube. https://www.youtube.com/ watch?v=9oYfhTC91IQ\&ab channel=TheLavinAgencySpeakersBureau

Mason, N. (2017, November 28). The Culture Map - Erin Meyer [Video]. YouTube. https://www.youtube.com/watch?v=7lzpYQFdkc\&list=PLPulR4Kq63KREjGxCe2D7kVvfNkP-snG9\&index=4 


\section{CHAPTER 6: GENDER, SEXUALITY, AND CULTURE}





\title{
Introduction
}

\author{
LYNN SUTANKAYO
}

\section{Situating Ourselves}

In this chapter, we examine the ways we see gender through a lens that can be applied to the settlement sector to promote dignity for all people. The text introduces concepts for learners new to the fields of gender studies, settlement work, and community support work in Canada.

The examination of foundational concepts such as gender, gender inequality, and gender roles is necessary for learners to engage with the gender-based analyses and best practice research produced by the settlement sector. Moreover, the topic of gender in a global and local context is essential for learners to develop critical literacy skills to interpret their world and, for settlement workers, to provide genderresponsive support to newcomer communities.

Located in amiskwaciy-wâskahikan, I acknowledge that we are in traditional lands referred to as Treaty 6 Territory and the homeland of Metis Region \#4. As a secondgeneration immigrant, I am a settler and a Treaty person. I share this home with many diverse groups of Indigenous peoples who have called these lands home since time immemorial, meaning that I trace my ancestors back to other places in the world, whereas my Cree, Dene, Blackfoot, Saulteaux, Nakota Sioux, Inuit, and Métis friends trace lineage back to here. Applying a treaty sensibility (Donald, 2014), it is an ethical imperative for learners in settlement studies to reach their hands out in friendship to newcomers, with the reciprocal promise of respect for this land and its stewards, ecology, and spirit.

\section{"At first, I wondered why we were learning about gender in settlement studies. Now I get it." \\ - Settlement studies student}

To begin, consider the relationship between gender and immigration as described by the International Organization for Migration: 
Gender is central to any discussion of the causes and consequences of migration, whether forced, voluntary, or somewhere in between.

It is recognized that a person's sex, gender, gender identity, and sexual orientation shape every stage of the migration experience.

Gender influences reasons for migrating, who migrates and to where, how people migrate and the networks they use, opportunities and resources available at destinations, and relations with the country of origin. Risks, vulnerabilities, and needs are also shaped in large part by one's gender, and often vary drastically for different groups. The roles, expectations, relationships, and power dynamics associated with being a man, woman, boy, or girl, and whether one identifies as lesbian, gay, bisexual, transgender, and/or intersex (LGBTI), significantly affect all aspects of the migration process and can also be affected in new ways by migration (2022, para. 1-3).

Think about the migration stories you know from your own experiences and from the experiences of your family, friends, and the communities with which you work. How might gender have shaped their stories?

Specific Learning Outcomes

By the end of this chapter, you should be able to

1. Describe the relevance of gender analysis to settlement support and service

2. Define foundational concepts for learners new to the fields of gender studies and settlement studies

3. Examine the concept of gender equality in local and global contexts and its implications for settlement practice 


\section{Key Terms}

Understanding key terms can help demystify many perceptions associated with gender concepts. Becoming familiar with this vocabulary will facilitate learning in this chapter and, ideally, support you in engaging in conversations with diverse people. Keep in mind that language continues to evolve, and there can be many different ways to describe the same concept.

The list of key terms provided here is a small subset of a much larger set of genderrelated terminology (Donald, 2014; Department of Justice, 2022; Women and Gender Equality Canada, 2022a). 


\begin{tabular}{|c|c|}
\hline 2SLGBTQQIA & $\begin{array}{l}\text { Two-Spirit, lesbian, gay, bisexual, transgender, queer, } \\
\text { questioning, intersex and asexual (Egale Canada, n.d.) }\end{array}$ \\
\hline Binary & $\begin{array}{l}\text { A division into two groups that are considered distinct and } \\
\text { opposite }\end{array}$ \\
\hline Cisgender & $\begin{array}{l}\text { People whose gender identity matches the sex they were } \\
\text { assigned at birth }\end{array}$ \\
\hline Colonialism & $\begin{array}{l}\text { The policy of taking political and economic control of a territory } \\
\text { and the people who are Indigenous to that area; underpinned by } \\
\text { racist doctrines of superiority }\end{array}$ \\
\hline Colonization & $\begin{array}{l}\text { The action or process of settling and taking political and } \\
\text { economic control of a territory and the people who are } \\
\text { Indigenous to that area; underpinned by racist doctrines of } \\
\text { superiority }\end{array}$ \\
\hline Gendered & $\begin{array}{l}\text { Characteristic of, suited to, or biased toward or against a specific } \\
\text { gender }\end{array}$ \\
\hline Gender-diverse & $\begin{array}{l}\text { Individuals who do not identify as exclusively male or exclusively } \\
\text { female; for example, individuals who are non-binary or } \\
\text { Two-Spirit }\end{array}$ \\
\hline Gender expression & $\begin{array}{l}\text { The way in which people publicly present their gender through } \\
\text { aspects such as dress, hair, makeup, body language, and voice }\end{array}$ \\
\hline Gender identity & $\begin{array}{l}\text { A person's internal and deeply felt sense of being a man or } \\
\text { woman, both, or neither; a person's gender identity may or may } \\
\text { not align with the gender typically associated with their sex }\end{array}$ \\
\hline Heteronormativity & $\begin{array}{l}\text { A cultural or societal bias, often implicit, that assumes all people } \\
\text { are straight and so privileges heterosexuality and ignores or } \\
\text { underrepresents same-sex relationships (National Inquiry into } \\
\text { Missing and Murdered Indigenous Women and Girls, 2019) }\end{array}$ \\
\hline Heterosexism & $\begin{array}{l}\text { Prejudice and discrimination in favour of heterosexuality; } \\
\text { includes the presumption of heterosexuality as the superior and } \\
\text { more desirable form of attraction }\end{array}$ \\
\hline Heterosexual & $\begin{array}{l}\text { An individual sexually attracted to people of the opposite sex or } \\
\text { gender }\end{array}$ \\
\hline Indigenous identity & Individuals who identify as First Nations, Inuit, or Métis \\
\hline Intersectionality & $\begin{array}{l}\text { The interconnected nature of various social or identity factors, } \\
\text { such as sex, gender, age, race, ethnicity, Indigenous identity, } \\
\text { economic status, immigrant status, sexual orientation, disability, } \\
\text { and geography, as they apply to a given individual or group, } \\
\text { viewed as impacting experiences of discrimination or } \\
\text { disadvantage. For example, intersectionality recognizes that } \\
\text { Indigenous women hold more than one identity. They are women } \\
\text { and share some common experiences with other women, and } \\
\text { they are Indigenous and have shared experiences with Indigenous } \\
\text { men. Trying to understand Indigenous women's experiences by } \\
\text { focusing only on sex or only on Indigenous identity prevents us } \\
\text { from seeing how these identities intersect to create a unique } \\
\text { lived experience for Indigenous women that is different from the } \\
\text { experiences of Indigenous men and non-Indigenous women. }\end{array}$ \\
\hline Men & $\begin{array}{l}\text { All people who identify as men, whether they are cisgender or } \\
\text { transgender men }\end{array}$ \\
\hline
\end{tabular}




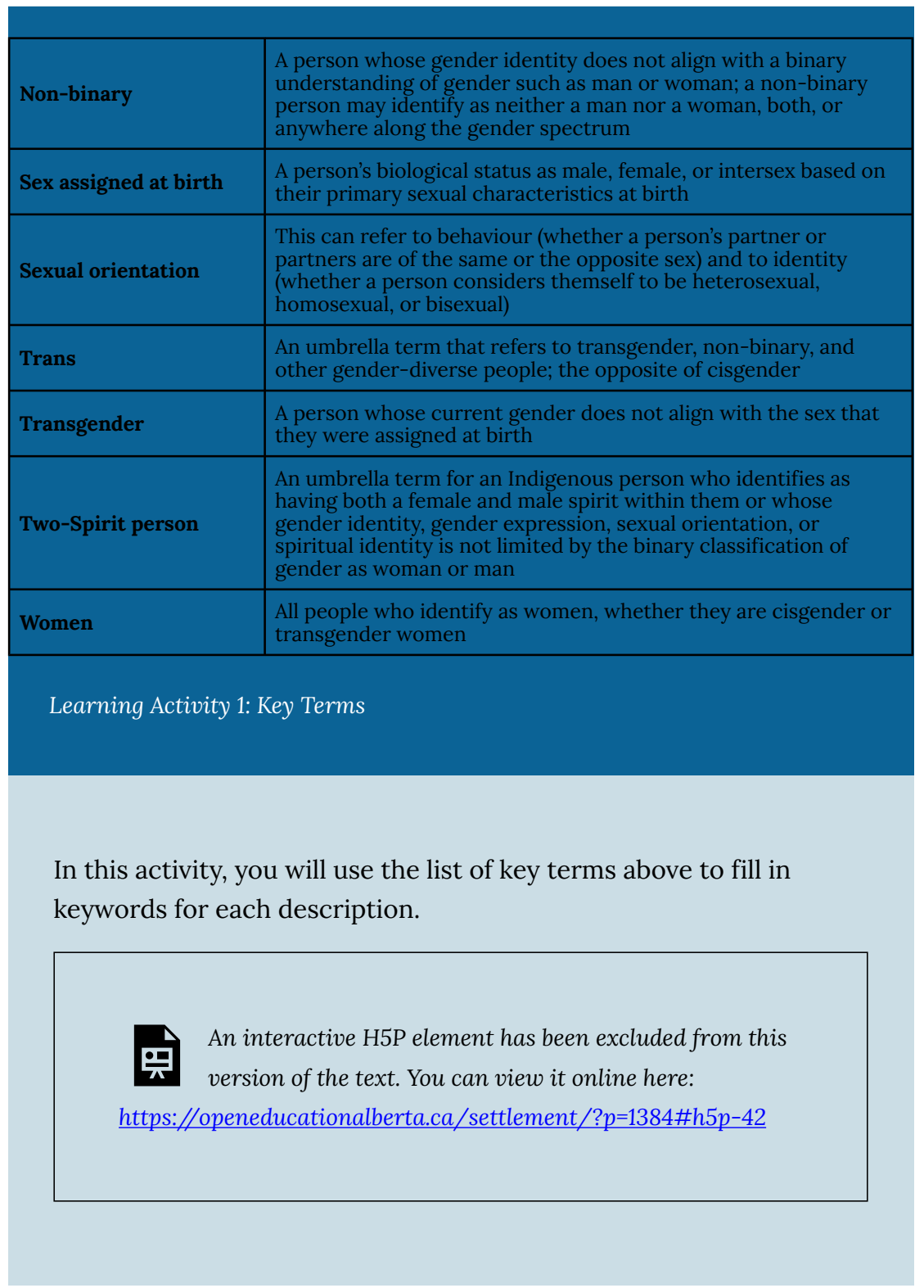




\section{Guiding Questions}

The Canadian Council for Refugees (CCR) poses an essential question to our field: How is gender analysis relevant to my work in the immigrant- and refugee-serving sector? Gender norms and values play roles in shaping Canadian immigration policy, the settlement experiences of newcomers, and the evolution of the settlement sector itself. A gender analysis approach requires a "lens" that illuminates the role of gender in shaping experiences along the settlement continuum (Desouza, 2007).

Despite its complex scope, settlement studies needn't look far to find reasoning for a focus on gender in both policy and practice. The summary findings from the Settlement Outcomes HIGHLIGHTS Report 2021 (IRCC, 2021c), by Immigration, Refugees and Citizenship Canada (IRCC), indicates gender as a significant factor among the key themes identified in its high-level research report:

Settlement programming design, such as when and where service delivery is provided, can have an impact on the ability of newcomer women to access services. Shortages in the availability of child care can have gendered effects, as women are greater users of child care. Data from the Immigration Contribution Agreement Reporting Environment (iCARE) show that, among women, a work placement was the most common form of long-term employment intervention (51\%) and $72 \%$ of these were unpaid, compared to $52 \%$ for men.

It is also important to note the difference in employment rates within the resettled refugee category: male respondents reported a much higher employment rate than female respondents (2021c, pp. 5-6).

The application of a gender analysis might begin with a central question to uncover the roots of these findings: How are the settlement experiences of men, women, and non-binary people different, and why? The IRCC states a need for Canada's settlement program to apply a focused gender lens to address barriers to integration. Both individuals and organizations can cultivate skills and knowledge to advance gender equality in recognition of its interdependence with positive settlement outcomes.

Learning Activity 2: Introduction to Gender Analysis 
The following scenarios (with images) are excerpted from pp. 2.1-2.2 of the Canadian Council for Refugees (CCR) Pathways to Gender Justice Toolkit (2006). As you review the scenarios, think about your answers to the following questions:

- See: Which story resonates most with you?

- Think: What kind of challenges will these individuals and families face?

- Wonder: What kinds of settlement services do we need to address these challenges?

- Look Ahead: What do you need to learn more about to answer these questions?

\section{Scenario 1}

A man who arrived in Canada three years ago with his children has been recovering from his wife's death. He has felt alone and at times suicidal, but he has kept on because of his love for his children, now aged four, seven, and eight. He speaks a little French and no English. His settlement counsellor has been trying to get him to attend a men's group in his first language, but he cannot afford a babysitter on his low income. Why is child

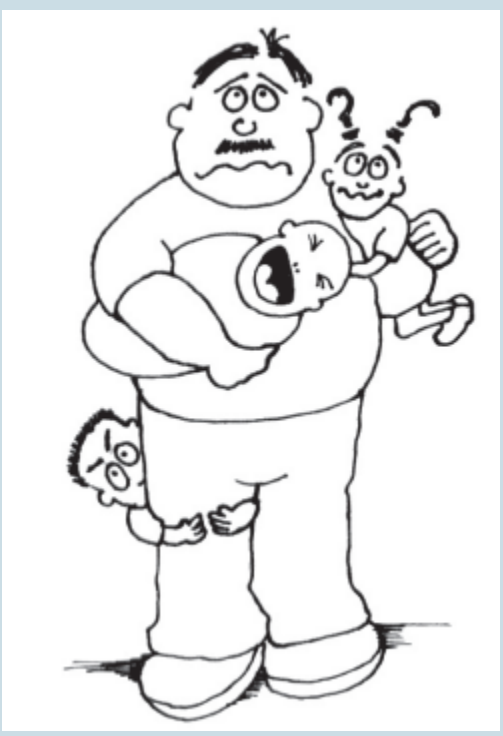
care not provided for immigrant men's groups? Consider the many reasons that a father who has immigrated to Canada needs access to child care.

\section{Scenario 2}




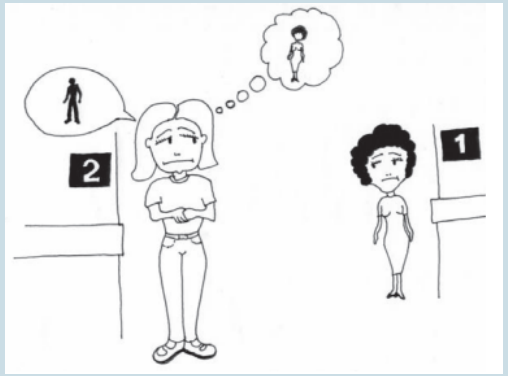

Two professional women who are life partners immigrate to Canada together on separate applications. They get an apartment together and take low-paying jobs that are not related to their educational and professional experience. They

have no family or friends in Canada but are sending money back to their home country to support their children and parents. They are having trouble keeping up with the cost of living in a Canadian city, and the stress starts to affect their health. When they visit a local community agency to ask for support, they are connected with separate social workers. The community agency and the social workers have assumed that they are single women who have never married and have no children. One social worker has asked one of the women if she is dating any men now that she has started to settle into her new life in Canada. The woman answers "no," but she does not know what will happen if she explains that she is living with her life partner. Consider how safe or unsafe it is for immigrants and refugees to disclose their sexual orientation to community agencies and therapeutic offices, and in immigrant- and refugee-serving sector encounters.

\section{Scenario 3}

A woman who has always been responsible for her family's finances flees persecution with her husband and children. They are resettled to Canada as government-assisted refugees. The husband is identified as the "head of household" and

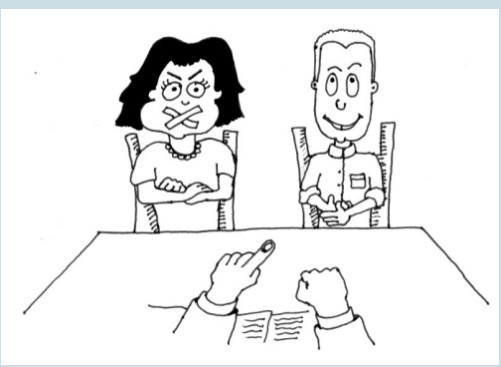
receives the income support cheque in his name. This results in tensions within the family. The man feels confused about what this 
new country expects of him. The woman feels that her role in the family is being taken away and that she is not valued in this new society. 


\section{Gender, Equality, and Justice}

Gender justice is a concept that typically refers to approaches that advance women's rights through legal change or other actions that promote the full participation of women in the economic, social, and political life of a nation or a community (Oxfam International, 2022b, para. 5; Goetz, 2007, p. 17). Gender justice seeks to extinguish longstanding patterns of violence, poverty, control, and discrimination experienced by women, gender-diverse people, and people who identify as 2SLGBTQQIA+. The term "gender justice" is often used interchangeably with notions of gender equality, gender equity, women's power, and women's rights (Goetz, 2007, p. 17). Gender justice priorities are unique to a population's location, identities, and proximities to decision makers and power. Gender justice is applicable to the lives of newcomers and to the settlement sector but may mean something different to various communities of people, based on their identities and experiences.

Historically, Western perspectives have set the prerogatives of gender justice globally, where international development discourse has been critiqued for its reproduction of a "saviour complex" in gender justice advocates. Post-colonial feminist theorist, Chandra Mohanty (1988), explains how Western scholarship has helped shape the misconception that women from the global south are a homogenous group of "Third World Women" who are unaware of their oppression and require charity from Western women, organizations, and other groups to rescue them. The stereotype is a woman who is, by Western standards, a victim of economic, religious, and family structures and is defined as religious, family-oriented, illiterate, and domestic (Mohanty, 1988, p. 65). This image, a sweeping generalization, contributes to the stigma facing immigrant women and to potential biases impacting settlement worker practices.

The danger of this disempowering stereotype is that it masks the diversity of experiences, identities, and socio-political situations of women, while at the same time painting a picture of victimhood that only serves to paralyze women (Tyagi, 2014, p. 49). Yet, women and people of diverse gender and 2SLGBTQQIA+ identities lead social change movements, scholarship, and other forms of resistance at the heart of gender justice, oftentimes helmed by the grassroots efforts of Indigenous peoples and so-called "Third World" communities.

For example, Little et al. (2020) document immigrant women's activism from the 1960s to the 1980s in Ontario and British Columbia, revealing nuanced priorities for gender justice in comparison to mainstream Western feminist movements of the time. For example, immigrant women's call for reproductive rights extended to advocacy for immigration policies that allowed for family reunification and parents' liberties to raise their children alongside them in Canada. Immigrant women also developed their own settlement service organizations and practices, informed by their lived 
experiences and often working in partnership with men to address issues such as domestic violence. Some groups of immigrant women also led grassroots ESL education, even developing ESL "survival kits," songs, radio soap operas, videos, and books for use in teaching, as well as political organizing tools (Little et al., 2020, p. 113). In the field of settlement work, the philosophy and action informing gender justice are contextualized by development discourse, feminist history, and Canadian systems, as well as newcomers' priorities based on their socio-political realities and lived experiences.

\section{Gender Equality and Gender Equity}

In this chapter, we will employ the term gender equality as used by Women and Gender Equality Canada, the federal department that plays a leadership role in the implementation of Gender-Based Analysis Plus (GBA+). The concept of gender equality must be understood in relation to the concept of gender equity. This distinction is described by Sarkar (2022) of the digital intersectional feminist media organization, Feminism in India: "Although gender equality is the ultimate goal, it is only through gender equity that it can be achieved" (para. 1).

Review the definitions of gender equality and gender equity below, as defined by Women and Gender Equality Canada:

Gender equality refers to equal rights, responsibilities, and opportunities for women, men, and non-binary people. Equality refers to the state of being equal, while equity refers to the state of being just, impartial, or fair. However, equality of opportunity by itself does not guarantee equal outcomes for women, men, and non-binary people (Government of Canada, 2022, Glossary).

Gender equity refers to fairness, impartiality, and justice in the distribution of benefits and responsibilities between women, men, and non-binary people. Unlike gender equality, which simply provides for equality of opportunity, gender equity explicitly recognizes and actively promotes measures to address historical and social disadvantages. By "levelling the playing field," gender equity creates circumstances through which gender equality can be achieved. Gender equity means providing all social actors with the means to take advantage of equality of opportunity (Government of Canada, 2022, Glossary). 
Learning Activity 3: Equity vs. Equality

An interactive H5P element has been excluded from this 믓 version of the text. You can view it online here: https://openeducationalberta.ca/settlement/?p=1392\#h5p-39

Images: Equity vs Equality by MPCA Photos is licensed under CC BY-NC 2.0 [text removed]

Find images on the internet that portray gender equality and gender equity. How do your images differ from each other? 


\section{Measuring Gender Equality}

Learning Activity 4: Gender Equality

\section{Personal Reflection and/or Group Discussion:}

On a scale of 1 to 10 , with 1 being "Not at all" and 10 being "Very much," how much does gender equality affect you?

Each year since 2006, the World Economic Forum has published a Global Gender Gap Report to gauge gender equality on a global scale. The report uses a framework to capture the different rates of social participation of men and women and tracks their progress over time. Annually, it measures women's participation in four areas: the economy, education, health, and politics. According to the 2021 report, the Global Gender Gap score of the 156 participating countries was $67.7 \%$. This means that the remaining gap to close stands at 32.3\% (World Economic Forum, 2021, p. 9). The "gap" refers to gender parity-that is, women and men's equal participation in education, health, politics, and the economy. The World Economic Forum projects that it will take 135.6 years to close the gender gap worldwide (p. 5). Several countries have seen improvements in their scores over time (Global Development Commons, n.d.), but most countries' scores dropped as a result of the COVID-19 pandemic, which disproportionately impacted women's employment, care burden, and safety from gender-based violence and human trafficking in Canada and around the world (Luna, 2021; Oxfam International, 2022a; Standing Committee on the Status of Women, 2021).

The frameworks underpinning such measures are subject to critique, particularly when the analysis demonstrates how Western Europe and North America are champions of gender equality in comparison to the regions ranked lowest, such as the Middle East and North Africa and South Asia (WEF, 2021, p. 20). Notwithstanding, the Gender Gap Report produces important data and stands for accountability to gender equality. In some aspects, it contradicts the "Third World Woman" stereotype by revealing that countries with lower GDPs than Canada can score a higher ranking; for example, Rwanda and Nicaragua. However, it can also mask other markers of inequality that are not measured through the report, such as gender-based violence 
against women or the experiences of gender-diverse and 2SLGBTQQIA+ people. Gender parity offers one measure of gender equality; however, reaching gender equality requires a wholesale approach, as we will see in the next section on

\section{Sustainable Development Goals (SDGs).}

Learning Activity 5: Global Gender Gap

1. Visit the World Economic Forum website to find the most recent Global Gender Gap Report

(https://www.weforum.org/reports/global-gender-gapreport-2021).

2. Find a country of interest to you-perhaps a country in which you have lived or have visited. What is the country's rank?

3. Find Canada's ranking. How do the rankings compare overall and in each of the areas of the economy, education, health, and politics?

4. How might a country's gender gap rank influence a settlement worker's perception of a client from that country?

\section{Gender Equality - A Global Goal}

The 17 Sustainable Development Goals (SDGs) were developed by the United Nations, where each member country has committed to their achievement. According to UN Women (2014a), sustainable development refers to "economic, social, and environmental development that ensures human well-being and dignity, ecological integrity, gender equality, and social justice, now and in the future" (p. 26).

The aim of the SDGs is to reach these goals by 2030 in order to fight global inequality, end extreme poverty, and respect our planet. The United Nations claims that all the goals can be achieved through solidarity and the mobilization of every person, urging multilevel action from government, civil society, and business on a global scale

Gender equality is central to the SDGs because it impacts each of the other 17 Global 
Goals, and the SDGs recognize the human impact of gender inequality. The plan to reach these goals is situated within development discourse, which is commonly critiqued for its focus on economic growth for the benefit of Western interests. Thus, gender equality is central to the SDGs because it improves economic growth and development. Notwithstanding, SDG Global Goal 5, to "Achieve gender equality and empower all women and girls," outlines important global targets:

\section{SDG 5: Gender Equality - Global Targets:}

5.1 End all forms of discrimination against all women and girls everywhere.

5.2 Eliminate all forms of violence against all women and girls in the public and private spheres, including trafficking and sexual and other types of exploitation.

5.3 Eliminate all harmful practices, such as child, early, and forced marriage and female genital mutilation.

5.4 Recognize and value unpaid care and domestic work through the provision of public services, infrastructure, and social protection policies and the promotion of shared responsibility within the household and the family as nationally appropriate.

5.5 Ensure women's full and effective participation and equal opportunities for leadership at all levels of decision making in political, economic, and public life.

5.6 Ensure universal access to sexual and reproductive health and reproductive rights as agreed in accordance with the Programme of Action of the International Conference on Population and Development and the Beijing Platform for Action and the outcome documents of their review conferences.

(United Nations, n.d.)

Learning Activity 6: SGD 5 - Global Targets and Examples

There are five global targets that United Nations is focusing on to increase gender equity worldwide. The targets are 5.1, 5.2, 5.3, 5.4, and 5.5 and are listed above. In this online activity, you will find 
statistics and examples illustrating these targets. Can you connect each target to its example in this online matching activity?

\section{Campaigning for Gender Equality}

The Sustainable Development Goals claim that if each person can move towards fixing inequities where they live, cumulatively, we can make a difference. Campaigning is a way to spread awareness about gender equality. A campaign is an action or a type of mobilization that occurs when people do something to encourage others to take action.

\section{Example of a Gender Equality Campaigner}

As a result of the outbreak of civil war in Syria in 2011, more than 6.6 million Syrians have been forced to flee their country since 2011, and another 6.7 million people remain internally displaced. At the age of 15, Muzoon Almellehan moved with her family to a refugee camp in Jordan for three years. At the camp, 40 girls in her class dropped out of school to get married at the age of 14 or 15. Muzoon went door to door to persuade parents to leave girls in refugee schools rather than using early marriage as a source of survival. She also tried to persuade children to remain in school to prevent child marriage. After immigrating to the United Kingdom as a refugee, she continued her advocacy, including returning to Jordan. She is a UNICEF Goodwill Ambassador (Mendos et al., 2020).

Learning Activity 7: Video: "I Believe in the Syrian Children"

Watch Muzoon Almellehan's video Educate a Girl, Spark Hope. Discussion: 
- Why does gender equality need a campaign?

- What is the relationship between settlement work and the SDGs?

\section{Mapping Sexual-Orientation Laws}

The International Lesbian, Gay, Bisexual, Trans, and Intersex Association (ILGA World) is a worldwide federation of 1801 member organizations from 168 countries that has been campaigning for lesbian, gay, bisexual, trans, and intersex (LGBTQI) rights since 1978. It is governed by a board with representatives of diverse LGBTQI people from around the world. Every year, ILGA World produces a State-Sponsored Homophobia Report covering core information on legislation affecting people on the basis of their sexual orientation and tracks changes within multiple countries over time (Mendos et al., 2020). ILGA World assigns overall scores to each region and on a global scale. This output can be useful for tracking the pace of change, both in terms of laws that criminalize and laws that protect people on the basis of sexual orientation. ILGA World states: "The number of "criminalising countries"-currently at 69-is considered to be among the global indicators of state-sponsored hostility against sexual diversity" (Mendos et al., 2020, p. 11). 


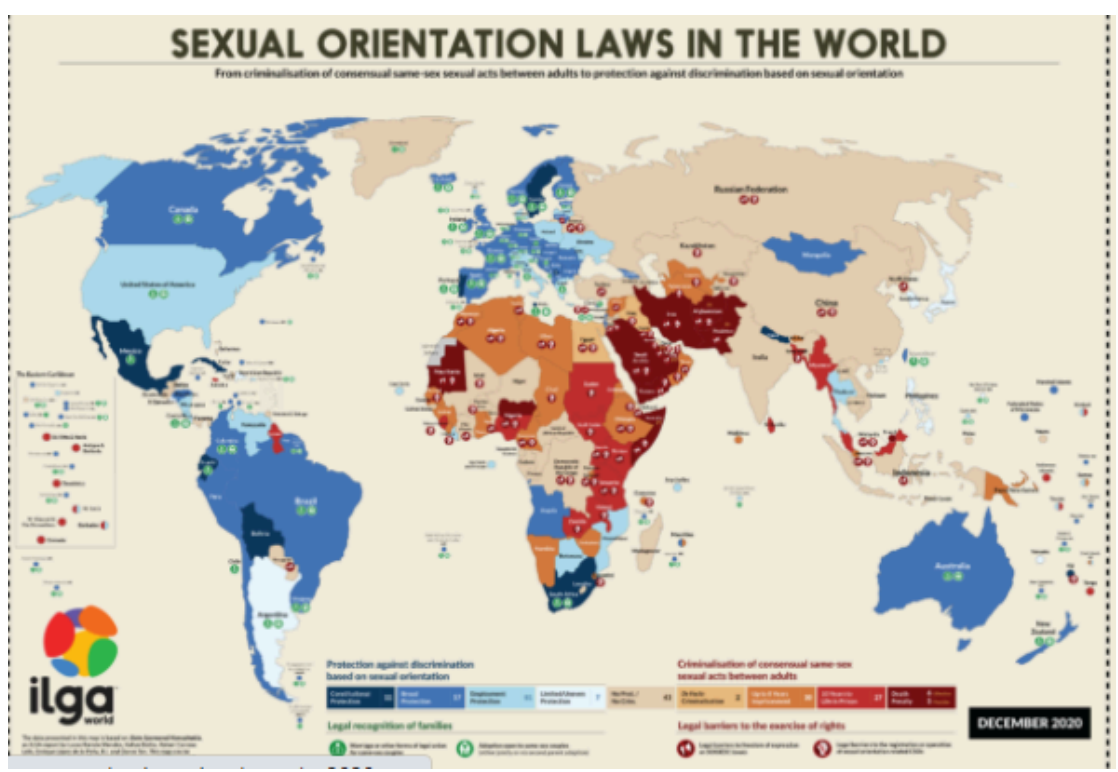

Image: ILGA World. (2020). 2020 map - Sexual orientation laws in the world. https://ilga.org/ map-sexual-orientation-laws-december-2020

ILGA World also publishes maps of sexual orientation laws in various countries that are translated into multiple languages for use all over the world. It addresses the limitations of its publications in that they do not cover in depth the legal issues related to gender identity, gender expression, or sex characteristics. It also recognizes that "the law then clearly paints only a partial picture of the situation in the countries we cover in this report .... How hostile or safe a country is cannot be derived exclusively from what said country's legal framework looks like" (Mendos et al., 2020, p. 9). ILGA World's reporting and mapping is relied upon by its readership, including members of civil society, social justice advocates, governmental and non-governmental stakeholders, and the United Nations (Mendos et al., 2020, p. 9).

Learning Activity 8: Sexual Orientation Laws in the World

1. Examine the most recent ILGA World Map of Sexual 
Orientation Laws in the World, and pay attention to the colour-coded legend depicting levels of criminalization and protection. Feel free to read the map in the language of your choice, as available.

2. Choose three countries where you have either lived or travelled.

3. For those countries, what is their status on criminalization or protection?

4. How do these laws reflect your lived experience of the country? Do these laws impact how easy or difficult it is for you to live or travel there?

5. Think back to the question posed earlier in the chapter: How much does gender equality affect you? After considering the ILGA World maps, has your answer changed?

Video: Watch Last Chance by Paul Émile d'Entremont, provided by the National Film Board of Canada

This National Film Board of Canada film follows the journeys of five individuals who leave their homelands to seek refugee status in Canada to escape homophobic violence. The viewer learns about their stories, reasons for leaving, and the steps they take to seek asylum in Canada. Warning: This film contains stories about graphic violence faced by the subjects of the documentary.

In July 2005, Canada became the fourth country in the world to legalize same-sex marriage nationwide (Parliament of Canada, n.d.). Canada is often considered to be a "safe" country for people of diverse gender and sexual identities. The settlement sector, as well as other community services, have built capacity in recent years to meet the unique settlement needs of LGBTQQIA+ immigrants and refugees, and continue to identify best practices to improve gaps in services. See the resources from provincial hub organizations listed below for further information:

- Affiliation of Multicultural Societies and Service Agencies, British Columbia (AMSSA)

- Settlement Challenges of Lesbian, Gay, Bisexual and Transgender (LGBT) Immigrants and Refugees 
- The Journey of LGBTQ Immigrants and Refugees in Canada (Video)

- Alberta Association of Immigrant Serving Agencies (AAISA)

- Story of Impact: Settlement Agencies In Alberta Blazing the Trail for LGBTQ+ Newcomers

- Ontario Council of Agencies Serving Immigrants (OCASI)

- Positive Spaces Initiative

\section{Canada's Gender and Immigrant Pay Gaps}

Have you ever considered how gender inequality affects your paycheque? According to Statistics Canada, in 2021, "the gender pay gap for full-time and part-time employees is 0.89 , which means women make 89 cents of every dollar men make" (Statistics Canada, 2022). The gender pay gap is worse for those who face multiple barriers, including racialized women, Indigenous women, and women with disabilities (Canadian Women's Foundation, 2022, para. 2).

"The gender pay gap refers to the difference in average earnings of people based on gender. It is a widely recognized indicator of gender inequities, and it exists across industries and professional levels. There are different ways of measuring the gap, but no matter how you measure it, the gap still exists" (Canadian Women's Foundation, 2022, para. 1).

The immigrant wage gap, according to the Conference Board of Canada is widely recognized: "despite their high levels of education, Canadian immigrants have higher unemployment rates and lower wages than Canadian-born workers" (2022, para. 8). The immigrant wage gap is also gendered, meaning that the wage gap is larger between immigrant women and Canadian born-women, than is the gap between immigrant men and Canadian-born men (Conference Board of Canada, 2022, para. 19). The graph below depicts the immigrant wage gap by province, as well as a gender pay gap, where the gap was higher for men in three provinces. 


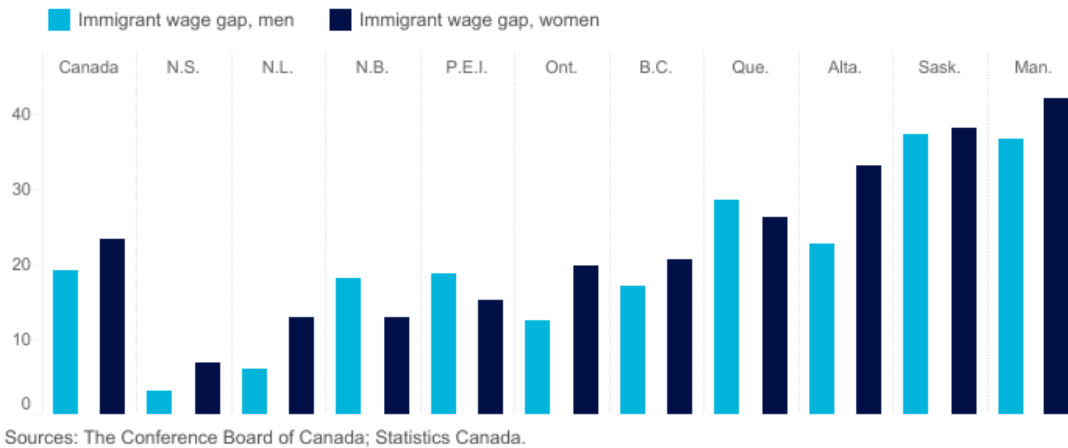

Image: Conference Board of Canada and Statistics Canada. (2022). Immigrant wage gap higher for women in most provinces, 2015 [Graph]. https://www.conferenceboard.ca/hcp/provincial/ society/immigrant-gap.aspx. Copyright Conference Board of Canada, 2022.

Learning Activity 9: Pay Gaps

This section serves as a brief introduction to the concepts of the gender pay gap and the immigrant wage gap. Brainstorm any questions you have about this research.

Review the websites cited in this section to research your answers:

- The Canadian Women's Foundation - Gender Pay Gap

- The Conference Board of Canada - Immigrant Wage Gap

\section{Discussion:}

1. What is the relationship between gender equality and the concept of a wage or pay gap?

2. In light of what you have learned about gender pay gaps and immigrant wage gaps, what role do settlement workers play in supporting newcomers? 


\section{Gender}

In this section, we will begin by exploring the concept of gender itself. It is essential to define the concept of gender as we explore what it means to apply a gender lens as a worker in the settlement sector. As you read the following definitions of gender, take note of key ideas and the differences between them, then complete the activities to understand how we will think about gender in this chapter.

Definition 1

Statistics Canada (2021) uses the following definition of gender:

\section{Gender of Person}

Gender refers to an individual's personal and social identity as a man, woman, or non-binary person (a person who is not exclusively a man or a woman). Gender includes the following concepts:

- gender identity, which refers to the gender that a person feels internally and individually;

- gender expression, which refers to the way a person presents their gender, regardless of their gender identity, through body language, aesthetic choices, or accessories (e.g., clothes, hairstyle, and makeup), which may have traditionally been associated with a specific gender.

A person's gender may differ from their sex at birth and from what is indicated on their current identification or legal documents such as their birth certificate, passport, or driver's licence. A person's gender may change over time. Some people may not identify with a specific gender. 
The following is an excerpt from the World Health Organization's (2022, para. 1-2) description of gender as it is related to health:

\section{Gender and Health}

Gender refers to the characteristics of women, men, girls, and boys that are socially constructed. This includes norms, behaviours, and roles associated with being a woman, man, girl, or boy, as well as relationships with each other. As a social construct, gender varies from society to society and can change over time.

Gender is hierarchical and produces inequalities that intersect with other social and economic inequalities. Gender-based discrimination intersects with other factors of discrimination, such as ethnicity, socio-economic status, disability, age, geographic location, gender identity, and sexual orientation, among others. This is referred to as intersectionality.

Margaret Robinson, a Two-Spirit Indigenous scholar, a Mi'kmaw woman, and a member of the Lennox Island First Nation, writes about the interrelationships among the concepts of gender, land, relationships, and nature:

To write about Indigenous gender I have to start with land. 
A Mi'kmaw Creation Story suggests that we have sprung from the land, like a plant, and that my continued existence and identities are rooted in my relationship with the land that birthed me. Land shapes my relationship with humans and other animals in the web of life around me, creating culture and identity. Land shapes language, teaching us what can be said about anything (including gender) and what must remain ineffable. And if we're starting with land, we need to frame our analysis of gender and sexuality around the fact that the land, and the people who spring from it, are actively being colonized (Robinson, 2021, p. 1676).

What are the key attributes that make up a definition of gender? Drag the missing words from the definitions of gender provided by Statistics Canada, the World Health Organization, and Margaret Robinson above into the correct boxes.

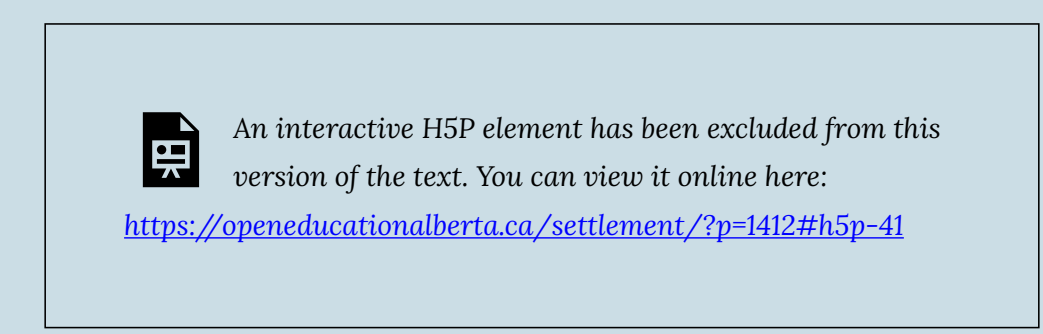




\section{Further Reading}

Human Rights in Canada by the Canadian Human Rights Commission is a webpage that outlines national and provincial/territorial frameworks for human rights protections in Canada.

Our Stories: First Peoples in Canada by Centennial College (2018) is an e-textbook and multimedia resource developed with Indigenous peoples from across Canada. It includes a chapter dedicated the topic of gender identities, which provides further descriptions of gender within Indigenous communities, including Two-Spirit identities, Indigenous masculinities, and women's issues.

Indigenous Canada by the Faculty of Native Studies at the University of Alberta (2016) is a popular massive open online course (MOOC) that explores the historical and present-day realities of Indigenous peoples in Canada. It includes a unit on Indigenous women featuring scholars Dr. Tracy Bear and Dr. Billy-Ray Belcourt.

Racialized Bodies, Disabling Worlds: Storied Lives of Immigrant Muslim Women by Parin Dossa shares Canadian women's narratives and analyzes how gender intersects with other identity factors to shape women's experiences, including disability, race, immigration status, and gender. 


\section{Gender Roles}

As defined by Little (2016), the term gender role refers to "society's concept of how men and women are expected to act and how they should behave" (p. 496). A gender role works like an unwritten rule and tends to rely on generalizations or stereotypes. Stereotypes may include generalizations such as men are practical, whereas women are emotional; men are strong, but women are frail; men lead while women support. Gender roles frame gender as a binary-a concept composed of two parts that are framed as absolute and unchanging opposites (Kang et al., 2017, p. 48).

Examples of binaries and some questions to consider:

- Are there only two categories to choose from?

Black

Masculine

Rich

- What is in between?

- Can you identify as neither?

Straight

Able-bodied

White

Feminine

Poor

Gay

Disabled

In a binary, women and men appear as polar opposites, their differences exaggerated. Most people do not fit neatly into one category such as those shown in the examples of binaries above. The "binary system" is persistent in society and is typically visible on a day-to-day basis. For example, a client intake form or activity registration form may ask for the gender of the participant and allow a checkbox for one of two gender options-male or female.

Culture does shift, however. Canadians can now identify as gender $\mathrm{X}$ on their passports, birth certificates, and ID cards. This move signifies that Canadians are becoming more aware of non-binary identities. However, binaries such as "masculine" and "feminine" still exist. Behaviours, mannerisms, likes and dislikes, objects, and the clothing you wear can often be "gendered" as masculine or feminine. A person may feel more comfortable with a non-binary identity if they do not conform to traditional conceptions of masculinity and femininity. 
NOTE: This activity works well as an in-class discussion or online forum discussion.

In a binary system, masculinity is understood as the opposite of femininity. In some cases, a person is subject to prejudice or even violence when they act outside an expected gender role. For the purposes of this activity, consider the biases, stereotypes, and expectations placed upon individuals' behaviour to be "gender laws."

Instructions: Think about typical conceptions of masculinity and femininity. Consider the behaviours and traits. For each behaviour or trait, in your experience, is it typically considered masculine, feminine, both, or neither?

a. This person wants to be a politician.

b. This person wants to take a woman on a (romantic) date.

c. This person wants to marry a man.

d. This person plays the harp.

e. This person works in the theatrical arts.

f. This person loves hockey.

g. This person wears makeup.

h. This person stays home and raises children.

\section{Discussion:}

1. Which characteristics did you associate strongly with men versus women? For the purpose of this activity, these characteristics might be conceived as "gender laws."

2. What happens when individuals break a gender law?

3. How are gender laws the same or different in your country or nation of origin? 
Watch the videoIndigenous Women and the Story of Canada by Sara Robinson (The Walrus Talks).

In the video, Sara Robinson, lawyer and Indigenous women's right advocate, talks about Indigenous Women and the story of Canada. She is described as a citizen of the Fort Nelson First Nation and the Saulteau First Nation in Treaty 8 territory. She served in the Minister's Advisory Council on Indigenous Women, and was founder and principal at Rainwatch Consulting and an Action Canada Fellow. She passed away in 2021 (The Walrus, 2017).

\section{Discussion:}

1. What is the relationship between masculinity and femininity and the colonization of land?

2. Why does the concept of gender equality need to consider Indigenous women and the history of Canada?

3. What are Sara's suggestions for you "as a character and as an author" in creating a better story of Canada? Think about your perspective as an individual in the settlement sector.

\section{Gender Stereotypes}

The "Gender Laws" activity above, which had you think about traits and behaviours typically perceived as masculine or feminine, relies on gender stereotypes. Consider the following definition:

A gender stereotype is a generalized view or preconception about attributes or characteristics, or the roles that are or ought to be possessed by, or performed by women and men. A gender stereotype is harmful when it limits women's and men's capacity to develop their personal abilities, pursue their professional careers, and make choices about their lives (United Nations OHCHR, 2022, para. 4).

The phrase "doing gender" is helpful in describing the ways in which people take on stereotypical masculine or feminine roles (West \& Zimmerman, 1987). For example, 
in a heteronormative family structure (that is, a heterosexual couple and children), gender roles tend to organize the family arrangements and expectations of how men and women should act in the family-men act as breadwinners, while women take on the majority of household labour. Hari (2018) points to the systemic barriers that perpetuate couples in typical gender roles in a study of skilled immigrant heterosexual couples from India aspiring to work in Ontario's tech sector. In this study, both men and women faced racial discrimination in the job market and challenges accessing appropriate and affordable child care. Almost all couples agreed that the female partners would "scale back" their career progressions to take care of children because their male partners earned higher wages. Despite the couples' preference for an egalitarian relationship in career and home life, systemic barriers to the labour market shaped the couple to maintain typical gender roles in the family.

Leigh (2015) discusses the ways that immigration can "undo" gender in her study of skilled immigrants in an Alberta city. The process of immigration can create situations in which gender dynamics are in flux because of new circumstances such as barriered access to the labour market, as discussed above. For example, a woman may find a job to cover basic family finances before a man is able to find a job in his field. Gender "role reversal" describes how gender becomes "undone" when, in a heteronormative family structure, the man takes on a gender role traditionally associated with a woman and vice versa. This shift can create family tension, as well as opportunities for change. Some couples welcome this change, such as a more equitable share of child-rearing and a chance to deepen relationships with children, whereas others find their new roles deeply challenging to their settlement experiences, such as sacrificing the career aspirations they had held for Canada (Leigh, 2015).

The immigration process can lead to a number of challenges for families, including financial strain, emotional strain, changes in parent-child relationships, and changes in familial and gender roles (Leigh, 2015). Okeke-Ihejirika and Salami (2018), in a study of immigrant men from Africa, describe the context in which "the shift in the financial balance of power often upsets the taken-for-granted division of gender roles in the family" (p. 101). After arriving in Canada, the study participants tell a story common to the immigrant experiences highlighted in Leigh (2015) and Hari (2018) noted above. Participants had little in terms of support systems, and despite being highly educated and experienced, their credentials were unrecognized or undervalued, leading to deskilling, unemployment, or underemployment (Okeke-Ihejirika \& Salami, 2018, p. 92). Okeke-Ihejirika and Salami point to the relationship between men's economic integration and their experiences of gender, marital, and family tensions. Their suggestions for settlement services include improved supports for men, increased intercultural sensitivity to the particular complexities of cultural groups, and engaging cultural elders and leaders to inform programming and policy (Okeke-Ihejirika \& Salami, 2018, p. 107). Although a "gender lens" often refers to the rights of women, 
the well-being and settlement experiences of men and the ability of a couple to work together creates potential for success for both partners.

An awareness of the variables impacting gender relations contributes to a settlement worker's sensitivity and empathy in working with the whole family. Importantly, a family may consist of a heterosexual or same-sex couple, with or without dependents. Stereotypes or values surrounding gender roles, and the division of household labour and child care, mediate a family's economic integration, which is intimately tied to their well-being. Importantly, the pathways to Canada available through different immigration classes create both constraints and possibilities in the family lives of immigrants and newcomers. In many cases, families do not migrate together at the same time, adding another set of variables that impact both gender and family relations.

\section{Vignette by Esther D.}

My family's immigration story is not unique to other Filipino migrants. Both of my parents left the Philippines when I was a child to work overseas. I was two years old when my mother left for America as an undocumented immigrant working odd jobs. She was our family's main source of income for a few years until my father left for Canada and worked as a live-in caregiver. Though the method in which Filipinos migrate to their countries of residence can differ (different streams of immigration), the one ubiquitous duty Filipino immigrants and temporary workers share are the remittances they send back to the Philippines, supporting the country's economy.

The need for overseas remittance arose as a solution to the foreign debt accumulated by the Marcos regime (1965 to 1985), which heavily backed and encouraged the labour export of Filipino workers. On the other hand, this was also favoured by the labourreceiving countries as it allowed them to exploit cheap and, oftentimes, disposable labour (Galerand, Gallié, \& Ollivier-Gobeil, 2015).

Canada's Live-in Caregiver Program (LCP) perfectly reflects this model. The LCP emerged in 1992 and lasted until 2014, when it was replaced by the Caregiver Program under the Temporary Foreign Worker Program (TFWP). The LCP is what brought my father to Canada in 2000. He worked as a live-in caregiver for four years, enduring different forms of abuse and being overworked before he could apply for his Permanent Residence (PR) and apply to sponsor my mother and me so that we could reunify.

Being separated as a family unit for many years undoubtedly impacted our familial relationship. I grew resentful towards my parents in my childhood because while they parented other people's children, they, by default, neglected to parent me from across 
the world. Only now in my adulthood did my family begin to acknowledge and repair the strain our transnational family dynamic had on our relationships, as well as the trauma that both of my parents continue to carry.

Effective April 30, 2022, Canada increased its capacity for Temporary Foreign Workers (TFWs) to $30 \%$. Formerly at $10 \%$, sectors with labour shortages can hire up to $20 \%$ more TFWs (ESDC, 2022). Although statistics and figures help us to understand and contextualize immigration, the individuals behind those numbers, such as my parents, each have their own stories and sacrifices worth uncovering. 


\section{Gender-Based Analysis Plus}

As a settlement worker, you may be curious as to how the Canadian government's gender lens impacts your field. The federal government applies Gender Based Analysis Plus $\left(\mathrm{GBA}^{+}\right)$as both an analytical process and a method of assessing how diverse groups of people experience policies, programs, and initiatives, and then acts on the results (Women and Gender Equality Canada, 2022c, para. 2). Immigration, Refugees and Citizenship Canada (IRCC), the federal government department that offers programming to help newcomers settle in Canada, is required under the Immigrant and Refugee Protection Act (IRPA) to include a GBA+ assessment of its programs and impact (IRCC, 2021b). Although GBA+ can be seen in progress in a number of areas within the IRCC portfolio, major initiatives begun in 2020-2021 include plans to address gender-based violence, the needs of caregivers, labour integration for visible minority newcomer women, and supports for LGBTQ refugees arriving through private sponsorship (IRCC, 2022c).

IRCC is not the only department responsible for implementing GBA+. All federal departments and agencies are supported by the Department of Women and Gender Equality Canada to implement GBA+ with end goal being gender equality. Gender mainstreaming, or the application of a gender lens to programs and policy, is not unique in government or intergovernmental operations (UN Women, 2022). Although Canada committed to gender-based analysis in 1995, it was not until 2016 that the "plus" sign $(+)$ was introduced to highlight the inclusion of diverse identity factors in this type of analysis, including religion, ethnicity and race, language, sexual orientation, income, culture, geography, disability, age, religion, and education (Women and Gender Equality Canada, 2022b). The GBA+ approach has faced criticism for emphasizing gender and sex and "adding on" other identity factors rather than incorporating a more rigorous analysis; Hankivsky \& Mussel (2018) describe its lack in addressing disability in particular (p. 304). More research, analysis, and awareness are required to understand how identity factors work in tandem to impact newcomers' settlement outcomes and the ability of newcomers to participate fully, with dignity, in Canadian society.

A free online $\mathrm{GBA}+$ course is available to the public to learn more. Some groups have innovated the GBA+ approach to share focus with a particular identity. For example, Women of the Métis Nation/Les Femmes Michif Otipemisiwak created a Métis-Specific GBA+ Tool to ensure that the realities facing Métis women are represented in public policy.

Various other community organizations have designed practical toolkits to guide individuals and organizations in applying GBA+ to their own work. Examples are listed below: 
- Canadian Research Institute for the Advancement of Women: Gender Equality and Intersectional Analysis Toolkit (Khosla, 2021)

- Canadian Council for Refugees: Pathways to Gender Justice Handbook: Applying a Gender Lens in Working with Newcomers

- Ontario Council of Agencies Serving Immigrants (OCASI): Accessibility Kit 


\section{Chapter References and Attributions}

\section{References}

Affiliation of Multicultural Societies and Service Agencies of BC (AMSSA). (2014). Migration matters: Settlement challenges of lesbian, gay, bisexual and transgender (LGBT) immigrants and refugees. https://www.amssa.org/wp-content/uploads/ 2020/09/AMSSA-Info-Sheet-Issue-18-Settlement-Challenges-of-LGBTImmigrants-and-Refugees.pdf

Alberta Association of Immigrant Serving Agencies (AAISA). (2022). Story of impact: Settlement agencies in Alberta blazing the trail for LGBTQ + newcomers. https://aaisa.ca/toolkit/story-of-impact-settlement-agencies-in-alberta-blazingthe-trail-for-lgbtq-newcomers/

AMSSA. (2015, June 19). The journey of LGBTQ immigrants and refugees in Canada [Video]. YouTube. https://www.youtube.com/ watch?v=Unia4pU7o6M\&ab channel=AMSSA

Amnesty International. (2022). Women's rights. https://www.amnesty.org/en/whatwe-do/discrimination/womens-rights/

Canadian Council for Refugees. (2009). Pathways to gender justice handbook: Applying a gender lens in working with newcomers. https:/ccrweb.ca/files/ genderhandbook.pdf

Canadian Council for Refugees. (2006). Pathways to gender justice: A toolkit for people working in the immigrant and refugee serving sector in Canada. https://ccrweb.ca/ sites/ccrweb.ca/files/gender.pdf

Canadian Human Rights Commission. (2021, June 12). Human rights in Canada. https://www.chrc-ccdp.gc.ca/en/about-human-rights/human-rights-canada

Canadian Women's Foundation. (2022). The facts about the gender pay gap. https://canadianwomen.org/the-facts/the-gender-pay-gap/

Centennial College. (2018a). 26. Gender identities. In Our stories: First peoples in Canada. eCampusOntario. https://ecampusontario.pressbooks.pub/indigstudies/ chapter/gender-identities/licensed under CC BY-NC-ND 4.0

Centennial College. (2018b). Our stories: First peoples in Canada. eCampusOntario. 
https://www.centennialcollege.ca/indigenous-education/our-stories-firstpeoples-in-canada/ licensed under CC BY-NC-ND 4.0

City of Edmonton. (2018, April 12). Gender-based analysis + : What is it and why? [Video]. YouTube. $\quad \underline{h t p s: / / w w w . y o u t u b e . c o m / w a t c h ? v=p 6 w-}$ d1mmjFU\&ab_channel=CityofEdmonton

Conference Board of Canada. (2022). Immigrant wage gap. https://www.conferenceboard.ca/hcp/provincial/society/immigrant-gap.aspx

Department of Justice. (2022). State of the criminal justice system dashboard: Genderdiverse. Government of Canada. https://www.justice.gc.ca/socjs-esjp/en/womenfemmes/Definitions\#Gender diverse

Desouza, R. (2007). Women, Portuguese culture and diaspora: Women from Goa in New Zealand and cultural appropriation. Campus Social, 3/4, 107-122. https://www.researchgate.net/publication/

236894701_Women_Portuguese_culture_and_Diaspora_Women_from_Goa_in_ New Zealand and cultural adaptation

Domingo, Z. (2022, May 4). Why is gender equality important? GVI. https://www.gvicanada.ca/blog/why-is-gender-equality-important/

Donald, D. (2014). Teaching and learning from Aboriginal perspectives in the social studies classroom [Unpublished report]. Edmonton Public Schools.

Dossa, P. (2009). Racialized bodies, disabling worlds: Storied lives of immigrant Muslim women. University of Toronto Press. https://utorontopress.com/9780802095510/ racialized-bodies-disabling-worlds/

Egale Canada. (n.d.). Trans and nonbinary identities and gender diversity: Terms and concepts. https://egale.ca/wp-content/uploads/2022/03/Trans-and-NonbinaryIdentities-Terms-and-Concepts-2.0.pdf

Employment and Social Development Canada (EDSC). (2022). Government of Canada announces Workforce Solutions Road Map - further changes to the Temporary Foreign Worker Program to address labour shortages across Canada [News release]. Government of Canada. https://www.canada.ca/en/employment-socialdevelopment/news/2022/04/government-of-canada-announces-workforcesolutions-road-map-further-changes-to-the-temporary-foreign-worker-program -to-address-labour-shortages-ac.html

Galerand, E., Gallié, M., \& Ollivier-Gobeil, J. (2015, January). Domestic labour and exploitation: The case of the Live-In Caregiver Program in Canada (LCP) [Research report].

https://www.mcgill.ca/lldrl/files/lldrl/

15.01.09_rapport_en_vu1.1.13_0.pdf 
Global Development Commons (GDC). (n.d.). The global gender gap report 2020. UNICEF. https://gdc.unicef.org/resource/global-gender-gap-report-2020

Goetz, A.-M. (2007). Gender justice, citizenship and entitlements - Core concepts, central debates and new directions for research. In M. Mukhopadhyay \& N. Singh (Eds.), Gender justice, citizenship and development (pp. 15-57). International Development Research Centre, Ottawa. https://gsdrc.org/document-library/ gender-justice-citizenship-and-entitlements-core-concepts-central-debates-andnew-directions-for-research/

Hankivksy, O., \& Mussell, L. (2018). Gender-based analysis plus in Canada: Problems and possibilities of integrating intersectionality. Canadian Public Policy, 44(4), 303-316. https://doi.org/10.3138/cpp.2017-058

Hari, A. (2018). "Someone kept sacrificing": Disentangling gender ideology in immigrant narratives of social reproduction. Signs, 43(3). https://www.journals.uchicago.edu/doi/10.1086/695299

ILGA World. (2022). Home page. https://ilga.org/

ILGA World. (2022). State-sponsored homophobia report. https://ilga.org/statesponsored-homophobia-report

Immigration and Refugee Board of Canada. (2022). Act, rules and regulations. https://irb.gc.ca/en/legal-policy/act-rules-regulations/Pages/index.aspx

Immigration, Refugees and Citizenship Canada (IRCC). (2021a). Gender-based analysis plus (GBA+): Institutional GBA+ capacity. Government of Canada. https://www.canada.ca/en/immigration-refugees-citizenship/corporate/ publications-manuals/departmental-plan-2021-2022/gender-based-analysisplus.html

Immigration, Refugees and Citizenship Canada (IRCC). (2021b). Gender-based analysis plus (GBA+): Introduction. Government of Canada. https://www.canada.ca/en/ immigration-refugees-citizenship/corporate/publications-manuals/ departmental-plan-2020-2021/gender-based-analysis-plus.html

Immigration, Refugees and Citizenship Canada (IRCC). (2021c). Settlement outcomes HIGHLIGHTS report Summary findings from IRCC's first settlement outcomes report 2021. Government of Canada. https://publications.gc.ca/collections/ collection 2021/ircc/Ci34-6-2021-eng.pdf

International Organization for Migration (IOM). (2022). Gender equality. https://www.iom.int/gender-equality

Kang, M., Lessard, D., Heston, L., \& Nordmarken, S. (2017). Introduction to women, 
gender, sexuality studies. https://openbooks.library.umass.edu/introwgss/ licensed under $\underline{\text { CC BY } 4.0}$

Khosla, P. (2021). Gender equality and intersectional analysis toolkit. Canadian Research Institute for the Advancement of Women (CRIAW). https://www.criaw-icref.ca/ publications/gender-equality-and-intersectional-analysis-toolkit/

Leigh, J. P. (2015). Skilled immigrants and the negotiation of family relations during settlement in Calgary, Alberta. Journal of International Migration and Integration, 17, 1065-1083. https://doi.org/10.1007/s12134-015-0454-9

Little, M., Marks, L., Beck, M., Paszat, E., \& Tom, L. (2020). Family matters: Immigrant women's activism in Ontario and British Columbia, 1960s-1980s. Atlantis: Critical Studies in Gender Culture E Social Justice, 41(1), 105-123. https://doi.org/10.7202/ $\underline{1074022 \mathrm{ar}}$

Little, W. (2016). Introduction to Sociology (2nd Canadian ed.). BCcampus. https://opentextbc.ca/introductiontosociology2ndedition/ licensed under CC BY 4.0 International

Luna, K. C. (2021). Fact sheet 3: Racialized women \& COVID-19 challenges in Canada. Canadian Research Institute for the Advancement of Women (CRIAW). https://www.criaw-icref.ca/publications/racialized-women-covid-19-challengesin-canada/

Mendos, L. M., Botha, K., Lelis, R. C., López de la Peña, E., Savelev, I., \& Tan, D. (2020). State-sponsored homophobia: Global legislation overview update. ILGA World. https://ilga.org/downloads/

ILGA_World_State_Sponsored_Homophobia_report_global_legislation_overvie w_update_December_2020.pdf licensed under CC BY-SA 4.0 International

Mohanty, C. (1988). Under Western eyes: Feminist scholarship and colonial discourse. Feminist Review, 30(1), 61-88. https://doi.org/10.1057/fr.1988.42

National Inquiry into Missing and Murdered Indigenous Women and Girls. (2019). Reclaiming power and place: The final report of the National Inquiry into Missing and Murdered Indigenous Women and Girls, Volume 1a. https://www.mmiwg-ffada.ca/ wp-content/uploads/2019/06/Final_Report_Vol_1a-1.pdf

Okeke-Ihejirika, P., \& Salami, B. (2018). Men become baby dolls and women become lions: African immigrant men's challenges with transition and integration. Canadian Ethnic Studies, 50(3), 91-110. https://doi.org/10.1353/ces.2018.0024

Ontario Council of Agencies Serving Immigrants (OCASI). (2022). Positive spaces initiative: Home page. https://positivespaces.ca/ 
Ontario Council of Agencies Serving Immigrants (OCASI). (n.d.). Accessibility kit. https://ocasi.org/sites/default/files/accessibility-kit 0.pdf

Oxfam International. (2022a). 5 ways women and girls have been the hardest hit by Covid-19. $\quad$ https://www.oxfam.org/en/5-ways-women-and-girls-have-beenhardest-hit-covid-19

Oxfam International. (2022b). Gender justice and women's rights. https://www.oxfam.org/en/what-we-do/issues/gender-justice-and-womensrights

Parliament of Canada. (n.d.). Bill C-38: Civil Marriage Act. Statutes of Canada 2005, c. 33. 38th Parliament, 1st session. https://www.parl.ca/LegisInfo/en/bill/38-1/ C-38

Robinson, M. (2020). Two-Spirit identity in a time of gender fluidity. Journal of Homosexuality 67(12), 1675-1690. https://doi.org/10.1080/00918369.2019.1613853

Sarkar, U. (2022, January 21). What is gender equity and how is it different from gender equality? Feminism in India (FII). https://feminisminindia.com/2022/01/21/whatis-gender-equity-and-how-is-it-different-from-gender-equality/

Skoll.org. (2019, October 11). Muzoon Almellehan | Educate a girl, spark hope [Video]. YouTube.

https://www.youtube.com/ watch?v=LZax5RBPk2k\&ab_channel=Skoll.org

Standing Committee on the Status of Women. (2021). Impacts of the COVID-19 pandemic on women. House of Commons. 43rd Parliament, 2nd Session. https://publications.gc.ca/collections/collection_2021/parl/xc71-1/ XC71-1-1-432-6-eng.pdf

Statistics Canada. (2022). Average and median gender wage ratio, annual. https://www150.statcan.gc.ca/t1/tbl1/en/tv.action?pid=1410034002

Statistics Canada. (2021). Gender of person. https://www23.statcan.gc.ca/imdb/ p3Var.pl? Function=DEC\&Id $=410445$

Tyagi, R. (2014). Understanding postcolonial feminism in relation with postcolonial and feminist theories. International Journal of Language and Linguistics, 1(2), 45-50. https://ijllnet.com/journals/Vol 1 No 2 December 2014/7.pdf

UN Women. (2022). Handbook on gender mainstreaming for gender equality results. https://www.unwomen.org/sites/default/files/2022-02/Handbook-on-gendermainstreaming-for-gender-equality-results-en.pdf

UN Women. (2014a). World survey on the role of women in development 2014: Gender 
equality and sustainable development. https://sustainabledevelopment.un.org/ content/documents/1900unwomen surveyreport advance 16oct.pdf

UN Women. (2014b). The COVID-19 pandemic has increased the care burden, but by how much? https://data.unwomen.org/features/covid-19-pandemic-has-increasedcare-burden-how-much-0

UNICEF. (2022). Muzoon Almellehan, UNICEF Goodwill Ambassador. https://www.unicef.org/goodwill-ambassadors/muzoon-almellehan

United Nations (UN). (n.d.a). Girls not brides: The global partnership to end child marriage. $\quad$ https://sustainabledevelopment.un.org/ index.php?page $=$ viewEtype $=20036 \mathcal{E}$ menu $=1561 \mathcal{E} \mathrm{r}=55338$

United Nations (UN). (n.d.b). Sustainable development goals: Goal 5: Achieve gender equality and empower all women and girls. https://www.un.org/ sustainabledevelopment/gender-equality/

United Nations Development Programme (UNDP). (2022). The SDGs in action. https://www.undp.org/sustainable-development-goals

United Nations Human Rights Office of the High Commissioner (OHCHR). (2022). Gender stereotyping. https://www.ohchr.org/EN/Issues/Women/WRGS/Pages/ GenderStereotypes.aspx\#: :text=Gender\%20stereotyping\%20refers\%20to\%20the, group $\% 20$ of\%20women\%20or\%20men

United Nations Office on Drugs and Crime (UNODC). (n.d.). Impact of the COVID-19 pandemic on trafficking in persons. https://www.unodc.org/documents/AdvocacySection/HTMSS Thematic Brief on COVID-19.pdf

University of Alberta. (2016). Indigenous Canada [Online course]. Coursera. https://www.coursera.org/learn/indigenous-canada

USA for UNHCR. (2022, July 8). Syria refugee crisis explained. https://www.unrefugees.org/news/syria-refugee-crisis-explained/

The Walrus. (2017, March 3). Indigenous women and the story of Canada | Sarah Robinson | The Walrus Talks [Video]. YouTube. https://www.youtube.com/ watch?v=nDlIMMZ2gRM

Waring, R., Oyella, P., \& Atulinda, A. (2019, March 16). No white saviours: Meet the women behind the campaign [Video news article]. BBC News. https://www.bbc.com/news/av/world-africa-47587185

West, C., \& Zimmerman, D. H. (1987). Doing gender. Gender and Society, 1(2), 125-151. https://www.gla.ac.uk/0t4/crcees/files/summerschool/readings/ WestZimmerman_1987_DoingGender.pdf 
Women and Gender Equality Canada. (2022a). Introduction to GBA plus: Glossary: G. Government of Canada. https://women-gender-equality.canada.ca/gbapluscourse-cours-acsplus/eng/global/glossary_glossaire.html\#G

Women and Gender Equality Canada. (2022b). Introduction to GBA Plus: The history of GBA plus. Government of Canada. https://women-gender-equality.canada.ca/ gbaplus-course-cours-acsplus/eng/modA1/modA1_01_01.html

Women and Gender Equality Canada. (2022c). What is gender-based analysis plus. Government of Canada. https://women-gender-equality.canada.ca/en/genderbased-analysis-plus/what-gender-based-analysis-plus.html

Women and Gender Equality Canada. (2021). Snapshot: COVID-19 and gender-based violence. Government of Canada. https://women-gender-equality.canada.ca/en/ gender-based-violence-knowledge-centre/snapshot-covid-19-gender-basedviolence.html

Women of the Métis Nation/Les Femmes Michif Otipemisiwak. (2019). Métis-specific gender based analysis plus $\left(\mathrm{GBA}^{+}\right)$tool. https://metiswomen.org/wp-content/ uploads/2021/06/Metis-Specific-GBA-Tool.pdf

World Economic Forum (WEF). (2021). Global gender gap report 2021. https://www3.weforum.org/docs/WEF_GGGR_2021.pdf

World Health Organization (WHO). (2022). Gender and health. https://www.who.int/ health-topics/gender\#tab=tab 1 
CHAPTER 7: HOW LITERACY

AFFECTS THE SETTLEMENT OF

IMMIGRANT WOMEN 



\title{
Introduction
}

\author{
MARIA MACMINN VARVOS
}

The settlement challenges and strategies for the success of immigrant women with low first-language literacy (LFLL) skills will be explored in this chapter.

Immigrant women have struggled with settlement and integration with varying levels of success. Their identity is tied to the status they left behind, and the struggle to navigate a new social system is often tied to their capacity to adapt to a highly literate environment. The challenges of integration and settlement are compounded when they need additional English-language and literacy skills.

This chapter will explore the relationship between adult literacy and second-language literacy that relates to settlement and integration. It will review lived experiences, sample program models, case studies, and research studies, and provide interactive reflective practice assignments. These elements will serve as the impetus for learning and skill development in this course.

Specific Learning Outcomes

By the end of this chapter, you should be able to

1. Integrate knowledge of the challenges of immigrant women with low first-language literacy (LFLL) into your settlement practices

2. Develop critical problem-solving strategies in clinical practice based on the settlement strategies presented in this chapter

3. Develop strategies that would meet the needs of immigrant women with low first-language literacy (LFLL). 


\section{Introduction to Chapter Study}

Section-Specific Learning Outcomes

By the end of this section, you should be able to

1. Define the terminology that will be used in this chapter

2. Apply tips for navigating this chapter

Test your knowledge and find out how many terms you already know.

An interactive H5P element has been excluded from this version of the text. You can view it online here:

https://openeducationalberta.ca/settlement/?p=1317\#h5p-40

Click Check to find out whether or not your answers were correct, and click Show Solution to see the correct answers. 


\section{Tips for Navigating this Chapter}

- Make use of the links to additional information that will expand your reading and understanding of the content; the videos will give you a more personal connection to the content.

- Start a journal to answer reflective questions. This is especially important if you are taking this course asynchronously.

- If you are taking this course asynchronously, answer the reflection questions in your journal. 


\section{Adult Literacy, Life Skills, and Settlement}

Section-Specific Learning Objectives

By the end of this section, you should be able to

1. Describe how second-language literacy relates to settlement and integration success

2. Describe the relationship between adult literacy and life skills

3. Apply these learnings to a reflective response for this topic

Immigration, Refugees and Citizenship Canada (IRCC) defines the settlement of immigrants in Canada as the following:

[A] short period of mutual adaptation between the newcomers and the host society, during which the government provides support and services to newcomers. Integration is a two-way process that involves commitment on the part of immigrants to adapt to life in Canada and on the part of Canada to welcome and adapt to new peoples and cultures (IRCC, 2022, section 2.3).

How does the Canadian government measure the outcomes that demonstrate that a newcomer has achieved settlement and integration? The benchmarks are measured by Canadian Certified Language Assessment Centres that are situated in immigrantserving agencies or in designated colleges that offer language programs to newcomers. The following is a summary list of the services provided by the Government of Canada Settlement Program:

- Support services that enable clients to access services

- Needs and assets assessment and referrals

- Information and orientation

- Language training

- Employment-related training

- Community connections

340 | Adult Literacy, Life Skills, and Settlement 
One of these six service areas is language training, which is explained as "Services that support clients in developing official language skills required for the labour market and/or navigating life outside work" (IRCC, 2022, section 3.3d). Language acquisition includes both oral language (listening, speaking) and literacy (reading, writing), and one of the first services that newcomers are offered is language training. Learning one of Canada's two official languages in addition to settlement services are what support the ability of newcomers to "navigate" life in Canada and the degree to which they do so independently.

This section of the chapter will explore the following two questions :

- What is the difference between oral language ability and literacy ability?

- How does literacy development affect life skills?

You will explore these questions to subsequently understand the degree to which newcomers successfully settle and integrate into their new society.

\section{Lack of Education Does Not Equal Lack of Ability}

Today, day-to-day activities presume that adults have a basic level of literacy. Many life skills require the ability to read and write, including employment applications, banking, healthcare information, and transportation. Low literacy ultimately leads to limited independence. Fundamental reading, writing, and numeracy, as well as basic critical-thinking and problem-solving skills, are the literacy foundational skills that give adults control over their environment in everyday life.

In parts of the world where education is available to all, literacy skills are developed starting in an individual's formative years and according to a child's physical and cognitive development. If these literacy skills are missed during the cognitive stage of development and no additional explicit pedagogical instruction is received, then acquiring the foundational skills required to live independently as an adult is challenging. Learning as an adult is different than learning as a child. Learning as a child is defined as pedagogy, whereas learning as an adult is call andragogy:

- Pedagogy: Content is at the centre of learning, and teachers develop instructional methods to teach content. A child's learning is a process that develops according to their increasing ability for higher-order thinking. The ability to learn skills is related to a child's physical and cognitive development. 
- Andragogy: The term "andragogy" refers to the methods and principles used to teach adults. Adult learning is a self-directed pursuit that is motivated by choice and/or need. Adults acquire knowledge or skills in a specialized field to expand knowledge for personal enrichment (Brookfield, 1986) or for employment-skills training. They learn new skills and knowledge when they see a purpose in learning. Knowles explains: "As a person matures the motivation to learn is internal" (Knowles, 1984).

\section{Literacy - What is it? How does it fit into the settlement process?}

Literacy is described by Statistics Canada as having five levels that are based on the Programme for the International Assessment of Adult Competencies (PIAAC) scale (Statistics Canada, 2022).

The following data is from Table 1.1 Literacy, which compares Canadian literacy levels to the five levels of literacy on the PIAAC scale (Statistics Canada, 2015). The table is based on research by the OECD (Organisation for Economic Co-operation and Development). 


\begin{tabular}{|c|c|c|c|}
\hline Level & $\begin{array}{l}\text { Score } \\
\text { range }\end{array}$ & $\begin{array}{l}\text { Percentage of } \\
\text { the population } \\
\text { aged } 16 \text { to } 65\end{array}$ & Characteristics of literacy tasks \\
\hline 5 & $376-500$ & $\begin{array}{l}1 \% \text { of } \\
\text { populations } \\
\text { across OECD } \\
\text { and } 1 \% \text { in } \\
\text { Canada can } \\
\text { successfully } \\
\text { perform tasks } \\
\text { at Level } 5 .\end{array}$ & $\begin{array}{l}\text { At this level, tasks may require the respondent to search } \\
\text { for and integrate information across multiple, dense } \\
\text { texts; construct syntheses of similar and contrasting } \\
\text { ideas or points of view; or evaluate evidence-based } \\
\text { arguments. Application and evaluation of logical and } \\
\text { conceptual models of ideas may be required to } \\
\text { accomplish tasks. Evaluating reliability of evidentiary } \\
\text { sources and selecting key information is frequently a } \\
\text { key requirement. Tasks often require respondents to be } \\
\text { aware of subtle, rhetorical cues and to make high-level } \\
\text { inferences or use specialized background knowledge. }\end{array}$ \\
\hline 4 & $326-375$ & $\begin{array}{l}12 \% \text { of } \\
\text { populations } \\
\text { across OECD } \\
\text { and } 14 \% \text { in } \\
\text { Canada can } \\
\text { successfully } \\
\text { perform tasks } \\
\text { at least at Level } \\
4 . \\
\text { Adults scoring } \\
\text { at Level } 4 \text { : } \\
\text {-11\% OECD } \\
\text {-13\% Canada }\end{array}$ & $\begin{array}{l}\text { Tasks at this level often require respondents to perform } \\
\text { multistep operations to integrate, interpret, or } \\
\text { synthesize information from complex or lengthy } \\
\text { continuous, non-continuous, mixed, or multiple type } \\
\text { texts. Complex inferences and application of } \\
\text { background knowledge may be needed to perform } \\
\text { successfully. Many tasks require identifying and } \\
\text { understanding one or more specific, non-central ideas } \\
\text { in the text in order to interpret or evaluate subtle } \\
\text { evidence-claim or persuasive discourse relationships. } \\
\text { Conditional information is frequently present in tasks at } \\
\text { this level and must be taken into consideration by the } \\
\text { respondent. Competing information is present and } \\
\text { sometimes seemingly as prominent as correct } \\
\text { information. }\end{array}$ \\
\hline 3 & $276-325$ & $\begin{array}{l}51 \% \text { of } \\
\text { populations } \\
\text { across OECD } \\
\text { and } 51 \% \text { in } \\
\text { Canada can } \\
\text { successfully } \\
\text { perform tasks } \\
\text { at least at Level } \\
3 . \\
\text { Adults scoring } \\
\text { at Level 3: } \\
\text { - 39\% OECD } \\
\text {-38\% Canada }\end{array}$ & $\begin{array}{l}\text { Texts at this level are often dense or lengthy, and } \\
\text { include continuous, non-continuous, mixed, or multiple } \\
\text { pages of text. Understanding text and rhetorical } \\
\text { structures become more central to successfully } \\
\text { completing tasks, especially navigating of complex } \\
\text { digital texts. Tasks require the respondent to identify, } \\
\text { interpret, or evaluate one or more pieces of information, } \\
\text { and often require varying levels of inference. Many tasks } \\
\text { require the respondent to construct meaning across } \\
\text { larger chunks of text or perform multistep operations in } \\
\text { order to identify and formulate responses. Often tasks } \\
\text { also demand that the respondent disregard irrelevant or } \\
\text { inappropriate content to answer accurately. Competing } \\
\text { information is often present, but it is not more } \\
\text { prominent than the correct information. }\end{array}$ \\
\hline
\end{tabular}




\begin{tabular}{|c|c|c|c|}
\hline 2 & $226-275$ & $\begin{array}{l}85 \% \text { of } \\
\text { populations } \\
\text { across OECD } \\
\text { and } 83 \% \text { in } \\
\text { Canada can } \\
\text { successfully } \\
\text { perform tasks } \\
\text { at least at Level } \\
2 . \\
\text { Adults scoring } \\
\text { at Level 2: } \\
\text { - } 34 \% \text { OECD } \\
\text { 32\% Canada }\end{array}$ & $\begin{array}{l}\text { At this level, the medium of texts may be digital or } \\
\text { printed, and texts may comprise continuous, non- } \\
\text { continuous, or mixed types. Tasks at this level require } \\
\text { respondents to make matches between the text and } \\
\text { information and may require paraphrasing or low-level } \\
\text { inferences. Some competing pieces of information may } \\
\text { be present. Some tasks require the respondent to } \\
\text { - Cycle through or integrate two or more pieces of } \\
\text { information based on criteria } \\
\text { - Compare and contrast or reason about information } \\
\text { requested in the question } \\
\text { inavigate within digital texts to access and identify } \\
\text { information from various parts of a document }\end{array}$ \\
\hline 1 & $176-225$ & $\begin{array}{l}97 \% \text { of } \\
\text { populations } \\
\text { across OECD } \\
\text { and } 96 \% \text { in } \\
\text { Canada can } \\
\text { successfully } \\
\text { perform tasks } \\
\text { at least at Level } \\
1 . \\
\text { Adults scoring } \\
\text { at Level 1: } \\
\text {-12\% OECD } \\
\text { 13\% Canada }\end{array}$ & $\begin{array}{l}\text { Most of the tasks at this level require the respondent to } \\
\text { read relatively short digital or print continuous, non- } \\
\text { continuous, or mixed texts to locate a single piece of } \\
\text { information that is identical to or synonymous with the } \\
\text { information given in the question or directive. Some } \\
\text { tasks, such as those involving non-continuous texts, } \\
\text { may require the respondent to enter personal } \\
\text { information onto a document. Little, if any, competing } \\
\text { information is present. Some tasks may require simple } \\
\text { cycling through more than one piece of information. } \\
\text { Knowledge and skill in recognizing basic vocabulary, } \\
\text { determining the meaning of sentences, and reading } \\
\text { paragraphs of text is expected. }\end{array}$ \\
\hline $\begin{array}{l}\text { Below } \\
1\end{array}$ & 0-175 & $\begin{array}{l}\text { Adults scoring } \\
\text { below Level 1: } \\
\text { • } 3 \% \text { OECD } \\
\text { - } 4 \% \text { Canada }\end{array}$ & $\begin{array}{l}\text { The tasks at this level require the respondent to read } \\
\text { brief texts on familiar topics to locate a single piece of } \\
\text { specific information. There is seldom any competing } \\
\text { information in the text and the requested information is } \\
\text { identical in form to information in the question or } \\
\text { directive. The respondent may be required to locate } \\
\text { information in short continuous texts. However, in this } \\
\text { case, the information can be located as if the text were } \\
\text { non-continuous in format. Only basic vocabulary } \\
\text { knowledge is required, and the reader is not required to } \\
\text { understand the structure of sentences or paragraphs or } \\
\text { make use of other text features. Tasks below Level } 1 \text { do } \\
\text { not make use of any features specific to digital texts. }\end{array}$ \\
\hline
\end{tabular}

Reprinted from Table 1.1 Literacy - Description of proficiency levels (Archived content), by Statistics Canada, 2015. https://www150.statcan.gc.ca/n1/pub/89-555-x/2013001/t/tbl1.1-eng.htm. Reproduced under the Statistics Canada Open Licence. This does not constitute an endorsement by Statistics Canada of this product.

Note: UNESCO defines literacy as "the ability to identify, understand, interpret, create, communicate, compute and use printed, and written materials associated with varying contexts. Literacy involves a continuum of learning to enable an individual to achieve his or her goals, to develop his 
or her knowledge and potential, and to participate fully in the wider society" (UNESCO Institute for Statistics, 2022).

ESL low-literacy descriptors (CCLB, 2022a) and the ESL Literacy Assessment Tools project (CIWA, 2017a) defined the levels of foundation literacy given in the table below. Compare these levels with "Below 1" level on the PIACC scale in the previous table; note that the literacy levels are much lower than the "Below 1" level on the PIACC scale.

Learners may be preliterate, non-literate, or semi-literate, as defined in the table below (CIWA, 2017a):

\begin{tabular}{|l|l|l|}
\hline \multicolumn{2}{|c|}{ Pre-literate } & \multicolumn{1}{c|}{ Semi-literate } \\
\hline $\begin{array}{l}\text { These learners come from oral } \\
\text { cultures where the spoken } \\
\text { languages do not have current } \\
\text { written forms or where print is } \\
\text { not regularly encountered in } \\
\text { daily life. }\end{array}$ & $\begin{array}{l}\text { These learners do not read or } \\
\text { write in any language, even } \\
\text { though they live in literate } \\
\text { societies. }\end{array}$ & $\begin{array}{l}\text { These learners have some } \\
\text { basic reading and writing } \\
\text { skills but are not yet } \\
\text { functionally literate. }\end{array}$ \\
$\begin{array}{l}\text { print convey not understand that } \\
\text { realize how important reading } \\
\text { and writing are in Canadian } \\
\text { society. }\end{array}$ & \begin{tabular}{l} 
\\
\hline
\end{tabular} & \\
\hline
\end{tabular}

The following Language Instruction for Newcomers (LINC) survey (Table A-4) conducted by Canada Immigration (now Immigration, Refugees and Citizenship Canada) in 2008 identified that the percentage of immigrant women at the L (Literacy) level was $4.2 \%$ and at the CLB 1 level was $13.9 \%$. 


\begin{tabular}{|c|c|c|c|c|}
\hline \multicolumn{2}{|c|}{ LINC Learner Characteristic } & $\begin{array}{l}\text { LINC Population } \\
(2008)^{*}\end{array}$ & $\begin{array}{l}\text { LINC Survey } \\
\text { Respondents }\end{array}$ & $\begin{array}{l}\text { LINC Case Study } \\
\text { Survey } \\
\text { Respondents }\end{array}$ \\
\hline \multirow{2}{*}{ Gender } & Female & 71.4\% & $73.5 \%$ & $79.9 \%$ \\
\hline & Male & 28.6 & 26.5 & 20.1 \\
\hline \multirow{7}{*}{$\begin{array}{l}\text { LINC CLB (Canadian } \\
\text { Language } \\
\text { Benchmarks) level }\end{array}$} & $\begin{array}{l}\mathrm{L} \\
\text { (Literacy) }\end{array}$ & $4.2 \%$ & $0.0 \%$ & $0.0 \%$ \\
\hline & 1 & 13.9 & 16.3 & 9.0 \\
\hline & 2 & 18.3 & 17.7 & 17.9 \\
\hline & 3 & 25.4 & 26.6 & 34.3 \\
\hline & 4 & 19.1 & 23.2 & 17.9 \\
\hline & 5 & 11.7 & 8.1 & 11.9 \\
\hline & $6-7$ & 7.2 & 8.1 & 9.0 \\
\hline
\end{tabular}

Adapted from "Table A-4: Survey respondents compare closely to the LINC population," in Evaluation of the Language Instruction for Newcomers to Canada (LINC) Program, by Immigration, Refugees and Citizenship Canada, Government of Canada, 2011. https://www.canada.ca/en/immigration-refugees-citizenship/ corporate/reports-statistics/evaluations/language-instruction-newcomers-canada-2010/appendixa.html The following chart shows the estimated rate of language acquisition based on a study conducted in 2004 by Deirdre Lake and David Watt (Lake \& Watt, 2014): 
Benchmark Adult Rate of Second Language Acquisition and Integrati

\begin{tabular}{|l|l|l|l|l|l|l|l|}
\hline \multirow{2}{*}{$\begin{array}{l}\text { Language } \\
\text { Component }\end{array}$} & \multirow{5}{*}{$\begin{array}{l}\text { Number of Years of } \\
\text { Education }\end{array}$} & \multicolumn{5}{|c|}{ Number of Hours Required to Move to Next Benchmar } \\
\cline { 3 - 8 } & \multicolumn{5}{|c|}{ Language Strand }
\end{tabular}

\section{Writing}

\begin{tabular}{|l|l|l|l|l|l|l|}
\hline & $0-7$ & 190 & 268 & 856 & & \\
\hline & $8-12$ & 325 & 299 & 403 & & \\
\hline & $13-16$ & 250 & 341 & 328 & 320 & 17 \\
\hline & $17+$ & 217 & 291 & 357 & 290 & 19 \\
\hline
\end{tabular}




\section{Something to think about:}

Review the chart above. What is the highest benchmark level that those with 0 to 7 years of education (low-literacy learners) achieve according to this study?

\section{Did you know?}

The CLB level that is required to take the Canadian Citizenship Test is CLB 4. Immigrants require proof that they have achieved CLB 4 or the equivalent before taking the test.

\section{The Causes of Low Literacy for Immigrant Women}

\section{Definition of Literacy in Different Stages of History and Cultures}

Literacy standards have evolved throughout history to meet the level of complexity of the systems that society has created for the day-to-day transactions that are required to keep up with the pace of everyday life.

Life has become progressively more complex since the early 1900s, starting with the onset of the Industrial Revolution in the mid-19th century and continuing with the fast pace of technology and science in the 21st century. The complexity of the systems that society has created over the past 120 -plus years has dramatically increased the literacy skills required to live and work in society.

Watch the video Endemic Illiteracy (Rockall-Schmidt, 2021). This video will take you on a journey through the development of literacy standards throughout time to 
demonstrate how literacy levels have advanced as our communication systems evolve in complexity.

Do the following while watching the video:

- Take note of how someone with no functional literacy skills would adapt and succeed at these different stages of literacy.

- Reflect on how technology has shaped the skills required to maintain the increasing technical complexity of our appliances and entertainment systems. New skills are also required for banking through ATMs and online banking, a change from the time when only limited levels of reading, writing, and numeracy were needed to go to a bank to perform transactions such as deposits and bill payments.

For an immigrant woman who does not have basic reading, writing, and numeracy skills, adding another layer of literacy is challenging and intimidating.

\section{How does literacy affect life skills? What literacy level is required to navigate independently?}

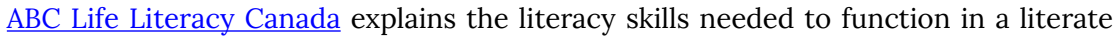
society:

Having adequate literacy skills means being able to understand, evaluate, use, and engage with written texts. It also means being able to participate in society, achieve your goals, and develop your knowledge and potential.

Research shows that adults who have inadequate literacy skills are more likely to have poorer overall health, lower salaries, and lower levels of participation in their community (ABC Life Literacy Canada, 2022).

\section{Health Literacy}

The World Health Organization (WHO) states that "[h]ealth literacy represents the cognitive and social skills which determine the motivation and ability of individuals to gain access to, understand, and use information in ways which promote and maintain good health" (World Health Organization, 1998). For LFLL immigrant women, access to health care is complicated by any number or combination of the following factors: 
- Inadequate language and functional literacy skills that would enable them to understand and access healthcare services and know their rights

- Differences in cultural beliefs about personal health

- Low confidence, which prevents them from advocating for themselves or accessing health care when needed

- Restrictions on independence and dependancy on others to help them identify where and how to access health care

Settlement organizations offer health literacy in programs and services for immigrant women. Settlement workers often become advocates for immigrant women and connect them with same-language speakers to help them access appropriate healthcare services. There are settlement organizations across Canada, including Immigrant Services Association of Nova Scotia (ISANS), the Somali Immigrant Aid Organization (SIAO), and the Regina Open Door Society.

The services that the Immigrant Health Program at ISANS offers are listed below. Similar services, often in the native languages and cultures of the clients, are offered by settlement organizations across Canada:

- Evaluation of the healthcare needs of immigrants and their families

- Advocacy support for access to specialized healthcare services

- Orientation to the Canadian healthcare system, patient rights, and services and supports

- Connection to the Newcomer Health Clinic for access to family doctors and healthcare screening

Healthcare services such as Edmonton's New Canadians Health Centre are supported by immigrant-serving agencies in Edmonton such as the Mennonite Centre for Newcomers or the Multicultural Health Brokers Cooperative. The article The New Canadians Health Centre aims to help refugees thrive (Rutherford, 2022) describes in more detail how this centre supports immigrants and works with other immigrantsupport organizations to aid immigrant women and their families. The centre also offers opportunities to immigrant mental health professionals and former medical professionals who are not yet certified in Canada to work as volunteer cultural brokers for immigrants with the same language and cultural backgrounds.

The Primary Care Network (PCN) Mosaic Health Centre in Calgary has a similar goal. The centre offers supportive and culturally sensitive health care and mental health services to immigrants, most of whom are LFLL immigrant women. The centre also offers workshops to build health literacy in languages common to the clientele of the centre. 


\section{Strengths of Low-Literacy Adults}

According to well-known researcher and educator Jim Cummins (1980), there are two levels of competency in second-language acquisition (Cummins, 2016; Colorín Colorado, 2019):

- Basic Interpersonal Communication Skills (BICS) are language skills needed in social situations; that is, the day-to-day language needed to interact socially with people. BICS are the language learned in ESL classes and through interaction with English-language speakers.

- Cognitive Academic Language Proficiency (CALP) refers to the form of academic language learning related to higher-order thinking skills such as problem solving and conceptualizing, as well as professional language proficiency (PLP), or industry-specific language. This type of language is learned in academic, professional, or industry-specific settings.

BICS, or oral skills, are skills that most immigrant women with LFLL build quickly, even though their CALP skills take longer to develop. Therefore, immigrant women's oral skills develop much stronger and faster than their reading and writing skills. It is not uncommon for someone who has few to no foundational reading and writing skills in their native language or in English to master an intermediate level (CLB 4 or 5) of listening and speaking.

A low level of literacy is an obstacle that limits the potential for full participation in society, especially being able to secure stable and above-minimum-wage employment opportunities. The lack of literacy creates dependency on others who have a higher level of functional literacy and better English-language skills. In situations where the head of the family has little to no literacy, the oldest, first-educated child may become their link to the literate world.

\section{How Immigrant Women with Low Literacy Navigate the Literate English-Speaking World}

\section{What are the compensation strategies that LFLL immigrant women use?}

During the first stage of immigration, women who have limited English-literacy skills reach out to family, friends, and volunteers from religious and ethnocultural 
community settlement organizations to provide translation and interpretation. Reaching out to others is the initial survival strategy.

Children who learn language and literacy skills can soon become a link to the Englishspeaking literate world. Two stories are provided below. One story is from the 1960s, and the other is from 2014. The strategies are the same regardless of the time period, but when the basic factors are the same, a child's literacy progresses faster than the literacy of their parents. The first story is from a personal lived experience, and the second one is from a situation that was encountered by the Language Training Manager and Childcare Senior Manager at the Calgary Immigrant Women's Association (CIWA).

Learning Activity 2: Immigrant Women's Stories

Read the two stories below to prepare for the activity that follows.

\section{LFLL Immigrant Woman's Story I}

An Italian immigrant grandmother settled in Canada in the early 1950s with her husband, son, and daughter-in-law. The grandparents grew up in a time when education in rural Italy was not an obstacle for basic life skills in rural communities. The grandfather had never attended school, but the grandmother had. They came to Canada after the Second World War, when there was a significant influx of European immigrants. The family came from a wartime period when survival trumped education.

When the family arrived in Canada, they relied on relatives and the Italian community to establish housing and find employment. Access to English-language classes was not common at that time, and they did not see the need to learn English, other than what they picked up informally through social contact outside the home. Their limited literacy skills in their first language created dependence on 
the development of oral language skills. More importantly, it created dependence on those within their community of friends and relatives, because they required help to engage in complex tasks such as housing, health care, banking, and the paperwork needed for immigration, taxes, birth certificates for children, and so on. Once the first child born to the family entered public school and learned to speak, read, and write English, the dependence on others for interpretation and tasks that required literacy support changed from family and friends to their daughter, Angela. From the age of eight, Angela was expected to handle requests to read mortgage documents, fill out postdated cheques, translate at lawyer's offices, interpret at parent-teacher conferences, attend medical appointments, call utility companies to decipher bills and payments, accompany family members to the bank, and even sit with her grandfather on Sundays to teach him to read the Italian newspapers.

\section{LFLL Immigrant Woman's Story 2}

Sara is a refugee from Eritrea. She had no formal education because war and refugee camps took away her access to school. In 2014, Sara attended LINC classes five hours a day, four days a week at the immigrant settlement nonprofit organization where she was a client. She was placed in Literacy Level 1 (L1) in the LINC program, which is a pre-literacy level. Sara's oral skills were basic, but they were progressing faster than her reading and writing abilities. In her ESL literacy class, Sara learned how to use a writing tool to practise writing shapes, letters, and numbers. She progressed to writing her name, learning time conventions, and building basic numeracy skills in English. She developed decoding skills for letter-sound recognition that she applied to basic reading skills.

While Sara went to ESL class, her daughter Fatema was enrolled in the organization's childcare program. Fatema started at the 
childcare centre when she was one year old. Sara also accessed other support services and programs within the organization. Settlement workers and language professionals helped her to problem solve her day-to-day life skills challenges. Sara had a support system at the immigrant settlement organization that advocated for her and intervened on her behalf when she ran into life skills issues, such as reporting to Alberta Works for financial support, negotiating rent issues with landlords, filling out employment applications, and filling out subsidy forms for child care. All these fundamental life skill issues were a result of her lack of adequate literacy and language skills that consequently held her back from gaining independence.

Although Sara progressed slowly through her LINC program, her daughter, Fatema, quickly developed her oral and social skills at a pace that competed with her mother's progress. Sara often deferred to her daughter to speak English for her. One incident demonstrated Fatema's growing leadership skills-one of the activity centres was a dress-up centre with costumes representing different characters such as princesses, fairies, police officers, and firefighters. The children acknowledged that Fatema was the leader and gathered around her to wait for her direction. Fatema decided which child would wear which costume. She also decided the scenario that the children would play. She organized and directed her classmates through the game and the story that she created for them.

This story is relevant to this discussion because it shows how this balance of power showed up in the parent-child dynamics between Fatema and her mother. While her mother relied on the support systems around her, her daughter took the role of leader in the relationship. By the time Fatema was five years old, Sarah had started relying on her daughter to translate and navigate the literate world. It would be safe to predict that as Fatema matures and moves through the school system, her literacy and oral skills will surpass her mother's. Sara will most likely rely on her daughter as the first 
level of support and as the bridge between her and the complex literate society.

\section{Activity}

Select the best answers to each of the questions. More than one answer may be chosen.

\section{An interactive H5P element has been excluded from this version of the text. You can view it online here: \\ https://openeducationalberta.ca/settlement/?p=1434\#h5p-43}

\section{Reflection}

These stories about immigrant women with limited functional literacy skills are also about children who take on the role of translators and cultural brokers to connect their adult family members to the literate world. These two stories illustrate that although literacy learners are more likely to develop oral skills more quickly than literacy skills, it is the literacy or CALP skills that are needed to build independence in a literate world with complex life skills.

A relevant insight from a thesis, "Adaptation and Survival Strategies of Refugee Women with Disabilities In Saskatoon, Canada" by Florence Osei Poku (2018), shares the experience of LFLL immigrant women. The following excerpt from the thesis about the ESL class experiences of Ankita and Nadia demonstrate how confidence and independence grows from opportunities to learn English. These learning opportunities minimize the amount of dependency on translators such as their children:

Since the supervisors could speak their dialect, the women felt comfortable 
and trusted them with their documents. These services, however, were not always available. According to Ankita, "sometimes when I go to Open Door Society and the Global Gathering Place to see my supervisors about letters I have received and other government applications, they are sometimes busy or sick, but I need someone who is more committed." As a result, the women depended upon their children to serve as interpreters when other translators were not available. Nadia, for example, often relied on her daughter for translation services (Osei Poku, 2018).

Attending ESL classes is a real challenge for LFLL immigrant women because of their many family responsibilities, the pressures to work to contribute to the family, and the isolation in a community that is not supportive of the continuous learning of adult women.

The research of Geronimo, Folinsbee, and Goveas (2001) about the settlement needs of newcomers with low first language skills concludes that the essential purpose of acquiring language and literacy skills is to overcome basic survival skills:

Basic survival needs take precedence over the need to develop literacy skills, and as a result, the cycle of poverty, isolation, and lack of literacy skills becomes a common pattern if the basic survival needs of newcomers are not met (Geronimo, Folinsbee, \& Goveas, 2001).

\section{Digital Literacy}

The infiltration of digital literacy into the adult literacy matrix of the 21st century has complicated the range of required literacy that LFLL immigrant women are expected to incorporate into their learning. Basic literacy has added digital literacy to reading, writing, and numeracy. In his master's thesis, "Exploration of the Role of Digital Literacy in Refugee Migration and Resettlement" (2021), Manaal Nauman states:

For someone who may even be illiterate in their own mother tongue to learn a new language such as English, and then to also become educated in navigating the World Wide Web, can be overwhelming. Nowadays, technology has become the standard for many tasks that used to be done in person; for example, applying for jobs. Refugees and newcomers struggle with finding employment as they are unfamiliar with many technological advances in recruitment practices as "companies are increasingly moving toward the use of web-based hiring practices" (Novak, 2016, p. 293). The digital divide sometimes exists even within a family household of parents and children, a point emphasized by researchers highlighting children as "digital natives." 
In community ESL literacy programs, instructors incorporate learners' cellphones into their instruction. A story that is typical among the learners in ESL literacy programs is that of Hamza, a Somali woman who had a cellphone but did not know the cellphone's number. Her husband showed her which button to push to reach him in an emergency because she was not literate enough to read numbers and letters. The instructor used Hamza's cellphone to find her phone number, then Hamza used the numbers to practise forming numbers and to read, speak, and memorize the phone's number. Mastering a basic survival skill that involved technology was her first step to independence.

Learning Activity 3: Reflective Activity

1. Think of examples from real-life experiences with family members, community members, or clients that exemplify how adult literacy affects life skills.

2. Write out your thoughts in your learning journal. 


\section{The Relationship Between First-Language Literacy and the Settlement and Integration Challenges Faced by Immigrant Women}

Section-Specific Learning Objectives

By the end of this section, you should be able to

1. Identify the settlement and integration challenges faced by immigrant women

2. Analyze the challenges that immigrant women with low firstlanguage literacy (LFLL) experience when learning Englishlanguage and literacy skills

3. Describe the relationship between first-language literacy and the settlement and integration challenges faced by immigrant women

4. Identify the types of life-skill challenges faced by immigrant women with LFLL

5. Apply this learning to a reflective response activity

\section{Lack of Opportunity, Not Lack of Ability}

So far in this chapter, you have been introduced to several experiences of LFLL immigrant women and the challenges they have faced in confronting basic survival challenges. The contributing factors that lead to low functional literacy are not 358 | The Relationship Between First-Language Literacy and the 
products of the inability to learn or lack of intelligence. You can surmise from their stories that these women are resourceful and resilient in finding ways to face basic survival challenges despite low literacy. There are a number of interrelated factors that contribute to low first-language literacy of immigrant women in their home countries:

\section{No access to education}

Some cultures do not encourage or allow women access to education. Women from patriarchal cultures such as those in Pakistan, Iraq, South Sudan, and Afghanistan are not encouraged to fully participate in society in a manner equal to women in many other countries. Such societies dissuade a girl's or woman's desire to learn despite their aspirations.

\section{Interrupted education resulting from war}

War creates a refugee culture where safety, food, and shelter take priority over education. This is compounded by cultural and religious restrictions and limited opportunities for formal education.

\section{Oral culture}

Speaking a first language from an oral culture with no formal written language does not provide a reference point for learning a language that has a written system. Therefore, letter-sound recognition, decoding letters for reading, numeracy, and learning how to use a writing instrument are concepts and skills that are not innate to the learner.

\section{Age}

Older women may come from a generation when literacy was not as high a requirement as it is for women in later generations.

According to CIWA's presentation Low Literacy Employment Assessment Tools and Methodology for Immigrant and Refugee Women, some of the countries that immigrant women with low functional literacy may come from are Eritrea, Somalia, Ethiopia, Myanmar, Sudan, Iraq, Pakistan, and Afghanistan (caplatv, 2018).

UNESCO (2012) has established scorecards for countries that have the lowest literacy rate for women in an article, The bottom ten countries for female education. According to the country scorecard, Pakistan, Somalia, and Ethiopia are among the bottom 10 countries for educating women. For example, in Pakistan, where they celebrate Malala Day to commemorate the sacrifice made by Malala Yousafzai, an activist for female education, the poorest women aged 17 to 22 have on average attended only one year of schooling. 
The cultural barriers that discourage women's education in countries like Pakistan explain how this societal value, or lack of value for women's education, impacts women who come to Canada as immigrants. Culture more than religion dictates the devaluation of education. Patriarchal cultures do not see the value in investing in women's education because women's roles are to serve as wives, mothers, and homemakers, and not as leaders in their communities. A fundamental socio-cultural bias favours males in these cultures. This bias has an economic reason that supersedes socio-cultural reasons-the investment in a girl's education includes the cost of education tools such as books, uniforms, and study materials, but a girl's education does not add value to her marriageability. A girl's value is in her work in the home or in the field (Brock \& Cammish, 1997).

Cultural practices in South African rural groups are described in detail in the article 'Cultural' practices continue to force girls out of school: Time to act decisively by Relebohile Moletsane (2017). The article describes a skit by a group of women that plays out a common practice known as the "Coming Out Ball," a tradition in which young girls are chosen for marriage under the direction of their parents. Many women in this culture are familiar with this arrangement and have endured it because of patriarchal control over their choices. Dropping out of school to serve as a wife and to produce children is a young girl's fate in these cultures (Moletsane, 2017).

\section{Effects of War on Immigration}

War is another factor that adds to the challenges of LFLL immigrant women. War creates refugees who flee from a familiar country and culture in which they had an established identity and a familiar pattern to their lives. In their home society and culture, literacy skills may not have been an impediment to thriving, but when they are forced to flee to refugee camps and move to new countries, immigrants encounter societies that have a different standard of life and much higher literacy standards than the community in which they had originally established their lives. Imagine the added stress of finding themselves in a society where their ability to survive is compromised by their inadequate literacy and second-language skills.

\section{Did you know?}

In 2015, Kabul University launched a master's degree in Women

360 | The Relationship Between First-Language Literacy and the Settlement and Integration Challenges Faced by Immigrant Women 
and Gender Studies. Nonetheless, the country has one of the biggest education gender gaps.

According to UNICEF, girls accounted for $60 \%$ of the 3.7 million Afghan children who were out of school before the Taliban took over (UNICEF Afghanistan, n.d.).

In Afghanistan, only 37\% of teenage girls can read and write, compared to $66 \%$ of boys, according to Human Rights Watch. Government data suggests that one-third of girls are married by the age of 18 and nearly $9 \%$ by the age of 15 (Batha, 2022).

However, resilience is not lost but is built through adversity such as war. The TEDx Talk Why Children of Immigrants Work so Hard, by Colleen Bies, a child of immigrant/ refugee parents, reinforces the impact of strength despite adversity.

\section{How does low first-language literacy affect immigrant women when they come to Canada?}

\section{Perceptions of Immigrant Women with Low First-Language Literacy}

There are general stereotypes of immigrant women-they will do work that Canadians will not do, or they are security threats because of the political state and values of their countries of origin. Another stereotype is that they take jobs away from Canadians. A comprehensive report from the Canadian Research Institute for the Advancement of Women (CRIAW) (2003), Immigrant and Refugee Women, expands on these stereotypes and myths. The report discredits these stereotypes and highlights some significant contributions of immigrant and refugee women. The story of former Governor General Adrienne Clarkson (Jetelina, 2011) is one such immigrant story of success. There are many other stories of immigrant women who worked hard to support and advocate for their children's education.

The CRIAW report is a valuable resource to add to your understanding of how Integration Challenges Faced by Immigrant Women | 361 
immigrant women are perceived and how their stories break preconceived stereotypes.

Learning Activity 4: Reflective Activity

1. Reflect on what you have learned about the strengths and contributions of immigrant and refugee women, especially those who lack first-language literacy.

2. Write your observations in your learning journal.

\section{The Historical Struggle of Low First-Language Literate (LFLL) Immigrant Women}

What do LFLL immigrant women contribute economically and socially to Canadian society? While watching the TEDx Talk Migrant Women: Labels that Define Us, by Michele Levoy, reflect on the following:

- What stereotypes have historically defined immigrant and refugee migrant women?

- What are the similarities between the experiences of the presenter's grandmother and aunt?

- What are some of the ongoing challenges in the settlement of immigrant women across history?

- What are the similarities across stories that fuel immigrant women's drive to survive, to find security, and to invest in their children's future through work and sacrifice? 


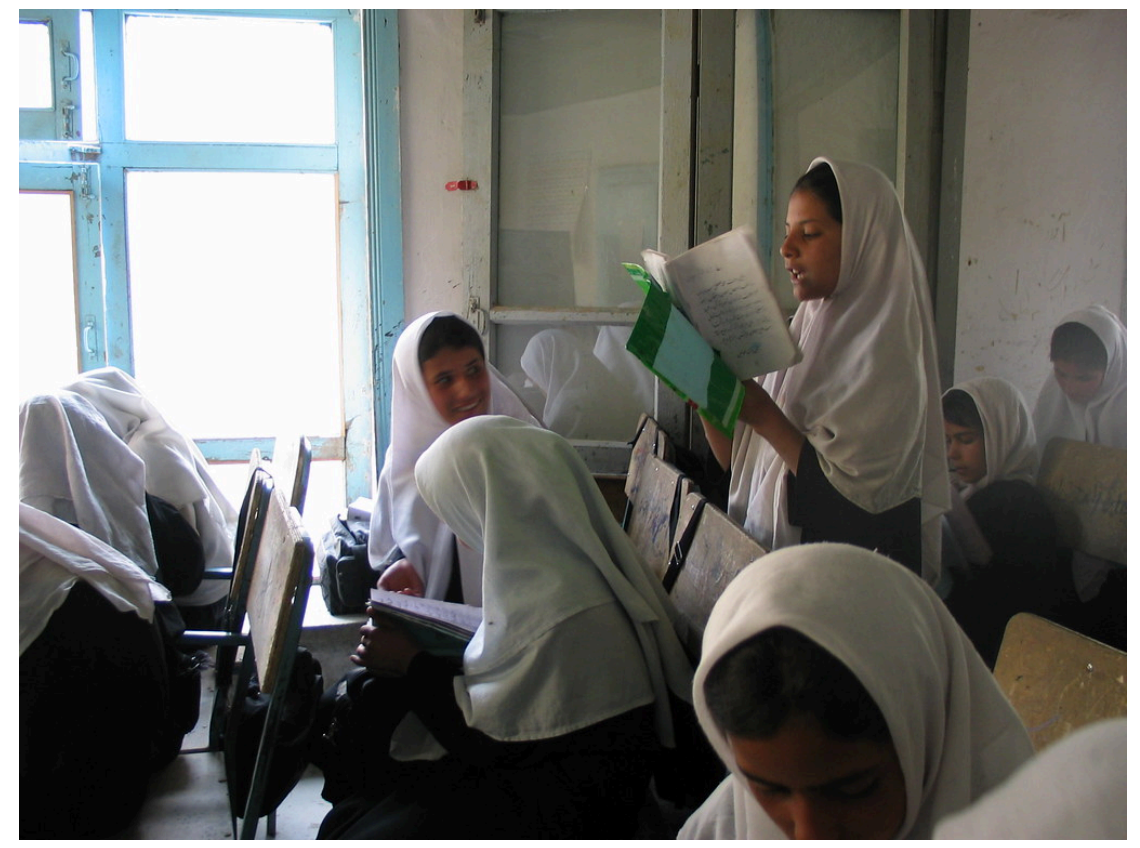

Teaching young girls to read in Afghanistan

Beyond the life skills challenges of housing, financial resources, food security, and accessing legal services and health and mental health services, having access to gender-specific services provides a safe environment that can alleviate the stress of sharing female-specific experiences with a man, especially when the women come from patriarchal cultures and countries. "Receiving services from women, being in a community with other women, is so empowering for them. The women's only environment is key to helping women become independent and make independent choices" (Bhuyan \& Schmidt, 2019).

Women supporting women is a service model that has been implemented by several organizations. Women-centred and holistic services can be found in organizations such as the Calgary Immigrant Women's Association (CIWA) Centre, Immigrant Women Services Ottawa (IWSO), and Newcomer Women's Services Toronto (NEW). Wraparound services literally "hug" a woman during her settlement journey. Support services and programs incorporate all areas of settlement in a safe, supportive, and familiar environment of women who are often immigrants themselves and have experienced and survived similar settlement challenges. These women-specific agencies offer programs and services that respond to all areas of settlement needs such as language training, family literacy, family service supports, mental health trauma-informed support, legal support, housing support, health literacy, employment training for all levels of functional literacy, and childcare support.

The Relationship Between First-Language Literacy and the Settlement and Integration Challenges Faced by Immigrant Women | 363 
The following is a reflection by a student, Ankita, taken from Florence Osei Poku's master's thesis, Adaptation and Survival Strategies of Refugee Women with Disabilities In Saskatoon, Canada (2018). Ankita's reflection on her learning experience highlights her growing independence and confidence because of taking English classes. Her improved English-language skills allowed her to communicate independently in a high-stakes situation without having to rely on another person:

I take English-language courses at the Global Gathering Place five times a week that is being sponsored by the government. The classes have helped me to express myself in English because I did not have much education and I do not know how to even write Arabic. My teachers are very good, patient, and understand that I am partially blind. They have been telling me I qualify to go to an upper level, but I do not want to because my current teacher understands my situation. When I got to the hospital and my translator comes in late, I can speak to the receptionist, so she knows I'm in for my appointment (Ankita, 2018, quoted in Osei Poku, 2018, p. 74).

\section{Learning Activity 5: Reflective Activity}

1. Identify scenarios in which immigrant woman encounter challenges in Canada.

2. Identify what these women will need to support them in their integration process.

3. Write your observations in your learning journal.

Image Credit

Teaching Young Girls to Read by Canada in Afghanistan, CC BY-NC-ND 2.0

364 | The Relationship Between First-Language Literacy and the Settlement and Integration Challenges Faced by Immigrant Women 


\section{Theories, Strategies, and Settlement Models that Support Immigrant Women with Low First-Language Literacy (LFLL)}

Section-Specific Learning Outcomes

By the end of this section, you should be able to

1. Describe or outline theories and strategies that identify the settlement challenges of immigrant women

2. Identify successful program models implemented by community groups and settlement agencies to support immigrant women with LFLL

3. Describe the benefits of the strategies and program models implemented by educational and settlement sectors to support immigrant women with LFLL

4. Apply these learnings to create a reflective response for this topic

\section{What is the importance of adult literacy?}

Watch Why 36 million American adults cannot read enough to work - and how to help them (PBS NewsHour, 2019). Although the video does not represent immigrant women, it demonstrates the importance of adult literacy and the challenges that are universal in a literate society. 


\begin{tabular}{|l|}
\hline Did you know? \\
Hilary Clinton \\
brought the HIPPY \\
program to \\
Arkansas in 1986. \\
Watch this video \\
to find out more \\
about this early \\
literacy program \\
that supports both \\
parent and child \\
literacy.
\end{tabular}
information and education about the services that are available to meet the unique needs of each family.

Community ESL literacy programs focus on recruiting families from communities known to have high numbers of low-literacy and low-income immigrant families. These high-risk, vulnerable families often experience a great deal of isolation in the community.

Many families are unfamiliar with available services and resources in their communities, and as such, they are unable to get the support they need. By focusing recruitment on specific communities, Early Family Literacy programs help lowincome immigrant families gain skills and knowledge about resources to help themselves move out of poverty. In these programs, children of immigrant families receive guidance and support to help with school readiness and stand a better chance of integrating into the community and achieving positive results in school. Through group meetings, families connect with other parents living in their communities and learn about resources. The overall integration process for the families involved in these programs becomes less intimidating, they access resources and services, and their children successfully transition from a single cultural environment at home into the Canadian community and school culture.

366 | Theories, Strategies, and Settlement Models that Support Immigrant Women with Low First-Language Literacy (LFLL) 


\section{Social Capital and Immigrant/Refugee Women}

Social capital is an individual's ability to interact with others and contribute to their social group by sharing similar values and individual practical and problem-solving skills that contribute to the betterment of their social network.

It is difficult for LFLL immigrant women to gain social capital because of their limited literacy and English-language skills. English-language and literacy classes provide these women with skills that in turn lead to self-sufficiency, independence, and opportunities to give back to society instead of leaning on the support of translators, family, community, and grown children to navigate day-to-day survival and settlement.

The list below is a summary of the goals of Canadian settlement services and programs that support LFLL immigrant women and focus on developing learners' literacy for life skills:

- Networks

- Belonging

- Safety

- Reciprocity

- Participation

- Citizen power

- Values-led living

- Diversity

The program models are designed to give LFLL immigrant women agency in their own lives to move beyond dependency to independence.

\section{Civic Engagement Programs}

Civic engagement programs help promote and enhance the quality of life in a community and can include political activism, environmentalism, and community services. An example such a program is the Civic Engagement for Immigrant Women Program offered by the Calgary Immigrant Women's Association (CIWA). This type of program helps immigrant women and girls achieve full and equal civic participation in Canada.

Immigrant women and their families receive civic education through activities that present an overview of Canada's government structure and offer support for them to exercise their civic duties in Canada, such as taking the citizenship exam and voting.

Theories, Strategies, and Settlement Models that Support Immigrant Women with Low First-Language Literacy (LFLL) | 367 
Program manuals are available in the following languages: English, Spanish, French, Hindi, Farsi, Arabic, Mandarin, Cantonese, Polish, Russian, Tigrinya, and Korean. However, support is available for those who have trouble with first-language literacy. As always with programs that serve immigrant women, child care is available.

\section{Community-Based ESL Literacy Programs}

From 1986 to 1992, the Calgary Board of Education ESL department received Alberta Initiative funding to offer a community-based ESL program that reached out to immigrant women who were primarily refugees from South America, Vietnam, Cambodia, and Chile. Called Stepping Out, the target group profile was refugee immigrant women from rural areas who had low first-language literacy.

The program model consisted of three phases and transition points:

- Phase 1 - Home instruction with first-language tutors. Introduction to Canadian society and adaptation to life skills supported immigrant women who were recent arrivals and needed transitional support from a tutor who spoke a common language.

- Phase 2 - Community-based classes in church basements, community centres, and student homes that were within walking distance of immigrant women. Free child care was provided that also provided literacy education for children. Foundational literacy and English for settlement and life skills was the focus of the language training.

- Phase 3 - Transition to traditional classroom ESL programs that were more academic and workplace focused.

Stepping Out was successful in helping immigrant women with low foundational literacy to develop their literacy and English skills in a safe, supported environment that started in their homes and transitioned to more independent learning as their confidence and skills increased. This program model influenced other types of community-based ESL programs that accommodated women who would not reach out independently to ESL classes because of their lack of confidence and awareness of these opportunities. Immigrant women were contacted through direct community, including the most basic and direct form of outreach-door to door. First-language tutors knocked on doors in immigrant neighbourhoods to promote the classes and offer to come to students' homes to teach for one to three months, and then help the students transition to community classes.

Another program that supports the English language and literacy development of LFLL immigrant women, is CIWA's Pebbles in the Sand program. The program grew out

368 | Theories, Strategies, and Settlement Models that Support Immigrant Women with Low First-Language Literacy (LFLL) 
of the Stepping Out program. Participants are immigrant and refugee women who often come from remote rural areas of the world or from countries that have been affected by political unrest or war (for example, Sudan, Afghanistan, and Pakistan). For these women, living in Calgary is their first experience in an urban environment. Upon entering Canada, many remain isolated in their homes because of a lack of English communication ability, literacy skills, and fear and trepidation about the unfamiliar environment and culture.

These women face multiple learning barriers including age, learning disabilities, attitude towards education, difficult family situations, health impediments, and low self-esteem. The highest percentage of program participants $(90 \%)$ are women with no previous education, no English-language skills, and no literacy skills in their first language. These obstacles keep them economically and socially disadvantaged in society.

Watch this YouTube video to hear the perspectives of ESL instructors who work with low-literacy immigrant women: Teaching Literacy Learners: A Conversation with Instructors from "Pebbles in the Sand" (CIWA) (Literacy Centre of Expertise, 2022).

\section{The Somali Women and Children's Support Network}

Another example of a non-profit immigrant settlement organization is the Somali Women and Children's Support Network in Toronto, Ontario. It is a multicultural, nonprofit, community-based organization that provides services to immigrant women and children with the intent to help women develop leadership skills and move from dependency to self-sufficiency. The organization offers programs and services that help women develop self-sufficiency skills to be able to connect to "mainstream" services with support from the community.

\section{Learning How to Learn}

Paulo Freire's participatory approach to language learning (HW, 2007) encourages learners to take control of their learning by participating in the evolution of a program's curriculum and dialogue with the instructor or facilitator about their learning needs; the learner is also seen as an educator. The previous experiences and knowledge that each adult learner brings to the classroom adds value to the learning experience of others, including the instructor. This process and approach are 
used in the life skills, job-shadowing debriefing, cultural competency, and networking components of this type of program model.

\section{How is Freire's philosophy applied in community-based ESL literacy programs?}

Freire's philosophy (Freire, 1970) supports a learning model that develops the social capital of immigrant women who have been isolated from society because of their limited communication and literacy skills. This model enables learners to take charge of their lives by encouraging problem solving, critical thinking, and goal setting. The development of critical consciousness (Kayser \& Starks, 2021) is an ambitious but attainable goal in addition to the development of practical language, literacy, and life skills.

The following three approaches to learning support Freire's philosophy of participatory education:

1. Teachers and students learn from each other, and learning is a collaborative process. Students identify what they need to learn English for; they address their immediate needs. Teachers support the learning with resources that are authentic and relative to the everyday needs of the learners.

2. Implementing active-enquiry strategies in the learning process encourages learners to question what they are learning, why they are learning, and how they will benefit from what they are learning. This critical reflection gives learners a voice for discussing and understanding how their world will be improved through learning the functional literacy skills that will improve their independence and self-reliance.

3. Developing critical literacy strategies is as important as functional literacy skills such as reading, writing, and numeracy. These skills are viewed as passports to critical literacy.

These three ways of applying Freire's philosophy are summarized in his book, Pedagogy of the Oppressed (1970), and are the basis of the models used in community-based ESL literacy programs.

The tools used in these programs allow learners to determine their goals beyond basic survival and work identified in Maslow's Hierarchy of Needs (Serhat, 2020), ranging from physiological and safety needs to love and belonging in their adopted culture to esteem and self-actualization (Hopper, 2020). 


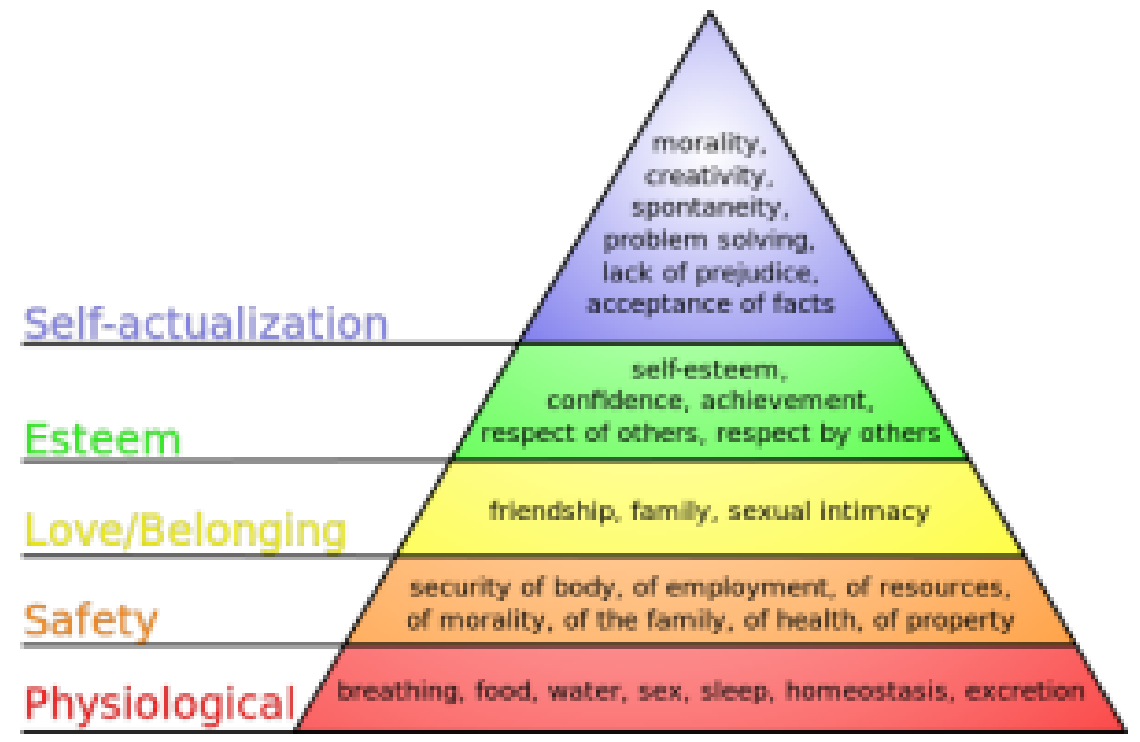

Maslow's Hierarchy of Needs

\section{Biliteracy Program Strategies}

Two approaches to using biliteracy development have demonstrated that providing foundational literacy in a person's first language is a strategy that will develop foundational literacy skills that can be subsequently transferred to learning a second language.

The Calgary Chinese Community Services Association's Stepping Stone ESL Program for low-literacy Chinese learners uses an ESL first-language facilitator to build firstlanguage literacy as a bridge to literacy skills for English-language learning. The firstlanguage facilitator works in collaboration with the ESL instructor to decode and decipher English-language concepts that interfere and stall the progress of learning new English vocabulary and functions. Language and literacy instruction is taught in the context of the life-skills goals identified by learners. Learners recognize the value of computer-literacy training in addition to English and literacy skills because they are very aware that digital literacy is an essential skill that will help them become more independent.

An initiative that explored the bilingual literacy strategy for LFLL immigrant women is a research project by the CanLearn Society that produced a curriculum framework for biliteracy education (CanLearn, 2021). The rationale and strategies behind this 
framework are to teach first-language literacy skills alongside English-language literacy skills. This approach facilitates a learner's ability to transfer literacy skills developed from a familiar reference point to learn English as a second language. The resources used to teach foundational literacy have been developed for Farsi, Nepali, and Tigrinya. This research project would be worth exploring for English-language training, and bilingual education methodology may be increasingly adopted in secondlanguage practices to advance the development of literacy skills for LFLL immigrant women.

Learning Activity 6: Reflection Activity

1. Review theCanLearn research project A Curriculum Framework Biliteracy Learning with Adult ESL Literacy Learners.

2. Reflect on two pros and two cons of implementing a biliteracy learning approach into an ESL language class.

3. Write your observations in your learning journal.

Image Credit

Maslow's Hierarchy of Needs by $\underline{\text { J. Finkelstein, CC BY-SA 3.0 Unported }}$ 


\section{Summary and Conclusions: The Evolution of Strategies for Low First-Language Literacy (LFLL) Women in Canada}

Section-Specific Learning Outcomes

By the end of this section, you should be able to

1. Summarize the evolution of strategies for LFLL women in Canada

2. Describe or outline what strategies support successful program models

3. Apply learnings from this chapter to offer solutions to case studies of immigrant women with LFLL

\section{Beneficiaries of Resilience}

In the process of researching and writing this chapter, there were minimal resources and limited research related to the experiences of immigrant women in Canada who have low first-language literacy skills. The Canadian Ranking System, also known as the Immigration Point System, favours immigrants with higher English-language skills and higher education and professional skills (Government of Canada, 2021). The C.D. Howe Institute publication, The Power of Words: Improving Immigrants' Literacy Skills (Mahboubi, 2017) identifies in their study of the literacy skills of immigrants who apply to come to Canada that refugees have the highest literacy-skills gap (compared to non-immigrants) at 44\% (see Figure 1: Literacy-skills Gap Between Canadian Immigrants and Non-immigrants by Program, p. 6). The lowest literacy-skills gap is 
in the Economic (12\%) and Other (10\%) categories (Mahboubi, 2017, p. 6). Those who come through the point system in the Economic category make up $12 \%$ of the overall immigration category. Most LFLL immigrant women come as refugees. Their high literacy skills gap makes it difficult to contribute to the economy of Canada as quickly and effectively as those with higher English, education, and professional skills.

LFLL immigrant women find themselves in low-paying service jobs where language is not a primary requirement. Positions as cleaners and maids, and labour jobs that most likely pay minimum wage or less and are not secure are the fate of immigrant women in this low-literacy category. If not working, these women are typically isolated at home and are responsible for taking care of the home, family, and children. Prospects for learning and improving their independence and quality of life are limited. These are the women that immigration and community settlement organizations have forgotten. Most of the funding from the Canadian government is for programs that promote more skilled and better-educated immigrants and refugees to prepare them for the workplace or post-secondary education.

So, what is the value of LFLL immigrant women? They are the caretakers of the family, they allow children to succeed in education and work, and they may even be the caretakers of their grandchildren. They keep the culture and values alive in their families. They take the menial jobs that others rush to leave for better positions. They are the thread that keeps the family together. Fortunately, non-profit organizations are moving beyond conversation clubs and informal language programs to developing and offering ESL workplace and literacy training programs. These program models give LFLL immigrant women opportunities to realize their potential and advance their personal and financial situations.

In this last section of the chapter, challenge yourself to see the value in supporting the education of LFLL immigrant women. After reviewing the chapter sections, resources, and videos, reflect on the following questions:

- What do you think is the value of combining adult and child literacy in early literacy programs?

- Which program models and services would best support immigrant women with low literacy to successfully settle in Canada?

- Do you think that a biliteracy language approach would lead to success? What do you think would be the challenges of implementing this methodology in ESL literacy classes?

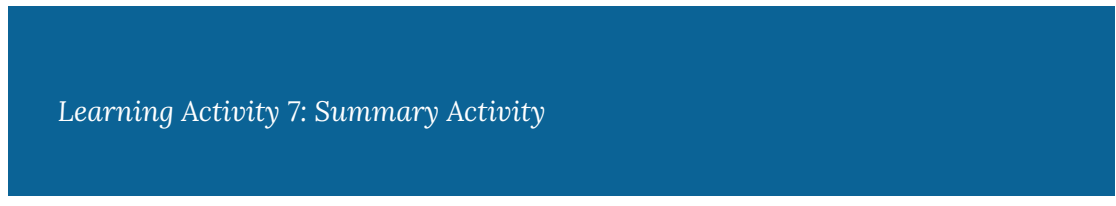

374 | Summary and Conclusions: The Evolution of Strategies for Low First-Language Literacy (LFLL) Women in Canada 
The following stories are based on those in the Centre for Canadian Language Benchmarks (CCLB) publication, ESL for ALL (CCLB, 2022). The stories are representative of many immigrant women with LFLL who struggle with literacy and English-language skills.

Choose one of the stories below of immigrant women with LFLL. Based on the programs, strategies, learning challenges, and needs presented in this chapter, answer the following questions:

- What do you think were the underlying causes of the woman's low literacy skills?

- Do you think that she would be able to progress to a higher level of literacy?

- What are the skills and strengths that she brings to her Canadian settlement experience?

- How do you think her low literacy and low English-language skills affect her ability to achieve independence and become part of Canadian society?

- What are the strategies that you think she is using to overcome her low literacy skills?

- Which programs and services do you think would help her overcome the limitations of low literacy and English?

\section{Learner 1: Aiesha}

Aiesha is from Yemen. She had six years of education in her home country and has been in Canada for eight years. Her learning has been interrupted by civil war and family demands. With her family's help she manages the family finances. She also works full time as a janitor at a local school and goes to English class four nights a week.

When she started her English studies in Canada she was assessed at Listening CLB 3, Speaking CLB 3, Reading CLB 1L, and Writing Pre-Benchmark L (Foundation). She was placed in a supportive ESL Literacy class where she has developed a good relationship with her classmates. She enjoys group 
work, particularly when she has a chance to share her experiences of living and working in Canada. She has some difficulties with grammar but knows how to express her ideas and opinions. She is a good listener who politely listens to different opinions.

Aiesha knows how to use prediction strategies to help her read simple documents like forms and posters. She also knows how to ask for help when she needs it and regularly asks her instructors to check her work. She is learning where to find information and how to use her ID to complete simple forms. She struggles with reading and writing but can recognize patterns in spoken English. She has a bank of sight words, which she sometimes confuses. She needs to improve her sound-letter correspondence and her word recognition strategies to help decipher unfamiliar words.

Aiesha has trouble changing quickly from one task to another. Although her math skills are good, she finds it hard to locate information on a receipt or bill. She has basic Word skills but struggles to use the internet, even with help. Despite her busy schedule with work and family, Aiesha is a highly motivated learner who wants to improve her English so she can have a better life in Canada. She wants to become more independent, find a better job, and support her children in reaching their goals.

\section{Learner 2: Shakira}

Shakira is from a small village in Afghanistan, where education for girls was not permitted. At 18, she entered an arranged marriage, then she and her husband fled to Pakistan to escape war. While there, they had four children, but her life changed dramatically after her husband passed away suddenly. To support her family, she worked as a cleaner, and after several years, she immigrated to Canada with her children. 
Shakira is now in her second year of ESL literacy classes. Prior to taking these classes, she had no English or literacy skills. She enjoys her courses and often arrives early to socialize with her classmates. She also likes the English program volunteers and always greets them warmly. At home, she loves to cook and take care of the three children still living at home.

Shakira is a highly motivated student and rarely misses a class. Her favourite activities in class are playing games and doing quizzes. During class, she works well independently but also likes group work. Her speaking skills are good, and she is developing an awareness of structure. She writes slowly because she hates making mistakes. She often spells and reads aloud. Shakira's instructors are encouraging her to transfer her learning to her home and community because her children often need to do things for her. She is the only person in her class who speaks Dari. 


\section{Chapter References and Attributions}

\section{References}

ABC Life Literacy Canada. (2022). Literacy at a glance. https://abclifeliteracy.ca/ literacy-at-a-glance/

Batha, E. (2022, March 25). Afghanistan: What will happen to girls' education under Taliban rule? Global Citizen and Thomson Reuters Foundation. https://www.globalcitizen.org/en/content/afghanistan-girls-education-talibanwhat-happens/

Bhuyan, R., \& Schmidt, C. (2019). Immigrant women's settlement transitions in an era of precarious migration: Primary research report. Immigrant Women, Youth and Seniors (IWYS). https://ocasi.org/sites/default/files/iwys-primary-research-womensfinal-report.pdf

Brock, C., \& Cammish, N. (1997). Factors affecting female participation in education in seven developing countries (2nd ed.). Education Research Paper No. 9. Department for International Development. https://files.eric.ed.gov/fulltext/ED411432.pdf

Brookfield, S. D. (1986). Understanding and facilitating adult learning: A comprehensive analysis of principles and effective practices. Jossey-Bass.

Calgary Chinese Community Service Association (CCCSA). (2022). English literacy. https://cccsa.ca/english-literacy/

Calgary Immigrant Women's Association (CIWA). (2022a). Civic engagement for immigrant women program. https://ciwa-online.com/newcomer-services/ parents-seniors-youth/civic-engagement-for-immigrant-women-program/

Calgary Immigrant Women's Association (CIWA). (2022b). Pebbles in the sand. https://ciwa-online.com/newcomer-services/language-and-literacy/pebbles-inthe-sand/

Calgary Immigrant Women's Association (CIWA). (2017a). Assessment tools for skills, needs and progress of ESL literacy learners. https://www.informationcommons.ca/ resources/language-and-literacy/assessment-tools-for-skills-needs-andprogress

Calgary Immigrant Women's Association (CIWA). (2017b). Identifying skills and addressing the gaps for struggling ESL literacy learners: An action research project 
summary

report. https://www.atesl.ca/documents/1532/CIWA-

summary report.pdf

Calgary Immigrant Women's Association (CIWA). (1999). Knowing your literacy students project: Curriculum guidelines and cultural manual. http://en.copian.ca/library/ learning/ciwa/kyls project/kyls project.pdf

Canadian Research Institute for the Advancement of Women (CRIAW). (2003). No. 5: Immigrant and refugee women. https://www.criaw-icref.ca/wp-content/uploads/ 2021/04/Immigrant-Refugee-Women-Factsheet.pdf

CanLearn Society. (2021). A curriculum framework biliteracy learning with adult ESL literacy learners. https://www.canlearnsociety.ca/wp-content/uploads/2021/07/ A-Biliteracy-Curriculum-Framework.pdf

caplatv. (2018, January 31). Low literacy employment assessment tools and methodology for immigrant and refugee women [Video] YouTube. https://www.youtube.com/ watch?v=7NDrxnjXoGs\&t=2256s

Centre for Canadian Language Benchmarks (CCLB). (2022a). ESL for adult literacy learners (ALL). https://www.language.ca/product/pdf-e-020-clb-esl-for-all/

Centre for Canadian Language Benchmarks (CCLB). (2022b). Home page. https://www.language.ca/home/

Clinton, H. (2016, May 9). HIPPY program: supporting children and working families since 1985 | Hillary Clinton [Video]. YouTube. https://www.youtube.com/ watch?v=C2qfOwpQv7U\&ab_channel=HillaryClinton

Colorín Colorado! (2019). What are BICS and CALP? https://www.colorincolorado.org/ faq/what-are-bics-and-calp

Cummins, J. (2016). Reflections on Cummins (1980), "The cross-lingual dimensions of language proficiency: Implications for bilingual education and the optimal age issue. TESOL Quarterly, 50(4), 940-944. https://onlinelibrary.wiley.com/doi/10.1002/ tesq.339

Cummins, J. (1980). The cross-lingual dimensions of language proficiency: Implications for bilingual education and the optimal age issue. TESOL Quarterly, 14(2), 175-187. https://www.jstor.org/stable/3586312?origin=crossref

Freire, P. (1970). Pedagogy of the oppressed (M. Bergman Ramos, Trans.). Herder \& Herder.

Geronimo, J., Folinsbee, S., \& Goveas, J. (2001). A research project into the settlement needs of newcomers with low literacy skills in their first language who have settled 
in the GTA. Canadian Multilingual Literacy Centre. http://atwork.settlement.org/ downloads/settlement needs first language literacy skills.pdf

Government of Canada. (2021). Immigration and citizenship: Comprehensive ranking system (CRS): skilled immigrants (express entry). https://www.cic.gc.ca/english/ immigrate/skilled/crs-tool.asp

HW. (2007, September 25). Paulo Freire's participatory model. North American Congress on Latin America (NACLA). https://nacla.org/article/paulo-freire\%27sparticipatory-model

Hopper, E. (2020, February 24). Maslow's hierarchy of needs. ThoughtCo. https://www.thoughtco.com/maslows-hierarchy-of-needs-4582571

iCAMS. (2008). LINC students: Table A-4: Discrete LINC clients in 2008. Government of Canada. https://www.canada.ca/en/immigration-refugees-citizenship/ corporate/reports-statistics/evaluations/language-instruction-newcomerscanada-2010/appendixa.html

Immigrant Services Association of Nova Scotia (ISANS). (2021). Home page. https://isans.ca

Immigrant Women Services Ottawa (IWCA). (2022). Home page. https://www.immigrantwomenservices.com

Immigration, Refugees and Citizenship Canada (IRCC). (2022). Settlement program: Terms and conditions. Government of Canada.https://www.canada.ca/en/ immigration-refugees-citizenship/corporate/transparency/program-termsconditions/settlement.html

Immigration, Refugees and Citizenship Canada (IRCC). (2021). Language training options for newcomers to Canada [Video]. Government of Canada. https://www.canada.ca/en/immigration-refugees-citizenship/news/video/ language-training-options.html

Immigration, Refugees and Citizenship Canada (IRCC). (2011). Evaluation of the Language Instruction for Newcomers to Canada (LINC) program: Appendix A: LINC - A statistical portrait. Government of Canada. https://www.canada.ca/en/ immigration-refugees-citizenship/corporate/reports-statistics/evaluations / language-instruction-newcomers-canada-2010/appendixa.html

Jetelina, M. (2011, May 19). From refugee to Governor General. Canadian Immigrant. https://canadianimmigrant.ca/people/from-refugee-to-governor-general

Kayser, A. A., \& Starks, T. (2021, December 14). What is critical consciousness? 
Understanding sociopolitical consciousness in the classroom. Achieve the Core. https://achievethecore.org/peersandpedagogy/what-is-critical-consciousness/

Knowles, M. S. (1984). Andragogy in action: Applying modern principles of adult education. Jossey-Bass.

Lake, D., \& Watt, D. (2014). Benchmarking adult rates of second language acquisition $\mathcal{E}$ integration: How long and how fast? Final report 2004. https://www.researchgate.net/profile/David-Watt-10

Literacy Centre of Expertise. (2022, January 11). Teaching literacy learners: A conversation with instructors from "Pebbles in the sand" (CIWA) [Video]. YouTube. https://www.youtube.com/watch?v=jcev48IMLso\& $\mathrm{t}=42 \mathrm{~s}$

Mahboubi, P. (2017). The power of words: Improving immigrants' literacy skills. Commentary No. 486. C. D. Howe Institute. https://www.cdhowe.org/sites/ default/files/2021-12/Commentary 486.pdf

Malala Fund. (2022). Malala's story. https://malala.org/malalas-story/

Moletsane, R. (2017, March 7). 'Cultural' practices continue to force girls out of school: Time to act decisively. Brookings. https://www.brookings.edu/blog/educationplus-development/2017/03/07/cultural-practices-continue-to-force-girls-outof-school-time-to-act-decisively/

Mothers Matter Centre. (2019). HIPPY Calgary at Calgary Immigrant Women's Association. $\quad$ https://mothersmattercentre.ca/hippy-calgary-at-calgaryimmigrant-womens-association-ciwa/

Mosaic Primary Care Network (PCN). (2022). Programs \& services. https://mosaicpcn.ca/programs/

Nauman, M. (2021, August 29). Exploration of the role of digital literacy in refugee migration and resettlement [Master's thesis, University of Alberta]. https://era.library.ualberta.ca/items/09749522-3b5f-4d33-b9d7-8a65ec96dd8e/ download/ba357d48-a466-4e6d-bd4a-50eb43cd7b36

New Canadians Health Centre (NCHC). (n.d.). Home page. https://nchcedmonton.org/

Newcomer Welcome Centre. (2022). Home page. Regina OpenDoor Society. https://rods.sk.ca/pages/newcomer-welcome-center

Newcomer Women's Services Toronto. (2020). Home page. https://www.newcomerwomen.org

Organisation for Economic Co-operation and Development (OECD). (n.d.). Canada. https://www.oecd.org/canada/ 
Osei Poku, F. (2018). Adaptation and survival strategies of refugee women with disabilities in Saskatoon, Canada [Master's thesis, University of Saskatchewan]. https://harvest.usask.ca

PBS NewsHour. (2019, June 11). Why 36 million American adults can't read enough to work - and how to help them [Video]. YouTube. https://www.youtube.com/ watch?v=6N8EYkepuqQ

Programme for the International Assessment of Adult Competencies (PIAAC). (n.d.). OECD skills surveys: Survey of adult skills (PIAAC). Organisation for Economic Cooperation and Development (OECD). . https://www.oecd.org/skills/piaac/

Regina Open Door Society. (2022). Newcomer welcome centre. https://rods.sk.ca/ programs/settlement/nwc/

Rockall-Schmidt, G. (2021, September 24). Endemic illiteracy [Video]. YouTube. https://www.youtube.com/watch?v=ussd7JNVihA

Rutherford, G. (2022, March 09). The New Canadians Health Centre aims to help refugees thrive. Folio (University of Alberta). https://www.ualberta.ca/folio/2022/ 03/the-new-canadians-health-centre-aims-to-help-refugees-thrive.html

Serhat, K. (2020, February 6). Maslow's hierarchy of needs in education. Education Library. https://educationlibrary.org/maslows-hierarchy-of-needs-in-education/

Somali Immigrant Aid Organization (SIAO). (2022). Home page. https://siao.ca/

Somali Women and Children's Support Network. (2022). Home page. https://www.somaliwomenandchildrensupportnetwork.com/

Statistics Canada. (2022). Programme for the International Assessment of Adult Competencies (PIAAC). Government of Canada. https://www23.statcan.gc.ca/imdb/ p2SV.pl?Function $=$ getSurvey\&SDDS $=4406$

Statistics Canada. (2015). Literacy - Descriptions of proficiency levels. Government of Canada. https://www150.statcan.gc.ca/n1/pub/89-555-x/2013001/t/ tbl1.1-eng.htm

TEDx Talks. (2016, November 29). Migrant women: labels that define us | Michele Levoy | TEDxBrusselsWomen [Video]. YouTube. https://www.youtube.com/ watch?v=F3abYkPKmWI

TEDx Talks. (n.d.). Why children of immigrants work so hard | Colleen Bies | TEDxOshkosh [Video]. YouTube. https://www.youtube.com/watch?v=91RUVfFGVxQ

United Nations Educational, Scientific, and Cultural Organization (UNESCO). (2012, November 09). The bottom ten countries for female education. GEM Report. 
https://world-education-blog.org/2012/11/09/the-bottom-ten-countries-forfemale-education/

United Nations Educational, Scientific, and Cultural Organization (UNESCO) Institute for Statistics. (2022). Literacy: Definition. http://uis.unesco.org/en/glossary-term/ literacy

UNICEF Afghanistan. (n.d.). Education. https://www.unicef.org/afghanistan/ education

World Health Organization (WHO). (1998). Health promotion glossary. file:///Users/ njcarriere/Downloads/WHO_HPR_HEP_98.1.pdf 



\section{CHAPTER 8: "TOO HOT TO HANDLE" - HUMAN MIGRATION ON A RAPIDLY WARMING PLANET}





\title{
Introduction
}

\author{
ALEXANDRU CALDARARU
}

\section{Introductory Remarks}

It may seem strange to be discussing the concept of climate change in a resource that explores best practices for supporting immigrants and refugees with the transition to life in Canada. However, the current state of affairs in our world requires settlement workers to envision the links between two of the most acute crises currently affecting our planet, crises that at first glance are seemingly unconnected-the climate crisis, and the global refugee crisis.

Before exploring the connections between these two phenomena in greater detail, it's important to recognize that the term "crisis" is not one to be used lightly. Many have suggested that repeated use of the word "crisis" to describe every instance of political, social, economic, and/or environmental instability robs the word of its power (Bures, 2020). Nevertheless, Mukheibir and Mallam (2019) argue that there are characteristics of crises that distinguish them from other types of emergencies.

In short, a crisis is a critical situation that has arrived at a tipping point and has three distinct characteristics (Everbridge, n.d.). First, a crisis involves a situation that has never been encountered before, so has no mitigation plan in place. Second, even if the event is familiar, a crisis situation is one that occurs at a speed or frequency that hinders the development of an effective mitigation plan. Finally, a crisis may involve a combination of multiple forces that collectively comprise a situation that is distinct (and therefore difficult) to manage (Phelps, 2019).

Whereas climate change can be defined as the change in average conditions (such as temperature or precipitation) experienced by a place over a long period of time, the pace of change has dramatically increased over the past 300 years (David Suzuki Foundation, 2022). The vast majority (97\%) of climatologists have further concluded that the escalation of climate change over the past century is a direct result of human activities (NASA, 2022; Cook et al., 2016, p. 2). As a result, an increasing body of literature has emerged suggesting that the world is entering a period of climate crisis that is impacting global food production, disrupting national economies, and fuelling social unrest (Guterres, 2019; United Nations, n.d.b).

In addition, our world is in the midst of its largest epidemic of forced migration on record, one that shows no signs of abating any time soon. The United Nations High Commissioner for Refugees (UNHCR) has estimated that by the midpoint of 2021, 
more than 84 million people will have been forcibly displaced worldwide (UNHCR, 2022b)-a number that undoubtedly will have risen as a result of the outbreak of hostilities in Ukraine in early 2022 (NPR, 2022). This number has effectively doubled in the past decade, and currently represents one out of every 97 people in the world (Abdullah, 2022). The escalating severity of the problem has caused leading humanitarian organizations from around the globe to refer to this phenomenon as the global refugee crisis (Facing History \& Ourselves Collective, n.d.).

Settlement workers can make valuable contributions to conversations about climate change and migration. As will be discussed below, the twin global climate and refugee crises cannot continue to be viewed in isolation from one another. Their intersections represent the next frontier of human migration on our planet, and if Canada's settlement sector is going to meet the challenges presented by these migration patterns of the future, an evolution of how we conceive of forced human displacement is going to be necessary.

Specific Learning Outcomes

By the end of this chapter, you will be able to

1. Define the terms climate crisis, global refugee crisis, and environmental/climate refugee

2. Describe how Canada's refugee system currently operates

3. Discuss major international accords and protocols on human migration of which the Government of Canada is a signatory

4. Explain the impact of the Earth's changing climate on contemporary global migration patterns

5. Develop strategies for advocating for the recognition (and inclusion) of environmental/climate refugees in policies and programs that support newcomers to Canada 
INSTRUCTOR NOTE: Although this activity can work well as an individual activity followed by a large group discussion, it could be combined with Learning Activity 5 (where learners are asked to do the same quiz again). It would also work well as an online discussion forum topic.

LEARNER NOTE: Keep this list handy because the same questions will be asked of you again at the end of this chapter.

On your own (and without conducting any outside research), take a few minutes to answer the following questions:

An interactive H5P element has been excluded from this version of the text. You can view it online here:

https://openeducationalberta.ca/settlement/?p=1321\#h5p-37

- How did you arrive at your answers?

- Which questions did you find more difficult to answer? Why?

NOTE: Answers will not be revealed to learners for this pre-chapter activity. 


\section{A World in Crisis}

\section{Voluntary vs. Involuntary Migration}

Although there are similarities between the terms "immigrant" and "refugee," it is important to recognize that there are important distinctions as well. The Canadian Council for Refugees (n.d.) defines a refugee as a person who is forced to flee from persecution, whereas an immigrant is someone who has chosen to settle in another country. In other words, an immigrant is someone who migrates voluntarily and chooses to move elsewhere to pursue a better life, whereas a refugee is someone who is an involuntary migrant and moves because they have to in order to escape harm that is likely to befall them.

However, the distinction between voluntary and involuntary migration is not as clearcut as might first appear. For instance, the European University Institute (n.d.) argues that migration is very expensive because the cost of moving across international borders is high owing to the cost of travel, visa and immigration applications, time to do research on potential places to migrate to, and so on. In addition, newcomers often face significant financial hurdles upon arrival in their new communities, such as housing costs, fewer well-paying job prospects, and less-guaranteed social, financial, and/or emotional support from close family and friends.

Consequently, for many non-refugees, the "choice" to migrate may actually be made as a result of the harsh living and working conditions they encounter in their home countries. Although refugees cannot claim asylum in Canada directly to escape dire poverty (Government of Canada, 2021b), the link between extreme poverty and a negative quality of life is well-documented (Ontario Association of Children's Aid Societies, n.d.). Therefore, it could be argued that even though there may be an absence of immediate danger of persecution and/or death, the decision to migrate in such instances often is not really "voluntary."

Learning Activity 2: Voluntary vs. Involuntary Migration Case Studies 
INSTRUCTOR NOTE: These case studies are best worked through as in-class, small-group work in synchronous learning environments, but they can be modified to facilitate individualized and/or asynchronous learning, and groups can share their plans with their peers.

Examine each of the scenarios below and determine whether the individuals involved would be classified as "voluntary" or "involuntary" migrants. Why do you think so?

\section{- Case Study A: Ramona}

- Ramona is a single mother in Argentina. Nine months ago, her wife left to work in Mexico but has since not sent back any money. She has two young children aged three and six.

- She works as a waitress at a local restaurant, but the money she earns is barely enough to cover living expenses for herself and her children. She has since borrowed money from her friends and family to pay for an immigration consultant who would help her obtain a visitor visa to Canada.

- Once in Canada, she hopes to find work as a live-in maid through local Latin American diaspora communities.

- Case Study B: Emmanuel

- Emmanuel is a 40-year-old Haitian. He and his wife have a small shop. However, they have trouble covering all their monthly expenses.

- They have three children aged seven, nine, and twelve, and they live in a home that is not in good condition. They have been planning to change the flooring, roofing, and walls to keep the rain out of their home and keep it cooler during hot days.

- Emmanuel has decided to engage in temporary work in 
the agricultural sector in Ontario. Thus, for between four and six months a year, he moves to southern Ontario to work on different farms. When possible, he also takes additional work "under the table" in the construction or service industries to earn extra money.

- He sends almost all his remaining money "back home," and after five years, they have managed to make the necessary improvements to their house. However, while in Canada, Emmanuel has to endure very poor living conditions-he and the other temporary workers sleep in overcrowded dormitories, eat less food (so as to send more money back home), are frequently subjected to discriminatory comments by their bosses about "immigrants" and "people like them," and have experienced being cheated by employers who pay them less than they should have earned.

\section{- Case Study C: Mouna}

- Mouna is a 24 year-old woman currently living in Turkey. She is married and has a five-year-old daughter, and she and her husband had started a small clothing design business. However, most of it was destroyed by the latest earthquake that devastated their home community.

- The destruction of their business wiped out their modest savings, and the amount of financial aid they received from the Turkish government was not enough to allow them to rebuild. Furthermore, the destruction created by the earthquake decimated the local labour market, and as a result, work is difficult to find across the entire region.

- Upon attending a local government office, Mouna learned about the potential to find work in Canada as a live-in caregiver. She thought about relocating to 
Canada for the next two or three years to earn enough money to rebuild their business upon her return.

- Although it would be hard for her to leave her young family behind, Mouna explored her options. Although she could also find work in western Europe, the United States, and the Persian Gulf countries, she has relatives in Canada. She ultimately decided that her connections in Canada would give her the best chance for success abroad.

\section{The Global Refugee Crisis}

As noted above, the United Nations High Commissioner for Refugees (UNHCR) (2022b) estimates that by the middle of 2021, more than 84 million people had been forcibly displaced around the world (a number that includes 26.6 million refugees, 48.0 million internally displaced people, and 4.4 million asylum seekers). The number of people forcibly displaced in the world more than doubled between 2010 and 2020, and that number shows no signs of decreasing anytime soon (Library of Congress, 2021).

It's also important to recognize that more than two-thirds (68\%) of all refugees and displaced persons living abroad migrated from just five countries (Syria, Venezuela, Afghanistan, South Sudan, and Myanmar) (Almeida, 2022). More disturbingly, over 35 million forcibly displaced people were children under the age of 18, and between the years 2018 and 2020, approximately one million children were born as refugees (UNHCR, 2022b).

Furthermore, almost two-fifths (39\%) of all refugees are hosted in only five countries (Turkey, Colombia, Uganda, Pakistan, and Germany), and $73 \%$ of refugees and displaced persons living abroad are living in countries that border their countries of origin (UNHCR, 2022b). Interestingly, of the countries hosting the largest number of refugees, only Germany does not border one of the countries that has produced the largest numbers of refugees and displaced persons.

Moreover, the UNHCR (2022b) estimates that close to 127,000 refugees returned to their countries of origin during the first half of 2021, while an additional 16,300 were 
resettled in hosting countries. However, it must be noted that despite the fact that Canada has generally resettled more refugees than other countries in recent years (Canadian Press, 2019), Canada is not a country that hosts a large number of refugees relative to its population. Aruba, Lebanon, Curaçao, Jordan, and Turkey have been identified by Amnesty International (2019) as the countries that host the most refugees per capita in the entire world.

The severity (and escalation) of forced displacement has led leading humanitarian organizations from around the world to refer to the current state of affairs as a global refugee crisis (Catholic Agency for Overseas Development, 2022).

\section{The Climate Crisis of the Anthropocene}

The world as we know it is currently undergoing a very rapid shift in climate.

Although exact epochal boundaries are still subject to intense debate within the fields of climate science and geology, a new scientific consensus over the past two decades has emerged that suggests humanity has ushered in a new geological epoch on our planet-the Anthropocene (Alex, 2021).

This new epoch stands in stark contrast to the Holocene, which is the name given for the past 12,000 years. Whereas the Holocene marked the end of the global ice age and coincided with the rise of humanity as our planet's dominant species (Waggoner \& Smith, 2011), the Anthropocene emerged in the mid-20th century and is the period of time in which the actions of humanity are recognized as having an outsized influence on global climactic patterns (Lewis \& Maslin, 2015).

In short, the Anthropocene marks a period in Earth's geologic history where the rapid increases of carbon dioxide (a powerful greenhouse gas that traps heat from the sun that would have otherwise been radiated off of the Earth's surface), methane, and other gases in our atmosphere have significantly altered the natural fluctuations of the Earth's climate (and the weather that goes with it) (Denchak, 2019; Royal Society, 2022).

When discussing the Anthropocene, it is very important to distinguish between the concepts of climate and weather. Whereas weather refers to immediate and local atmospheric conditions (National Geographic, 2022), climate refers to the average long-term weather patterns of temperature and precipitation of a specific location (Climateurope, n.d.). For this reason, short-term instances of unseasonably cold weather in a particular region do not disprove the overall trend of an increase in the average global temperature. 
Adam (2008) argued that at no point in the past 650,000 years (and long before the emergence of humanity) has atmospheric carbon dioxide approached current concentrations. Unfortunately, that number surged to a level not seen in the last two million years at the start of the current decade (IPCC, 2021b, p. 8). As a result, there is no past comparison to use that might help us understand how the Earth's climate will respond to such rapid changes. However, the Sixth Assessment Report of the Intergovernmental Panel on Climate Change (IPCC, 2022) has offered clues into what the future likely holds for humanity on a rapidly warming planet.

When discussing changes to the Earth's climate, it's important to recognize that even seemingly small changes in the overall global temperature can have far-reaching consequences. Leading international climate scientists use global temperature records from 1850 to 1900 to determine average temperatures during pre-industrial times. By 2017 , the average global temperature had increased by $1^{\circ} \mathrm{C}$, and at the current pace of warming, a rise of $1.5^{\circ} \mathrm{C}$ (the limit to which much of the world agreed to by signing the Paris Agreement in 2015) would be reached by 2040 (IPCC, 2021a, p. 7).

Although it is true that the Earth goes through cyclical phases of global cooling and warming (USDA, n.d.), the staggering pace of global warming during the Anthropocene is a direct result of human activities that have altered natural cycles (Lee, 2020). In other words, as a result of large-scale industrialism, urbanization, and planet-wide transportation networks, humans have altered the chemical and biological makeup of our biosphere and have, in essence, created a new world for themselves, one far more inhospitable for human life (Hope, 2020, p. 123).

Furthermore, McCarthy (2021) explains how seemingly small increases in the average global temperature on our planet can have large consequences. A rise of just $1.5^{\circ} \mathrm{C}$, which could be temporarily achieved by as early as 2022-2026 (WMO, 2022) would result in a sea level rise of almost half a metre, an increase in the number of oceanic heat waves by a factor of 16 , and an increase of 19 extreme heat days per year. Landmasses would experience either a drastic increase in the intensity of rainfall or a doubling of the average drought, which would lead to increased habitat loss for plants and animals and a subsequent decrease in biodiversity and food production. These impacts become exponentially more pronounced if global warming rises by $2^{\circ} \mathrm{C}$ or more (Abnett, 2021).

\section{A Convergence of Crises}

As a result of the factors discussed above, our current reality requires us to more 
deeply explore how the global refugee and climate crises intersect and are now dialectically related.

Although beyond the scope of this particular chapter, a few words on dialectical materialism will allow us to establish the link between the global refugee and climate crises. Originating from the works of $\operatorname{Karl}$ Marx $(1857,1993)$, dialectical materialism refers to the interplay between humanity's thoughts, actions, experiences, and struggles. This interplay allows individuals to view the material (physical) conditions of their daily lives as the result of a productive (or creative) process, one that is intimately related to the construction of social, political, economic, and intellectual life in society (Chatterjee \& Ahmed, 2019, p. 370).

As such, important political and historical events arise as a result of the conflict between opposite social forces caused by humanity's basic material needs (Wambui, 2011). These conflicts are laid bare in relationships that feature great power imbalances such as those in advanced capitalist economies that have a colonialist view of humanity's relationship to the "natural world." Consequently, circumstances that produce economic exploitation and marginalization for large numbers of people and widespread environmental degradation are explicitly human creations (Chatterjee \& Ahmed, 2019, p. 373).

It could therefore be argued that the global refugee and climate crises are more intrinsically related than might appear at first glance, in no small part because, at their core, they are both products of contemporary human society. More importantly, there are other, more visible links between human migration and climate change.

For instance, the United Nations has estimated that between 200 million and 1 billion people could be displaced by 2050 (Lewis 2015). In addition, if the impacts of climate change occur in an exponential or non-linear fashion (for example, more rapid sea level rise and/or significant alterations to precipitation patterns), the potential for migration under duress is very high in many regions. In a worst-case scenario, billions of people worldwide could experience scarcity of food and/or water (McCarthy, 2021). Even the World Bank (2018) predicted that the climate crisis could exacerbate the global refugee crisis and create a much larger humanitarian crisis, one that threatens economic stability and development.

Unfortunately, current models are predicting that at the current rate of greenhouse gas emissions, these trends are likely to worsen. With each $1^{\circ} \mathrm{C}$ increase in temperature, the air's moisture-carrying capacity increases by $7 \%$, fuelling increasingly severe storms (Climate Signals, n.d.). Sea levels could rise by as much as one metre by the year 2100, submerging coastal areas and inhabited islands (Vaughn, 2019).

Pacific Islands nations are extremely vulnerable, as are more than 410 U.S. cities and others around the globe, including Vancouver, Osaka, Alexandria, Rio de Janeiro, 
Amsterdam, Shanghai, Lagos, Lisbon, and Mumbai (WMO, 2021; Holder, Kommenda, \& Watts, 2017). As well, rising temperatures could make parts of West Asia, Sub-Saharan Africa, and Latin America inhospitable to human life, with 700,000 people per year already being forcibly relocated by increasing desertification in Mexico alone (Azhar, 2017).

More recently, the Intergovernmental Panel on Climate Change's (2022) most recent update to its Sixth Assessment Report further argues that climate change is leading to increased food and water insecurity and a decline in agricultural productivity in many communities across Africa, Asia, and Latin America, as well as smaller island nations and circumpolar regions (IPCC, 2022, p. 12). Limiting the rise in global temperatures to $1.5^{\circ} \mathrm{C}$ would mitigate the harm experienced by people living in these ecological zones.

Nevertheless, the effects of the climate crisis have already begun to cascade into the global refugee crisis. For example, an increasing body of evidence suggests that $\underline{a}$ prolonged drought and a lack of access to fresh water and arable farmland may have been a major factor in triggering Syria's civil war and its resulting refugee crisis (Cramer, 2021). Furthermore, in 2020, there were 55 million people who were forcibly displaced by extreme weather, a number that represents the first time in recorded world history that the number of people whose lives were disrupted by climate change exceeded those disrupted by armed conflict (Lombrana, 2021).

As such, given the fact that human activities are solely responsible for the creation of the global refugee crisis, and that human activity has resulted in the climate crisis being experienced in the Anthropocene, it is apparent that these twin crises are dialectically related human creations. It is therefore imperative that solutions to these twin crises be similarly viewed in a mutually constitutive manner. The next section will discuss current national and international protocols and regulations governing human migration, the contexts in which they have been created and used to shape our understandings of forced displacement in our world, and how these protocols (and the theoretical and empirical understandings of human migration they inform) must be updated if they are to be reflective of the reality of life in the Anthropocene. 


\section{Protocols, Policies, and Regulations}

\section{International Protocols}

It is important to recognize that the Government of Canada is a signatory of every major international protocol pertaining to human migration over the past 75 years. While not every protocol is legally-binding, it is important to note that each represents a commitment made by the federal government to uphold standards it agreed to at the international level. For the purposes of this discussion, five particular accords will be examined.

\section{A. Universal Declaration of Human Rights (1948)}

The Universal Declaration of Human Rights is a historic document adopted by the United Nations General Assembly in December 1948 (three years after the end of the Second World War). It is an international (and legally binding) accord that has provided the foundational basis for human rights legislation the world over. It contains 30 articles that if universally applied, would provide basic dignity and security for all people worldwide.

Key provisions of the Universal Declaration of Human Rights include (but are not restricted to) the following:

- All human beings are born free and equal in dignity and rights. They are endowed with reason and conscience and should act towards one another in a spirit of solidarity (Article 1).

- Everyone has the right to life, liberty, and security of person (Article 3).

- No one shall be subjected to torture or to cruel, inhuman, or degrading treatment or punishment (Article 5).

- No one shall be subjected to arbitrary arrest, detention, or exile (Article 9).

- No one shall be subjected to arbitrary interference with their privacy, family, home, or correspondence, nor to attacks upon their honour or reputation (Article 12).

- Everyone has the right to freedom of movement and residence within the borders of each state. Everyone has the right to leave any country, including their own, and to return to their country (Article 13).

- Everyone has the right to freedom of thought, conscience, and religion (Article 
18).

- Everyone, as a member of society, has the right to social security and is entitled to realization of the economic, social, and cultural rights indispensable for their dignity and the free development of their personality (Article 22).

- Everyone has the right to work, to free choice of employment, favourable conditions of work and protection against unemployment, the right to equal pay for equal work, and the right to form and join trade unions (Article 23).

- Everyone has the right to a standard of living adequate for the health and wellbeing of themselves and their families, including food, clothing, housing, medical care, and social services (Article 25).

- Everyone has the right to education. Education shall be free, compulsory, and equally accessible to all on the basis of merit (Article 26).

\section{B. Convention on the Status of Refugees (1951) and Protocol Relating to the Status of Refugees (1967)}

The 1951 Convention on the Status of Refugees (otherwise known as the 1951 Refugee Convention) is a legally binding agreement that clarifies the rights of refugees and the obligations of all United Nations member states to assist with the support of refugees. It argues that states are responsible for protecting the fundamental human rights of their citizens, and that when they fail to do so, individuals suffer serious violations of their human rights.

The 1951 Convention is the first example of a legal definition of the terms migrant (defined as an individual who leaves their country for reasons other than persecution and enjoys the protections of their own government, even when they are abroad) and refugee (defined as a person who is outside their country of nationality or habitual residence and has a well-founded fear of being persecuted).

The 1951 Convention also specifies that a person may lose their status as a refugee if they return to their home country or become naturalized and permanently settle in a host country. Furthermore, an individuals may also lose their status as a refugee if they have committed war crimes, crimes against humanity, serious non-political crimes such as rape, murder, fraud, or embezzlement, or are found guilty of acts contrary to the purposes of the United Nations.

Key rights protected under the 1951 Convention include (but are not restricted to) the following:

- The right to access the courts (Article 16).

- The rights to employment (Article 17), housing (Article 21), public education 
(Article 22), and public relief (social assistance) (Article 23).

- The right to freedom of movement (Article 26).

- The right to be issued identity and travel documents (Article 28).

- The right to not be punished for illegal entry into the territory of a contracting (signatory) state (Article 31).

- The right to not be expelled except under strictly defined conditions (Article 32).

However, the key principle of the 1951 Convention is enshrined in Article 33-the right to non-refoulement. Non-refoulement refers to the right of a person to not be returned to a country where they face serious threats to their life or freedom.

In addition, in 1967, the Protocol Relating to the Status of Refugees was ratified to expand the scope of the 1951 Convention, which originally was only applied to individuals impacted by events that occurred before 1951, most of which were in Europe. The ratification of the 1967 Protocol thus extended the protections offered in the 1951 Convention to all individuals who were designated as refugees by the United Nations and the signatory states.

\section{Global Compact for Migration (2017)}

The 2017 Global Compact for Migration was the first intergovernmentally negotiated agreement to cover all dimensions of international migration in a holistic and comprehensive manner. Although it is not legally binding, it is an aspirational agreement grounded in the values of state sovereignty, responsibility sharing, nondiscrimination, human rights, and cooperation.

The Compact contains 23 different objectives for managing human migration at local, national, and international levels, and undertakes to do the following:

- Aims to mitigate the adverse drivers and structural factors that hinder people from building and maintaining sustainable livelihoods in their countries of origin

- Aims to reduce risks and vulnerabilities migrants face at different stages of migration by respecting, protecting, and fulfilling their human rights

- Seeks to address legitimate concerns of communities, while recognizing that societies are undergoing demographic, economic, social, and environmental changes

- Strives to create conditions that enable migrants to enrich societies through their human, economic, and social capacities

The key objectives of the Compact include, but are not restricted to, the following:

- Minimize the adverse drivers and structural factors that compel people to leave

400 | Protocols, Policies, and Regulations 
their country of origin (this includes natural disasters, the adverse effects of climate change, and environmental degradation) (Objective 2).

- Enhance the availability and flexibility of pathways for regular migration (this includes cooperating to identify, develop, and strengthening solutions for migrants compelled to leave their countries of origin because of natural disasters, the adverse effects of climate change, and environmental degradation) (Objective 5).

- Empower migrants and societies to realize full inclusion and social cohesion (Objective 16).

- Eliminate all forms of discrimination and promote evidence-based public discourse to shape perceptions of migration (Objective 17).

- Strengthen international cooperation and global partnerships for safe, orderly, and regular migration (Objective 23).

\section{Global Compact on Refugees (2018)}

The Global Compact on Refugees was ratified by the United Nations General Assembly in late 2018 and can best be thought of as an accord that fosters greater international cooperation between UN member states and is geared towards finding a solution to the global refugee crisis.

Billed as an opportunity to reimagine how refugees are supported in different countries, the four main objectives of the Compact are to do the following:

- Ease the pressures on host countries

- Enhance refugee self-reliance

- Expand access to third-country solutions

- Support conditions in countries of origin for a safe and dignified return

In addition, the Compact recognizes that environmental degradation, climate change, and natural disasters interact with (and add to) other existing refugee crises (UNHCR, 2018, p. 10). Instances of forced displacement because of climate and environmental events are explicitly identified as factors that need to be addressed in future international efforts aimed at addressing the global refugee crisis. 


\section{Environmental and Climate Refugees}

As discussed above, our planet's climate is rapidly warming, and this warming is having a widespread impact on global migration patterns. Consequently, increasing international attention has been paid to the plight of individuals forcibly displaced by rising sea levels, desertification, larger and more powerful storms, water and food scarcity, and environmental pollution (Brown, 2011).

\section{Defining Environmental and Climate Refugees}

At this point, it is useful to turn this discussion towards a more concrete definition of an environmental or climate refugee. El-Hinnawi (1985) defines environmental refugees as "those people who have been forced to leave their traditional habitat, temporarily or permanently, because of a marked environmental disruption (natural and/or triggered by people) that jeopardized their existence and/or seriously affected the quality of their lives (p. 4). In addition, Myers (2002) refers to environmental refugees as individuals who do not have the opportunity to provide for themselves and/or their families because of drought, soil erosion, desertification, deforestation, or other factors combined with pollution pressures and the extreme poverty found in their homelands. As a result of the poverty caused by environmental degradation, these people have no alternative but to attempt to seek sanctuary elsewhere (Myers, 1993, p. 752).

Burkett (2012) further refines this definition and conceives of an environmental or climate refugee as an individual displaced because of sudden or slow-onset climaterelated events. Sudden-onsetevents are extreme weather events such as hurricanes and tornadoes that cause an immediate threat to human life, whereas slowonsetevents occur over a much longer period of time and include climate events such as sea level rise and desertification. However, given the complex ways in which climate change can manifest itself, with slow-onset phenomena resulting in an increase in catastrophic sudden-onset phenomena, and given the pre-existing social and economic conditions in societies that are more vulnerable to the impacts of climate change, it has been difficult to establish a direct link between changing climate and the circumstances surrounding individual claims for asylum (Kraler, Cereni \& Noack, 2011).

To sum up, despite disagreements on the best terminology to use, and as discussed here, a broad consensus has emerged around the world that acknowledges how anthropogenic (human-induced) climate change is a major factor in current and 
future migration trends. As such, existing dominant theoretical and empirical understandings of human migration are not particularly transferable to envisaging how migration would unfold under the conditions of non-linear climatic change.

\section{The Legalities of Recognizing Environmental and Climate Refugees}

Further complicating this discussion is the existing legal discourse around the protection of refugees. The 1951 Refugee Convention and the 1967 Protocol Relating to the Status of Refugees were both proclaimed at a point in time when the effects of climate change were not felt as acutely as they are today.

In addition, those critical of referring to individuals displaced by climate change as climate refugees are worried that this will "[blur] the boundaries between the definition of refugees according to the 1951 Refugee Convention-'Convention refugees'-and popular concepts regarding refugees" (Apap, 2019, p. 5) and make it difficult to distinguish climate refugees from others affected by forced displacement (Apap, 2019, p. 5). Although it could be generally agreed upon that the effects of forced human displacement because of climate change could be similar to those experienced by "Convention refugees," a key distinction is that the right to non-refoulement (see the discussion above) implies that active persecution occurs. This is an important distinction-Convention refugees are granted legal protections under international law because they cannot rely on supports from the governments of the countries they are fleeing, whereas if they are fleeing as a result of climate change, their ability to rely on state resources in their countries of origin is still a possibility (Kälin \& Schrepfer, 2012, p. 32).

However, a recent ruling by the United Nations Human Rights Committee (UNHRC) has opened the door to re-examining this legal distinction. On January 21, 2020, the UNHRC issued a landmark ruling indicating that individuals seeking asylum in another country should not be deported to countries experiencing climate conditions that are incompatible with the right to life (OHCHR, 2020). This ruling was the culmination of a years-long struggle for refugee status launched by Ioane Teitiota, who originally migrated to New Zealand from Kiribati (Weiss, 2015).

Though Teitiota and his wife were simply seeking extensions to their visas, the arguments put forth in their defence-that deportation to Kiribati would place the family in imminent harm through their repatriation to a country widely believed to be the most at risk to permanently disappear under the seas of a rapidly-warming planet-were the first to suggest that existing global protocols governing the status 
of refugees could include migrants forced to relocate due to human-induced climate change (Iberdrola, 2022).

Unfortunately, it is important to note that the United Nations ruling only represented a partial victory for Teitiota. Although the ruling did provide nominal recognition for the existence of climate refugees, the UN also indicated that Teitiota's case did not meet the threshold for "imminent" risk for Convention refugees given that the full impact of rising sea levels might not be felt for at least a decade or more, and as a result, he was not granted official refugee status ( $\mathrm{Su}, 2020)$.

Ultimately, the outcome of this case should encourage policymakers, researchers, and settlement service providers to think more carefully about how climate change might upend conventional understanding of human migration. Keyes (2019) further argues that there is a duty for states to address a global harm principle and support individuals and groups affected by their actions. Similarly, Hush (2017) notes that other countries in the world have already moved to provide legal protections for persons forcibly displaced by environmental catastrophe. Specifically, asylum law in

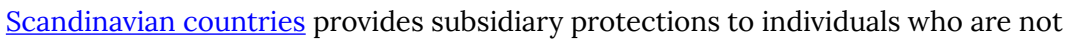
able to return to their countries of origin as a result of armed conflict or environmental degradation (Hush, 2017. For more information, please refer to the text of the Aliens Act in Finland.

The above discussion has illustrated the complexities surrounding the recognition and protection of environmental and climate refugees. Given the enormous political, legal, and logistical challenges of formally recognizing these refugees on an international level, it may be easier for individual nations to play a leading role in supporting those who are negatively impacted (and forcibly displaced) by climate change (Keyes, 2019, p. 25). In other words, nations could respond by creating new rules and regulations that complement and expand human rights and humanitarian protections for environmental and climate refugees within their own territories. In doing so, nations that take such action could inspire others to do the same.

Learning Activity 3: What should Canada's obligations to refugees be?

INSTRUCTOR NOTE (1): This activity would be optimal as a smallgroup activity in a synchronous learning environment but could also work as an individual reflective exercise for different modalities. 
INSTRUCTOR NOTE (2): This activity is designed to deconstruct an unfortunate and persistent myth in Canada-one about how the Government of Canada gives more financial help to refugees than it does to "Canadians" who retire here.

Watch the $\mathrm{CBC}$ News video How much do refugees and immigrants get in social assistance? and read the Government of Canada's response to persistent myths regarding the support offered to refugees in Canada. Take notes on key points made in these resources, and reflect on what you think Canada's obligations should be and why. In your reflection, take particular note of the international protocols that the Government of Canada has already signed. Should these obligations be extended to environmental and climate refugees? Why or why not?

INSTRUCTOR NOTE (1): This activity would be optimal as a smallgroup activity in a synchronous learning environment but could also work as an individual reflective exercise for different modalities.

Watch the video Environmental migrants: The neglected refugees and take notes on how the content of this video relates to past and present discussions on international protocols pertaining to the status of refugees. What are some of the similarities between our current understanding of refugees and the "environmental migrants" discussed in the video? What are some differences? What is the relevance of this discussion for settlement workers? 


\section{Recognizing Canada's Ecological and Humanitarian Obligations}

In this final section of the chapter, we will discuss Canada's current refugee program, how Canada has responded to recent waves of the global refugee crisis, and what, if anything, could and should be done by the Canadian government to support the growing numbers of environmental and climate refugees in the world.

\section{Canada's Immigrant and Refugee System}

In Canada, the Refugee and Humanitarian Resettlement Program applies to people who need protection from outside Canada, and the In-Canada Asylum Program is open to people making refugee claims from within Canada (Government of Canada, 2019).

For the Refugee and Humanitarian Resettlement Program, the United Nations, along with private sponsors, identifies refugees for resettlement. A person cannot apply directly into this program; they must be approved by the UN. Private sponsors are organizations who have signed agreements with the government of Canada to help with the settlement of refugees, and Groups of Five are groups of people who have come together to help refugees with the resettlement process.

For the In-Canada Asylum Program, individuals in Canada may be eligible to apply if they have a well-founded fear of persecution and/or are at risk of torture if they are deported. The Immigration and Refugee Board (IRB) is an independent board that oversees all refugee matters, and ultimately decides if a refugee's claim is accepted or not. Grounds for persecution that can render a person a refugee include the following:

- Race

- Religion

- Political opinion

- Nationality

- Being a part of a gender or sexual minority group

At the moment, the Government of Canada does not recognize climate or environmental refugees, so does not accept claims for asylum from individuals who are displaced by climate change and/or extreme weather events. Individuals who

406 | Recognizing Canada's Ecological and Humanitarian Obligations 
wish to immigrate to Canada must apply via other streams for admission to the country (Government of Canada, 2022c).

\section{Recognizing Canada's Ecological and Humanitarian Obligations}

The science around human-induced climate change has been settled, and Canada continues to exert a disproportionately large per-capita ecological footprint in the world (World Population Review, 2022). It may therefore be reasonable to suggest that the Government of Canada bears a responsibility to demonstrate global leadership in providing pathways to permanent residency via its refugee programs for individuals displaced by climate change.

Canada has the opportunity to play a pioneering role in adding climate-change based displacement to the criteria that the federal government uses to accept claims from asylum seekers. It could also use its considerable influence on the international stage to lobby for the inclusion of environmental and climate refugees to the 1951 Refugee Convention and 1967 Protocol Relating to the Status of Refugees.

Moreover, other scholars have argued that it is difficult for people to remain in their home countries if their traditional territories are no longer conducive to the right to life, while also noting that the term "migrant" does not sufficiently describe the plight of those who have involuntarily moved from their countries of origin (IPCC, 2021b). Using the term "migrant" has the added effect of focusing more on the resourcefulness of migrants and less on the reasons why individuals migrate in the first place (Akbar \& Preston, 2019, p. 15).

Furthermore, Canada is a signatory to the Paris Agreement. Enacted in 2016, the Agreement is a legally binding international treaty on climate change with the overall goal of reducing greenhouse-gas emissions as quickly as possible, thereby limiting the rise of global temperatures to $1.5^{\circ} \mathrm{C}$ above pre-industrial levels (UNFCCC, 2022). In order for signatories to meet their obligations, they must engage in broad-based economic and social transformations, with mechanisms in place for financial assistance for poorer countries and a commitment to share technological innovations that can help reduce greenhouse-gas emissions on a global scale. Despite these lofty ambitions, and a further commitment by the Canadian government to reduce its share of greenhouse-gas emissions at the COP26 Conference in 2021 (Government of Canada, 2021a; United Nations, n.d.a), Canada's response to the climate crisis has been underwhelming at best (Zimonjic, 2021).

As a result, the refusal to formally recognize climate change as grounds under which 
a person could apply for asylum would absolve countries like Canada from the responsibility it must bear for its part in contributing to a rapidly warming world. Such a refusal would further ensure that poorer countries, which are already feeling the effects of human-induced climate change more acutely, would continue to disproportionately face the consequences for our collective failure to adequately address climate change without having recourse to flee those consequences (McCarthy, 2020). This in and of itself could be seen as an act of persecution and is contrary to the global image of Canada as a multicultural country that is a worldleader in environmental protection.

\section{Canada's Most Recent Responses to Waves of the Global Refugee Crisis}

Although beyond the scope of this particular chapter, the Canadian government unfortunately has a long history of weaponizing immigration policy to restrict the flow of migrants from non-Western regions of the world (Caldararu, 2021). Although there have been some positive developments in Canada's responses to more recent waves of the global refugee crisis, the overall response from the government has been decidedly mixed. Consider the refugee situations described below.

\section{A. Syrian Refugees (2015-2021)}

The Syrian Civil War started in 2011 as a peaceful protest against the Syrian government by protesters angered by what they perceived to be authoritarian rule by the country's leadership (Encyclopaedia Britannica, 2022b). Inspired by the Arab Spring, a series of populist uprisings aimed at securing more political freedoms for people living in North African and Middle Eastern nations (Encyclopaedia Britannica, 2022a), the situation in Syria quickly degenerated into a tragic and brutal civil war. As of this writing, this war has displaced more than 13 million people and resulted in the deaths of over 500,000 others (BBC News, 2022).

Public opinion in support of refugees from Syria was galvanized following the widely publicized image of Aylan Kurdi, a three-year-old boy whose lifeless body was found washed up on a beach in Turkey after the boat he and his family were fleeing in capsized in the Mediterranean Sea (NPR, 2017). Many countries from around the world were moved to take action, and Canada in particular committed to taking in 25,000 refugees in 2015-16 (Government of Canada, 2022a); by 2021, more than 73,000 Syrian refugees had resettled in Canada (Kalata, 2021). 
At the same time, it's important to recognize that the reaction to the Canadian government's response was not universally positive. Many instances of Islamophobia were reported in Canada following the federal government's commitments to Syrian refugees, with petitions and public events decrying the alleged influx of "Muslims" into Canada, despite the fact that Syria itself is a very multi-ethnic nation with considerable religious diversity (Kanji, 2016). In addition, the government was also criticized for not developing the infrastructure needed to support Syrian refugees upon their arrival in Canada quickly enough and for creating a "two-tiered" refugee system that fast-tracked Syrian applicants at the expense of others (Molnar, 2017).

\section{B. Afghan Refugees (2021-Present)}

The situation in Afghanistan has also deteriorated in recent years, with a noted increase in the number of individuals fleeing the country as a result of the official withdrawal of the remaining military personnel from Western nations engaged in the country's occupation (Human Rights Watch, 2021). Canada, in particular, played a leading role in the invasion and occupation of Afghanistan, which was launched by the United States in retaliation for the events that occurred on September 11, 2001 and relied very heavily on the supports and assistance provided by local allies who acted as translators and interpreters for the Canadian military (Azzi \& Foot, 2009; History.com Editors, 2022).

Although the Canadian government has committed to resettle 40,000 refugees from Afghanistan as quickly as possible and has settled 11,300 as of this writing (Government of Canada, 2022d), the Canadian government has been accused of and heavily criticized for abandoning its Afghan allies in their most desperate hours of need (Debusmann Jr., 2022). In particular, the federal government's biometric requirements of Afghan refugees and refusal to fast-track applications for asylum for Afghans (Goodyear, 2022) stands in stark contrast to the approach taken to support refugees from Ukraine (Beauchemin \& Jones, 2022).

\section{Ukrainian Refugees (2022-Present)}

In early 2022, the Russian military launched a full-scale military invasion of neighbouring Ukraine (Center for Preventative Action, 2022). The result of the conflict has been the largest refugee crisis on European soil since the Second World War, with more than 5 million people having fled Ukraine (Vierlinger, 2022). As tragic as this latest refugee wave is, it is important to recognize that the response to the 
refugee crisis in Ukraine has been very different than the reaction to the refugees from Syria and Afghanistan.

On a global scale, Western media has been guilty of shocking instances of racist double-standards in their coverage of the conflict and of refugees themselves. For example, Polońska-Kimunguyi (2022) argues that although the ongoing conflict in Ukraine continues to dominate news headlines in Europe and North America, lesserknown conflicts in Yemen, Palestine, Somalia, and Ethiopia seem forgotten. Other major news networks went further, indicating their disbelief that such devastation could occur in "civilized" places such as Ukraine, as opposed to places like Iraq or Afghanistan that have seen conflict rage for decades, places where the victims look like any European family that could be one's neighbour (France 24, 2022; Lambert, 2022; Al Jazeera Staff, 2022).

These examples illustrate how refugees from Europe fleeing an aggressor who invaded their country are favourably described in other Western countries, whereas refugees from Africa, Asia, and the Middle East who are fleeing crises are seen as potential terrorists (Tahir, 2022).

Unfortunately, we see evidence of a similar type of bias in recent Canadian government policy towards refugees from Ukraine (Hwang, 2022). In response to the escalating conflict, the federal government quickly announced that an unlimited number of people fleeing the war in Ukraine will be eligible to apply for new temporary visa categories. These categories waive most of the processing and biometric requirements for applicants and make it easier for employers to hire Ukrainian refugees (Tasker, 2022; IRCC, 2022). The Government of Alberta went one step further, announcing detailed plans to assist Ukrainian refugees but remain decidedly non-committal to providing similar supports to refugees from other countries (Tran, 2022).

However, despite the divergent approaches to supporting refugees from different countries, the above examples demonstrate that when the political will is apparent, governments do have the capacity to make significant changes to existing refugee policy and to make those changes quickly. It is therefore reasonable to assume that the Canadian government has the ability to legally recognize the right for environmental and climate refugees to claim asylum in Canada.

Learning Activity 5: Test Your Knowledge 
INSTRUCTOR NOTE: Although this activity can work well as an individual activity followed by a large-group discussion, it could be combined with Learning Activity 1 in this chapter (where learners are asked to do the same quiz) and work well as an online discussion forum topic.

On your own, take a few minutes to revisit the questions asked of you at the beginning of this chapter. Take note of how your answers may have changed and what the significance of these changes may mean for your future professional practice as a settlement worker.

LEARNER NOTE: Compare and contrast your responses to the same set of questions that you were first asked in Learning Activity 1. How did your answers change?

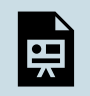

An interactive $\mathrm{H} 5 \mathrm{P}$ element has been excluded from this version of the text. You can view it online here:

https://openeducationalberta.ca/settlement/?p=1343\#h5p-38

Learning Activity 6: Leading By Example: Working Towards "Eco" Settlement Work (Part 1)

INSTRUCTOR NOTE: This activity would be optimal as a face-toface, think-pair-share activity but could be effective as a topic in an online discussion forum as well.

The enormity of the challenges presented by the global refugee and climate crises can feel overwhelming. Nevertheless, imagining 
potential solutions to these crises is well within the scope of what any one individual (or group of individuals) can do.

Settlement workers often play the role of advocates in their communities. Imagine that you have an opportunity to have a oneon-one conversation with the Prime Minister of Canada on the topics discussed in this unit. Create a list of five or six key questions that you would like to ask that are based on what you have learned in this chapter. What might responses to those questions be? How would you respond to those responses?

Learning Activity 7: Leading By Example: Working Towards "Eco" Settlement Work (Part 2)

INSTRUCTOR NOTE: This activity lends itself best to an in-person small-group breakout or think-pair-share but could also work in a synchronous online learning environment or as an individual reflection.

Take 10 minutes to think about how discussions on climate change and migration are important for effective settlement work. As you think about this, ask yourself the following questions:

- How is climate change disrupting our understanding of human migration?

- What must settlement workers do to address this new reality through their work?

- What must settlement workers do differently if they are to be effective at meeting the needs of environmental and climate refugees?

- How can the settlement sector in Canada play a leading role in advocating for environmental and climate refugees? 


\section{Concluding Remarks: The Role of Canada's Settlement Sector}

This chapter has explored the emergence of two defining crises that have emerged as the most important challenges facing humanity during the Anthropocene. Although they might appear to be separate phenomena at first glance, the global refugee crisis and climate crisis are in fact dialectically related. Both are the direct result of human activities, and each crisis exerts a major influence upon the other.

Through an understanding of the extent to which climate change can lead to weather extremes that disrupt food supplies and render entire territories inhospitable for human habitation, we can understand the similarities between the lived realities of persons displaced by environmental catastrophe and those currently afforded legal protection as "refugees" under international law.

In addition, through an understanding of the various international accords and protocols ratified by the Government of Canada, we can understand that Canada has an obligation to discuss the plight of environmental and climate refugees on the international stage. And as demonstrated by its responses to recent waves in the global refugee crisis, the Government of Canada does have the capacity to enact significant changes to refugee policy in this country (and to do so quickly) when it has the will.

As settlement workers, the need to have these discussions could not be more timely or urgent. As more individuals continue to be displaced by extreme weather events than by armed conflict, we must be cognizant of the need to sharpen our own analyses and adapt our own advocacy efforts to reflect the new reality of human migration in a world that has increasingly become "too hot to handle."

Learning Activity 8: End-of-Chapter Quiz

INSTRUCTOR NOTE: This activity can also serve as a marked assessment at the discretion of the instructor. 
An interactive H5P element has been excluded from this

version of the text. You can view it online here:

https://openeducationalberta.ca/settlement/?p=1345\#h5p-36 


\section{Chapter References and Attributions}

\section{References}

Abdullah, A. (2022, April 13). The 10 largest refugee crises to follow in 2022. Concern Worldwide U. S. https://www.concernusa.org/story/largest-refugee-crises/

Abnett, K. (2021, November 9). Explainer: What's the difference between $1.5^{\circ} \mathrm{C}$ and $2^{\circ} \mathrm{C}$ degrees of global warming? Reuters. https://www.reuters.com/business/cop/ whats-difference-between-15c-2c-globalwarming-2021-11-07/\#: :text=Warming\%20of\%201.5\%C2\%B0C,for\%20their\%20fo od\%20and\%20livelihoods

Adam, D. (2008, May 13). World carbon dioxide levels highest for 650,000 years, says US report. The Guardian. https://www.theguardian.com/environment/2008/may/ $\underline{13 / \text { carbonemissions.climatechange }}$

Akbar, M., \& Preston, V. (2019). Migration and resilience: Exploring the stock of knowledge. Social Sciences and Humanities Research Council of Canada. https://bmrc-irmu.info.yorku.ca/files/2020/06/Immigrants-and-ResilienceWorking-Paper Final new7.pdf?x15611

Al Jazeera Staff. (2022, February 27). 'Double standards': Western coverage of Ukraine war criticised. Al Jazeera News. https://www.aljazeera.com/news/2022/2/27/ western-media-coverage-ukraine-russia-invasion-criticism

Alex, B. (2021, June 19). The human epoch: When did the Anthropocene begin? Discover Magazine. https://www.discovermagazine.com/environment/the-human-epochwhen-did-the-anthropocene-begin

Almeida, T. (2022, April 6). The most urgent refugee crises around the world. World Vision. https://www.worldvision.ca/stories/refugees/refugee-crises-around-theworld

Amnesty International. (2022). The world's refugees in numbers. https://www.amnesty.org/en/what-we-do/refugees-asylum-seekers-andmigrants/global-refugee-crisis-statistics-and-facts/

Apap, J. (2019). The concept of 'climate refugee' - Towards a possible definition. European Parliamentary Research Service.https://www.europarl.europa.eu/RegData/ etudes/BRIE/2018/621893/EPRS_BRI(2018)621893_EN.pdf 
Azhar, G. S. (2017, December 18). Climate change will displace millions in coming decades. Nations should prepare now to help them. The Conversation. https://theconversation.com/climate-change-will-displace-millions-in-comingdecades-nations-should-prepare-now-to-help-them-89274

Azzi, S., \& Foot, R. (2021). Canada and the war in Afghanistan. The Canadian Encyclopedia. https://www.thecanadianencyclopedia.ca/en/article/internationalcampaign-against-terrorism-inafghanistan?gclid=CjwKCAjwyryUBhBSEiwAGN5OCJ1rLzoBCzkV3zY9utSeVaMQclC b9N7BDyfV5UnkPZRqAna2ZHIPRoCu6AQAvD BwE

Bates, D. C. (2002). Environmental refugees? Clarifying human migrations caused by environmental change. Population and Environment, 23(5), 465-477. http://gambusia.zo.ncsu.edu/readings/Bates2002PopEnv.pdf

BBC News. (2022, March 15). Why has the Syrian war lasted 11 years? https://www.bbc.com/news/world-middle-east-35806229

Beauchemin, G., \& Jones, A. M. (2022, May 3). Some Afghan refugees settling into life in Canada, but others still stranded. CTV News. https://www.ctvnews.ca/canada/ some-afghan-refugees-settling-into-life-in-canada-but-others-stillstranded-1.5885939

Brown, L. R. (2011). World on the edge: How to prevent environmental and economic collapse. Earth Policy Institute. https://www.earth-policy.org/images/uploads/ book files/wotebook.pdf

Bures, E. (2020, August 1). When everything is a crisis, nothing is. Foreign Policy. https://foreignpolicy.com/2020/08/01/when-everything-is-a-crisis-nothing-is/

Burkett, M. (2012). Climate refugees. In S. Alam, M. Bhuiyan, T. Chowdhury \& E. Techera (Eds.), Routledge handbook of international law (pp. 717-729). Routledge.

Caldararu, A. (2021). Social justice in settlement work. In O. Vergara, S. Oswald, A. Caldararu, L. Sutankayo, W. Ilott, R. Dela Cruz, \& W. Chambers (Eds.), Canadian settlement in action: History and future (pp. 75-136). NorQuest College.

Canadian Council for Refugees (CCR). (n.d.). Talking about refugees and immigrants: A glossary of terms. https://ccrweb.ca/sites/ccrweb.ca/files/static-files/ glossary.PDF

The Canadian Encyclopedia. (2022). Collection: Second World War. https://www.thecanadianencyclopedia.ca/en/collection/second-world-war

Canadian Press. (2019, June 20). Canada resettlement more refugees than any other 
country in 2018, UN says. CBC News. https://www.cbc.ca/news/politics/canadaresettled-most-refugees-un-1.5182621

Catholic Agency for Overseas Development (CAFOD). (2022, April 26). Refugee crisis explained. https://cafod.org.uk/News/International-news/Refugee-crisis-Q-A

CBC News. (2017, October 25). How much do refugees and immigrants get in social assistance? [Video file]. YouTube. https://www.youtube.com/watch?v=13aml32ujw0

Center for Preventative Action. (2022, September 12). Conflict in Ukraine. Council on Foreign Relations..https://www.cfr.org/global-conflict-tracker/conflict/conflictukraine

Chatterjee, I., \& Ahmed, W. (2019). Dialectical materialism: Marx's method in human geography? ACME: An International Journal for Critical Geographies, 18(2), 364-393. https://acme-journal.org/index.php/acme/article/view/1637/1466 available under a $\underline{\mathrm{CC} B Y-N C-N D}$ licence.

Climateurope. (n.d.). What is climate? What is climate change? https://www.climateurope.eu/what-is-climate-and-climate-change/

Climate Signals. (n.d.). Atmospheric moisture increase. https://www.climatesignals.org/climate-signals/atmospheric-moisture-increase

Cole, D. (2017, January 13). Study: What was the impact of the iconic photo of the Syrian boy? NPR News. https://www.npr.org/sections/goatsandsoda/2017/01/13/ 509650251/study-what-was-the-impact-of-the-iconic-photo-of-the-syrian-boy

Cook, J., Oreskes, N., Doran, P. T., Anderegg, W. R. L., Verheggen, B., Maibach, E. W., Carlton, J. S., Lewandowsky, S., Skuce, A. G., \& Green, S. A. (2016). Consensus on consensus: a synthesis of consensus estimates on human-caused global warming. Environmental Research Letters, 11(4), 1-7. https://iopscience.iop.org/article/ $10.1088 / 1748-9326 / 11 / 4 / 048002 / p d f$

Cramer, L. (2021). 1.3 The effects of climate change on the Syrian uprising. In K. Clark, T. Shaul, \& B. Lower (Eds.), Environmental ScienceBites. School of Environment and Natural Resources, Ohio State University. https://ohiostate.pressbooks.pub/ sciencebites/chapter/the-effects-of-climate-change-on-the-syrian-uprising/

David Suzuki Foundation. (2022). What is climate change? https://davidsuzuki.org/ what-you-can-do/what-is-climatechange/\#: :text=Climate\%20change\%20is\%20the\%20result,most\%20urgent\%20p roblem\%20we\%20face.

Debusmann Jr., B. (2022, May 11). Afghan interpreters fear families 'forgotten' by Canada. BBC News. https://www.bbc.com/news/world-us-canada-61251228 
Denchak, M. (2019, July 16). Greenhouse effect 101. Natural Resources Defense Council (NRDC).

https://www.nrdc.org/stories/greenhouseeffect-101\#: :text=Bednarski\%20for\%20NRDC-

What\%20Are\%20Greenhouse\%20Gases\%3F,gases\%20(which\%20are\%20synthetic)

El-Hinnawi, E. (1985). Environmental refugees. United Nations Environmental Programme. https://digitallibrary.un.org/record/121267? ln=en

Encyclopaedia Britannica. (2022a). Arab Spring pro-democracy protests. https://www.britannica.com/event/Arab-Spring

Encyclopaedia Britannica. (2022b). Syrian civil war. https://www.britannica.com/ event/Syrian-Civil-War/Civil-war

European University Institute. (n.d.). What is the difference between forced and voluntary migration? FutureLearn. https://www.futurelearn.com/info/courses/ migration-facts/0/steps/34214

Everbridge. (n.d.). Crisis emergency vs. routine emergency. https://www.everbridge.com/blog/crisis-emergency-vs-routine-emergency/

Facing History and Ourselves Collective. (n.d.). Understanding the global refugee crisis. Facing History and Ourselves Publications.

France 24. (2022, March 1). Arabs decry 'racist' double standard in Ukraine media commentary. https://www.france24.com/en/live-news/20220301-arabs-decryracist-double-standard-in-ukraine-media-commentary

France 24 English. (2015, July 7). Environmental migrants: The neglected refugees [Video file]. YouTube. https://www.youtube.com/watch?v=PbNe64DfyfY

Goodyear, S. (2022, April 19). This veterans group says it can no longer help people get out of Afghanistan [Transcript of radio broadcast]. CBC Radio: As It Happens: The Tuesday Edition. https://www.cbc.ca/radio/asithappens/as-it-happens-thetuesday-edition-1.6423423/this-veterans-group-says-it-can-no-longer-helppeople-get-out-of-afghanistan-1.6423615

Government of Canada. (2022a). Canada's response to the conflict in Syria. https://www.international.gc.ca/world-monde/issues_developmentenjeux_developpement/response_conflict-reponse_conflits/crisis-crises/ conflict_syria-syrie.aspx?lang=eng

Government of Canada. (2022b). Immigration and citizenship: Do government-assisted refugees get more income support and benefits than Canadian pensioners do? https://www.cic.gc.ca/english/helpcentre/answer.asp?qnum=105\&top=11

Government of Canada. (2022c). Immigration and citizenship: Immigrate to Canada. 
https://www.canada.ca/en/immigration-refugees-citizenship/services/ immigrate-canada.html

Government of Canada. (2022d). Immigration and citizenship: Refugees and asylum: Welcome Afghans. https://www.canada.ca/en/immigration-refugees-citizenship/ services/refugees/afghanistan.html

Government of Canada. (2021a). Environment and natural resources: UN climate change conference: Canada's achievements at COP26. https://www.canada.ca/en/services/ environment/weather/climatechange/canada-international-action/un-climatechange-conference/cop26-summit/achievements-at-cop26.html

Government of Canada. (2021b). Immigration and citizenship: Refugees and asylum. https://www.canada.ca/en/immigration-refugees-citizenship/services/ refugees.html

Government of Canada. (2019). Immigration and citizenship: How Canada's refugee system works. https://www.canada.ca/en/immigration-refugees-citizenship/ services/refugees/canada-role.html

Government of Finland. (n.d.). Aliens Act (trans. from Finnish).https://finlex.fi/en/ laki/kaannokset/2004/en20040301.pdf

Guterres, A. (2019, September 23). Remarks at 2019 Climate Action Summit. United Nations Secretary-General. https://www.un.org/sg/en/content/sg/speeches/ 2019-09-23/remarks-2019-climate-action-summit

History.com Editors. (2022). September 11 attacks. History Channel. https://www.history.com/topics/21st-century/9-11-attacks

Holder, J., Kommenda, N., \& Watts, J. (2017, November 03). The three-degree world: the cities that will be drowned by global warming. The Guardian. https://www.theguardian.com/cities/ng-interactive/2017/nov/03/three-degreeworld-cities-drowned-global-warming

Hope, W. (2020). The Anthropocene, global capitalism, and the crisis of futurity. New Zealand Sociology, 35(2), 121-141.

Human Rights Watch. (2021, September 9). What's next for Afghans fleeing the Taliban? https://www.hrw.org/news/2021/09/09/whats-next-afghans-fleeing-taliban

Hush, E. (2017, September 07). Developing a European model of international protection for environmentally-displaced persons: Lessons from Finland and Sweden. Columbia Journal of European Law. http://cjel.law.columbia.edu/ preliminary-reference/2017/developing-a-european-model-of-international- 
protection-for-environmentally-displaced-persons-lessons-from-finland-andsweden/

Hwang, P. K. S. (2022, June 22). Other newcomers forgotten as eyes remain on Ukraine, say advocates. CBC News. https://www.cbc.ca/news/canada/ottawa/newcomersrefugees-settle-ottawa-ukraine-afghanistan-support-1.6496103

Iberdrola. (2022). Kiribati, the first country rising sea levels will swallow up as a result of climate change. https://www.iberdrola.com/sustainability/kiribati-climatechange\#: :text=Kiribati\%2C\%20the\%20first\%20country\%20rising,for\%20islands\% 20and\%20coastal\%20regions

Immigration and Refugee Board (IRB) of Canada. (2022). Home page. https://irb.gc.ca/ en/Pages/index.aspx

Immigration, Refugees and Citizenship Canada (IRCC). (2022, March 3). Canada to welcome those fleeing the war in Ukraine [News release]. Government of Canada. https://www.canada.ca/en/immigration-refugees-citizenship/news/2022/03/ canada-to-welcome-those-fleeing-the-war-in-ukraine.html

Intergovernmental Panel on Climate Change (IPCC). (2022). Sixth assessment report. https://www.ipcc.ch/assessment-report/ar6/

Intergovernmental Panel on Climate Change (IPCC). (2021a). Frequently asked questions. In S. Connors \& R. Pidcock (Eds.), Climate change 2021: The physical science basis (pp. 3-32). Contribution of Working Group I to the Sixth Assessment Report of the Intergovernmental Panel on Climate Change. Cambridge University Press. $\quad$ https://www.ipcc.ch/site/assets/uploads/sites/2/2018/12/ $\underline{\text { SR15 FAQ Low Res.pdf }}$

Intergovernmental Panel on Climate Change (IPCC). (2021b). Summary for policymakers. In V. Masson-Delmotte, P. Zhai, A. Pirani, S. L. Connors, C. Péan, S. Berger, N. Caud, Y. Chen, L. Goldfarb, M. I. Gomis, M. Huang, K. Leitzell, E. Lonnoy, J. B. R. Matthews, T. K. Maycock, T. Waterfield, O. Yelekçi, R. Yu, \& B. Zhou (Eds.), Climate change 2021: The physical science basis (pp. 3-32). Contribution of Working Group I to the Sixth Assessment Report of the Intergovernmental Panel on Climate Change. Cambridge University Press. https://www.ipcc.ch/report/ar6/ wg1/downloads/report/IPCC AR6 WGI SPM.pdf

Kalata, N. (2021, March 15). Syrian refugees reflect on a decade of war and their new lives in the Toronto area. CBC News. https://www.cbc.ca/news/canada/toronto/ syrian-refugees-reflect-on-a-decade-of-war-and-their-new-lives-in-the-toronto$\underline{\text { area- }-1.5947946}$

Kälin, W., \& Schrepfer, N. (2012). Protecting people crossing borders in the context of climate change normative gaps and possible approaches. United Nations High 
Commissioner for Refugees Legal and Protection Policy Research Series. https://www.refworld.org/docid/4f38a9422.html

Kanji, A. (2016, May 2). We need to change the questions we ask about Muslims. The Star. https://www.thestar.com/opinion/commentary/2016/05/02/we-needto-change-the-questions-we-ask-about-muslims.html

Keyes, E. (2019). Environmental refugees? Rethinking what's in a name. North Carolina Journal of International Law, 44(3), 461-486. https://scholarship.law.unc.edu/cgi/ viewcontent.cgi?article $=2058 \&$ context $=$ ncilj

Kinzler, R. (n.d.). When and how did the ice age end? Could another one start? American Museum of Natural History. https://www.amnh.org/explore/ology/earth/ask-ascientist-about-our-environment/how-did-the-ice-age-end

Kraler, A., Cernei, T., \& Noack, M. (2011). "Climate refugees": Legal and policy responses to environmentally induced migration. European Union Directorate General for Internal Policies. https://www.europarl.europa.eu/RegData/etudes/etudes/join/ 2011/462422/IPOL-LIBE_ET(2011)462422_EN.pdf

Lambert, H. (2022, February 26). CBS reporter calls Ukraine 'relatively civilized' as opposed to Iraq and Afghanistan, outrage ensues. The Wrap. https://www.thewrap.com/cbs-charlie-dagata-backlash-ukraine-civilized/

Lee, H. (2020, July 21). How Earth's climate changes naturally (and why things are different now). Quanta Magazine. https://www.quantamagazine.org/how-earthsclimate-changes-naturally-and-why-things-are-different-now-20200721/

Lewis, R. (2015, December 02). Climate change already affecting migration patterns around the world. Al Jazeera America. http://america.aljazeera.com/articles/2015/ $\underline{12 / 2 / \text { climate-change-impacting-migration-patterns.html }}$

Lewis, S. L., \& Maslin, M. A. (2015). Defining the Anthropocene. Nature, 519, 171-180. https://doi.org/10.1038/nature14258

Library of Congress. (2021, June 28). International: Record number of people forcibly displaced in 2020. https://www.loc.gov/item/global-legal-monitor/2021-06-28/ international-record-number-of-people-forcibly-displaced-in-2020/

Lombrana, L. M. (2021, May 25). In 2020, more people displaced by extreme climate than conflict. Al Jazeera News. https://www.aljazeera.com/economy/2021/5/25/ bbin-2020-more-people-displaced-by-extreme-climate-than-conflict

Marx, K. (1993). Grundrisse: Foundations of a critique of political economy (M. Nicolaus, Trans.). Penguin Classics. (Original published in 1857.)

McCarthy, J. (2021, July 30). Climate crisis: What's the difference between a rise of 
1.5, 2, and 3 degrees Celsius? Global Citizen. https://www.globalcitizen.org/en/ content/the-difference-in-global-warming-levelsexplained/?gclid=EAIaIQobChMI1_6NzqLv9wIVhRmtBh1FSwlIEAAYAyAAEgJuaPD_ BwE

Military Wiki. (n.d.). Military occupation. Fandom Lifestyle Community. https://military-history.fandom.com/wiki/Military occupation

Molnar, P. (2017). Canadian response to the Syrian refugee crisis. The Canadian Encyclopedia. https://www.thecanadianencyclopedia.ca/en/article/canadianresponse-to-the-syrian-refugee-crisis

Mukheibir, P., \& Mallam, P. (2019, September 30). Climate crisis - what's it good for? The Fifth Estate. https://thefifthestate.com.au/urbanism/climate-change-news/ climate-crisis-whats-it-good-for/

Myers, N. (2002). Environmental refugees: a growing phenomenon of the 21st century. Philosophical Transactions of the Royal Society B: Biological Sciences, 357(1420), 609-613. $\quad$ https://www.ncbi.nlm.nih.gov/pmc/articles/PMC1692964/pdf/ 12028796.pdf

Myers, N. (1993). Environmental refugees in a globally warmed world: Estimating the scope of what could well become a prominent international phenomenon. BioScience, 43(11), 752-761. https://doi.org/10.2307/1312319

National Geographic. (2022). Weather. https://education.nationalgeographic.org/ resource/resource-library-weather

National Public Radio (NPR). (2022). Special series: Ukraine invasion - explained. https://www.npr.org/series/1082539802/russia-ukraine-invasion-explained

North American Space Agency (NASA). (2022). Scientific consensus: Earth's climate is warming. https://climate.nasa.gov/scientific-consensus/

Ontario Association of Children's Aid Societies (OACAS). (n.d.). Poverty and child welfare: Effects of poverty on families. https://oacas.libguides.com/ c.php?g=702168\&p=4992460

Phelps, R. (2019, November 14). Leadership in times of crisis. Disaster Recovery Journal. https://drj.com/journal main/leadership-in-times-of-crisis/

Połońska-Kimunguyi, P. (2022, May 10). War, resistance and refuge: Racism and double standards in Western media coverage of Ukraine. London School of Economics Department of Media and Communications. https://blogs.lse.ac.uk/medialse/ 2022/05/10/war-resistance-and-refuge-racism-and-double-standards-inwestern-media-coverage-of-ukraine/ 
The Royal Society. (2022). The basics of climate change. https://royalsociety.org/ topics-policy/projects/climate-change-evidence-causes/basics-of-climatechange/

Smith, D., \& Waggoner, B. M. (2011). The Holocene epoch. International Commission on Stratigraphy. https://ucmp.berkeley.edu/quaternary/ holocene.php\#: :text=The\%20Holocene\%20is\%20the\%20name,the\%20Holocene\% 20has\%20been\%20a

Souissi, T. (2021). Islamophobia in Canada. The Canadian Encyclopedia. https://www.thecanadianencyclopedia.ca/en/article/Islamophobia

$\mathrm{Su}$, Y. (2020, January 29). UN ruling on climate refugees could be gamechanger for climate action. Climate Home News. https://www.climatechangenews.com/2020/ $\underline{01 / 29 / \text { un-ruling-climate-refugees-gamechanger-climate-action/ }}$

Tahir, A. F. (2022, August 26). Selective empathy: Western media's horrific double standards amid Russia-Ukraine war. Al Hakam Weekly. https://www.alhakam.org/ selective-empathy-western-medias-horrific-double-standards-amid-russiaukraine-war/

Tasker, J. P. (2022, March 3). Canada prepared to welcome an 'unlimited number' of Ukrainians fleeing war, minister says.CBC News. https://www.cbc.ca/news/ politics/canada-unlimited-number-ukrainians-1.6371288

Tran, P. (2022, April 20). Alberta government committed to helping Ukrainians, but mum on other refugees.Global News. https://globalnews.ca/news/8772385/ alberta-government-ukraine-refugee-support/

United Nations. (2022). Universal Declaration of Human Rights (UDHR). (Originally published in 1948.) https://www.un.org/en/about-us/universal-declaration-ofhuman-rights

United Nations. (2017). Global Compact for Migration. https://refugeesmigrants.un.org/migration-compact

United Nations. (n.d.a). Climate action: COP26: Together for our planet. https://www.un.org/en/climatechange/cop26

United Nations. (n.d.b). The climate crisis - A race we can win. https://www.un.org/ en/un75/climate-crisis-race-we-can-win

United Nations Framework Convention on Climate Change (UNFCCC). (2022). The Paris Agreement. https://unfccc.int/process-and-meetings/the-paris-agreement/ the-paris-agreement 
United Nations High Commissioner for Refugees (UNHCR). (2022a). The 1951 Refugee Convention. https://www.unhcr.org/1951-refugee-convention.html

United Nations High Commissioner for Refugees (UNHCR). (2022b). Refugee data finder. https://www.unhcr.org/refugee-statistics/

United Nations High Commissioner for Refugees (UNHCR). (2018). The Global Compact on Refugees. https://www.unhcr.org/the-global-compact-on-refugees.html

United Nations High Commissioner for Refugees (UNHCR). (1967). 5. Protocol Relating to the Status of Refugees. https://www.unhcr.org/5d9ed66a4

United Nations Office of the High Commissioner for Human Rights (OHCHR). (2020, January 21). Historic UN human rights case opens door to climate change asylum claims. https://www.ohchr.org/en/press-releases/2020/01/historic-un-humanrights-case-opens-door-climate-change-asylum-claims?LangID=E\&NewsID=25482

United States Department of Agriculture (USDA). (n.d.). Natural climate cycles. https://www.fs.usda.gov/ccrc/education/climate-primer/natural-climate-cycles

Vaughan, A. (2019, September 25). IPCC report: Sea levels could be a metre higher by 2100. New Scientist Magazine. https://www.newscientist.com/article/2217611-ipccreport-sea-levels-could-be-a-metre-higher-by-2100/

Vierlinger, J. (2022, April 20). UN: Ukraine's refugee crisis is Europe's biggest since WWII. Atlantic Council. https://www.atlanticcouncil.org/blogs/ukrainealert/un-ukrainerefugee-crisis-is-europes-biggest-since-wwii/

Waggoner, B. M., \& Smith, D. (2011). The Holocene epoch. UC Museum of Anthropology - Berkeley. https://ucmp.berkeley.edu/quaternary/holocene.php

Wamubi, M. W. (2011). Dialectical materialism and historical dialectics of Karl Marx [Unpublished manuscript]. University of Nairobi. https://www.grin.com/ document/703506

Weiss, K. R. (2015, January 28). The making of a climate refugee. Foreign Policy. https://foreignpolicy.com/2015/01/28/the-making-of-a-climate-refugeekiribati-tarawa-teitiota/

The World Bank. (2018, March 19). Climate change could force over 140 million to migrate within countries by 2050: World Bank Report. https://www.worldbank.org/ en/news/press-release/2018/03/19/climate-change-could-forceover-140-million-to-migrate-within-countries-by-2050-world-bank-report

World Meteorological Organization (WMO). (2022, May 9). WMO update: 50:50 chance of global temperature temporarily reaching $1.5^{\circ} \mathrm{C}$ threshold in next five years. 
https://public.wmo.int/en/media/press-release/wmo-update-5050-chance-ofglobal-temperature-temporarily-reaching-15\%C2\%B0c-threshold

World Meteorological Organization (WMO). (2021, November 10). Climate change increases threats in South West Pacific. https://public.wmo.int/en/media/pressrelease/climate-change-increases-threats-south-west-pacific

World Population Review. (2022). Ecological footprint by country 2022. https://worldpopulationreview.com/country-rankings/ecological-footprint-bycountry

Zimonjic, P. (2021, November 25). Canada's climate change efforts going from 'failure to failure,' says commissioner's report.CBC News. https://www.cbc.ca/news/politics/ environment-commissioner-report-failure-to-failure-1.6262523 